\title{
Różne oblicza Azji - między Azją Wschodnią a Indiami
}

\author{
Redakcja naukowa \\ Joanna Marszałek-Kawa \\ Marcin Górnikiewicz
}




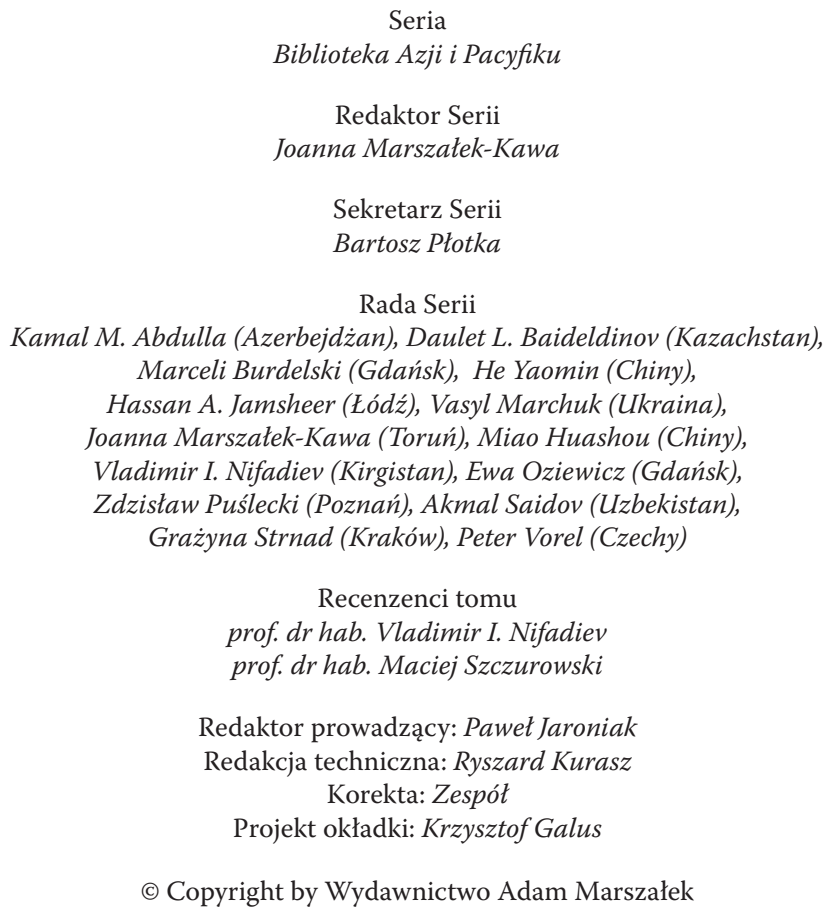

Wszystkie prawa zastrzeżone. Książka, którą nabyłeś, jest dziełem twórcy i wydawcy. Żadna jej część nie może być reprodukowana jakimkolwiek sposobem - mechanicznie, elektronicznie, drogą fotokopii itp. - bez pisemnego zezwolenia wydawcy. Jeśli cytujesz fragmenty tej książki, nie zmieniaj ich treści i koniecznie zaznacz, czyje to dzieło

\section{Toruń 2020}

ISBN 978-83-8180-308-3

Publikacja dofinansowana przez Wydział Bezpieczeństwa, Logistyki i Zarządzania WAT

Wydawnictwo prowadzi sprzedaż wysyłkową:

tel./fax 566485070 , marketing@marszalek.com.pl

Wydawnictwo Adam Marszałek, ul. Lubicka 44, 87-100 Toruń

tel. 5666422 35, 5666081 60, e-mail: info@marszalek.com.pl, www.marszalek.com.pl

Drukarnia, ul. Warszawska 54, 87-148 Łysomice, tel. 566783478 


\section{Spis treści}

Wstęp

Janusz Mariański

Współczesna modernizacja społeczna a religia

(ze szczególnym uwzględnieniem Korei Południowej)

\section{Kazimierz Pierzchała}

Edukacja wielokulturowości i międzykulturowości na płaszczyźnie wzajemnych wpływów Azji i reszty świata .... 43

\section{Anna Brzezińska-Rybicka}

Edukacja w systemie penitencjarnym Azji na przykładzie wybranych państw 64

\section{Mirosława Cylkowska-Nowak}

Rozwój psychologii szkolnej w Japonii

\section{Elżbieta Ceholnik-Szafran}

Podobieństwa i różnice między polskim a japońskim systemem edukacji

\section{Karolina Kalita}

„Ie" - japońska rodzina tradycyjna, jej struktura i funkcje ..... 109 


\section{Andrzej Woźniak}

Laogai - chiński sposób na resocjalizację więźnia przez pracę

Dorota Kamińska-Jones, Agnieszka S. Staszczyk

Świątynia jako nośnik nacjonalistycznych treści wizerunki bohaterów narodowych w indyjskiej architekturze sakralnej z I. poł. XX w.

\section{Aleksandra Kobylańska}

Tradycyjna dieta azjatycka w kontekście uwarunkowań pedagogiki społecznej

\section{Renata Gałaj-Dempniak}

Problem marnowania żywności w Japonii 


\section{Wstęp}

Azja Wschodnia mimo upływu lat i intensyfikacji wzajemnych relacji z Europą nadal cieszy się nimbem swoiście pojmowanej egzotyczności. Na tle całego kontynentu azjatyckiego stanowi wyjątkowy obszar, który charakteryzuje się własną specyfiką wobec pozostałych narodów i kultur Azji Północnej, Centralnej, Południowej, a nawet nieco bliższej mentalnie Azji Południowo-Wschodniej. Wszystkie prezentowane teksty - poza jednym dotyczą tego szczególnego obszaru. Ostatnia praca ze względu na swój wyjątkowy walor poznawczy i niezwykłą aktualność prezentowanych treści w kontekście obecnej sytuacji międzynarodowej również została ujęta przez redakcję, która na wzór wytrawnego kucharza, chcącego nadać potrawie szczególnego aromatu, dodaje szczyptę specjalnie przygotowanej przyprawy.

Autorzy niniejszej monografii zaprezentowali wycinek tej różnorodnej i niezwykle złożonej wewnętrznie mieszanki etniczno-wyznaniowej. Nie jest oczywiście możliwe, aby w 200-stronicowej publikacji zaprezentować pełne spektrum dające choćby zbliżone wyobrażenie o prezentowanych kulturach i nacjach. W zamian autorzy zaoferowali możliwość spojrzenia przez przysłowiowe „szkiełko" na wybrane fragmenty badanych i prezentowanych obszarów codzienności. Janusz Mariański przybliżył czytelnikom południowokoreański punkt widzenia na ewolucję społeczno-religijną. Kazimierz Pierzchała zaoferował możliwość zagłębienia się w złożony świat edukacji wielokulturowej w odniesieniu do relacji zachodzących między Azją a pozostałymi kontynentami. Z kolei Anna Brzezińska-Rybicka poświęciła swoje badania niezwykle wciągającej i nadal mało znanej problematyce edukacji w systemie penitencjarnym Azji na tle wybranych 
państw. Możliwość znacznie głębszego zanurzenia się w meandry różnic mentalnych zaoferowała Mirosława Cylkowska-Nowak, prezentując ewolucję psychologii szkolnej w Kraju Kwitnącej Wiśni. Japonia stała się również obiektem badań Elżbiety CeholnikSzafran, która skoncentrowała wysiłek poznawczy na podobieństwach i różnicach zachodzących pomiędzy polskim i japońskim systemem edukacji. Karolina Kalita przybliżyła z kolei polskim czytelnikom tradycyjnie postrzeganą strukturę i funkcje pełnione w japońskim społeczeństwie przez rodzinę. Andrzej Woźniak natomiast poruszył złożony i wywołujący wiele emocji temat laogai, czyli chińskich obozów pracy, jako formułę mającą w założeniu twórców sprzyjać resocjalizacji więźnia poprzez pracę. Renata Gałaj-Dempniak podążyła w zupełnie odmiennym kierunku, skupiając się na ukazaniu czytelnikom problemu marnowania żywności we współczesnej Japonii, a dla kontrastu Aleksandra Kobylańska poświęciła swoje badania korelacjom zachodzącym między dietą azjatycką a pedagogiką społeczną. Dorota Kamińska-Jones w duecie z Agnieszką S. Staszczyk skoncentrowały swój obszar zainteresowań na indyjskiej architekturze sakralnej jako nośniku nacjonalistycznych treści poprzez prezentowanie wizerunków indyjskich bohaterów narodowych.

Niniejsza monografia stanowi zbiór tekstów, które przede wszystkim pozwalają czytelnikowi zagłębić się w tak często pomijane detale życia codziennego nacji zamieszkujących kontynent azjatycki. Prezentowana pozycja znajdzie zatem sympatyków zarówno wśród pasjonatów Azji, jak i czytelników poszukujących nowości i nowinek o życiu innych kultur. Bez wątpienia czas poświęcony na lekturę nie będzie stracony, a wręcz przeciwnie może stać się inspiracją do dalszych poszukiwań.

Inspiracji i miłej lektury.

Joanna Marszałek-Kawa Marcin Górnikiewicz 


\author{
Janusz Mariański \\ Wyższa Szkoła Nauk Społecznych z siedzibą w Lublinie \\ ORCID ID: https://orcid.org/0000-0002-0620-8000
}

\title{
Współczesna modernizacja społeczna a religia (ze szczególnym uwzględnieniem Korei Południowej)
}

Najogólniej modernizację można określić jako „zbliżanie się społeczeństwa w sposób zamierzony, celowy, planowany do uznanego modelu nowoczesności, najczęściej do wzorca jakiegoś istniejącego społeczeństwa uznanego za najbardziej rozwinięte"1. Jest to powolne przezwyciężanie zapóźnienia w stosunku do tego modelu, powolne dochodzenie do tego wzorca. Rozwój ten przechodzi typowe stadia: od społeczeństwa tradycyjnego, w którym dominują tendencje zachowawcze, instancje rodzinne, przypisane formy statusu społecznego, fatalistyczny pogląd na świat; poprzez formy pośrednie; do społeczeństwa nowoczesnego, które charakteryzuje gotowość do zmiany, dominacja więzi zawodowych i pozarodzinnych, uzyskiwanie statusu społecznego poprzez własne osiągnięcia, innowacyjność, przedsiębiorczość, orientacja ku przyszłości, racjonalny pogląd na świat ${ }^{2}$.

Podstawowe założenia teorii modernizacji zostały wypracowane w socjologii zachodniej w latach 50. XX w. Modernizacja jako proces unowocześniania może być rozumiana na trzy sposoby: „1) upowszechnienie różnorodnych innowa-

\footnotetext{
1 P. Sztompka, Socjologia. Analiza społeczeństwa, Kraków 2012, s. 583.

2 Ibidem, s. 565-566.
} 
cji techniczno-technologicznych - zakłada się tu, że zmiany w technice powodują zmiany społeczne; 2) wszelkie zmiany (nie tylko technologiczne) prowadzące do nowocześniejszych i doskonalszych form organizacji danego społeczeństwa, jego gospodarki, polityki, kultury; 3) przekształcenie społeczeństwa typu tradycyjnego w społeczeństwo <nowoczesne>, utożsamiane zazwyczaj z społeczeństwem przemysłowym"3.

Wyróżnia się kilka płaszczyzn, na których dokonuje się proces modernizacji: a) na płaszczyźnie ekonomicznej - eliminacja gospodarki naturalnej na rzecz gospodarki pieniężnej, powstawanie jednostek produkcyjnych zorientowanych na rynek; b) w sferze politycznej - rozwój struktur władzy; c) na płaszczyźnie społecznej - zmiany ról społecznych, przekształcenia instytucji i ich funkcji, przemiany struktur społecznych, zmiany w obrębie rodziny i więzi pokrewieństwa; d) na płaszczyźnie kulturowej - wzrastające zróżnicowanie systemów religijnych, światopoglądowych, wzrost roli nauki, zmiany obyczajowe, kształtowanie nowych stylów życia; e) w sferze psychiki indywidualnej - wzrost podatności na zmiany, racjonalne tłumaczenie świata, pojawienie się pragnienia osiągnięć $c^{4}$. Wymienia się jeszcze modernizację ekologiczną, która oznacza wzrost i rozwój gospodarczy dzięki strategiom uwzględniającym potrzeby ochrony środowiska (rozwój gospodarczy i ochrona środowiska nie wykluczają się) $)^{5}$.

Według Neil J. Smelsera cechą podstawową modernizacji jest zróżnicowanie strukturalne, czyli ustanowienie bardziej wyspecjalizowanych i autonomicznych jednostek społecznych, zróżnicowanie mechanizmów regulacyjnych we wszystkich sfe-

3 A. Słaboń, Modernizacja, [w:] M. Pacholski, A. Słaboń, Słownik pojęć socjologicznych, Kraków 2010, s. 123.

4 Ibidem, s. 123.

5 A. Giddens (współpraca P.W. Sutton), Socjologia, tłum. O. Siara, A. Szulżycka, P. Tomanek, Warszawa 2012, s. 1081. 
rach życia, zróżnicowanie się systemów wartości i społecznej stratyfikacji, zróżnicowanie się czynności rodzinnych. W wyniku modernizacji stary ład ulega dezaktualizacji, integracja nabiera nowego charakteru. Procesy te nie przebiegają jednakowo, zaznacza się pluralizm dróg rozwojowych w różnych państwach czy regionach. Różnice te dotyczą warunków poprzedzających modernizację, dynamiki zmian, dróg modernizacji, zwłaszcza na etapach zaawansowanej modernizacji, wystąpienia dramatycznych wydarzeń w okresie modernizacji, np. wojny, rewolucje, klęski żywiołowe. Różnorodne doświadczenia narodowe warunkują odmienność form uniwersalnych cech procesów modernizacji ${ }^{6}$.

Od samego początku swego istnienia socjologia wiązała pozycję i rolę religii w społeczeństwie z procesami modernizacji. Wielu socjologów było przekonanych, że w wyniku procesów modernizacyjnych (zmiany cywilizacyjne, zmiany w strukturze społecznej, kultura masowa, nowe formy spędzania czasu wolnego, komercja i konsumpcja) następują zmiany sekularyzacyjne prowadzące do osłabienia, a nawet zanikania religii w życiu społecznym ${ }^{7}$. W ramach teorii modernizacji społecznej lansowano tezę o sekularyzacji, czyli o stopniowym zanikaniu religijności wiążącej się z warunkami tradycyjnymi odchodzącymi w przeszłość. „Odczarowanie świata”, jak to określał Max Weber, wiązało się z trzema procesami: a) z procesem racjonalizacji, czyli dominującej roli rozumu, nauki i argumentów empirycznych; b) z procesem zróżnicowania strukturalnego i funkcjonalnego prowadzącego do oddzielenia Kościoła, obrzędów i wiary od codziennego życia; c) zanik znaczenia religii

6 N.J. Smelser, Przyczynek do teorii modernizacja, [w:] Elementy teorii socjologicznych. Materiały do dziejów współczesnej socjologii zachodniej, red. W. Derczyński, A. Jasińska-Kania, J. Szacki, Warszawa 1975, s. 324-326.

7 M. Wohlrab-Sahr, Religion, [w:] Lexikon Soziologie und Sozialtheorie. Hundert Grundbegriffe, red. S. Farzin, S. Jordan, P. Reclam jun., Stuttgart 2008, s. 238-241. 
wiąże się z modernizacją cywilizacyjną i zmianami struktury społecznej, przede wszystkim z masową kulturą, z atrakcyjnymi formami spędzania czasu wolnego, komercją i konsumpcją ${ }^{8}$.

Sekularyzacja jako zjawisko społeczne była i jest wyjaśniana głównie poprzez procesy modernizacji. Wskazywano także na takie przyczyny, jak industrializacja i urbanizacja, dyferencjacja społeczna, rozwój techniczny i ekonomiczny, rozpad tradycyjnych środowisk społecznych, pluralizm społeczno -kulturowy, rozwój nauki, procesy racjonalizacji, liberalizacja stosunków Kościół - państwo. Modernizacja społeczna oddziaływała z reguły negatywnie na religię i jej znaczenie w społeczeństwie, na atrakcyjność wspólnot religijnych, niosła ze sobą efekty sekularyzacyjne. W sytuacjach, w których ludziom żyje się coraz lepiej, trudniej jest im koncentrować się na tym, co przyjdzie w przyszłości („po tamtej stronie”). Niekiedy ujmowano wpływ modernizacji jako jednokierunkowy i nieodwracalny. Religię i religijność pojmowano jako zmienną zależną, poddaną wpływom wielu czynników społecznych i ekonomicznych, określanych terminem zbiorczym jako modernizacja społeczna.

Dzisiaj nie przyjmuje się już bezdyskusyjnie, że modernizacja nieuchronnie towarzyszy zeświecczeniu (sekularyzacji) społeczeństw. Piotr Sztompka podkreśla, że wiele z formułowanych dawniej diagnoz i wyprowadzanych z nich prognoz nie sprawdziło się. „Obserwujemy nie tylko trwałość religii w epoce późnej nowoczesności, ale jej rozprzestrzenianie się zarówno w postaci tradycyjnej, w ramach wielkich religii, jak również w wielu nowych formach. »Nowa ewangelizacją« w chrześcijaństwie, fundamentalizm czy integryzm islamu, a równocześnie siła ruchów ekumenicznych akcentujących duchowość ponad podziałami religijnymi, zapełnianie się starych kościo-

8 P. Sztompka, Socjologia. Analiza społeczeństwa, Kraków 2012, s. $372-$ -373 . 
łów, a równocześnie wyłanianie się nowych zjawisk i ruchów parareligijnych określanych mianem New Age, kariera religii Wschodu w krajach zachodnich - to wszystko fenomeny i tendencje wskazujące raczej na postępującą sakralizację niż seku-

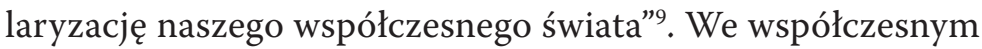
świecie jest wiele przykładów sakralizacji życia i nowych form fundamentalizmu religijnego ${ }^{10}$.

Za socjologiem niemieckim Detlefem Pollackem można opisywać - z socjologicznego punktu widzenia - modernizację społeczną na pięciu płaszczyznach: wzrostu dobrobytu materialnego, dyferencjacji funkcjonalnej, indywidualizacji, pluralizmu społeczno-kulturowego, rozszerzenia horyzontów wiedzy i doświadczenia oraz określać jej zróżnicowany wpływ na religijność współczesną ${ }^{11}$. W ramach tylko trzech płaszczyzn będziemy analizować związki pomiędzy modernizacją społeczną (nowoczesnością) i religijnością współczesną, najpierw na płaszczyźnie teoretycznej (ogólnej), a następnie na przykładzie Korei Południowej (płaszczyzna empiryczna).

Modernizacja społeczna nie musi prowadzić do coraz bardziej skutecznego usuwania religii z przestrzeni publicznej, aż do jej całkowitego wygaszenia. Trzeba się liczyć z pewnymi zahamowaniami czy nawet odwróceniem procesów sekularyzacyjnych, z ich zwrotami czy załamaniami. Sekularyzacja wydawała się w warunkach modernizacji społecznej (nowoczesność, ponowoczesność) czymś nieuchronnym i do pewnego stopnia automatycznym. Procesy desekularyzacji, indywidualizacji i pluralizacji religijnej oraz nowej duchowości zmuszają

9 Ibidem s. 373.

10 Idem, Socjologia zmian społecznych, tłum. J. Konieczny, Kraków 2005, s. 135.

11 D. Pollack, Religion und Moderne. Versuch einer Bestimmung ihres Verhältnisses, [w:] Gottesrede in postsäkularer Kultur, red. P. Walter, Freiburg im Breisgau 2007, s. 30-52. 
do rewizji globalnej tezy sekularyzacyjnej. Niektórzy socjologowie nie mówią już o teoriach, lecz o pewnych narracjach (opowieściach), które wykorzystuje się do tego, by nadać sens przemianom w religijności współczesnej.

\section{Modernizacja jako dobrobyt materialny a religia}

Filozof kanadyjski Charles Taylor mówi o świeckiej epoce i o społeczeństwie postchrześcijańskim w odniesieniu do Europy Zachodniej. Sekularyzacja czy zeświecczenie oznacza: a) rozdzielenie państwa od Kościoła i zanikanie religii w przestrzeni publicznej; b) zanikanie wiary i praktyk religijnych, ludzie odwracają się od Boga i przestają chodzić od kościoła; c) przejście od społeczeństwa, w którym wiara była niekwestionowana i nieproblematyczna, do społeczeństwa, w którym wiara w Boga jest tylko jedną z opcji, często nie najważniejszą, opcją wymagającą wielu poświęceń. Wiara w Boga nie jest aksjomatyczna, istnieje inna możliwość, także wybór doczesności pozbawionej wszelkiego religijnego wymiaru. We współczesnych społeczeństwach zachodnich tzw. samowystarczalny humanizm staje się powszechnie dostępną opcją. W swojej skrajnej formie nie akceptuje on żadnych innych celów poza pomyślnością doczesną i szczęściem człowieka. Samowystarczalny humanizm leży u podłoża nowoczesnej świeckości ${ }^{12}$.

Twierdzi się, że poziom społeczno-ekonomiczny społeczeństwa wpływa na postawy ludzi wobec religii i Kościoła. W państwach wysoko rozwiniętych pod względem gospodarczym, ze stabilnymi demokratycznymi strukturami politycznymi i rozbudowanym systemem socjalnym, obserwuje się mały udział osób regularnie uczęszczających do miejsc kultu,

12 Ch. Taylor, Świecka epoka. Dlaczego porzucamy religii, „Dziennik” 2007, nr 287, s. 12-13. 
wysoki zaś jest udział osób określających się jako indyferentne religijnie lub areligijne. Religia zyskała na znaczeniu w tych państwach, w których przed przełomem i po przełomie politycznym panowała trudna sytuacja gospodarcza i społeczna ${ }^{13}$.

Nowoczesny człowiek uczy się kontrolować naturalne i społeczne wpływy środowiska, zapobiegać różnego rodzaju ryzykom, jakie niesie ze sobą cywilizacja współczesna. Z tych różnych uwarunkowań wynikają konsekwencje dla religii. Można tu postawić dwie konkurencyjne hipotezy. Pierwsza sprowadza się do tego, że w miarę wzrostu dobrobytu oraz możliwości kontroli społeczeństwa i otaczającej go natury obniża się potrzeba religijnego zabezpieczenia i redukuje się poczucie przygodności, ponieważ człowiek współczesny nie czuje się już tak bezradny jak dawniej wobec niekorzystnych zjawisk naturalnych i społecznych. Druga hipoteza podkreśla, że w miarę zagwarantowania wyższego poziomu materialnego i zaspokojenia indywidualnych interesów, następuje przejście od wartości materialnych do wartości postmaterialnych, związanych z pytaniem o sens życia, dotyczących samorealizacji, partycypacji politycznej, doświadczenia przyjaźni i życiowych radości, co z kolei może prowadzić do otwartości na nowe wartości religijne. To, co było dawniej tylko przywilejem określonych warstw społecznych czy jednostek, staje się ogólnie dostępne ${ }^{14}$.

Tezę o sekularyzacji opartej na bezpieczeństwie egzystencjalnym podtrzymują Pippa Norris i Ronald Inglehart. Wycho-

13 O. Müller, Pomiędzy sekularyzacją a rewitalizacją. Przynależność do Kościoła i religijność w Europie Środkowej $i$ Wschodniej. Analiza porównawcza rozwoju od 1989/1990 roku, [w:] Pomiędzy sekularyzacja i religijnym ożywieniem. Podobieństwa i różnice w przemianach religijnych $w$ Polsce $i$ wiemczech, red. E. Firlit, M. Hainz, M. Libiszowska-Żółtkowska, G. Pickel, D. Pollack, Kraków 2012, s. 101-102.

14 D. Pollack, Religion und Moderne. Versuch einer Bestimmung ihres Verhältnisses, [w:] Gottesrede in postsäkularer Kultur, red. P. Walter, Freiburg im Breisgau 2007, s. 30-32. 
dzą oni z założenia, że bogate i biedne społeczeństwa na całym świecie różnią się wyraźnie pod względem stopnia rozwoju bezpieczeństwa dla środowiska i nierówności społeczno-ekonomicznych, co pociąga za sobą różnice w podstawowych warunkach życia oraz związanych z nimi poczuciem bezpieczeństwa i narażenia się na różnego rodzaju zagrożenia. Dorastanie w bezpiecznych warunkach w okresie kształtującym osobowość determinuje zapotrzebowanie na religię. Decyduje o tym, jak ważne dla ludzi są wartości religijne. Przyjmują ci socjologowie hipotezę, że osoby dorastające w mniej bezpiecznych warunkach będą przywiązywać większą wagę do wartości religijnych, dla osób mających większe poczucie bezpieczeństwa znaczenie wartości religijnych będzie mniejsze. Proces rozwoju społecznego wywiera znaczący wpływ na religijność. Przekształcanie się społeczeństw rolniczych w społeczeństwa przemysłowe, a nawet postprzemysłowe, i towarzyszący temu wzrost bezpieczeństwa, ogólnie osłabia znaczenie wartości religijnych ${ }^{15}$.

W społeczeństwach postindustrialnych coraz mniej osób uważa, że tradycyjne wartości duchowe, wierzenia i praktyki religijne odgrywają zasadniczą rolę w ich życiu i w życiu społeczeństwa. Stają się oni coraz bardziej obojętni wobec tradycyjnych przywódców i instytucji religijnych, tracą chęć uczestniczenia w życiu kultowym. Zapotrzebowanie na religię jest zróżnicowane jako wynikające z podstawowych warunków życia, jakich doświadczają ludzie w społeczeństwach bogatych i biednych. „Ludzie żyjący w stresie potrzebują surowych, możliwych do przewidzenia reguł. Muszą mieć pewność odnośnie tego, co nastąpi, ponieważ znajdują się w niebezpieczeństwie - ich margines błędu jest wąski i potrzeba im

15 P. Norris, R. Inglehart, Sacrum i profanum. Religia i polityka na świecie, red. R. Babińska, Kraków, 2006 s. 41-47; J. Baniak, Religia katolicka i Kościót rzymskokatolicki w opiniach polskiej mtodzieży. Od akceptacji do kontestacji, Kraków 2015. 
maksymalnej przewidywalności. W przeciwieństwie do nich osoby dorastające w warunkach względnego bezpieczeństwa są w stanie tolerować więcej wieloznaczności i odczuwają mniejszą potrzebę posiadania absolutnych, ścisłych i jasnych reguł oficjalnie przyjętych przez religię. Ludzie posiadający stosunkowo duże poczucie bezpieczeństwa egzystencjalnego potrafią zaakceptować odstępstwa od znanych reguł łatwiej niż osoby niemające pewności, czy ich podstawowe potrzeby egzystencjalne zostaną zaspokojone"16. Te wszystkie procesy nie muszą oznaczać tego, że w miarę rozwoju gospodarczego społeczeństw religia zanika pod każdą postacią, jej pozostałości i symboliczne elementy często istnieją nawet wtedy, gdy dla deklarujących formalną przynależność wyznaniową treść religii traci na znaczeniu. Obok czynników ekonomicznych ważną rolę odgrywa także kontekst historyczny i specyfika kulturowa.

Sondaże międzynarodowe zrealizowane przez Ronalda Ingleharta wydają się potwierdzać pozytywny związek pomiędzy modernizacją społeczną i sekularyzacją. Do takiego wniosku dochodzi także Aleksandra Jasińska-Kania, według której wyniki badań europejskich i światowych systemów wartości do pewnego stopnia potwierdzają przewidywania teorii modernizacji i przemian ponowoczesnych. Najwyższy poziom wartości świecko-racjonalnych i postmaterialistyczno-indywidualistycznych występuje w państwach o najwyższym poziomie rozwoju społeczno-gospodarczego, jak Szwecja, Norwegia, Dania, Holandia, Niemcy, Finlandia, Szwajcaria, Austria, Francja i Belgia. Niezależnie od poziomu rozwoju gospodarczego, bogactwa i modernizacji wpływ na konfigurację wartości w poszczególnych państwach wywierają różnice regionalne odmienności tradycji kulturowych (w tym przede wszystkim religijnych) oraz doświadczeń historycznych związanych z podziałami politycz-

16 Ibidem, s. 48. 
nymi i ustrojowymi. Na przykład w państwach protestanckich znacznie częściej niż w katolickich przyjmowane są wartości indywidualistyczne, świecko-racjonalistyczne i postmaterialistyczne, a także otwartość kulturowa i tolerancja oraz postawy permisyjne przywalające na odchylanie się od norm w sferze życia prywatnego, seksu i relacji interpersonalnych ${ }^{17}$.

Analizy statystyczno-korelacyjne przeprowadzone przez Detlefa Pollacka wydają się potwierdzać tę tezę. W państwach zachodnioeuropejskich po drugiej wojnie światowej wzrost dobrobytu nie sprzyjał religii i Kościołom chrześcijańskim. Zmniejszały się wskaźniki formalnej przynależności do Kościołów i innych wspólnot religijnych, obniżał się poziom praktyk i wierzeń religijnych. Wzrost w ostatnich dwóch dekadach tzw. religijności pozakościelnej (np. ezoteryzm, okultyzm, spirytyzm, nowa duchowość) nie kompensuje strat, jakie ponoszą w Europie Zachodniej Kościoły chrześcijańskie. Spadek poziomu religijności w ostatnich czterdziestu latach może być - zdaniem Pollacka - przynajmniej częściowo wyjaśniony procesami modernizacji. Jeżeli nawet nie jesteśmy w stanie bezspornie udowodnić wpływu modernizacji społecznej na sekularyzację, to przynajmniej możemy twierdzić, że oddziałuje ona raczej negatywnie na witalność religii ${ }^{18}$. Procesy modernizacyjne sprzyjają jednak pojawianiu się nowych opcji alternatywnych jako konkurencyjnych wobec tradycyjnych religii i Kościołów ${ }^{19}$.

Jeżeli nawet wzrost dobrobytu ludzi w nowoczesnych społeczeństwach nie sprzyja religijności, to w mniejszym stopniu

17 A. Jasińska-Kania, Zmiany wartości Polaków a procesy transformacji, europeizacji i globalizacji, [w:] Wartości i zmiany. Przemiany postaw Polaków w jednoczacej się Europie, red. eadem, Warszawa 2012, s. 336.

18 D. Pollack, Religion und Moderne. Versuch einer Bestimmung ihres Verhältnisses, [w:] Gottesrede in postsäkularer Kultur, red. P. Walter, Freiburg im Breisgau 2007, s. 47-49.

19 G. Pickel, Religionsmonitor verstehen was verbindet. Religiosität im internationalen Vergleich, red. Bertelsmann Stiftung, Gütersloh 2013, s. 20. 
odnosi się to do pozakościelnych form religijności. Wpływ modernizacji na różne formy pozakościelnej religijności i New Age wydaje się dość ograniczony. Takie wskaźniki modernizacji, jak wyższe wykształcenie, wyższy status społeczny, mają co najwyżej nieznaczny negatywny wpływ, a niekiedy tego wpływu nie wywierają. Młodsze roczniki badanych Europejczyków skłaniają się ku religijności pozakościelnej silniej niż roczniki starsze. Ponieważ liczba zwolenników religijności pozakościelnej jest stosunkowo mała w społeczeństwie, nie może ona w wyraźny sposób opóźnić dominującego trendu sekularyzacyjnego. Z drugiej strony występuje zjawisko określane przez niektórych socjologów jako dyspersja religii, która pojawia się w nowych formach w różnych dziedzinach życia świeckiego, w których tradycyjne religie i Kościoły były już nieobecne ${ }^{20}$.

Wielu socjologów podtrzymuje tezę, że odchodzenie od wiary i Kościoła wiąże się ze współczesnymi warunkami życia. Bezwyznaniowość wzrasta szczególnie szybko wśród ludzi dobrze wykształconych i w środowiskach wielkomiejskich, religijność utrzymuje się zaś w regionach zacofanych ekonomicznie ${ }^{21}$. Przynależność do Kościoła koreluje wyraźnie z czynnikami ekonomicznymi, ale i w społeczeństwach nowoczesnych religie i Kościoły nie są bez szans. Według Franza-Xavera Kaufmanna dobrowolna asceza chrześcijańska w społeczeństwach nadmiaru mogłaby stać się znakiem religijnym o szczególnej wartości ${ }^{22}$. Jeżeli nawet zgodnie z teorią modernizacji społecznej, a zwłaszcza ze wzrostem ekonomicznego dobrobytu, religia w Europie

20 W. Gebhardt, Believing without Belonging? Religiöse Individualisierung und neue Formen religiöser Vergemeinschaftung, [w:] Gottesrede in postsäkularer Kultur, red. P. Walter, Freiburg im Breisgau 2007, s. 301-302.

21 E.S. Hasse, Christliche Säkularität. Was glauben die Hamburger?, „Materialdienst. Zeitschrift für Religions- und Weltanschauungfragen” 2013, nr 7, s. 250-255.

22 F.-X. Kaufmann, Czy chrześcijaństwo przetrwa? tłum. U. Poprawska, Kraków 2004, s. 152. 
Zachodniej straciła na znaczeniu i coraz mniej ludzi odwołuje się do norm religijnych jako uzasadniających ich życiową praxis, to Europa mimo tych dokonujących się procesów sekularystycznych nie jest sekularna. Wciąż większość Europejczyków uważa religię za coś ważnego lub średnio ważnego w ich życiu. Europa jest religijna i sekularna zarazem. Wpływ modernizacji społecznej na religijność poza Europą wymagałby odrębnego omówienia. Nie jest on z pewnością tak wyraźny, jak w społeczeństwach zachodnioeuropejskich.

\section{Modernizacja jako zróżnicowanie społeczne a religia}

Ważna cecha nowoczesnych społeczeństw dotyczy dyferencjacji funkcjonalnej, która oznacza usamodzielnianie się poszczególnych dziedzin życia społecznego jak gospodarka, polityka, prawo, nauka, medycyna, wychowanie, a nawet moralność i religia. Mają one swoje własne sposoby działania i punkty widzenia w funkcjonowaniu codziennym, posługują się własnymi kodami działania. To, co w poszczególnych systemach częściowych (subsystemy) uchodzi za znaczące (relewantne), nie zależy wprost od innych subsystemów, które mają swoje własne wartości, kryteria i struktury. Jeżeli nawet poszczególne subsystemy społeczne są między sobą w relacji będącej swoistym strukturalnym połączeniem, to nie narusza to podstawowej autonomii subsystemów. Autonomia musi być zachowana, jest ona podstawowym warunkiem ich wzajemnych relacji ${ }^{23}$.

Niektórzy socjologowie określają w ogóle sekularyzację jako proces dyferencjacji społecznej, która „oznacza w swej treści usamodzielnienie się sfery religii i równoczesne uwolnienie in-

23 D. Pollack, Religion und Moderne. Versuch einer Bestimmung ihres Verhältnisses, [w:] Gottesrede in postsäkularer Kultur, red. P. Walter, Freiburg im Breisgau 2007, s. 32. 
nych dziedzin życia społecznego od roszczeń religii jako instytucji dążącej poprzez struktury kościelne do sprawowania nad nimi kontroli"24. Autonomiczne subsystemy (systemy partykularne) nie działają według norm opartych na wyższych celach czy wartościach, ale według własnych doraźnych wymagań efektywnego funkcjonowania. „Świat religii” jest także jednym z subsystemów społecznych konkurujących z ofertą innych światopoglądów. Jednostka niepodlegająca jednemu społecznie ustalonemu porządkowi świata, musi wciąż dokonywać wyborów pomiędzy pomnażającymi się alternatywami działania ${ }^{25}$.

Zasada funkcjonalnego zróżnicowania ma różne konsekwencje dla akceptacji religijnych pojęć, praktyk i tożsamości. Według jednej z hipotez w warunkach funkcjonalnej tożsamości jednostka w swoim myśleniu, odczuwaniu i działaniu podlega wpływom zróżnicowanych subsystemów społecznych, nie zależy zaś tylko od jednego subsystemu (np. religijnego), który motywowałby możliwości działania w dziedzinie życia rodzinnego, politycznego czy zawodowego. W sytuacji oddziaływania różnych subsystemów społecznych siła motywująca systemu religijnego słabnie (negatywne konsekwencje). Religia nie jest wpisana obligatoryjnie w określony porządek polityczno-prawny, społeczno-gospodarczy czy społeczno-kulturowy.

Według przeciwstawnej hipotezy dyferencjacja funkcjonalna oznacza także wzrost autonomii samego systemu religijnego, w ramach którego uzyskuje się odpowiedzi na problemy przygodności życia. Zbawienie jednostki nie zależy już od uwarunkowań zewnętrznych czy rozważenia korzyści, lecz jest związane z poczuciem bliskości w odniesieniu do podstawowych wierzeń tej wspólnoty. W tym sensie autonomia systemu

24 F.-X. Kaufmann, Czy chrześcijaństwo przetrwa?, tłum. U. Poprawska, Kraków 2004, s. 11-12.

25 A. Nossol, Troska Kościoła o budowę zjednoczonej Europy jako wspólnoty wartości i kultury, ,Zeszyty Społeczne KIK” 2007, nr 15, s. 7. 
religijnego przynosi pozytywne konsekwencje ${ }^{26}$. Kościoły stają się sektorem (subsystemem) pluralistycznego społeczeństwa. Mają one swoje wartości, reguły działania, język, symbole, strukturę władzy itp. Przyznaje się im prawo do pielęgnowania swojej hierarchii wartości i rozwijania własnych form życia religijnego, podobnie jak i innym grupom społecznym. Kościołom przysługuje prawo do działania jako jednej z wielu sił społecznych w procesie modernizacji, utraciły one swoją uprzywilejowaną, centralną pozycję kulturową w społeczeństwie. W tym kontekście stawia się tezę o zmierzchu Kościoła ludowego i tworzeniu się Kościoła mniejszości, Kościoła diaspory, Kościoła wspólnoty, Kościoła wyboru.

Procesowi modernizacji społecznej towarzyszy z jednej strony dyferencjacja (rozwarstwienie), z drugiej zaś pluralizm społeczno-kulturowy i strukturalny indywidualizm. Prowadzi to w konsekwencji do osłabienia więzi wspólnotowych i konsensu aksjologicznego. Anomia, czyli rozpad więzi solidarnościowych i wspólnotowych oraz wartości, ma określone konsekwencje dla religijności i dla Kościołów chrześcijańskich. Wynikające z modernizacji tendencje pluralistyczne i indywidualistyczne prowadzą do erozji struktur wiarygodności stworzonych w przednowoczesnych społeczeństwach przez monopolistyczne instytucje polityczne i kościelne. Sprzyjają one $-\mathrm{z}$ drugiej strony $-\mathrm{w}$ kształtowaniu się nowych form religijności i duchowości. Według niektórych socjologów rozwój nowych form religijności i duchowości jest przejawem tendencji desekularyzacyjnych we współczesnym świecie i zaprzeczeniem procesów sekularyzacyjnych. Jeszcze inni przyjmują tezę, że sekularyzacja jest niezależna od modernizacji ${ }^{27}$.

26 D. Pollack, Religion und Moderne. Versuch einer Bestimmung ihres Verhältnisses, [w:] Gottesrede in postsäkularer Kultur, red. P. Walter, Freiburg im Breisgau 2007, s. 33.

27 G. Davin, Socjologia religii, tłum. R. Babińska, Kraków 2010, s. 342. 


\section{Modernizacja społeczna jako pluralizm społeczno- -kulturowy a religia}

Socjolog amerykański Peter L. Berger, który w latach 60. i 70. ubiegłego wieku przyczynił się do utrwalenia w socjologii tezy sekularyzacyjnej, w późniejszych latach od niej wyraźnie odszedł. W wywiadzie z 2011 r. stwierdził, że skończyła się epoka, kiedy socjologowie automatycznie łączyli modernizację z sekularyzacją. Dzisiaj okazuje się, że wyjątkiem w skali globalnej nie jest Ameryka ze swoim połączeniem nowoczesności $\mathrm{z}$ religijnością, ale Europa ze swoim eurosekularyzmem. Nie jesteśmy dziś świadkami upadku religii. Według Bergera błąd zwolenników poglądu o zbieżności modernizacji i sekularyzacji poległ na tym, że nie dokonali oni rozróżnienia pomiędzy sekularyzacją i pluralizacji religii. Pluralizm religijny to o wiele ważniejsze zjawisko w skali światowej niż sekularyzacja ${ }^{28}$.

„Podstawowe procesy modernizacji - takie jak powszechne szkolnictwo, urbanizacja, rozwój środków masowego przeka$\mathrm{zu}$ - prowadzą do współwystępowania obok siebie na pokojowych warunkach różnych punktów widzenia i systemów wartości. To niezwykle ważne zjawisko, które zmienia naturę religii, ale niekoniecznie jest tożsame z jej zanikiem. Pluralizm i rozmnożenie dostępnych możliwości oraz związana z tym konieczność wyboru nie muszą prowadzić do wyboru laicyzmu. Równie dobrze człowiek nowoczesny może wybrać religię, choć warunki, w jakich tego dokonuje, zmieniają zarówno strukturę instytucjonalną poszczególnych kościołów, jak również indywidualne doświadczenie religijne. Człowiek wybiera dziś religię bardziej samodzielnie niż jeszcze kilka-

28 Religia i nowoczesność. Rozmowa z amerykańskim socjologiem religii Peterem Bergerem, „Europa. Miesięcznik Idei” 2011, nr 5, s. 24. 
dziesiąt lat temu. [...]. Żadna tradycja religijna czy kulturowa nie jest już uznawana za niepodważalny pewnik. Zamiast tego nieustannie podlega kwestionowaniu, czyli innymi słowy zostaje zrelatywizowana. To bardzo powszechne zjawisko, nie tylko w Europie"29.

Ludzie w nowoczesności są religijni, tyle że inaczej. Zmieniło się nie tyle to, w co wierzymy, ale jak wierzymy. Pluralizm społeczno-kulturowy i jego dynamika sprawiają, że coraz trudniej jest utrzymać pewność światopoglądową, nie angażując się w nieustanny proces walki ze samym sobą i ze światem zewnętrznym. We współczesnym świecie jednostki coraz częściej samodzielnie konstruują swoją własną religijność. Według Bergera „ludzie wykazują potrzebę nadania własnej egzystencji jakiegoś ostatecznego sensu - zwłaszcza w obliczu zła, cierpienia czy śmierci. Potrzeba ta zdaje się być niezbywalna - pomimo licznych prób jej usuwania nieustannie pojawia się w tej lub innej formie. Wychodząc z takiego założenia, nie jesteśmy w stanie przewidzieć konkretnego kształtu, w jakim religia będzie powracać do naszego życia, ale w jakiejś formie na pewno powróci. Całkowicie areligijne, świeckie światopoglądy mają jedną zasadniczą wadę - nie pomagają ludziom w radzeniu sobie ze zwyczajnymi życiowymi kryzysami. [...]. Potrzeba wyjaśnienia sensu cierpienia, zła i skończoności to czynnik, który napędza żywotność różnego rodzaju kultów religijnych"30.

W wyżej wspomnianym wywiadzie Peter L. Berger wyraźnie zaznaczył, że nigdy nie uznawał i nie uznaje nowoczesności oraz pluralizmu za zjawiska zagrażające religijności. Paradoksalnie znaleźliśmy się w pewnym sensie w sytuacji analogicznej do początków chrześcijaństwa. Od kiedy chrześcijaństwo stało się oficjalną religią Cesarstwa Rzymskiego, przez następne stu-

\footnotetext{
29 Ibidem.

30 Ibidem, s. 25.
} 
lecia prawdy religijne pozostawały niekwestionowane. „Obecnie z powodów, które już omówiliśmy, ten czas dobiegł końca. W pewnym sensie powróciliśmy więc do czasów apostolskich, kiedy chrześcijaństwo jako całkowicie nowa religia musiało dopiero zostać ukształtowane. W tamtej epoce przyjęcie wiary chrześcijańskiej wymagało świadomego wyboru, nie było po prostu dziedziczone. Nie uważam, by nad powrotem do takiego stanu rzeczy należało ubolewać. Chrześcijaństwo przestało być częścią kulturowego spadku przejmowanego po przodkach - wybór religii znów staje się świadomą decyzją, a instytucje religijne przekształcają się w dobrowolne stowarzyszenia. Moim zdaniem światopogląd religijny obrany wskutek własnej decyzji należy cenić wyżej niż taki, który otrzymujemy po prostu na skutek przyjścia na świat w konkretnym miejscu i kulturze"31.

Według Bergera w najbliższej przyszłości Stany Zjednoczone nie ulegną sekularyzacji, a Europa nie stanie się bardziej religijna. Nie spodziewa się on dramatycznych przekształceń, podstawowe struktury pozostaną niezmienne. Wskazuje ponadto na różne przejawy odrodzenia religijnego we współczesnym świecie, jak np. prawdziwa eksplozja ewangelikalnego protenstantyzmu, a zwłaszcza ruchu zielonoświątkowego. Jednym z głównych obszarów tej ekspansji są współczesne Chiny i Korea Południowa. Indie były zawsze krajem różnorodnym religijnie. Chiny takim krajem właśnie się stają, podobnie jak kraje Ameryki Południowej i Afryki ${ }^{32}$.

Pluralizm społeczno-kulturowy pociąga za sobą relatywizm przekonań religijnych i moralnych. Na rynku światopogladowym pojawia się wielu dostawców prawd, wartości i norm, które można przyjąć lub odrzucić. Jednostki nie czują się już związane z jednym Kościołem, który ma znaczenie wyjątkowe

\footnotetext{
31 Ibidem.

32 Ibidem, s. 26-27.
} 
i bezwzględne. Wszystkie Kościoły mogą być ważne, mieszczące się w polu wyboru jednostek, które mogą wybierać z elementów różnych kultur i religii ważne dla nich prawdy oraz tworzyć z nich własną i niespójną całość. Z punktu widzenia jednostki konstytuującej swoją tożsamość religijną podziały religijne nie mają większego znaczenia ${ }^{33}$.

Peter L. Berger podkreśla, że relatywizm religijny i moralny jest dla wielu ludzi nie do zniesienia, tęsknią oni za pewnością. Zachwyt z powodu uzyskanej wolności staje się ciężarem nie do udźwignięcia. Ci, którzy pragną pewności, są podatni na wszelkie oferty tych, którzy zapewniają, że zabezpieczą jednostce jej pragnienie bezpieczeństwa i pewności. Dotyczy to nie tylko sekt, ale i wszelkich ruchów o charakterze totalitarnym i fundamentalistycznym. Ruchy fundamentalistyczne powstają nie tylko w obszarze życia religijnego, ale także w ruchach o charakterze czysto świeckim. Recepta jest taka sama: przyjdź do nas, damy ci pewność, której poszukujesz i za którą tęsknisz. Berger ujmuje ten proces w krótkiej, być może nie do końca zadowalającej formule: „nihilista staje się fanatykiem” ${ }^{34}$.

Streszczając poglądy Petera L. Bergera na temat wpływu pluralizm na religijność Grace Davie stwierdza: „Związek ten ma charakter dialektyczny: pluralizm prowadzi do erozji struktur wiarygodności stworzonych przez monopolistyczne instytucje religijne, gdyż oferuje alternatywy dla nich. Z kolei te alternatywy rywalizują ze starszymi tradycjami, przyczyniając się do dalszego podważenia ich wiarygodności - innymi słowy, do sekularyzacji. Co więcej, pluralizm stanowi nieodłączną część modernizacji, zważywszy na coraz większą mobilność nowocze-

33 G. Guizzardi, Sekularyzacja, pluralizm, nowa etyka, [w:] Co po industrializmie? red. K. Wielecki, S. Sowiński, Warszawa 2013, s. 192.

34 P.L. Berger, An die Stelle von Gewissheiten sind Meinungen getreten. Der Taumel der Befreiung und das wachsende Unbehagen darüber, „Frankfurter Allgemeine Zeitung" 1998, nr 105, s. 14. 
snego świata (zarówno jeśli chodzi o ludzi, jak i idee). Dlatego pluralizm staje się kluczową zmienną wpływającą na rozumienie związku między modernizacją a sekularyzacją. To właśnie wynikające z nowoczesności pluralistyczne tendencje okazują się niszczące dla religii" 35 .

Według konkurencyjnej hipotezy, im bardziej rynek religijny jest spluralizowany, tym witalność religijna jest wyższa. W warunkach monopolu kościelnego ludzie wierzący nie mieli możliwości wybierania spośród alternatyw, przyjmowali dostarczane im oferty religijne. Sytuacja ta sprzyjała mniejszemu zaangażowaniu się osób duchownych. W przypadku konkurencji duchowni są zmuszeni zabiegać o nowych członków, utrzymywać dawnych i podejmować nowe działania, by osiągnięcia Kościoła czy wspólnoty religijnej były bardziej znaczące. Konkurencyjny rynek religijny wymaga wciąż nowych zabiegów i poświęceń ze strony osób duchownych, nowych przejawów ofiarności.

Model rynkowy, zwany niekiedy nowym paradygmatem, nie jest tylko zwykłą metaforą, lecz stanowi podstawową zasadę funkcjonowania religii. Im więcej organizacji religijnych jest na tym rynku, tym bardziej rozwija się konkurencja między nimi, wzrasta religijność ludzi. W modelu rynkowym religia staje się swoistym „towarem” i jest dostosowywana do potrzeb klienta, jego osobistych zainteresowań, potrzeb i uczuć. Ona sama, tj. religia, nie tyle kieruje zachowaniami jednostek, ile raczej jest sposobem poprawy samopoczucia i duchowego dobrostanu. Autorytety religijne tracą na znaczeniu, religijność pozostaje pod wpływem indywidualnej świadomości i jest związana z osobistym doświadczeniem jednostki (nie ortodoksja, lecz preferencja i opcja). Wyznawanie jakiejś wiary (religii) nie musi oznaczać pozostawanie w niej przez całe życie.

35 G. Davie, Socjologia religii, tłum. R. Babińska, Kraków 2010, s. 88. 
W warunkach pluralizmu społeczno-kulturowego pojawiają się na rynku światopoglądowym nowe oferty religijności $i$ alternatywnej duchowości. Wzrost ofert religijnych na rynku światopoglądowym nie prowadzi automatycznie do rewitalizacji sceny religijnej. Błędem teorii ekonomicznego modelu rynku religijnego - według niektórych socjologów - jest przyjęcie założenia, że rozszerzona czy nowa oferta religijna spotyka się zawsze z zapotrzebowaniem ludzi, nawet u tych, którzy w ogóle nie stawiają pytań religijnych i nie poszukują na nie odpowiedzi ${ }^{36}$.

Jeżeli nawet model rynkowy wydaje się nie w pełni pasować do Europy (w przeciwieństwie do USA), w której dominują Kościoły instytucjonalne (monopol religijny), to sytuacja się zmienia. Być może zwiększające się zróżnicowania religijne w społeczeństwach zachodnich przyniosą w przyszłości pozytywne efekty i konsekwencje. Elementy teorii rynkowej mogą już dzisiaj tłumaczyć wysoką religijność i kościelność w niektórych państwach. Luca Diotallevi wskazuje na przykładzie Włoch, że mimo swoistego monopolu Kościoła katolickiego jest on wewnętrznie bardzo zróżnicowany, co daje właśnie efekt pluralizmu w postaci relatywnie wysokiej religijności. To samo można by odnieść do Polski i Irlandii. Dzięki teorii rynkowej socjologowie religii w Europie zaczęli dostrzegać wyraźniej, że sytuacja religijna w tym rejonie świata jest także zróżnicowana i wielokształtna ${ }^{37}$.

Pluralizacja i indywidualizacja prowadzą do prywatyzacji i subiektywizacji wiary. Religia traci na znaczeniu jako trady-

36 W. Jagodzinski, Religiöse Stagnation in den neuen Bundesländern: Fehlt das Angebot oder fehlt die Nachfrage?, [w:] Religiöser und kirchlicher Wandel in Ostdeutschland 1989-1999, red. D. Pollack, G. Pickel, Opladen 2000, s. 48-69.

37 H. Knoblauch, Religion und Soziologie, [w:] Religion in der modernen Lebenswelt. Erscheinungsformen und Perspektiven, red. B. Weyel, W. Gräb, Göttingen 2006, s. 285. 
cyjny element integracji społecznej (wspólnotowej), a zyskuje poprzez wolny wybór rangę wartości osobowej. Zderzenie się odmiennych kultur religijnych przyczynia się zarówno do subiektywizacji przekonań, jak i międzynarodowych oraz międzywyznaniowych zapożyczeń. Postawie biernej akceptacji przeciwstawia się postawa czynnej asymilacji, cechująca się orientacją na wartości, a nie na instytucje. Postawę wyboru charakteryzuje subiektywizacja wiary, przesunięcie akcentu znaczeniowego ze wspólnoty na indywidualizację doświadczeń religijnych. Ten typ religijności, odchodzący od wspólnoty, a koncentrujący się na prywatności wiary, określany jest przez socjologów jako religijność prywatna, mozaikowa, rozproszona, pozakościelna czy niewidzialna.

Socjologowie zastanawiający się nad przyszłą trajektorią religii mówią o wzrastającym zróżnicowaniu religijnym oraz zsekularyzowanych i zdesekularyzowanych zjawiskach. Współczesne teoretyczne dyskusje na temat pluralizmu religijnego, $w$ tym także dotyczące podaży i popytu na rynku religijnym nie doprowadziły do jednoznacznych wniosków. Można jednak spodziewać się nieco odmiennych przemian religijnych w społeczeństwach jednorodnych lub zróżnicowanych pod względem wyznaniowym (liczebność i siła ich oddziaływania). Wpływ modernizacji społecznej na religijność będzie przebiegał inaczej w społeczeństwach, w których identyfikacje religijne splatają się z identyfikacjami narodowymi, niż w społeczeństwach, gdzie takiego związku nie ma ${ }^{38}$.

Na kontynencie azjatyckim sytuacja ekonomiczna jest bardzo zróżnicowana. Niektóre państwa są wysoko rozwinięte (np. Korea Południowa), inne są na drodze rozwoju dzięki skutecznym programom ekonomicznym, jeszcze inne znajdują

38 K. Koseła, Religijność młodych Niemców i Polaków, [w:] Młodzi Polacy i młodzi Niemcy w nowej Europie, red. K. Koseła, B. Jonda, Warszawa 2005, s. 250. 
się w stanie nędzy i należą do najuboższych krajów na ziemi. Przyszłość Korei Południowej jawi się optymistycznie, wchodzi ona w nową epokę rozwoju gospodarczego opartego na technologiach przyjaznych środowisku ${ }^{39}$. Procesy sekularyzacyjne przebiegają tu odmiennie niż w Europie. Ale i tu - jak stwierdza Jan Paweł II w adhortacji apostolskiej Ecclesia in Asia - „W procesie rozwoju materializm i sekularyzm również zyskują na sile, zwłaszcza w rejonach miejskich. Te ideologie, które podważają wartości tradycyjne, społeczne i religijne, stwarzają niebezpieczeństwo trudnego do przewidzenia niszczenia kultur Azji”(nr 7) ${ }^{40}$.

\section{Modernizacja społeczna i religia w Korei Południowej}

Korea Południowa charakteryzuje się ogromną różnorodnością religijną, przy znaczącej liczbie ludności pozostającej poza zorganizowanymi religiami. Pierwotną religią Korei był szamanizm, później (od IV w. po Chrystusie) zyskiwały na znaczeniu buddyzm, później konfucjanizm i taoizm. Od 1955 r. istnieją wspólnoty muzułmańskie (obecnie około 200 tys. osób w całej Korei). W 1976 r. został otwarty w Seulu główny meczet w kraju, inne są na prowincji. Buddyzm i konfucjanizm wywarły większy wpływ na życie Koreańczyków niż inne religie, także szamanizm odgrywa ważną rolę w ich życiu, niosąc pomoc w kontaktach ze światem duchowym i w kształtowaniu przyszłości ${ }^{41}$.

39 W. Bołkunow, Wybrane aspekty rozwoju gospodarczego oraz rola przedsiębiorczości w Korei Potudniowej, [w:] Azjatyckie życie gospodarcze na początku XXI wieku, red. J. Marszałek-Kawa, Toruń 2012, s. 360.

40 I.S. Ledwoń (red.), Kościót Azji a religie, Lublin 2018; J.M.C. Francisco, Das Christentum als asiatistische Religion, „Concilium. Internationale Zeitschrift für Theologie” 2018, nr 1, s. 19-27.

41 M. Jacoby, Korea Potudniowa. Republika żywiołów, Warszawa 2018, s. $61-92$. 
Konstytucja koreańska gwarantuje wolność religii, nie ma oficjalnej religii państwowej. Obywatele Republiki mają konstytucyjne zagwarantowaną wolność wyznania, państwo nie preferuje żadnej religii. Społeczeństwo koreańskie staje się wieloetniczne, wielokulturowe i wielowyznaniowe. Ludność Korei może swobodnie prowadzić życie religijne według własnego wyboru i przekonań czy to jako wyznawcy jednej z głównych religii, a mianowicie buddyzmu, konfucjanizmu, chrześcijaństwa, islamu, czy też jako wyznawcy koreańskich religii rodzimych, takich jak buddyzm Won czy czondoizm lub czundoizm (Niebiańska Droga) - synkretyczna religia koreańska łącząca w sobie elementy taoizmu, konfucjanizmu, buddyzmu i chrześcijaństwa.

Wraz ze wzrostem gospodarczym od lat 60 . XX w. rozpoczęła się ekspansja chrześcijaństwa. Niekiedy mówi się o „drugim szoku kulturowym”. W 2015 r. - według spisu powszechnego - 56\% ludności przyznawało się do jakieś religii, 44\% - nie było wyznawcą jakieś religii. Wśród tych, którzy są członkami organizacji religijnych, protestantyzm stanowi 45\%, buddyzm $35 \%$ i katolicyzm 18\%. Niewielki odsetek Koreańczyków (2\%) to członkowie innych religii, w tym: buddyzm Won, konfucjanizm, czondoizm, Daesun Jinrihoe, daejongism, jeungsanism, islam i chrześcijaństwo prawosławne. W skali całego kraju 19,7\% należało do rozmaitych Kościołów protestanckich i 7\% do Kościoła katolickiego. Protestantyzm jest nie tylko religią chrześcijańską w Korei, ale pełni ważną rolę w życiu politycznym, społecznym, kulturalnym i wychowawczym ${ }^{42}$.

Pierwsi misjonarze katoliccy przybyli z Chin do Korei w XVII w. W 1984 r. obchodzono 200-lecie istnienia Kościoła katolickiego w tym kraju. W 1885 r. było 23 tys. katolików

42 http:/www.korea.net/AboutKorea/Korean-Life/Religion [dostęp: 12.04.2019]; A. Wróblewska, Obraz chrześcijaństwa w Korei w świetle koreańskiego piśmiennictwa religijnego, naukowego i literackiego, Poznań 2007 (mps pracy doktorskiej). 
i 12 księży. W latach 1865-1873 zaznaczyło się wielkie prześladowanie chrześcijan. W 1909 r. Kościół katolicki w Korei liczył 69 parafii, 71 księży ( $w$ tym 15 rodzimych), 41 alumnów, 59 sióstr zakonnych i ponad 73 tys. wiernych. Po podziale państwie w Korei Południowej były w 1970 r. 3 metropolie 12 diecezji, jedno opactwo samodzielne, 389 parafii, 506 księży diecezjalnych i 622 księży zakonnych, 539 alumnów, 178 braci zakonnych i 2387 sióstr zakonnych. W 2001 r. w Korei Południowej było 3,8 mln katolików, 11 mln protestantów, 5200 prawosławnych. Kościół katolicki liczył 3 metropolie, 13 diecezji, jedno opactwo samodzielne, 1122 parafie, 2194 księży diecezjalnych i 426 księży zakonnych, 1617 alumnów, 818 braci zakonnych, 8067 sióstr zakonnych ${ }^{43}$.

Dopiero po wojnie koreańskiej (1950-1953) rozpoczął się powolny proces rozwoju katolicyzmu w tym państwie. W $1945 \mathrm{r}$. było 150 tys. katolików, w 1965 r. - 183,6 tys., w 1970 r. 763 tys., w 1975 r. 1017 tys., w 1980 r. - 1397 000, w 1982 r. - 1578 tys., w połowie 1983 r. - 1 685,5 tys. katolików. „Prawie 80\% katolików koreańskich zostało ochrzczonych w ostatnich dwudziestu latach, a ponad 50\% wszystkich członków Kościoła katolickiego, to ludzie młodzi do 20 roku życia. Zauważa się również stały procentowy przyrost katolików, np. w $1970 \mathrm{r}$. katolicy stanowili 2,4\% ogółu mieszkańców Korei, w 1975 r. 2,9\%, w 1980 r.- 3,6\%, obecnie zaś około 4\% wszystkich Koreańczyków (ponad $40 \mathrm{mln}$ ), to katolicy. Katolicyzm cieszy się niezwykłym zainteresowaniem, zwłaszcza wśród studentów i inteligencji technicznej. W samej tylko katedrze w Seulu udziela się każdego roku chrztu 300-400 studentom uniwersyteckim" ${ }^{\prime 4}$.

43 A. Kość, B. Modzelewska, R. Dziura, A. Bender, Korea, [w:] Encyklopedia katolicka, t. IX, red. B. Migut et al., Lublin 2002, kol. 843.

44 A. Wieczorek, Korea, [w:] Jan Pawet II na Dalekim Wschodzie. $2 \mathrm{~V}$ 1984-11 V 1984. Homilie i przemówienia, red. J. Sobiepan, Warszawa 1988, s. 192. 
Prawdziwe przyspieszenie rozwoju katolicyzmu w Korei Południowej nastąpiło w latach 80. XX w. To, co dzieje się w tym kraju o starej kulturze, jest czymś niezwykłym. Z roku na rok notuje się coraz większą liczbę nawróceń, a tempo wzrostu liczby katolików ponadtrzykrotnie przewyższa tempo przyrostu naturalnego, który wynosi 1,1\%. „Nawróceni wywodzą się przede wszystkim z miast. Pochodzą z różnych warstw społecznych - od deputowanych do prostych robotników. Jakie są główne powody tych nawróceń. Niechrześcijanie widzą w Kościele katolickim religię prawdziwą, która potrafi odpowiedzieć na ich aktualne potrzeby. Jest to Kościół, który głosi sprawiedliwość, nie podporządkowuje się partiom politycznym, nie idzie na kompromis z władzą, szanuje wolność osobistego wyboru. Koreańczycy potrzebowali pewności i podpory duchowej, której nie znaleźli w religiach tradycyjnych, buddyzmie, szamanizmie i szintoizmie. Do tak licznych nawróceń przyczyniają się misjonarze świeccy, zaangażowani w przeżywanie swojej wiary i niesienie autentycznego świadectwa. Nawrócenia w Korei są czymś niezwykłym w całej historii Kościoła Azji. Można je jedynie porównać $\mathrm{z}$ równie masowymi nawróceniami w XVII i XVIII w. w Japonii i na Filipinach"45.

W 1983 r. ludność Korei Południowej wynosiła 40347150 mieszkańców, w tym 1551888 katolików (3,94\%). W całym kraju było 650 parafii i 1705 stacji misyjnych, 1030 kapłanów diecezjalnych (955 - tubylcy, 75 - zagraniczni), 239 kapłanów zakonnych (91 - tubylcy, 148 - zagraniczni), 304 braci zakonnych (259 - tubylcy, 45 - zagraniczni), 3692 siostry zakonnne (3531 - tubylcy, 161 - zagraniczni) i 827 seminarzystów. Kościół katolicki w Korei Południowej w 1983 r. prowadził 215 przedszkoli z liczbą 13721 dzieci, 6 szkół I stopnia z liczbą 5933 uczniów, 31 szkół II stopnia z liczbą 32943 uczniów, 36

45 Ibidem, s. 192. 
szkół średnich z liczbą 48160 uczniów, 7 szkół zawodowych z liczbą 787 uczniów i 8 uczelni z liczbą 18221 studentów ${ }^{46}$.

Według Annuarium Statisticum Ecclesiae w 1989 r. liczba ludności Korei Południowej wynosiła 4230 tys. mieszkańców, w tym 2571 tys. katolików. Na jednego księdza przypadało 11538 mieszkańców i 1258 katolików. W całym kraju działało 777 parafii z proboszczem, 1396 parafii bez stałego proboszcza i 103 inne centra religijno-kościelne. W 2016 r. liczba ludności wzrosła do 52013 tys., a liczba katolików do 5559 tys. Strukturę administracyjną Kościoła katolickiego stanowiły 3 metropolie, 12 diecezji i 1 wikariat apostolski; 2 kardynałów, 6 arcybiskupów i 26 biskupów (razem 34); 1695 księży diecezjalnych i 29 księży zakonnych obsługujących 1724 parafie; ogółem było 827 księży diecezjalnych i 681 księży zakonnych, 8623 zakonnice i 13283 katechistów; 313 alumnów diecezjalnych i zakonnych (filozofia i teologia). W 2016 r. udzielono łącznie 109815 chrztów (21 653 to chrzty do 7. roku życia i 88162 powyżej 7. roku życia). Liczba małżeństw zawartych między katolikami wynosiła 6611, między katolikami i niekatolikami 10705 (łącznie 17 316), liczba bierzmowanych kształtowała się na poziomie 52806 osób ${ }^{47}$. Liczba katolików zwiększyła się do 5732 tys., liczba parafii - do 5732, liczba księży diecezjalnych - 1701.

Koreę Południową odwiedził dwukrotnie papież Jan Paweł II i jeden raz papież Franciszek. Podczas swojej wizyty w Korei Południowej w dniach 3-7 maja w 1984 r. Jan Paweł II mówił o wspaniałym rozkwicie wiary chrześcijańskiej w Korei Południowej, o niezwykłej żywotności parafii katolickich i licznych ruchach religijno-kościelnych, o wspaniałej pracy szkół i szpitali, o dobrej organizacji administracyjnej Kościoła. Papież błogosławił wszystkim systematycznym i wytrwałym staraniom o dobro

46 Ibidem, s. 189-191.

47 Annuarium Statisticum Ecclesiae 2016, „Libreria Editrice Vaticana, Cittá del Vaticano" 2018, s. 39, 120, 333. 
rodziny, programom ewangelizacji najbliższego środowiska, o budowaniu parafii i wspólnot, umacnianiu diecezji i wreszcie solidarności ogarniającej cały kraj. Co roku ponad 100 tys. Koreańczyków przyjmuje chrzest. W czasie w swego pobytu w tym kraju Jan Paweł II kanonizował 103 męczenników koreańskich, w tym beatyfikowanego w 1925 r. Andrewa Kima ${ }^{48}$. Wszystko to dzieje się w warunkach gwałtownie rozwijającego się gospodarczo i społecznie państwa, o wysokim wskaźniku modernizacji.

W przemówieniu pożegnalnym na lotnisku w Seul-Kimpo w dniu 7 maja 1984 r. Jan Paweł II powiedział: „, I to nasze spotkanie dało mi wielką i odnowioną nadzielę. Młodzieńcza żywotność, budujący zapał, gotowość podjęcia każdego wysiłku i ofiary, koniecznej zarówno do budowania wzorowego narodu, jak i prawdziwie chrześcijańskiej wspólnoty - wszystko to pobudza do ufności i nadziei na lepsze jutro" ${ }^{\text {"9 }}$. Druga podróż do Korei odbył Jan Paweł II z okazji 44. Międzynarodowego Kongresu Eucharystycznego w dniach od 6 do 8 października 1989 r.

Podróż papieża Franciszka do Korei Południowej w dniach 13-18 sierpnia 2014 r. odbyła się z okazji VI Azjatyckich Dni Młodzieży. Po powrocie z Korei podczas audiencji generalnej w dniu 20 sierpnia 2014 r. Franciszek podkreślił, że jest to kraj, który zaznał wielkiego i szybkiego rozwoju ekonomicznego. Jego mieszkańcy są ludźmi bardzo pracowitymi, zdyscyplinowanymi, lubiącymi porządek, zachowują siłę odziedziczoną po przodkach. Korea należy do państw rozwiniętych, ale jak i inne państwa europejskie zmaga się z poważnymi kwestiami społecznymi, podziałami politycznymi, nierównościami społecznymi i musi zatroszczyć się o odpowiednie zarządzanie środowiskiem ${ }^{50}$.

48 Jan Paweł II, Nauczanie papieskie 1984, t. VII/1, red. E. Weron, A. Jaroch, Poznań 2001, s. 559-597.

49 Ibidem, s. 597.

50 „L'Osservatore Romano” 2014, nr 8-9, s. 30. 
Katolicy stanowią w tym kraju znacząco i szybko rosnącą mniejszość. Wzrost pozycji katolików i szerzej - chrześcijaństwa budzi niepokój buddystów, religii zakorzenionej od wieków w Korei. W ostatnich kilku dekadach rozwija się zarówno buddyzm, jak i protestantyzm, katolicyzm, Kościół Zjednoczeniowy Muna. Działa kilkaset sekt religijnych wywodzących się z chrześcijaństwa, buddyzmu, szamanizmu, islamu i innych religii. Można określić sytuację religijną w Korei jako swoistą mozaikę wielkich religii, Kościołów chrześcijańskich i różnorodnych sekt i ruchów religijnych. Według statystyk państwowych z 2015 r. 44\% ludności Korei nie było wyznawcą jakiejś religii.

\section{Uwagi końcowe}

Do niedawna przyjmowano w socjologii dość powszechnie tezę, że między modernizacją społeczną a religijnością istnieje współzależność, najczęściej jednokierunkowa: im więcej modernizacji, tym mniej religijności, im społeczeństwo jest bardziej modernizowane, tym bardziej zsekularyzowane. Dzisiaj coraz częściej mówi się o wielu odmianach modernizacji i tylko niektóre z nich łączą się nieuchronnie z sekularyzacją. Część socjologów w dalszym ciągu jednak zakłada niemożność pogodzenia religijności z nowoczesnością i modernizacją społeczną (sekularyzacja jako integralna część modernizacji). Według nich sekularyzacja jest zjawiskiem towarzyszącym modernizacji społecznej, jest do pewnego stopnia ogólnym trendem cywilizacyjnym. Sekularyzację uznano za coś pozytywnego, co należy po prostu przyjąć bez zastrzeżeń, a kulturową marginalizację religii jako proces nieunikniony i nieodwracalny ${ }^{51}$.

51 A. Kasperek, Teoria sekularyzacji i jej wrogowie. Próba apologii niepopularnej teorii, [w:] Między socjologia i teologia. Pola zainteresowań $i$ badań naukowych Janusza Mariańskiego, red. J. Baniak, Poznań 2010, s. $218-220$. 
Socjologia opisywała modernizację jako zjawisko wielowymiarowe, niosące nieuchronnie ze sobą w sferze religijnej sekularyzację. Religia i modernizacja prezentowały dwa przeciwstawne bieguny: ta pierwsza była postrzegana jako relikt minionego wieku, ta druga jako przejaw postępu i rozwoju. Sekularyzacja jako rezultat konfrontacji dwóch przeciwstawnych sił stanowiła jeden z najbardziej skomplikowanych obszarów badawczych socjologii. Modernizacja (industrializacja, urbanizacja, wzrost poziomu wykształcenia i zamożności, rozwój nauki) osłabia - według Pippy Norris i Ronalda Ingleharta wpływ instytucji religijnych w państwach zamożnych i powoduje, że spada liczba uczestniczących w nabożeństwach. Religia traci subiektywnie na znaczeniu w życiu obywateli ${ }^{52}$.

Współczesna modernizacja dopuszcza wiele dróg jej realizacji. Alain Tournaine mówi o jednej nowoczesności, ale o wielu ścieżkach prowadzących do modernizacji ${ }^{53}$. Europejska modernizacja społeczna jest jedną z nich, pierwszą, ale być może w przyszłości nie najważniejszą. Nie musi być także tak - jak głoszą dotychczasowe teorie modernizacji - że wraz z modernizacją społeczną ustępują całkowicie wartości tradycyjne na rzecz tego co nowoczesne. Niektóre wartości tradycyjne zachowują swoją trwałość, mimo pewnych przekształceń i modyfikacji. Zarówno modernizacja społeczna, jak i sekularyzacja przebiegają w różnych społeczeństwach na różne sposoby, nie ma pomiędzy nimi deterministycznych zależności. Teza sekularyzacyjna nie tłumaczy wszystkich aspektów dokonujących się przemian w religijności.

Według socjologa niemieckiego Hansa Joasa nie ma jednoznacznego związku przyczynowo-skutkowego między moder-

52 P. Norris, R. Inglehart, Sacrum i profanum. Religia i polityka na świecie, red. R. Babińska, Kraków 2006, s. 55-56.

53 A. Touraine, Po kryzysie, tłum. M. Frybes, Lublin 2013, s. 83. 
nizacją społeczną a sekularyzacją. Poza Europą odnotowuje się $\mathrm{w}$ wielu państwach znaczną mobilizację religijną. Są kraje wysoko zmodernizowane, jak USA czy Korea Południowa, które równocześnie wykazują znaczną witalność i religijną ,pproduktywność". Religijny pluralizm w Stanach Zjednoczonych, a także rozdział Kościoła i państwa, przyczynił się do witalności religijnej. Akceptacja dyferencjacji funkcjonalnej przez wspólnoty religijne może wzmóc także witalność religijną w społeczeństwie. Jeżeli nawet większość społeczeństw zachodnioeuropejskich i niektóre państwa pozaeuropejskie (np. Nowa Zelandia) oraz niektóre społeczeństwa postkomunistyczne są silnie zsekularyzowane, to w świetle danych dotyczących całego świata trudno byłoby zaakceptować tezę o ścisłym związku modernizacji i sekularyzacji ${ }^{54}$. W kontekście Ameryki Północnej i Łacińskiej, Afryki, Indii, świata arabskiego i wielu innych państw (np. Korea Południowa) Europa stanowi pod względem religijnym przypadek szczególny ${ }^{55}$.

Modernizacja społeczna i związane z nią różnorodne trendy społeczne nie działają na jakiejś nieuchronnej i deterministycznej zasadzie, niezależnej od idei i działań ludzi. Nie ma takiej z góry ustalonej konieczności, według której nowoczesne społeczeństwa muszą być - niejako z natury - świeckie i niereligijne. Czy takimi się stają czy nie, zależy od decyzji ludzi, od ich świadomych wyborów, od niezamierzonych konsekwencji tych wyborów, od konkurencyjności i wpływów między rozmaitymi grupami, od rozmaitych kontekstów społeczno-kulturowych. Uwarunkowania zewnętrzne związane z dyferencjacją społeczną, dobrobytem, pluralizmem i indywidualizmem odgrywają pewną rolę współkształtującą kon-

54 H. Joas, Führt Modernisierung zur Säkularisierung?, [w:] Gottesrede in postsäkularer Kultur, red. P. Walter, Freiburg im Breisgau 2007, s. 18.

55 J. Paulas, J. Šebek (red.), Anselm Grün odpowiada na pytania, tłum. J. Zychowicz, Kraków 2003, s. 157. 
dycję religijną społeczeństw. Współczesne społeczeństwa nie są areligijne, tylko inaczej niż dawniej religijne.

W warunkach poszerzającej się ustawicznie możliwości kształtowania własnego życia jednostka jest zmuszona podejmować wciąż nowe decyzje („od losu do wyboru”, upodmiotowienie, autonomia, emancypacja, samostanowienie). W codzienności ujawniają się nie tylko zinstytucjonalizowane formy religijności, ale i różnorodne formy nowej religijności i duchowości, które mogą charakteryzować zarówno członków, jak i nie-członków organizacji religijno-kościelnych. Można przyjąć założenie, że $\mathrm{w}$ warunkach modernizacji społecznej religijność nie upada, lecz podlega dynamicznym przemianom, zarówno w kierunku podtrzymywania konsensu religijnego, jak i dissensu. Z trzech konkurencyjnych hipotez: a) o utracie funkcji religii (przesuwanie się religii z życia społecznego do prywatnego); b) o zmierzchu, a nawet upadku religii (agnostycyzm, indyferentyzm, ateizm); c) o dynamice i transformacji form religijności, wydaje się, że najbardziej empirycznie uprawomocniona jest hipoteza trzecia.

Jeżeli nawet modernizacja społeczna nie zawsze prowadzi do wyraźnych i postępujących procesów sekularyzacyjnych, to jej obecność we współczesnym świecie nie może podlegać zakwestionowaniu. Także teorie sekularyzacyjne w swoich zmodyfikowanych kształtach są $\mathrm{w}$ dalszym ciągu przydatne $\mathrm{w}$ wyjaśnianiu zmian $\mathrm{w}$ religijności, ale nie na zasadzie jedynego paradygmatu. Wielokierunkowe zmiany w religijności współczesnej wymagają wielu modeli wyjaśniających. Socjologia religii jest nauką wieloparadygmatyczną, a teoria sekularyzacji może być także przydatna w interpretacjach transformacji religijnych we współczesnym świecie. Trzeba jednak wyraźnie podkreślić, że różne postaci modernizacji społecznej korespondują z różnymi formami zmian w religijności.

Teorię sekularyzacji należy udoskonalać, ale nie należy jej odrzucać, przede wszystkim weryfikować w różnych kontek- 
stach społeczno-kulturowych. Przypadek Korei Południowej pokazuje, że religia istnieje jako część integralna nowoczesnych czy modernizujących się społeczeństw. Do sytuacji w tym kraju nie pasują teorie socjologiczne sekularyzacji, które powstały w kontekście europejskim, co najmniej wymagaja one znacznej modyfikacji. W ostatnich latach sytuacja religijna w Korei Południowej ulega szybkim zmianom. Zmiany w religijności współczesnej w tym kraju wskazują na bardziej złożone kształty i mechanizmy jej przekształceń w społeczeństwie, niż wyznaczały to teorie sekularystyczne. W wielu państwach pozaeuropejskich tradycyjne formy religijności są w dalszym ciągu upowszechnione, mimo rozwoju procesów modernizacyjnych. To wszystko daje podstawy do zwątpienia w prawomocność tezy o niepołączalności modernizacji i religijności oraz postawienia pytania czy europejska sekularyzacja związana z modernizacją społeczną jest tylko wyjątkiem a nie modelem, według którego przebiegają procesy przemian religijności.

\section{Bibliografia}

Annuarium Statisticum Ecclesiae 2016, Libreria Editrice Vaticana, Cittá del Vaticano 2018.

Baniak J., Religia katolicka i Kościót rzymskokatolicki w opiniach polskiej młodzieży. Od akceptacji do kontestacji, Kraków 2015.

Berger P.L., An die Stelle von Gewissheiten sind Meinungen getreten. Der Taumel der Befreiung und das wachsende Unbehagen darüber, „Frankfurter Allgemeine Zeitung” 1998, nr 105, s. 14.

Bołkunow W., Wybrane aspekty rozwoju gospodarczego oraz rola przedsiębiorczości w Korei Potudniowej, [w:] Azjatyckie życie gospodarcze na poczatku XXI wieku, red. J. Marszałek-Kawa, Toruń 201. 
Davi G., Socjologia religii, tłum. R. Babińska, Kraków 2010.

Francisco J.M.C., Das Christentum als asiatistische Religion, "Concilium. Internationale Zeitschrift für Theologie” 2018, nr 1.

Gebhardt W., Believing without Belonging? Religiöse Individualisierung und neue Formen religiöser Vergemeinschaftung, [w:] Gottesrede in postsäkularer Kultur, red. P. Walter, Freiburg im Breisgau 2007.

Giddens A. (współpraca P.W. Sutton), Socjologia, tłum. O. Siara, A. Szulżycka, P. Tomanek, Warszawa 2012.

Guizzardi G., Sekularyzacja, pluralizm, nowa etyka [w:] Co po industrializmie?, red. K. Wielecki, S. Sowiński, Warszawa 2013.

Hasse E.S., Christliche Säkularität. Was glauben die Hamburger?, „Materialdienst. Zeitschrift für Religions- und Weltanschauungfragen“ 2013, nr 7.

Jagodzinski W., Religiöse Stagnation in den neuen Bundesländern: Fehlt das Angebot oder fehlt die Nachfrage?, [w:] Religiöser und kirchlicher Wandel in Ostdeutschland 1989-1999, red. D. Pollack, G. Pickel, , Opladen 2000.

Jan Paweł II, Nauczanie papieskie 1984, t. VII/1, red. E. Weron, A. Jaroch, Poznań 2001.

Jasińska-Kania A., Zmiany wartości Polaków a procesy transformacji, europeizacji i globalizacji, [w:] Wartości i zmiany. Przemiany postaw Polaków w jednoczacej się Europie, red. A. Jasińska-Kania, Warszawa 201.

Joas H., Führt Modernisierung zur Säkularisierung?, [w:] Gottesrede in postsäkularer Kultur, red. P. Walter, Freiburg im Breisgau 2007.

Kasperek Andrzej, Teoria sekularyzacji i jej wrogowie. Próba apologii niepopularnej teorii, [w:] Między socjologia $i$ teologia. Pola zainteresowań i badań naukowych Janusza Mariańskiego, red. J. Baniak, Poznań 2010. 
Kaufmann F.-X., Czy chrześcijaństwo przetrwa?, tłum. U. Poprawska, Kraków 2004.

Knoblauch H., Religion und Soziologie, [w:] Religion in der modernen Lebenswelt. Erscheinungsformen und Perspektiven, red. B. Weyel, W. Gräb, Göttingen 2006.

Koseła K., Religijność młodych Niemców i Polaków, [w:] Młodzi Polacy $i$ młodzi Niemcy w nowej Europie, red. K. Koseła, B. Jonda, Warszawa 20054.

Kość A., Modzelewska B., Dziura R., Bender A., Korea, [w:] Encyklopedia katolicka, t. IX, red. B. Migut et al., Lublin 2002. Ledwoń I.S. (red.), Kościót Azji a religie, Lublin 2018.

Marcin J., Korea Południowa. Republika żywiołów, Warszawa 2018.

Müller O., Pomiędzy sekularyzacją a rewitalizacją. Przynależność do Kościoła i religijność w Europie Środkowej $i$ Wschodniej. Analiza porównawcza rozwoju od 1989/1990 roku, [w:] Pomiędzy sekularyzacją i religijnym ożywieniem. Podobieństwa $i$ różnice $w$ przemianach religijnych $w$ Polsce $i$ w Niemczech, red. E. Firlit, M. Hainz, M. Libiszowska-Żółtkowska, G. Pickel, D. Pollack, Kraków 2012.

Norris P., Inglehat R., Sacrum i profanum. Religia i polityka na świecie, red. R. Babińska, Kraków 2006.

Nossol A.S, Troska Kościoła o budowe zjednoczonej Europy jako wspólnoty wartości i kultury, „Zeszyty Społeczne KIK” 2007, nr 15.

Paulas J., Šebek J. (red.), Anselm Grün odpowiada na pytania, tłum. J. Zychowicz, Kraków 2003.

Pickel G., Religionsmonitor verstehen was verbindet. Religiosität im internationalen Vergleich, red. B. Stiftung, Gütersloh 2013.

Pollack D., Religion und Moderne. Versuch einer Bestimmung ihres Verhältnisses, [w:] Gottesrede in postsäkularer Kultur, red. P. Walter, Freiburg im Breisgau 2007. 
Religia i nowoczesność. Rozmowa z amerykańskim socjologiem religii Peterem Bergerem,. „Europa. Miesięcznik Idei” 2011, nr 5.

Słaboń A., Modernizacja, [w:] M. Pacholski, A. Słaboń, Stownik pojęć socjologicznych, Kraków 201.

Smelser N.J., Przyczynek do teorii modernizacja, [w:] Elementy teorii socjologicznych. Materiaty do dziejów wspótczesnej socjologii zachodniej, red. W. Derczyński, A. Jasińska-Kania, J. Szacki, Warszawa 197.

Sztompka Piotr, Socjologia zmian społecznych, tłum. J. Konieczny, Kraków 2005.

Sztompka P., Socjologia. Analiza społeczeństwa, Kraków 2012. Taylor Ch., Świecka epoka. Dlaczego porzucamy religi, „Dziennik" 2007, nr 287.

Touraine A., Po kryzysie, tłum. M. Frybes, Lublin 2013.

Wieczorek A., Korea, [w:] Jan Pawet II na Dalekim Wschodzie. 2 V 1984-11 V 1984. Homilie i przemówienia, red. J. Sobiepan, Warszawa 1988.

Wohlrab-Sahr M., Religion, [w:] Lexikon Soziologie und Sozialtheorie. Hundert Grundbegriffe, red. S. Farzin, S. Jordan, P. Reclam jun., Stuttgart 2008.

Wróblewska A., Obraz chrześcijaństwa w Korei w świetle koreańskiego piśmiennictwa religijnego, naukowego i literackiego, Poznań 2007 (mps pracy doktorskiej).

\section{Abstrakt}

Od samego początku swego istnienia socjologia wiązała pozycję i rolę religii w społeczeństwie z procesami modernizacji. Wielu socjologów było przekonanych, że w wyniku procesów modernizacyjnych następują zmiany sekularyzacyjne prowadzące do osłabienia, a nawet zanikania religii w życiu społecznym. Dzisiaj nie przyjmuje się już bezdyskusyjnie, że modernizacja nieuchronnie towarzyszy zeświecczeniu (sekularyzacji) 
społeczeństw. W artykule analizujemy wpływ modernizacji społecznej (dobrobyt materialny, zróżnicowanie społeczne, pluralizm społeczno-kulturowy) na religię i religijność. Do sytuacji w Korei Południowej nie pasują zachodnie teorie sekularyzacji, co najmniej wymagają one znacznej modyfikacji. W ostatnich latach sytuacja religijna w Korei Południowej ulega szybkim zmianom w kierunku pluralizmu religijnego i religijnej „produktywności”.

Słowa kluczowe: modernizacja społeczna, sekularyzacja, religia, dobrobyt, zróżnicowanie społeczne, pluralizacji społeczno-kulturowa, Korea Południowa

\begin{abstract}
From the very beginning of its existence, sociology has linked the place and role of religion in society to modernization processes. Many sociologists were convinced that modernization would intensify secularization processes leading to the weakening or even disappearance of religion in social life. Today, the viewpoint that modernization inevitably entails secularization of societies is no longer so uncritically accepted. In the article we analyze the impact of social modernization, i.e., material prosperity, social diversity, and socio-cultural pluralism, on religion and religiosity. Western theories of secularization do not seem to fit the situation in South Korea, or at least they require significant modification. In recent years, the religious situation in South Korea has been rapidly changing towards religious pluralism and religious "productivity".
\end{abstract}

Keywords: social modernization, secularization, religion, prosperity, social diversity, socio-cultural pluralization, South Korea 


\section{Kazimierz Pierzchała}

Katolicki Uniwersytet Lubelski Jana Pawła II

https://orcid.org/0000-0001-9972-943X

\section{Edukacja wielokulturowości \\ i międzykulturowości na płaszczyźnie wzajemnych wpływów Azji i reszty świata}

„Dzieje powszechne przesuwają się
ze Wschodu na Zachód;
Europa jest niewątpliwie ich końcem,
Azja ich początkiem”
Hegel $^{1}$

Wstęp

Rozważania o kwestiach określonych w tytule przedmiotowego tekstu zapoczątkuję przywołując stwierdzenie - wielokulturowość jest zjawiskiem odwiecznym. Dzieje ludzkości wypełnione są przykładami mnogości języków, kultury - społeczności żyjących w bliskich nam i odległych regionach świata. Ukazanie w kontekście azjatyckim realizowanych przez te podmioty koncepcji edukacji wzbogaca współczesny dyskurs o nowe motywy. Pozwala śledzić związki edukacji z bieżącą sytuacją społeczno-polityczną i socjalno-bytową określonych środowisk oraz wskazać możliwości współpracy edukacyjnej i naukowej. Odrębność społeczna w wyglądzie, zwyczajach, wierzeniach, językach - i w wielu innych zagadnieniach - zas. 11.

Za: J. Kuczyński, Młodość Europy i wieczność Polski, Warszawa 1999, 
zwyczaj budziły ciekawość, innym razem lęk, ale wraz z rozwojem cywilizacji, globalizacji i coraz częstszymi kontaktami $\mathrm{z}$,innymi”, przestaje dziwić i staje się zjawiskiem naturalnym. Wcześniejszy - pewnego rodzaju - szok „odkrywania” ludzi o odmiennym kolorze skóry, przejawiający się początkowo w niezrozumiałym zachowaniu, stopniowo przemija. Jeśli intencje, przejawiane zamiary, spotykających się ludzi nie są wrogie, „inność” staje się czymś naturalnym i nie powoduje konfliktów. Co więcej - z biegiem wieków ludzie potrafili się przekonać, że zjawisko nazywane dzisiaj wielokulturowością stało się społecznym bogactwem² ${ }^{2}$.

Edukacja międzykulturowa - koncepcja pedagogiczna, której celem jest poszerzanie własnej tożsamości jednostkowej i społecznej przez kontakt z innymi kulturami, kształtowanie rozumienia odmienności kulturowych, wyzbywanie się uprzedzeń i stereotypów (np. etnicznych bądź religijnych) oraz propagowanie postaw tolerancji i dialogu; sformułowana w latach 90. XX w. w państwach zróżnicowanych etnicznie bądź o wysokim stopniu społecznego nasycenia cudzoziemcami, stanowi ważny element, m.in. edukacji historycznej, społecznej, religijnej i językowej ${ }^{3}$.

„Koncepcja edukacji - to wg Przemysława Pawła Grzybowskiego - [...] z założenia oparty na refleksji pedagogicznej projekt oddziaływań edukacyjnych adresowanych do środowiska w skali mikrospołecznej (jednostki, rodziny) oraz makrospołecznej (grupy kulturowe, społeczności regionalne, narody, środowiska międzynarodowe), realizowanych zarówno przez podmioty formalne (instytucjonalne), jak i indywidualne lub zbiorowe podmioty nieformalne. Podstawę tych oddziaływań

2 Por. T. Lewowicki, Wielokulturowość i globalizacja a strategie edukacji międzykulturowej, „Pogranicze. Studia Społeczne” 2015, t. XXV, s. 13-24.

3 Edukacja międzykulturowa, Encyklopedia PWN, https://encyklopedia. pwn.pl/haslo/edukacja-miedzykulturowa;3896549.html [dostęp: 7.04.2019]. 
stanowi zespół celów dotyczących danego środowiska edukacyjnego, wynikających z:

- potrzeb, oczekiwań i możliwości funkcjonujących w nim osób;

- dominującej w nim ideologii społecznej i wywiedzionej zeń polityki oświatowej;

- jego immanentnych czynników geograficznych, historycznych, ekonomicznych, społeczno-politycznych itp." .

Niestety w ostatnich latach część społeczeństw (w tym polskie) często spotyka się z problemami zróżnicowania kulturowego, takimi jak napięcia i konflikty, wskutek niezrozumienia różnic, dążenia do ich wyrażania, celem podkreślenia własnej tożsamości oraz utrzymywanie się negatywnych postaw, stereotypów w stosunku do Innych/Obcych. Do tego założenia prowadzi ujawniający się w wielu środowiskach brak przyzwolenia na odmienność ${ }^{5}$. Według Andrzeja Sadowskiego:

„[...] upowszechniane koncepcje wieloetnicznego, wielokulturowego społeczeństwa nie uzyskują wystarczającej akceptacji społecznej. Przeciwnie, nierzadko szczególnie na pograniczach spotykamy postawy narodowego fundamentalizmu zakładającego, że przynależność narodowa stanowi naczelne kryterium zarówno łączności, jak i podziałów społecznych"6.

Rozpatrując Azję jako pogranicze kulturowe, koncepcje edukacji azjatyckiej można sytuować w modelach edukacji wielokulturowej lub międzykulturowej, różniących się w podstawach aksjologicznych i ideologicznych oraz w zakładanych celach, treściach i formach oddziaływania edukacyjnego. Kon-

4 P.G. Grzybowski, Edukacja europejska - od wielokulturowości do międzykulturowości, Kraków 2009, s. 15.

5 Ibidem, s. 10-11.

6 A. Sadowski, Charakter międzyetnicznego wspótżycia na polsko-biatoruskim pograniczu, [w:] Edukacja międzykulturowa. W kregu potrzeb, oczekiwań i stereotypów, red. J. Nikitorowicz, Białystok 1995, s. 45. 
cepcje edukacji wielokulturowej charakteryzuje bowiem podejście asymilacyjne do Innych/Obcych oraz ujmowanie rzeczywistości społecznej w perspektywie grup i społeczeństw. Natomiast koncepcje edukacji międzykulturowej cechuje podejście integracyjne oraz ujmowanie rzeczywistości społecznej w odniesieniu do jednostek. Sytuowanie koncepcji edukacji azjatyckiej (podobnie jak i europejskiej) w modelach wielokulturowym i międzykulturowym umożliwia ukazanie ich w różnych okresach i kontekstach społeczno-kulturowych ${ }^{7}$.

W fazie gromadzenia i wstępnej analizy źródeł pod kątem występowania treści określonych tematem badań (analizy) zastosowałem bibliograficzną metodę analizy piśmiennictwa, która - zdaniem Jean-Marie Van der Marena - prowadzi do osiągnięcia następujących celów:

- teoretycznego, poprzez stworzenie syntezy tego, co się wie, jak również o czym wiadomo mniej na dany temat, zanim postawią się pytania, na które odpowiedź jest osiągalna przy obecnym stanie wiedzy;

- metodologicznego, poprzez stworzenie bilansu skutecznych (pozwalających uzyskać wiarygodne dane) narzędzi, możliwych do wykorzystania przy poszukiwaniu odpowiedzi na stawiane pytania ${ }^{8}$.

\section{Zróżnicowanie kulturowe i relacje społeczne}

Edukacyjnym wyzwaniem współczesności jest zróżnicowanie kulturowe społeczeństw. Analizując charakter stosunków społecznych istniejących w danym środowisku można wyróżnić się dwa modele zróżnicowania kulturowego:

7 P.G. Grzybowski, Edukacja europejska..., op.cit., s. 16.

8 Zob. J.-M. Van der Maren, La recherche appliquée en pédagogie. Des modèles pour l'enseignement, Paris-Bruxelles 1999, s. 178. 
Wielokulturowość to różnego rodzaju kultury i grupy narodowe, etniczne, religijne itp., żyjące na tym samym terytorium, rzadko wchodzące ze sobą w relacje. Jeśli już zachodzą pomiędzy nimi kontakty, to najczęściej przypadkowe. Odmienność społeczna postrzegana jest negatywnie, wręcz jako zagrożenie, stanowiąc element usprawiedliwiania dyskryminacji. Mniejszości mogą być biernie tolerowane, lecz nigdy akceptowane czy doceniane. Prawo przewidujące kres praktykom dyskryminacyjnym, obiektywnie nie jest przestrzegane. Mieszkańcy w takim środowisku, należący do odmiennych grup kulturowych czy etnicznych, żyjący na tym samym terytorium, lecz niejako obok siebie, ograniczają się do wymuszonych kontaktów zewnętrznych takich, które nie wymagają właściwego zaangażowania emocjonalnego. W takim wypadku społeczeństwo jest zbiorowością odrębnych grup, gdzie każda ma swoje interesy. Wyraźnie zauważalne są tendencje izolacyjne, konflikty i napięcia na styku większości i mniejszości, przy czym większość kieruje się dążeniem podporządkowania mniejszości. Stosunki społeczne pokazywane są przez pryzmat grup i ich statusów, a prawa jednostki stanowią sprawę drugorzędną. Skrajnym przykładem tego rodzaju środowiska jest Irlandia Północna czy pogranicze izraelsko-palestyńskie, pogranicze Rosji i Ukrainy, Pakistan i Indie, Chiny i Tybet itp. ${ }^{9}$

Międzykulturowość to różnego rodzaju kultury i grupy narodowe, etniczne, religijne itp., żyjące na tym samym obszarze i wchodzą ze sobą w regularne i trwałe interakcje, przy wzajemnym poszanowaniu, wymianie i zrozumieniu poszczególnych stylów życia, uznawaniu wartości i norm, co pozwala budować harmonijną formację ponad różnicami. Zróżnicowanie uznawane jest jako czynnik aktywizujący rozwój

9 P.G. Grzybowski, Edukacja w warunkach zróżnicowania kulturowego, „Przegląd Pedagogiczny” 2007, nr 1, s. 57-68. 
społeczny, polityczny i gospodarczy. W takiej relacji zachodzi proces tolerancji oraz dążenie do nawiązania i utrzymania uczciwych stosunków. Ze względu na taką czy inną tożsamość kulturową nie ma osób uprzywilejowanych i poniżonych, lepszych i gorszych. Mieszkańcy takiego środowiska, przynależący do odmiennych grup kulturowych potrafią wzajemnie współżyć i współpracować, starając się rozwiązywać napięcia oraz konflikty na drodze negocjacji i osiągania kompromisu. W przypadku występowania grup mniejszości i większości, w kontekście równowagi społecznej - nadrzędnym celem jest ich wzajemna integracja. Stosunki społeczne rozpatruje się tu nie tyle z perspektywy grupy, co jednostki, której przyznaje się prawo do posiadania i wyrażania własnej tożsamości, odmienności oraz odrębności, przy założeniu, że nie narusza Ona praw innych osób. Przykładem międzykulturowości bywają rodziny, zamieszkujące małe ojczyzny, wspólnoty lokalne i regionalne, społeczności etniczne itp., a krajami są: Australia, Kanada, USA ${ }^{10}$.

\section{Zarys relacji Azji i reszty świata}

Najprawdopodobniej ok. 3000 r. p.n.e. emigranci z Azji Mniejszej założyli pierwsze trwałe ognisko cywilizacji na Krecie, będącej wówczas odległą prowincją azjatyckiego świata. Od tej pory aż do XVI w. można będzie mówić o nieustannej rywalizacji ludów na linii Azja-Europa. Bieguny i charakter tej rywalizacji zmieniło dopiero odkrycie Ameryki oraz jego następstwa $^{11}$. Europę jako odrębną jednostkę polityczno-kulturową świadomie kontrastującą z Azją zaczęto postrzegać w okresie między wojnami grecko-perskimi, a epoką Aleksandra Wiel-

\footnotetext{
10 Ibidem.

11 H. Chołaj, Kolumb, Europa i świat, Warszawa 1995, s. 19 i n.
} 
kiego. Przyczyniło się do tego dostrzeżenie przez Greków głębokiej sprzeczności pomiędzy azjatyckim despotyzmem, a ich własną koncepcją wolności, czy ogólnie pojmowanymi wartościami helleńskimi ${ }^{12}$. Poczucie przynależności do świata europejskiego wytworzyło się wówczas na zasadzie przeciwstawienia własnych idei i wartości obcym wpływom cywilizacyjnym (w tym przypadku zwłaszcza azjatyckim), co doprowadziło do ugruntowania pojęć geograficzno-politycznych, które taką kategoryzację uzasadniały ${ }^{13}$. To właśnie ta kategoryzacja pozwoliła po raz pierwszy w środowisku europejskim rozróżniać Swoich (Europejczyków) od Obcych ${ }^{14}$.

Przedstawiono koncepcje ideologiczne określane mianem „wartości azjatyckich”, które pojawiły się w środowiskach politycznych i naukowych Azji Wschodniej. Scharakteryzowano przemówienie dotyczące „wartości azjatyckich” wygłoszone przez przywódcę Malezji Mahatira bin Mohamada, podczas XXIX Międzynarodowego Zebrania Rady Gospodarczej Basenu Pacyfiku 21 maja 1996 r. w Waszyngtonie. W swoim wystąpieniu przypomniał badania D. Hitchcocka, wymienił najbardziej cenione wartości społeczne w Azji Wschodniej oraz postulował o traktowanie ich z szacunkiem i akceptacją przez Zachód ${ }^{15}$.

12 P.G. Grzybowski, Edukacja europejska..., op.cit., s. 127.

13 K. Baczkowski, Idea jedności europejskiej w średniowieczu, [w:] $Z$ dziejów prób integracji europejskiej. Od średniowiecza do wspótczesności, red. M. Pułaski (red.), „Zeszyty Naukowe Uniwersytetu Jagiellońskiego” 1995, nr MCLXXVII, s. 11-12; N. Davies, Europa - rozprawa historyka $z$ historia, tłum. E. Muskat-Tabakowska, Kraków 1998, s. 31-41.

14 Por. J. Marszałek-Kawa, Ewa Kaja (red.), W poszukiwaniu azjatyckiej tożsamości. Dylematy i wyzwania, Torun 2014.

15 B. Drelich-Skulska, „Wartości azjatyckie” jako próba stworzenia podstaw tożsamości narodów Azji Wschodniej, „Prace Naukowe Akademii Ekonomicznej we Wrocławiu" 2007, nr 1173: Integracja a globalizacja, s. 96-103. 


\section{Edukacja w warunkach zróżnicowania kulturowego}

W literaturze przedmiotu istnieje wiele definicji edukacji. Wydaje się, że najbardziej trafną jest Zbigniewa Kwiecińskiego, który to edukację określa jako

„[...] ogół wpływów na jednostki i grupy ludzkie, wpływów sprzyjających takiemu ich rozwojowi i wykorzystywaniu posiadanych możliwości, aby w maksymalnym stopniu stały się świadomymi i twórczymi członkami wspólnoty społecznej, narodowej, kulturowej i globalnej oraz by stały się zdolne do aktywnej samorealizacji, niepowtarzalnej i trwałej tożsamości i odrębności, były zdolne do rozwijania własnego JA poprzez podejmowanie »zadań ponadosobistych «, poprzez utrzymywanie ciągłości własnego JA w toku spełniania »zadań dalekich «. Edukacja to ogół czynności prowadzenia drugiego człowieka i jego własnej aktywności w osiąganiu pełnych i swoistych dlań możliwości, jak też ogół wpływów i funkcji ustanawiających i regulujących osobowość człowieka i jego zachowanie, w relacji do innych ludzi i wobec świata" ${ }^{16}$.

Pojęcie „edukacja” w szerokim znaczeniu obejmuje:

„[...] wszelkie zorganizowane czynności nauczania, uczenia się i wychowania na wszystkich szczeblach: od państwa do organicznych instytucji prowadzących te działania zarówno bezpośrednio (np. rodzina, sąsiedztwo, rówieśnicy, przedszkole, szkoła, uniwersytet, poradnia, społeczność lokalna, samorząd, stowarzyszenia, kluby i organizacje, parafia), jak i pośrednio (np. rząd, parlament, ministerstwo, instytucje zarządzania, oceniania i kontroli, czy też treści i formy medialnego masowego przekazu informacji i kultury w telewizji, radiu, Internecie, prasie, książkach, rozrywkowych i rekreacyjnych imprezach masowych, modzie)"17.

16 Z. Kwieciński, Socjopatologia edukacji, Olecko-Białystok 1995, s. 14.

17 Idem, Przedmowa, [w:] Pedagogika - podręcznik akademicki, t. 1, red. Z. Kwieciński, B. Śliwerski, Warszawa 2003, s. 12. 
Problemy edukacji w wielorakich środowiskach można rozumować w odniesieniu do sfery grupowej i/lub międzygrupowej (optyka wielokulturowa) oraz osobowej i/lub międzyosobowej (optyka międzykulturowa). Podobnie można mówić o podmiotowości grupy (optyka wielokulturowa) oraz podmiotowości jednostki (optyka międzykulturowa). ${ }^{18}$

Oddziaływania edukacyjne dotyczą nie poszczególnych jednostek, lecz członków grup społecznych (o różnym zasięgu). Otwarcie na efekt pogranicza wymaga zarówno od podmiotów, jak osób edukowanych postawienia się w sytuacji pogranicznej. W kontekście edukacyjnym „pogranicze” oznacza miejsce, gdzie obok siebie funkcjonują różne tradycje myślowe. Uczestników zachodzących tam procesów powinno motywować to do wysiłku, zachęcać do opuszczania najczęściej sztywnych i zamkniętych ośrodków, do uwalniania się od ograniczeń. Takie podejście do edukacji i aktywności społecznej jest szczególnie trudne w środowiskach nieprzyzwyczajonych do wielości przyjętych sposobów widzenia, w państwach latami funkcjonujących w ramach ładu monocentrycznego, np. Chiny, Korea Płn., Rosja. Pogranicze, tworząc i wyzwalając tolerancję, ściśle związaną z wolnością i odpowiedzialnością, stanowi szerokie pole do nawiązywania dialogu i partnerstwa. Dostrzeżenie wartości pogranicza w kontekście edukacyjnym staje się więc wyzwaniem zarówno pedagogiki, jak i szeroko pojętej polityki oświatowej państw oraz organizacji międzynarodowych ${ }^{19}$.

„Im większe bowiem i bardziej widoczne jest zróżnicowanie w sferze publicznej kultur etnicznych, lokalnych, regionalnych, narodowych itp., tym bardziej konieczne ustawiczne rozpoznawanie stopnia zaawansowania zróżnicowania kul-

18 P.G. Grzybowski, Edukacja europejska..., op.cit., s. 65.

19 J. Nikitorowicz, Pogranicze, tożsamość, edukacja międzykulturowa, Białystok 1995, s. 11 oraz 41-42. 
turowego oraz prowadzenia pod tym względem świadomej polityki”20.

\section{Podsumowując słowami Jerzego Nikitorowicza:}

„Pluralizacja systemów wartości, postaw oraz zachowań kulturowych prowadzi do zwiększenia zakresu akceptowanej ich różnorodności, jednocześnie rodząc napięcie egzystencjalne wzbudzone koniecznością dokonywania wyborów, świadomością nieoczywistości, czy nawet wywołanej tym stanem dekompozycji istniejących form życia społecznego. Wielość konwencji i nieokreśloność kodów komunikacyjnych wymagających ustawicznego negocjowania swoich znaczeń, wywołuje potrzebę nabywania/przekazywania nowego typu kompetencji komunikacyjnych, stanowiąc wyzwanie dla twórców systemów edukacyjnych, szkoleniowych czy doradczych"21.

Edukacja wielokulturowa to model rozwiązań oparty na dążeniu do objęcia kontrolą przez państwo dynamiki kulturowej społeczeństwa i dostosowania systemu oświaty do potrzeb różnych grup kulturowych. Podstawę takiej polityki oświatowej i praktyki edukacyjnej stanowi założenie nienaruszalności obowiązujących zasad organizacji istniejącego ładu społecznego oraz utopijna wizja tegoż ładu bez konfliktów między różnymi grupami kulturowymi ${ }^{22}$. W wielu przypadkach koncepcje edukacji wielokulturowej sięgają ideologii wychowania narodowego (pedagogiki narodowej), którego naczelną zasadę

20 P.G. Grzybowski, Edukacja europejska..., op.cit., s. 66.

21 J. Nikitorowicz, Wartości etnosu jako podstawa ksztattowania tożsamości wielokulturowej, podłoże konfliktów kulturowych i cel edukacji międzykulturowej, [w:] Świat wartości i edukacja międzykulturowa, red. T. Lewowicki, E. Ogrodzka-Mazur, A. Gajdzica, Cieszyn-Warszawa 2003, s. 16.

22 Zob. W. Frankiewicz, K. Kossak-Główczewski, Edukacja regionalna $i$ alternatywna. Założenia i program pierwszego Podyplomowego Studium Edukacji Regionalnej i Alternatywnej w Uniwersytecie Gdańskim, [w:] Spoteczności pogranicza, wielokulturowość, edukacja, red. T. Lewowicki, B. Grabowska, Cieszyn-Warszawa 1996, s. 195; K. Kossak-Główczewski, Edukacja regionalna, wielokulturowa $i$ międzykulturowa a pytanie o „prywatne ojczyzny" - zarys problemu, [w:] Rodzina wobec wyzwań edukacji międzykulturowej, red. J. Nikitorowicz, Białystok 1997, s. 56. 
stanowi dobro narodu, będące najwyższym prawem. Przemysław Paweł Grzybowski jest zdania, że:

„Odwołując się do ideologii narodowej, usprawiedliwia się wtedy dyskryminację i ograniczanie praw mniejszości, które można poświęcić dla dobra ogółu. Ten sposób myślenia bywa charakterystyczny zwłaszcza dla narodów walczących o niepodległość i samodzielność, tych, które dopiero je odzyskały lub odczuwają zagrożenie własnej tożsamości. W takich warunkach u podłoża propagowanej przez nie polityki oświatowej spoczywa ideologia integrystyczna przepojona nacjonalizmem i ksenofobią"23.

Edukacja wielokulturowa odwołuje się najczęściej do modernistycznej kategorii różnorodności, zorientowanej na tworzenie społecznego konsensusu i nastawionej na ochronę interesów grupy dominującej (grup, sfer wpływów i interesów), a więc dążącej do zawłaszczania i kolonizacji mniejszości. Współcześnie, po okresie doświadczeń w wielu państwach, założenia i skutki realizacji edukacji wielokulturowej stanowią przedmiot konstruktywnej krytyki ${ }^{24}$. Atrakcyjność edukacji wielokulturowej - wg Przemysława Pawła Grzybowskiego:

„[...] o której świadczy wykorzystywanie jej założeń mimo obiektywnego stwierdzenia jej fiaska, polega dziś na jej skuteczności w utrzymywaniu statycznego stanu środowisk wielokulturowych. Dzieje się tak mimo deklarowania woli sprawowania opieki nad mniejszościami kulturowymi. Poza tym polityka asymilacji mniejszości pozwala wytłumiać przynajmniej czasowo - napięcia oraz konflikty, zapobiegając napływowi do danego środowiska Innych/Obcych, którzy bali się o swoją tożsamość i dlatego woleli trzymać się z dala od miejsc, gdzie musieliby bezwarunkowo poddawać się dominacji i w rezultacie z czasem ulec asymilacji. Mimo, że o atrakcyjności tego rodzaju polityki w wielu sferach nie mówi się z uwagi na poprawność polityczną, to

23 P.G. Grzybowski, Edukacja europejska..., op.cit., s. 68.

24 W. Frankiewicz, K. Kossak-Główczewski, Edukacja regionalna..., op.cit., s. 59-60. 
jednak znajduje ona uznanie i przejawia się także w praktyce edukacyjnej" 25 .

Edukacja międzykulturowa. Charakteryzujące ostatnie dekady XX w. i początek XXI stulecia nowe widzenie edukacji w społeczeństwach zróżnicowanych kulturowo wiąże się z pozytywną ewolucją modelu edukacji wielokulturowej i podejmowaniem prób zastępowania go nowym, opartym na odmiennej aksjologii i polityce społecznej, wynikającej z dostrzegania potrzeb oraz oczekiwań jednostek i grup. U zarania edukacji międzykulturowej spoczywają więc szczególnie negatywne, niespełniające oczekiwań doświadczenia z edukacją wielokulturową oraz jej skutkami w praktyce społecznej. Oparta na ideologii międzykulturowości edukacja stanowi specyficzny model działalności społecznej, kulturalnej i oświatowej, uwzględniający wzajemne poznawanie, rozumienie i wzbogacanie kultur oraz każdego człowieka tworzącego tą kulturę. Jej istotną cechą stało się otwarcie na Innych/Obcych i ich problemy. W przeciwieństwie do edukacji wielokulturowej, zmierzającej ku asymilacji mniejszości, przez jej podporządkowanie grupie dominującej i utrzymanie statycznego status quo, skutkiem edukacji międzykulturowej ma być integracja i dynamizacja społeczno-kulturowa różnych kręgów społecznych, oparta na wzajemnym zbliżeniu ich członków ${ }^{26}$. W takich okolicznościach dzięki dialogowi, wzajemnemu poznaniu i zbliżeniu mają powstawać warunki do przekazywania oraz akceptacji i przejmowania najbardziej wartościowych elementów kultur, stykających się jednostek i grup. Sprzyja to ich współpracy w różnych dziedzinach życia, przy jednoczesnym prawie do zachowania odrębności ${ }^{27}$.

25 P.G. Grzybowski, Edukacja europejska..., op.cit., s. 75.

26 Ibidem, s. 76.

27 T. Lewowicki, W poszukiwaniu modelu edukacji międzykulturowej, [w:] Edukacja międzykulturowa w Polsce i na świecie, red. T. Lewowicki, E. Ogrodzka-Mazur, A. Szczurek-Boruta, Katowice 2000, s. 26. 
Jerzy Nikitorowicz definiuje edukację międzykulturową jako:

„[...] ogół wzajemnych wpływów i oddziaływań jednostek i grup, instytucji, organizacji, stowarzyszeń, związków, sprzyjających takiemu rozwojowi człowieka, aby stawał się on w pełni świadomym i twórczym członkiem wspólnoty rodzinnej, lokalnej, regionalnej, wyznaniowej, narodowej, kontynentalnej, kulturowej i globalnej - planetarnej oraz był zdolny do aktywnej samorealizacji własnej, niepowtarzalnej i trwałej tożsamości i odrębności”28.

Warunkiem powstania takiego społeczeństwa jest mobilizacja wielu sił: społecznych, ekonomicznych, politycznych, ale przede wszystkim przemiana mentalności osób uczestniczących w kontaktach zróżnicowanych środowisk. Ważną rolę w kształtowaniu wizji i praktyki społecznej w ramach edukacji międzykulturowej odgrywa państwo i jego struktury władzy. Oprócz polityki rządów podstawowym warunkiem powodzenia programów edukacji międzykulturowej jest przyzwolenie społeczne na ten proces. Wobec powyższego edukacja międzykulturowa nie jest idealnym modelem, łatwym do zaakceptowania przez wszystkich i do zrealizowania gdziekolwiek. Wiąże się ona z licznymi dylematami i koniecznością dokonywania wyborów. Z założenia edukacja międzykulturowa powinna mieć miejsce we wszystkich warstwach społeczeństwa. Należy podkreślić, że model edukacji międzykulturowej mimo niewątpliwej aktualności (w końcu nadal znajduje się w fazie ewolucyjnego tworzenia) również staje się przedmiotem krytyki.

Atrakcyjność edukacji międzykulturowej polega na przywracaniu wiary w człowieka, jego moc wewnętrzną i wrażliwość na potrzeby innych. U jej podstaw spoczywa pełna humanistycznej głębi idea współistnienia, zakładająca możliwość wzajemnego

28 J. Nikitorowicz, Wartości etnosu..., op.cit., s. 9. 
rozwoju w wyniku dokonujących się procesów wewnętrznych, dialogu, porozumienia, negocjacji i współpracy ${ }^{29}$.

\section{Różnice kulturowe w Azji w pigułce}

Różnice kulturowe w komunikacji dotyczą nie tylko języka, ale także sfery niewerbalnej. Uczeń początkowo może błędnie odczytywać pewne sygnały, takie jak gesty czy mimika. Podobnie nauczyciele mogą w sposób nieadekwatny ocenić zachowanie ucznia pochodzącego na przykład z Azji, którego reakcją na zwrócenie mu uwagi przez nauczyciela będzie uśmiech, a nawet śmiech. Podczas gdy w Polsce uśmiech oznacza zadowolenie - Azjaci często kryją za nim wstyd czy zażenowanie. Również kontakt wzrokowy, który w naszej kulturze jest oznaką szczerości intencji, a opuszczenie wzroku może sugerować chęć zatajenia prawdy - w Azji stanowi wyraz szacunku ${ }^{30}$.

$\mathrm{Z}$ doświadczeń nauczycieli pracujących z dziećmi pochodzenia azjatyckiego wynika, że sporo trudności sprawiają dzieciom pytania związane $\mathrm{z}$ adresem zamieszkania i imionami rodziców. Bywa, że przyczyną zakłopotania jest również konieczność udzielenia odpowiedzi na z pozoru proste pytanie: Jak masz na imię? Kłopoty te mogą być związane z przekonaniem panującym w niektórych kulturach Wschodu - w tym krajów azjatyckich, arabskich, w kulturach kaukaskich, czyli kulturach kolektywistycznych, że tym, co więcej mówi o człowieku jest jego nazwisko. Świadczy ono o przynależności do grupy, rodziny, klanu - a ta przynależność stanowi większą wartość niż cecha indywidualna, jaką jest imię. Na przykład w kulturze wietnamskiej w komunikacji codziennej - w pra-

29 P.G. Grzybowski, Edukacja europejska..., op.cit., s. 90.

30 K. Białek (red.), Międzykulturowość w szkole. Poradnik dla nauczycieli i specjalistów, Warszawa 2015, s. 20. 
cy, szkole, a nawet w domu - rzadko używa się imion ${ }^{31}$. W językach państw, w których obowiązują takie zasady, istnieje wiele form zwracania się do innej osoby, np. mistrzu - do nauczyciela, opiekunie - do starszego brata, młodsza córko - do młodszej córki. Ponadto w kulturze wietnamskiej imię prawie zawsze ma jakieś znaczenie - nadawane jest na przykład w nawiązaniu do pogody, jaka panowała właśnie w dniu urodzin dziecka; może też być nadane tak, by rymowało się z imieniem starszego dziecka. W Chinach czy Wietnamie imię jest prywatną i intymną sferą człowieka, często jedynie matki mają przywilej zwracania się do dziecka, używając jego imienia. Wynika to między innymi z kolektywnych wartości kultur azjatyckich, gdzie grupa jest ważniejsza od jednostki; hierarchia podtrzymuje porządek społeczny i harmonię w grupie, a tytułowanie każdej osoby zgodnie z pełnioną przez nią rolą społeczną wpływa na zachowanie hierarchii ${ }^{32}$.

Różnice występujące w społeczeństwach odmiennych kulturowo widoczne są również w sposobie podejścia do nauki oraz usytuowaniu edukacji w systemie wartości danej kultury. W państwach azjatyckich edukacja jest niezwykle ceniona ze względu na możliwości osiągnięcia ważnej pozycji w hierarchii społecznej. Przykładowo uczniowie pochodzenia chińskiego lub wietnamskiego, uczęszczający do polskiej szkoły, z reguły pilnie się uczą i są zaangażowani w życie szkolne, otrzymują bardzo dobre oceny, a ich osiągnięcia szczególnie widać w wynikach testów językowych (dyktanda) oraz matematycznych ${ }^{33}$.

Jeszcze inna odmiana wielokulturowości została ukształtowana w niektórych państwach Azji i Półwyspu Arabskiego.

31 K. Białek, H. Dang Thu, E. Grabowska, T. Halik, T. Ngo Van, Edukacja dzieci i młodzieży wietnamskiej w Polsce. Praktyczny miniprzewodnik, Warszawa 2009.

32 K. Białek (red.), Międzykulturowość w szkole..., op.cit., s. 21.

33 Ibidem, s. 21-22. 
Zróżnicowanie narodowościowe i etniczne jest tam spowodowane potrzebami rynku pracy. Ludność napływowa stanowi dużą część populacji danego państwa, np. w Kuwejcie czy w Katarze rdzenni mieszkańcy stanowią mniejszość. Dobrobyt rdzennych mieszkańców tzw. naftowych państw arabskich w dużej mierze jest wynikiem pracy przybyszów z Indii, Pakistanu i innych państw. Przybysze ci z trudem uzyskują prawa obywatelskie i stanowią głównie siłę roboczą, w dużej części funkcjonują na marginesie życia społecznego, w bardzo złych warunkach. Wykonują niemal niewolniczą pracę. To rodzaj wielokulturowości niemal kastowej, charakteryzującej się niesprawiedliwością społeczną i wyzyskiem. W państwach Azji są różne odmiany wielokulturowości - od zgodnego współżycia, oswojenia wielokulturowości - do konfliktów ludzi różnych kultur, wojen, ludobójstwa ${ }^{34}$.

\section{Podsumowanie}

Występowanie efektu pogranicza w edukacji staje się wręcz koniecznością, bowiem tylko ta cecha pozwala na uświadomienie człowiekowi obecności w jego otoczeniu Innych/Obcych, a także faktu, że on sam może być rozpatrywany jako jeden z nich.

Pogłębiającego się zróżnicowania kulturowego społeczeństw nie da się uniknąć. Aby ułatwić radzenie sobie z nim, środowiska postępowe podejmują m.in. działania edukacyjne, których efektem ma być nie tylko pomoc w rozwiązywaniu bieżących problemów, ale także przygotowanie obecnych i przyszłych pokoleń do życia w społeczeństwach charakteryzujących się coraz częstszymi, świadomymi kontaktami z odmiennością. Perspektywa ta pozwala przypuszczać, że wzrośnie społeczne zapotrzebowanie

34 Por. T. Lewowicki, Wielokulturowość i globalizacja..., op.cit., s. 17. 
na opracowania naukowe poświęcone zróżnicowaniu kulturowemu, zwłaszcza dotyczące edukacji jako mającej na celu m.in. ułatwienie integracji społeczno-kulturowej mieszkańców całego świata, w tym także Azji ${ }^{35}$.

Jak zauważa Nikitorowicz, odwieczny problem stanowią relacje i komunikacje między kulturami, które albo rozwijały się dzięki wzajemnym zapożyczeniom, albo się ze sobą ścierały i wyniszczały. Kultura kształtuje wszak pewien horyzont, który może ograniczać się do określonego kanonu ducha i świadomości odrębności, ale może także otwierać się na Inność/Obcość i rozwijać się dzięki zapożyczeniom ${ }^{36}$.

Wnioski wynikające z analizy koncepcji edukacji, budowanych w środowiskach mających doświadczenie z dużym zróżnicowaniem kulturowym, potrafią być przydatne np. osobom bezpośrednio związanym z działalnością edukacyjną, podmiotom rozwiązującym problemy społeczne w środowiskach lokalnych, a także jednostkom i grupom, którym szeroko pojęta edukacja sprawia trudności. Wiedza ta umożliwi postrzeganie z szerszej perspektywy własnych doświadczeń i potencjalne wzbogacenie działań o nowe treści, formy, metody itp. Pomoże także stwierdzić przyczyny niepowodzeń i być może w związku z tym skłoni odpowiednio wcześnie do odejścia od rozwiązań, które nie sprawdziły się w podobnych przypadkach. A może najważniejsze - pozwoli również zwrócić uwagę na te treści i formy działalności edukacyjnej, które, pomagając osłabić napięcia i konflikty - wynikające ze zróżnicowania kulturowego - uzyskały aprobatę społeczną, a więc w pełni zasługują na upowszechnienie oraz doskonalenie przy wsparciu naukowców ${ }^{37}$.

35 P.G. Grzybowski, Edukacja europejska..., op.cit., s. 11-12.

36 Ibidem, s. 83.

37 Ibidem, s. 12. 
Edukacja wielokulturowości i międzykulturowości na kontynencie azjatyckim w niczym nie odbiega od podobnych zjawisk występujących na całym świecie, a wpływ tych zjawisk w niczym nie jest ani większy, ani mniejszy niż gdzie indziej. Są tylko pewne zjawiska, zachowania, które charakteryzują konkretne miejsce na kuli ziemskiej, np. wychowanie dzieci, nauka itp., które mogą stwarzać często wyimaginowane problemy przy relacjach społecznych, wynikające z braku zrozumienia, a czasem nawet leku. Tak naprawdę to wielokulturowość staje się społecznym bogactwem, a nie problemem, ale tego należy się nauczyć (wyedukować). Punktem wyjścia dyskusji nad wielokulturowością powinien być stan świadomości ludzi. Wielokulturowość to wyraz zerwania z praktyką zniewolenia, opresji i podporządkowania powszechnie stosowaną w dziejach przez dominującą większość wobec różnego rodzaju mniejszości (przede wszystkim etnicznych i religijnych), a także z ideologią i praktyką asymilacjonizmu, która była niesprawiedliwa wobec grup zmuszanych do asymilacji. Praktyka społeczna wielokulturowości ukazuje możliwości bycia człowiekiem na inny sposób niż nasz, co może nas skłonić do krytycznej refleksji wobec samych siebie, a następnie do ewentualnej zmiany, ale trzeba tego chcieć...

\section{Bibliografia}

Baczkowski K., Idea jedności europejskiej w średniowieczu, [w:] $Z$ dziejów prób integracji europejskiej. Od średniowiecza do współczesności, „Zeszyty Naukowe Uniwersytetu Jagiellońskiego" 1995, nr MCLXXVII5.

Barska A., Korzeniowski M. (red.)., Wielokulturowość, międzykulturowość, transkulturowość w perspektywie europejskiej i pozaeuropejskiej, Opole 2007. 
Białek K. (red.), Międzykulturowość w szkole. Poradnik dla nauczycieli i specjalistów, Warszawa 2015.

Białek K., Dang Thu H., Grabowska E., Halik T., Ngo Van T., Edukacja dzieci i mtodzieży wietnamskiej w Polsce. Praktyczny miniprzewodnik, Warszawa 2009.

Chołaj H., Kolumb, Europa i świat, Warszawa 1995.

Davies N., Europa - rozprawa historyka $z$ historia, tłum. E. Muskat-Tabakowska, Kraków 1998, s. 31-41.

Drelich-Skulska B., "Wartości azjatyckie” jako próba stworzenia podstaw tożsamości narodów Azji Wschodniej, „Prace Naukowe Akademii Ekonomicznej we Wrocławiu" 2007, nr 1173: Integracja a globalizacja.

Frankiewicz W., Kossak-Główczewski K., Edukacja regionalna $i$ alternatywna. Założenia i program pierwszego Podyplomowego Studium Edukacji Regionalnej i Alternatywnej w Uniwersytecie Gdańskim, [w:] Spoteczności pogranicza, wielokulturowość, edukacja, red. T. Lewowicki, B. Grabowska, Cieszyn-Warszawa 1996.

Gęsiak L., Wielokulturowość: rola religii w dynamice zjawiska, Kraków 2007.

Grzybowski P.G., Edukacja europejska - od wielokulturowości do międzykulturowości, Kraków 2009.

Grzybowski P.G., Edukacja w warunkach zróżnicowania kulturowego, „Przegląd Pedagogiczny” 2007, nr 1.

Kossak-Główczewski K., Edukacja regionalna, wielokulturowa i międzykulturowa a pytanie o "prywatne ojczyzny” - zarys problemu, [w:] Rodzina wobec wyzwań edukacji międzykulturowej, red. J. Nikitorowicz, Białystok 1997.

Kuczyński J., Młodość Europy i wieczność Polski, Warszawa 1999.

Kwieciński Z., Przedmowa, [w:] Pedagogika - podręcznik akademicki, t. 1, red. Z. Kwieciński, B. Śliwerski, Warszawa 2003. 
Kwieciński Z., Socjopatologia edukacji, Olecko-Białystok 1995.

Lewowicki T., W poszukiwaniu modelu edukacji międzykulturowej, [w:] Edukacja międzykulturowa w Polsce i na świecie, red. T. Lewowicki, E. Ogrodzka-Mazur, A. Szczurek-Boruta, Katowice 2000.

Lewowicki T., Wielokulturowość i globalizacja a strategie edukacji międzykulturowej, „Pogranicze. Studia Społeczne” 2015, t. XXV, s. 13-24.

Marszałek-Kawa J., Kaja E. (red.), W poszukiwaniu azjatyckiej tożsamości. Dylematy i wyzwania, Toruń 2014.

Nikitorowicz J., Pogranicze, tożsamość, edukacja międzykulturowa, Białystok 1995.

Nikitorowicz J., Wartości etnosu jako podstawa kształtowania tożsamości wielokulturowej, podtoże konfliktów kulturowych i cel edukacji międzykulturowej, [w:] Świat wartości i edukacja międzykulturowa, red. T. Lewowicki, E. Ogrodzka -Mazur, A. Gajdzica, Cieszyn-Warszawa 2003.

Sadowski A., Charakter międzyetnicznego wspótżycia na polsko-biatoruskim pograniczu, [w:] Edukacja międzykulturowa. W kręgu potrzeb, oczekiwań i stereotypów, red. J. Nikitorowicz, Białystok 1995.

Śliz A., Szczepański M., Wielokulturowość: konflikt czy koegzystencja?, Warszawa 2011.

Van der Maren J.-M., La recherche appliquée en pédagogie. Des modèles pour l'enseignement, Paris-Bruxelles 1999.

\section{Źródla internetowe}

Edukacja międzykulturowa, Encyklopedia PWN, https:// encyklopedia.pwn.pl/haslo/edukacja-miedzykulturowa;3896549.html. 


\begin{abstract}
Abstrakt
Wielokulturowość jest odwiecznym zjawiskiem. Dzieje ludzkości wypełnione są przykładami mnogości języków, kultury - społeczności żyjących w bliskich nam i odległych regionach świata. Odrębność społeczna w wyglądzie, zwyczajach, wierzeniach, językach - i w wielu innych zagadnieniach - zazwyczaj budziły ciekawość, innym razem lęk, ale wraz z rozwojem cywilizacji, globalizacji i coraz częstszymi kontaktami $\mathrm{z}$ „innymi”, przestaje dziwić i staje się zjawiskiem naturalnym. Edukacja międzykulturowa jest to koncepcja pedagogiczna, której celem jest poszerzanie własnej tożsamości jednostkowej i społecznej przez kontakt z innymi kulturami, kształtowanie rozumienia odmienności kulturowych, wyzbywanie się uprzedzeń i stereotypów. Rozpatrując Azję jako pogranicze kulturowe, koncepcje edukacji azjatyckiej można sytuować w modelach edukacji wielokulturowej lub międzykulturowej, różniących się w podstawach aksjologicznych i ideologicznych oraz w zakładanych celach, treściach i formach oddziaływania edukacyjnego.
\end{abstract}

Słowa kluczowe: Azja, wielokulturowość, międzykulturowość, odrębność, emigrant, edukacja

\begin{abstract}
Multiculturalism is an eternal phenomenon. The history of mankind is filled with examples of a multitude of languages, culture - communities living in close and distant regions of the world. Social distinction in appearance, customs, beliefs, languages - and in many other issues - usually aroused curiosity, sometimes fear, but with the development of civilization, globalization and more and more frequent contacts with "others", it is not surprising and it becomes a natural phenomenon. Intercultural education - a pedagogical concept whose aim is to broaden one's own individual and social identity through contact with other cultures, to shape the understanding of cultural differences, to eliminate prejudices and stereotypes. Considering Asia as a cultural border, concepts of Asian education can be placed in multicultural or intercultural education models, differing in axiological and ideological foundations and in the assumed goals, contents and forms of educational impact.
\end{abstract}

Keywords: Asia, multiculturalism, interculturality, separateness, emigrant, education 


\section{Anna Brzezińska-Rybicka}

Katolicki Uniwersytet Lubelski im. Jana Pawła II

ORCID ID: https: / / orcid.org/0000-0003-4259-1913

\section{Edukacja w systemie penitencjarnym Azji na przykładzie wybranych państw}

„Człowiek i jego czyny to dwie różne sprawy.

Chociaż dobry uczynek zasługuje na aprobatę, a zły na osąd, to człowiek czy dobry czy zły czyn popełnił, zawsze zasługuje na szacunek lub współczucie"

Mahatma Gandhi

\section{Wstęp}

Edukacja stanowi jeden z podstawowych obszarów działalności każdego człowieka, a jednocześnie jest jego powinnością obywatelską ${ }^{1}$. Selekcja szkolna (np. złe, czasem niesprawiedliwe oceny, egzaminy) może stać się jednym z determinantów wykluczenia w życiu dorosłym ${ }^{2}$, warunkującym znalezienie dobrej pracy, aktywności obywatelskiej, pozycji społecznej, pozycji w życiu kulturalnym itp. Z marginalizacją tą wiąże się często brak szacunku ze strony społeczeństwa, co prowadzi do szukania go w gronie podobnych sobie. Niepowodzenia szkolne wytrącają młodych ludzi poza ramy edukacji, uniemożliwiają posiadanie i realizację ambicji edukacyjnych, co często

1 Por. M. Winiarski, Wykluczenie społeczne dzieci i młodzieży - prorodzinne formy przeciwdziałania, „Pedagogika Społeczna” 2008, nr 2 (28), s. 22.

2 Ibidem. 
wiedzie do patologizacji życia, a w konsekwencji - zejścia na drogę przestępstwa i pobytu w zakładzie karnym ${ }^{3}$.

Państwa azjatyckie i europejska Finlandia od lat przodują w międzynarodowych rankingach systemów edukacji. Uczniowie $\mathrm{z}$ tych państw osiągają ponadprzeciętne wyniki w testach kompetencji, a praca w zawodzie nauczyciela to prawdziwy prestiż. „W czym tkwi sukces najlepszych systemów edukacji na świece? Czy edukacja więźniów w państwach azjatyckich też się tak wyróżnia?"

Osoby odbywające karę pozbawienia wolności często wykazują znaczne opóźnienia w nauce. Nauka sprawia im niezwykłą trudność, wynikającą nie tyle z poziomu intelektualnego, ile zaniedbań edukacyjnych szkoły i rodziny. Do podstawowych celów nauki podejmowanej w zakładzie karnym należy uzupełnienie braków w wykształceniu oraz przygotowanie do zawodu, co (przynajmniej w teorii) ma pomóc skazanemu w znalezieniu pracy na wolności po odbytym wyroku. Nie mniej ważne są jednak cele podmiotowe, zmierzające do podniesienia samooceny skazanych, zwłaszcza tych, którzy pomimo posiadania wykształcenia podstawowego nie potrafią czytać ani pisać ${ }^{4}$

Wzorcowe reguły zachowania z więźniami Organizacji Narodów Zjednoczonych (ONZ) traktują osadzonych jako jednostki będące częścią tego samego społeczeństwa, które funkcjonuje poza murami instytucji penitencjarnych. W myśl tych reguł powrót więźniów do życia w społeczeństwie powinien stać się łatwiejszy, poprzez zapewnienie im możliwości edukacji, którą będzie można kontynuować także po wyjściu na wolność, po zwolnieniư

3 Por. A. Jaworska, Rola edukacji w resocjalizacji instytucjonalnej, [w:] eadem, Leksykon resocjalizacji, Kraków 2012, s. 323-327.

4 Ibidem.

5 T. Zaiczenko, Szansa na lepszą przyszłość. Edukacja dorostych w sys- 
Rezolucja 2015/20 Rady Ekonomicznej i Społecznej Organizacji Narodów Zjednoczonych (reguła 104) mówi w następujących słowach o edukacji w więzieniach:

1. „Zapewni się możliwość dalszej edukacji wszystkim więźniom, którzy będą w stanie odnieść z tego korzyść, włączając w to także naukę religii w krajach, w których jest to możliwe. Kształcenie analfabetów oraz młodych więźniów będzie obowiązkowe, na co administracja zakładu karnego będzie zwracała szczególną uwagę.

2. W takim stopniu, jak to możliwe edukacja więźniów będzie zintegrowana z systemem edukacyjnym kraju, tak, aby po zwolnieniu mogli oni bez trudności kontynuować edukację"6.

Tatiana Zaiczenko z Regionalnego biura DVV International $^{7}$ w Azji Środkowej podaje, że w dwóch państwach Azji

temie penitencjarnym Azji Środkowej, „Andragogy Yearbook” 2013, nr 20, s. 344 .

6 Sesja XVII, Zapobieganie przestępstwom i wymiar sprawiedliwości w sprawach karnych, rezolucja ONZ 2015/20 Wzorcowe reguły minimalne Organizacji Narodów Zjednoczonych dotyczące postępowania z więźniami (Reguły Mandeli). Por. „77. (1) Zapewni się możliwość dalszej edukacji wszystkim więźniom, którzy będą w stanie odnieść z tego korzyść, włączając w to także naukę religii, w krajach, w których jest to możliwe. Kształcenie analfabetów oraz młodych więźniów będzie obowiązkowe, na co administracja instytucji o charakterze izolacyjnym będzie zwracała szczególną uwagę. (2) W takim stopniu jak to możliwe edukacja więźniów będzie zintegrowana z systemem edukacyjnym kraju, tak aby po zwolnieniu mogli oni kontynuować edukację bez trudności", Wzorcowe reguły minimalne postępowania z więźniami. Przyjęte w Genewie w 1955 r. przez Pierwszy Kongres Narodów Zjednoczonych w Sprawie Zapobiegania Przestępczości i Postępowania ze Sprawcami Przestępstw i zaaprobowane przez Radę Gospodarczą i Społeczną w rezolucji 663C (XXIV) z dnia 31 lipca 1957 r. oraz 2076 (LXII) z dnia 13 maja 1977 r., https://bip.ms.gov.pl/Data/Files/_public/bip/ prawa_czl_onz/prawa_czlow_26_1.doc [dostęp: 15.04.2019].

7 Instytut Współpracy Międzynarodowej Niemieckiego Związku Uniwersytetów Ludowych. Na całym świecie DVV International współpracuje z ponad 200 partnerami w ponad 40 państwach Afryki, Azji, Ameryki Łacińskiej i Europy z gospodarką przejściową. W Azji Środkowej biura regionalne funkcjonują w Uzbekistanie, Kirgistanie, Tadżykistanie. DVV International 
Środkowej - Uzbekistanie i Kirgistanie już od kilku lat prowadzone są projekty dotyczące edukacji zawodowej skazanych, podwyższenia kwalifikacji pracowników zakładów karnych (nauczyciele szkół zawodowych i funkcjonariuszy/oficerów), psychologicznego i prawnego wsparcia zwolnionych. W 2014 r. podobny projekt rozpoczął się w Republice Tadżykistanu8.

Celem artykułu będzie próba pokazania podstawowych problemów edukacyjnych w systemie penitencjarnym wybranych krajów Azji, w oparciu o badania Tatiany Zaiczenko oraz inne materiały, dostępne w polskiej i światowej literaturze przedmiotu.

\section{Prezentacja badań Tatiany Zaiczenko}

Systemy penitencjarne Uzbekistanu, Tadżykistanu, a także Republiki Kirgiskiej borykają się z tymi samym zestawem problemów, z którymi zmagają się systemy w innych, zniszczonych krajach po rozpadzie Związku Radzieckiego, a to m.in: niedostateczne zabezpieczenie materialne, zawiłość podziału i kontroli społeczeństwa więziennego, niedostateczne wykształcenie personelu więziennego, czy też brak możliwości jego uzupełniania, zgodnie z wymogami współczesnego systemu penitencjarnego. ${ }^{9}$

W Uzbekistanie projekt rozpoczął się w $2003 \mathrm{r}$. Na początkowym etapie realizacji projektu grupę docelową stanowiły tylko skazane kobiety, spośród których wiele nie zdążyło na

postrzega siebie jako profesjonalnego partnera, który wnosi swoją wiedzę i doświadczenie do wspólnych projektów i skupia się na zrównoważonej współpracy z organizacjami społecznymi i instytucjami państwowymi. Szczegółowe informacje na temat opisywanej organizacji i jej działalności znaleźć można na stronie DVV International: www.dvv-international.de i www.dvv-international.uz [dostęp: 15.04.2019].

8 T. Zaiczenko, Szansa..., op.cit., s. 343-353.

9 Ibidem, s. 348. 
wolności otrzymać należytego wykształcenia, ani zawodu i posiadało niewielkie przygotowanie do pracy zawodowej. Celem głównym projektu było wsparcie dążenia skazanych do powrotu do wartościowego społecznie stylu życia poprzez przekwalifikowanie, kształcenie podstawowe skierowane na uzyskanie zawodu. Po przeprowadzeniu badania zostały określone kierunki, w których kobiety chciałyby się kształcić. Dodatkowo przy tworzeniu programów edukacji zawodowej skazanych kobiet brano pod uwagę: poziom posiadanej wiedzy ogólnej, wiek, specyfikę posiadanego doświadczenia zawodowego ${ }^{10}$.

Przez lata realizacji projektu w zakładach karnych około tysiąca skazanych kształciło się na określonych kursach zawodowych (fryzjerstwo, obsługa komputera, szycie, fotografika, dziewiarstwo i sztuka użytkowa, cukiernictwo itp.). Głównym kryterium doboru uczestniczek kursów była zasada dobrowolności. W proces edukacji kobiet zostali włączeni zaproszeni trenerzy i nauczyciele szkoły zawodowej. Poszczególne bloki tematyczne prowadziły również same skazane posiadające dobre przygotowanie zawodowe w danym zakresie i wcześniejsze doświadczenie w nauczaniu. Uzyskanie nowych kwalifikacji zarówno dla skazanych uczących się, jak i dla tych, które nauczały, okazało się ważnym środkiem podnoszenia/podwyższania poczucia własnej wartości. Główne zadanie nauczycieli biorących udział w projekcie było stopniowe wszczepianie kobietom artystycznego smaku oraz ujawnienie u nich potencjału twórczego poprzez stworzenie im po zwolnieniu warunków przystosowania się do nowych realiów życia. Szkolenia takie pomagają w przywróceniu umiejętności komunikacyjnych, usuwaniu wewnętrznych barier oraz rozwijaniu sfery psychoemocjonalnej szkolonej jednostki. Od 2013 r. rozpoczęto prace dotyczące edukacji zawodowej, także w męskich zakładach,

10 Ibidem, s. 345. 
których celem było podniesienie wiary w siebie, we własne siły, w możliwość rozpoczęcia nowego życia po zwolnieniu. Formowanie umiejętności słuchania i słyszenia - to podstawowa funkcja tych seminariów, aby do społeczeństwa powracali ludzie, którzy będą mogli znaleźć swoje miejsce w życiu, naprawić/odbudować utracone więzi społeczne ${ }^{11}$.

Przeprowadzone badanie dowiodło, że dzięki uczestnictwu w kursach zawodowych i edukacyjnych $70 \%$ skazanych miało nadzieję uzyskać zawód, 50\% - psychologicznie ułatwić sobie pobyt w zamknięciu, $40 \%$ - poczuć się bardziej pewnym siebie. Skuteczność przeprowadzonych działań oceniana jest na bieżąco przez to, jak wygląda życie byłego skazańca po zwolnieniu. Powszechnie wiadomo, że odbywanie kary w formie pozbawienia wolności związane jest z szeregiem negatywnych czynników, które utrudniają ponowną adaptację do funkcjonowania w społeczeństwie, w tym np.: im dłuższy wyrok, tym trudniejszy jest ten proces. Życie zmienia się na tyle szybko, że ludzie, którzy spędzili kilka lat w zamknięciu, po zwolnieniu trafiają $\mathrm{w}$ zupełnie nowe środowisko: $\mathrm{z}$ nowymi prawami, innym poziomem życia, zmienionymi wartościami społecznymi ${ }^{12}$.

Zadaniem projektu było także podniesienie kwalifikacji personelu instytucji penitencjarnych (nauczycieli szkół zawodowych i ogólnokształcących oraz funkcjonariuszy). Zwiększenie kwalifikacji personelu zostało przeprowadzone $\mathrm{z}$ użyciem skutecznych współczesnych metod uczenia (się) ludzi dorosłych $^{13}$.

Od marca 2012 r. w Kirgistanie dzięki pomocy finansowej Unii Europejskiej w ramach linii programowej: „Wsparcie re-

\footnotetext{
11 Ibidem, s. 346-347.

12 Ibidem.

13 Ibidem, s. 347-348.
} 
formy systemu penitencjarnego w Republice Kirgiskiej", rozpoczęła się realizacja projektu »SZANSA« (Edukacja dorosłych w systemie penitencjarnym: szansa na lepszą przyszłość). Przedmiotowy projekt miał w założeniu przyczynienie się do procesu liberalizacji systemu penitencjarnego, za pomocą edukacji dorosłych, poprzez wsparcie procesu rehabilitacji skazanych do życia w społeczeństwie, dzięki możliwości zdobycia wykształcenia zawodowo-technicznego, zdobycie doświadczenia praktycznego i rozszerzenie kompetencji pracowników w zakładach pilotażowych. Po zakończeniu szkolenia wszystkim uczestnikom grup projektowych zostały wręczone certyfikaty, na które naprawdę zasłużyli, i które w przyszłości (taka jest nadzieja) pomogą im łatwiej znaleźć pracę. W ramach projektu, oprócz szkolenia zawodowego, prowadzone były kursy dotyczące rozwoju umiejętności życiowych skazanych, które okazały się nie mniej popularne. Skazani otrzymali wiedzę, niezbędną zarówno do życia w zakładach karnych, jak również po zwolnieniu, otrzymali wsparcie psychologiczne, informacje dotyczące: prawodawstwa, poszukiwania pracy, przygotowania dokumentów, rejestracji w charakterze bezrobotnych itd. ${ }^{14}$

\section{Konkluzje końcowe}

Kwestie problemów więźniów odbywających karę pozbawienia wolności, w tym ich stygmatyzacji, skutków odbywania kary w miejscu odosobnienia, roli edukacji w systemie penitencjarnym opisuje szeroko wielu naukowców, do których zaliczyć należy m.in. Kazimierza Pierzchałę, wieloletniego kapelana więziennego ${ }^{15}$.

14 Ibidem, s. 348-350.

15 Por. m.in.: K. Pierzchała, Przestępstwo. Probacja alternatywa dla kary pozbawienia wolności, „Probacja” 2011, nr 4, s. 5-26; idem, Kapelan więzienny w procesie resocjalizacji penitencjarnej, Toruń 2013; idem, Skazani 
Edukacja jest jednym z oddziaływań resocjalizacyjnych na skazanych i w swej istocie polega na celowym i świadomym oddziaływaniu - na mających problemy z prawem - osoby. W tej kwestii nie ma różnicy co do miejsca na świecie. Celem tych oddziaływań z założenia powinno być przygotowanie więźniów do pełnienia konstruktywnych ról społecznych tak, by spełniali oni społeczne oczekiwania ${ }^{16}$. W odróżnieniu od powszechnych szkół, szkoła przywięzienna kładzie nacisk na funkcję resocjalizującą szkoły. Obowiązkiem nauczyciela w takich szkołach jest korygowanie i kompensowanie zaburzonych postaw i struktur osobowości ${ }^{17}$.

$\mathrm{Z}$ reguły osoby po zwolnieniu z zakładów penitencjarnych spotykają się z problemem zatrudnienia, a w zakładach tych uwidacznia się oderwanie od normalnego trybu życia, brak perspektyw życiowych i możliwości zmiany czegokolwiek. Podniesienie statusu społecznego każdego człowieka, w tym zwolnionego skazanego, pociąga za sobą zmiany w zachowaniu, buduje wiarę w swoje siły, a przede wszystkim prowadzi do zrozumienia tego, że podejmowanie wysiłków prowadzi do

ale nie potępieni, wyd. II rozszerzone, Torun 2015; idem, The process of social reintegration of convicts on the background of world penitentiary system. The analytical and synthetic outline of the issue [Proces readaptacji spotecznej skazanych na tle światowego systemu penitencjarnego. Zarys analitycznosyntetyczny zagadnienia], "Polish Political Science. Yearbook” 2015, vol. 44, s. 154-170; idem, Destygmatyzacja przestępców w świetle Magisterium Kościoła oraz poglądów na resocjalizację, Kraków 2016; idem, Pedagogical and Theological Reflections on the De-Stigmatization Process, [Refleksje pedagogiczno-teologiczne nad procesem destygmatyzacji], „Resocjalizacja Polska”/ „Polish Journal of Social Rehabilitation” 2017, vol. 13; idem, Możliwości ksztatcenia ustawicznego stużby więziennej oraz osadzonych, [w:] Ksztatcenie ustawiczne. Wymiar interdyscyplinarny, red. E. Stokowska-Zagdan, J. Flanz, Skierniewice 2018, s. 90-98.

16 L. Wawrzyniak, Resocjalizacja w warunkach zaktadu karnego, [w:] Profilaktyka społeczna i resocjalizacja młodzieży, red. B. Urban, Mysłowice 2004, s. 156.

17 A. Szecówka, Kształcenie resocjalizujące, [w:] Resocjalizacja. Teoria i praktyka pedagogiczna, red. B. Urban, J.M. Stanik, Warszawa 2008, s. 263. 
sukcesu zarówno w poszukiwaniu pracy, jak i w rozwiązywaniu istotnych życiowo zadań.

Szkoły przywięzienne pomagają skazanym w rozwoju intelektualnym i rozbudzaniu zainteresowań, a ponadto pomagają one w kształtowaniu pozytywnych cech osobowych. Pomimo faktu, iż w szkołach przywięziennych uczniami są dorośli, a nie dzieci, to szkoły przywięzienne działają kształcąco. Wspólnota uczniów, jaka się zawiązuje, pozwala wielu wyzbyć się tych cech, które m.in. doprowadziły do przestępstwa, a co za tym idzie skazania. Pozwala na coraz to większe zdobywanie dojrzałości zawodowej i życiowej, uczy rywalizacji i pracy zespołowej. Pozwala powrócić do społeczeństwa i w nim funkcjonować zgodnie z obowiązującymi normami.

Zakłady karne w zaprezentowanych państwach Azji Środkowej posiadają zróżnicowane i niejednoznaczne doświadczenie na gruncie przygotowania zawodowego skazanych. Nie ma jednak wątpliwości, że edukacja daje skazanym dodatkową możliwość pozostania sobą w warunkach izolacji od społeczeństwa, przyczynia się do rozwoju zdolności i umiejętności zawodowych, sprzyja zmniejszeniu antyspołecznych zachowań uczących się, zwiększa szansę na udaną resocjalizację, a więc zmniejsza prawdopodobieństwo recydywy.

„Azjatyckie kraje i europejska Finlandia od lat przodują w międzynarodowych rankingach systemów edukacji." „Z ostatniego rankingu Pearsona "The Learning Curve 2014" wynika, że w pierwszej piątce najlepszych systemów edukacyjnych na świecie znalazły się kolejno: Korea Południowa, Japonia, Singapur, Hongkong i Finlandia”"18. To stwierdzenie „ze wstępu” nie dotyczy jednak wszystkich państw azjatyckich, a szczególnie edukacji przywięziennej. W państwach azjatyckich, powstałych

18 Najciekawsze fakty o najlepszych systemach edukacji na świecie, https://forsal.pl/artykuly/824241,najciekawsze-fakty-o-najlepszych-systemach -edukacji-na-swiecie.html [dostęp: 15.04.2019]. 
po rozpadzie Związku Radzieckiego, praktycznie w każdym aspekcie, nie wyłączając edukacji w systemie penitencjarnym, istnieje wiele zapóźnień, odstępstw od wzorcowych reguł, które w skrócie przedstawiono w artykule.

\section{Bibliografia}

Jaworska A., Rola edukacji w resocjalizacji instytucjonalnej, [w:] A. Jaworska, Leksykon resocjalizacji, Kraków 20127.

Pierzchała K., Destygmatyzacja przestępców w świetle Magisterium Kościoła oraz pogladów na resocjalizację, Kraków 2016.

Pierzchała K., Kapelan więzienny w procesie resocjalizacji penitencjarnej, Toruń 2013.

Pierzchała K., Możliwości kształcenia ustawicznego służby więziennej oraz osadzonych, [w:] Kształcenie ustawiczne. Wymiar interdyscyplinarny, red. E. Stokowska-Zagdan, J. Flanz, Skierniewice 2018, s. 90-98.

Pierzchała K., Pedagogical and Theological Reflections on the De-Stigmatization Process, [Refleksje pedagogiczno-teologiczne nad procesem destygmatyzacji], „Resocjalizacja Polska”/„Polish Journal of Social Rehabilitation” 2017, vol. 13.

Pierzchała K., Przestępstwo. Probacja alternatywa dla kary pozbawienia wolności, „Probacja” 2011, nr 46.

Pierzchała K., Skazani ale nie potepieni, wyd. II rozszerzone, Toruń 2015.

Pierzchała K., The process of social reintegration of convicts on the background of world penitentiary system. The analytical and synthetic outline of the issue, [Proces readaptacji spotecznej skazanych na tle światowego systemu penitencjarnego. Zarys analityczno-syntetyczny zagadnienia], „Polish Political Science. Yearbook” 2015, vol. 44. 
Szecówka A., Kształcenie resocjalizujące, [w:] Resocjalizacja. Teoria i praktyka pedagogiczna, red. B. Urban, J.M. Stanik, Warszawa 2008.

Wawrzyniak L., Resocjalizacja w warunkach zakładu karnego, [w:] Profilaktyka spoteczna i resocjalizacja mtodzieży, red. B. Urban, Mysłowice 2004.

Winiarski M., Wykluczenie społeczne dzieci i młodzieży - prorodzinne formy przeciwdziałania, „Pedagogika Społeczna” 2008, nr 2 (28).

Zaiczenko T., Szansa na lepsza przyszłość. Edukacja dorostych w systemie penitencjarnym Azji Środkowej, "Andragogy Yearbook" 2013, nr 20.

\section{Akty prawne}

Podstawowe zasady traktowania więźniów. Rezolucja Zgromadzenia Ogólnego ONZ 45/111 z dnia 14 grudnia 1990 r.

Sesja siedemnasta, Trzeci Komitet, Punkt porządku obrad 106, Zapobieganie przestępstwom i wymiar sprawiedliwości w sprawach karnych, rezolucja ONZ 2015/20, Wzorcowe reguły minimalne Organizacji Narodów Zjednoczonych dotyczące postępowania z więźniami (Reguły Mandeli).

Wzorcowe reguły minimalne Narodów Zjednoczonych dotyczące środków o charakterze nieizolacyjnym (Zasady Tokijskie). Rezolucja Zgromadzenia Ogólnego ONZ 45/110 z dnia 14 grudnia $1990 \mathrm{r}$.

Wzorcowe reguły minimalne postępowania z więźniami. Przyjęte w Genewie w 1955 r. przez Pierwszy Kongres Narodów Zjednoczonych w Sprawie Zapobiegania Przestępczości i Postępowania ze Sprawcami Przestępstw i zaaprobowane przez Radę Gospodarczą i Społeczną w rezolucji 663C (XXIV) z dnia 31 lipca 1957 r. oraz 2076 (LXII) z dnia 13 maja 1977 r.

Zbiór zasad mających na celu ochronę wszystkich osób pod- 
danych jakiejkolwiek formie aresztowania bądź uwięzienia. Rezolucja Zgromadzenia Ogólnego ONZ 43/173 z dnia 9 grudnia $1988 \mathrm{r}$.

\title{
Źródla internetowe
}

DVV International, www.dvv-international.de i www.dvv-international.uz.

Najciekawsze fakty o najlepszych systemach edukacji na świecie, https://forsal.pl/artykuly/824241,najciekawsze-fakty-o -najlepszych-systemach-edukacji-na-swiecie.html.

\begin{abstract}
Abstrakt
W trzecim wieku rzymski prawnik ${ }^{19}$ stwierdził, że: „Więzienie powinno służyć jedynie jako miejsce zatrzymywania / przetrzymywania / pozbawienia wolności, ale nie karania" ${ }^{20}$. Powrót więźniów do życia w społeczeństwie powinien być łatwiejszy poprzez zapewnienie im możliwości edukacji, która będzie możliwa do kontynuacji także po wyjściu na wolność. Państwa azjatyckie i europejska Finlandia od lat przodują w międzynarodowych rankingach systemów edukacji. Uczniowie z tych państw osiągają ponadprzeciętne wyniki w testach kompetencji. W czym tkwi sukces najlepszych systemów edukacji na świece? Czy edukacja więźniów w państwach azjatyckich też się tak wyróżnia? Edukacja w warunkach izolacji penitencjarnej ukierunkowana jest zazwyczaj resocjalizacyjnie. Jest ona centralnym elementem w systemie rehabilitacji społecznej skazanych. Oznacza to, że jej głównym celem jest przygotowanie jednostki do uczestnictwa w życiu społecznym. W programach edukacyjnych skierowanych do skazanych konieczne jest uwzględnianie specyficznych cech każdego człowieka, zapewnienie możliwości ogólnego rozwoju kulturalnego.
\end{abstract}

Słowa kluczowe: edukacja, Azja, skazany, resocjalizacja, wolność

19 Nazwisko nieznane.
$20 \quad$ T. Zaiczenko, Szansa..., op.cit., s. 343-353. 


\begin{abstract}
In the third century, a Roman lawyer said: "The prison should only serve as a place of detention / detention / imprisonment, but not punishment". The return of prisoners to live in society should be easier by providing them with education opportunities that can be continued even after they are released. For many years, Asian countries and European Finland have been leaders in international education system rankings. Students from these countries achieve above-average results in competence tests, and work in the teaching profession is a real prestige. What is the success of the best education systems for candles? Is the education of prisoners in Asian countries so different? Education - is a central element in the system of social rehabilitation of convicts. In educational programs aimed at convicts, it is necessary to take into account the specific characteristics of each person, providing opportunities for general cultural development.
\end{abstract}

Keywords: education, Asia, convicted, rehabilitation, freedom 


\author{
Mirosława Cylkowska-Nowak \\ Uniwersytet Medyczny im. Karola Marcinkowskiego w Poznaniu \\ ORCID ID: https://orcid.org/0000-0003-0586-9250
}

\title{
Rozwój psychologii szkolnej w Japonii
}

\section{Wstęp}

Szkolnictwo japońskie postrzegane było jako jedno z najlepszych, najefektywniejszych, relatywnie bezpiecznych dla uczniów i nauczycieli w okresie powojennym do lat 80. XX w. Powszechnie akceptowany egalitaryzm, wynikający ze wspólnych narodowych celów, konsensus w sferze wartości społecznych, wysokie osiągnięcia uczniów japońskich w międzynarodowych testach zbudowały obraz idealnego systemowego rozwiązania edukacyjnego. Jednak ta zewnętrzna harmonia kryła „pod powierzchnią” wiele problemów indywidualnych wynikających z pomijania potrzeb i interesów poszczególnych uczniów poprzez podporządkowanie ich celom grupowym klasy, szkoły i sytemu szkolnego ${ }^{1}$. Stopniowe nasilanie się różnorodnych zachowań i praktyk uczniów zrodziło potrzebę stworzenia systemu wsparcia uczniów, rodziców, rodzin, a niekiedy także nauczycieli. Celem pracy jest ukazanie rozwoju psychologii wychowania w Japonii oraz wyłonienia się w jej polu psychologii szkolnej.

1 M. Cylkowska-Nowak, Bullying $w$ edukacji w badaniach porównawczych, [w:] Instytucje edukacyjne - zagrożenia - bezpieczeństwo. Konteksty prawne, społeczne, edukacyjne i zdrowotne, red. B. Wiśniewska-Paź, Toruń 2018, s. 218. 


\section{Psychologia w Japonii - pionierzy, uniwersytety, laboratoria}

Początki psychologii w Japonii wiążą się z wydarzeniami, które miały miejsce w drugiej połowie XIX w. W 1867 r. zakończyła się historyczna era Edo (trwająca od 1603 r. przez ponad 250 lat), okres zamknięcia tego kraju na wpływy zewnętrzne, a w wyniku presji państw zachodnich rozpoczyna się proces westernizacji, który wraz z upływem lat przeradza się w modernizację. Nowa era - Meiji - rozpoczynająca się w 1868 r., w zamyśle „architektów” przewrotu, miała przynieść nowy kształt polityczny, społeczny, kulturowy i gospodarczy Japonii. Początkowa faza westernizacji pozwoliła na czerpanie wzorów z państw zachodnich, z kolei modernizacja oznaczała samodzielne kreowanie kierunków rozwoju, ich testowanie w japońskiej rzeczywistości i upowszechnianie ${ }^{2}$.

W sferze społecznej ogromnym osiągnięciem tego okresu była Konstytucja Japonii, na mocy której rozwijano i publikowano akty niższego rzędu. Jednym z kluczowych zadań było podniesienie wykształcenia ówczesnego społeczeństwa japońskiego i kreowanie nowych elit. Nową drogą osiągania wysokich pozycji społecznych - obok dotychczasowej i związanej z urodzeniem w rodzinie cesarskiej, samurajskiej lub arystokratycznej - było osiągnięcie wykształcenia wyższego. W okresie Meiji powstają zatem uniwersytety cesarskie oraz szkoły wyższe kształcące nauczycieli. Następnie wyłaniają się uniwersytety prywatne ${ }^{3}$.

2 J. Splisgart, Przemiany ery Meiji (1868-1912). Modernizacja a formowanie się „nowej” tożsamości Japonii, „Gdańskie Studia Azji Wschodniej” 2016, nr 10, s. 41-57.

3 B.C. Duke, The history of modern Japanese education: constructing the national school system, 1872-1890, New Brunswick-New Jersey-London 2009, s. 51-54. 
Jednym z rozwijanych kierunków studiowania jest wówczas także psychologia. Jednak zanim studenci mogli wysłuchać w salach wykładowych uniwersytetów wykładów z psychologii, zaszła w Japonii ewolucyjna zmiana. Przednowoczesne nauczanie wybranych aspektów psychologii miało miejsce w anglojęzycznej szkole Doshisha English Academy w Kioto. Cykl wykładów z filozofii mentalnej prowadził tam Joseph Hardy Neesimy (1843-1890). W latach 1875-1884 jego uczniem był Yūjirō Motora (1858-1912), który po ukończeniu studiów z filozofii i psychologii na Uniwersytecie w Bostonie oraz na Uniwersytecie Johna Hopkinsa w Baltimore w Stanach Zjednoczonych stał się pionierem psychologii japońskiej ${ }^{4}$.

W 1888 r. Yūjirō Motora, po przedstawieniu dysertacji doktorskiej przygotowanej pod kierunkiem Granville'a Stanleya Halla na Uniwersytecie Johna Hopkinsa, uzyskał tytuł doktora filozofii, następnie zapoczątkował wykłady z psychofizyki (seishin batsurigaku) na Cesarskim Uniwersytecie w Tokio. Dwa lata później objął stanowisko profesora tejże uczelni. W 1903 r. Motora założył pierwsze w Japonii laboratorium psychologiczne. Rok później stanął na czele nowo powołanej katedry psychologii i uruchomił pierwszy dwuletni program studiów zakresie psychologii (Shinrigaku). W 1905 r. pięciu absolwentów tego kierunku opuściło mury uczelni. Motora prowadził badania naukowe, publikował artykuły (część w języku angielskim i niemieckim), tłumaczył prace G. Stanleya Halla oraz Wilhelma Wundta na język japoński. Jego wystąpienie pt. Idea filozofii ego w filozofii orientalnej, wygłoszone podczas V Międzynarodowego Kongresu Psychologicznego w Rzymie, spotkało się z dużym zainteresowaniem, a treść referatu ukazała się w druku. Po śmierci Motory (w 1912 r.), w 1915 r. opublikowana została jego

4 B.J. McVeigh, The History of Japanese Psychology. Global Perspectives (1875-1950), Bloomsbury-London 2018, s. 1-2. 


\section{monografia naukowa pt. Shinrigaku gairon, pierwsza psycholo- giczna praca zwarta napisana w języku japońskim ${ }^{5}$.}

\section{Tabela 1. Chronologia najważniejszych faktów w okresie wyłaniania się psychologii w Japonii.}

\begin{tabular}{|c|c|}
\hline Rok & Najważniejsze fakty \\
\hline $1867-1868$ & Zapoczątkowanie zmiany społecznej w ramach restauracji Meiji \\
\hline 1873 & Nauczanie filozofii mentalnej w Doshisha English Academy w Kioto \\
\hline 1875 & $\begin{array}{l}\text { Publikacja pierwszej książki z zakresu problematyki psychologicznej Josepha Haive- } \\
\text { na pt. Mental Philosophy, w przekładzie Nishi Amane. Tytuł japoński - Shinrigaku }\end{array}$ \\
\hline 1877 & $\begin{array}{l}\text { Nauczanie elementów psychologii na Uniwersytecie Tokijskim oraz Wyższej Szkole } \\
\text { Nauczycielskiej w Tokio }\end{array}$ \\
\hline 1888 & $\begin{array}{l}\text { Yūjirō Motora (1858-1912) zapoczątkowuje wykłady z psychofizyki na Cesarskim } \\
\text { Uniwersytecie w Tokio }\end{array}$ \\
\hline 1890 & Yūjirō Motora obejmuje stanowisko profesora Cesarskiego Uniwersytetu w Tokio \\
\hline 1900 & $\begin{array}{l}\text { Tomeri Tanimoto (1867-1946) i Tongo Takebe }(1871-1945) \text { prezentują swoje refe- } \\
\text { raty na IV Międzynarodowym Kongresie Psychologicznym w Paryżu }\end{array}$ \\
\hline 1903 & Yūjirō Motora zakłada pierwsze w kraju laboratorium psychologiczne \\
\hline 1904 & $\begin{array}{l}\text { Na Wydziale Literatury Cesarskiego Uniwersytetu w Tokio powstaje pierwsza kate- } \\
\text { dra Psychologii - kierowana przez Yūjirō Motorę }\end{array}$ \\
\hline 1904 & $\begin{array}{l}\text { Yũjirō Motora otwiera na Cesarskim Uniwersytecie w Tokio dwuletnie studia na } \\
\text { kierunku psychologia }\end{array}$ \\
\hline 1905 & $\begin{array}{l}\text { Pięciu absolwentów kończy studia z zakresu psychologii w Katedrze Psychologii } \\
\text { Cesarskiego Uniwersytetu w Tokio }\end{array}$ \\
\hline 1905 & $\begin{array}{l}\text { Yūjirō Motora wygłasza referat pt. Idea ego w filozofii orientalnej podczas V Między- } \\
\text { narodowego Kongresu Psychologicznego w Rzymie }\end{array}$ \\
\hline 1906 & $\begin{array}{l}\text { Matatarō Matsumoto (1865-1943) obejmuje stanowisko profesora Cesarskiego } \\
\text { Uniwersytetu w Kioto }\end{array}$ \\
\hline 1912 & Zapoczątkowanie publikacji czasopisma „Shinri Kenkyu” („Psychological Research”) \\
\hline 1915 & $\begin{array}{l}\text { Publikacja pierwszej monografii z zakresu psychologii, autorstwa Yūjirō Motora pt. } \\
\text { Shinrigaku gairon }\end{array}$ \\
\hline 1926 & $\begin{array}{l}\text { Zapoczątkowanie publikacji czasopisma „Shinrigaku Kenkyu” („Japanese Journal } \\
\text { of Psychology”) }\end{array}$ \\
\hline 1927 & $\begin{array}{l}\text { Powstanie Japońskiego Towarzystwa Psychologicznego (Japanese Psychological } \\
\text { Association) }\end{array}$ \\
\hline 1931 & $\begin{array}{l}\text { Powstanie Japońskiego Towarzystwa Psychologii Stosowanej (Japanese Association } \\
\text { of Applied Psychology) }\end{array}$ \\
\hline $1937-1941$ & $\begin{array}{l}\text { Przed przystąpieniem Japonii do wojny działa w Japonii } 15 \text { laboratoriów psycholo- } \\
\text { gicznych na } 15 \text { uniwersytetach prowadzących kształcenie w zakresie psychologii (na } \\
6 \text { uniwersytetach cesarskich, } 2 \text { państwowych i } 7 \text { prywatnych) }\end{array}$ \\
\hline 1945 & $\begin{array}{l}\text { Kapitulacja Japonii, zapoczątkowanie okupacji amerykańskiej, eksperci amerykańscy } \\
\text { zapoczątkowują wraz z psychologami japońskimi nową wizję rozwoju w demokra- } \\
\text { tycznym społeczeństwie, w nowym porządku prawnym i politycznym }\end{array}$ \\
\hline 1952 & Koniec okupacji amerykańskiej. Wyłanianie się subdyscyplin psychologii \\
\hline
\end{tabular}

Źródło: T. Sato, The history of psychology in Japan, „Japanese Psychological Review" 2005, t. 47, nr 2, s. 48; M. Takasuna, Japanese Participants at

5 T. Sato, The history of psychology in Japan, „Japanese Psychological Review" 2005, t. 47, nr 2, s. 47. 
International Congress of Psychology Pre-IIWW, „Japanese Psychological Research" 2016, t. 58, nr S1, s. 129-137.

Kontynuatorami życiowej misji Motory są jego studenci. Jednym z najbardziej znanych był Matatarō Matsumoto, absolwent Cesarskiego Uniwersytetu w Tokio, Uniwersytetu Lipskiego w Niemczech oraz Uniwersytetu Yale w Stanach Zjednoczonych, gdzie w 1899 r. uzyskał tytuł doktora. W 1906 r. objął stanowisko profesora Cesarskiego Uniwersytetu w Kioto. Największym osiągnięciem Matsumoto było wprowadzenie w japońskich laboratoriach psychologicznych metod i technik doświadczalnych opracowanych w Niemczech i Stanach Zjednoczonych. W 1913 r. przeniósł się na Cesarski Uniwersytet w Tokio, gdzie objął Katedrę Psychologii po zmarłym profesorze Yūjirō Motora. Matsumoto prowadził intensywną działalność naukową i organizacyjną do 1926 r., kiedy przeszedł na emeryturę. Był współzałożycielem kilku czasopism naukowych w dziedzinie psychologii oraz Japońskiego Towarzystwa Psychologicznego ${ }^{6}$.

Warto w tym miejscu poczynić uwagę, że psychologia japońska była - obok psychologii chińskiej - najdynamiczniej rozwijającą się dziedziną nauki oraz kierunkiem studiów wśród krajów niezachodnich na przełomie XIX i XX w. ${ }^{7}$ Psycholodzy japońscy prowadzili systematyczne badania naukowe, wygłaszali referaty na kongresach, publikowali artykuły w czasopismach naukowych krajowych i zagranicznych oraz monografie, rozwijali metodologię badań, stowarzyszali się w towarzystwach naukowych. Rozwój nowoczesnej psychologii w Japonii zachodzi w wyniku zetknięcia się zachodniej idei

6 Idem, Rises and Falls of Clinical Psychology in Japan: a Perspective on the Status of Japanese Clinical Psychology, „Ritsumeikan Journal of Human Sciences" 2007, nr 13, s. 2.

7 Idem, The history..., op.cit., s. 47. 
z specyfiką kultury i społeczeństwa japońskiego, co doprowadziło do powstania unikalnej idei w sferze badań naukowych i kreowania teorii naukowej oraz konstrukcji i charakteru działań na poziomie praktyki ${ }^{8}$.

Ten intensywny rozwój przerywa narastający na początku XX w. nacjonalizm i militaryzm, a zwłaszcza angażowanie się Japonii w wojny (I wojna chińsko-japońska, wojna rosyjsko-japońska, I wojna światowa, II wojna chińsko-japońska, II wojna światowa). Kolejną fazę rozwojową psychologii datuje się po drugiej wojnie światowej, od 1952 r., wraz zakończeniem okupacji amerykańskiej (por. - tabela 1). Fazę powojenną charakteryzuje wyłanianie się i rozwój subdyscyplin psychologii, a wśród nich także psychologii szkolnej.

\section{Inicjatywy prowadzące do rozwoju teorii i praktyki psychologii szkolnej}

Wyłonienie się psychologii szkolnej (początkowo było to szersze pole psychologii wychowania) wiązało się z rozwojem kształcenia w szkołach wyższych przygotowujących nauczycieli w Japonii. Część spośród znanych psychologów wykładało w nich psychologię już w latach 80. XIX w. i na początku XX w. Działalność dydaktyczna wymagała też zapewnienia podręczników. Dlatego w tym wczesnym okresie publikowane były głównie przekłady podręczników amerykańskich i zachodnioeuropejskich. Motora - pozostający pod wpływem swojego promotora pracy doktorskiej, Granville’a Stanleya Halla - prowadził po przyjeździe do Japonii badania empiryczne nad dziecięcymi praktykami asocjacji wyrazów, a nieco później zainteresował się znaczeniem

8 H. Azuma, H. Imada, Origins and development of psychology in Japan: the interaction between Western science and the Japanese cultural heritage, „International Journal of Psychology” 1994, nr 29, s. 707-715. 
moralności w okresie adolescencji. Badał również u dzieci odczytywanie japońskich ideogramów z zastosowaniem hiragany i katakany, rozważając przy tym możliwości wpływu stosowania różnych pomocy dydaktycznych - w toku eksperymentów - na utrzymywanie uwagi przez uczniów podczas lekcji. Motora był założycielem (w 1900 r.) i pierwszym przewodniczącycm Towarzystwa Badań nad Dzieckiem, w którego działalność bardzo zaangażował się zarówno na rzecz rozwoju teorii psychologii wychowania, jak i przenoszenia jej do praktyki edukacyjnej. W 1911 r. opublikował artykuł pt. Ein Experiment zur Einübung von Aufmerksamkeit (Eksperyment nad ćwiczeniem uwagi) w 16 czasopisma naukowego "Zeitschrift für Kinderforschung”. Była to pierwsza publikacja japońskiego psychologa z zakresu psychologii klinicznej. Z kolei Matsumoto po powrocie do Japonii w 1900 r. wykładał psychologię eksperymentalną w wyższej szkole kształcącej nauczycieli9.

Po zakończeniu II wojny światowej eksperci amerykańscy ${ }^{10}$, wchodzący w skład Pierwszej i Drugiej Amerykańskiej Misji

9 T. Sato, The History of Applied Psychology in Japan, https://www. ritsumeihuman.com/uploads/publications/97/9_76.pdf, s. 80-81 [dostęp: 14.12.2019].

10 Współpraca amerykańsko-japońska została zapoczatkowana w marcu 1946 r. Grupą specjalistów amerykańskich kierował Alexander J. Stoddard (emerytowany rektor Uniwersytetu Illinois). Wśród 27 znalezli się: Wilson Compton (rektor Uniwersytetu Chicago) oraz Ernest R. Hilgard (dziekan Wydziału Psychologii na Uniwersytecie Stanforda). Członkowie delegacji amerykańskiej dokonali przeglądu powojennej sytuacji instytucji edukacyjnych w Japonii oraz podjęli dyskusję i współpracę z partnerami japońskimi, m.in. z Shigeru Nambara (rektorem Cesarskiego Uniwersytetu w Tokio), Teiyu Amano (dyrektorem I Wyższej Szkoły Średniej w Tokio) oraz Mantaro Kido (dyrektorem Instytutu Szkolenia Nauczycieli w Tokio). Zespół amerykański opracował i opublikował raport (Report of the first United States education mission to Japan). W oparciu o wnioski i zalecenia raportu zapoczątkowano reformę systemu edukacji w powojennej Japonii. Druga delegacja amerykańskich ekspertów zapoczątkowała pod koniec 1950 r. czynności sprawdzające postępy reformy i przygotowała raport końcowy. Por. K. Tsuji, Development of educational Psychology in Japan, „Japanese Psychological Research" 2016, t. 59, nr 1, s. 46. 
Edukacyjnej, współpracując z nowym, demokratycznym rządem japońskim, zapoczątkowali formowanie nowego kształtu rzeczywistości edukacyjnej i naukowej ${ }^{11}$. W dziedzinie psychologii przyniosło to ogromne, trwające ponad dekadę ożywienie akademickiego kształcenia, określenie nowych kierunków badań naukowych oraz zrzeszania się wokół subdyscyplin i stosowanych dziedzin psychologii w ramach towarzystw. I tak w okresie tym powstały następujące organizacje:

- 1949 r. - Japońskie Towarzystwo Dynamiki Grupowej (Japanese Group Dynamics Association);

- 1952 r. - Japońskie Towarzystwo Psychologii Wychowania (Japanese Educational Psychology Association);

- 1960 r. - Japońskie Towarzystwo Psychologii Społecznej (Japanese Social Psychology Association);

- 1963 r. - Japońskie Towarzystwo Psychologii Kryminalistycznej (Japanese Criminal Psychology Association) oraz Japońskie Towarzystwo Edukacji dla Niepełnosprawnych (Association of Education for the Handicapped) ${ }^{12}$.

Psychologia wychowania staje się przestrzenią integrującą działalność pedagogów i psychologów. Zwiększa się znacząco liczba tych grup absolwentów studiów uniwersyteckich, oraz następuje powolna ich profesjonalizacja. Psycholodzy kliniczni i psycholodzy wychowania adaptują do warunków społeczeństwa japońskiego testy psychologiczne - np. Skalę Inteligencji Wechslera (WAIS), Test Osobowości (MMPI) ${ }^{13}$.

Lata 60. i 70. XX w. to okres podporządkowania psychologii dynamicznie zachodzącej industrializacji. Zarówno psycholo-

11 Szerzej na temat przemian edukacji podczas okupacji amerykańskiej 1946-1952 piszę w: M. Cylkowska-Nowak, Społeczne funkcje szkolnictwa w Japonii i Stanach Zjednoczonych. Studium z pedagogiki porównawczej, , Poznań-Toruń 2000, s. 72-74.

12 T. Sato, The History of Applied Psychology in Japan..., op.cit., s. 85.

13 Ibidem. 
gia, jak i pedagogika mają wspierać populację japońską w przygotowaniu się do udziału w podziale pracy oraz perfekcyjnym wypełnianiu powierzonych ról. Dotyczyło to w równym stopniu szkół, klas szkolnych, jak i miejsc pracy. W kolejnych latach ujawniły się nieprzewidziane efekty rozwoju gospodarczego, społecznego oraz towarzyszących im reform edukacyjnych, takie jak: „egzaminacyjne piekło” (juken jigoku), grupowa forma agresji rówieśniczej (ijime), fobia szkolna (tōkōkyohi), długotrwała absencja uczniów o liczbie większej niż 30 dni opuszczonych w ciągu roku szkolnego (futōkō) oraz syndrom skrajnego wycofania społecznego (hikikomori) ${ }^{14}$. Istniejące wówczas formy wsparcia uczniów i rodziców nie zaspokajały narastających potrzeb. Wzrasta niezadowolenie wokół społecznych funkcji edukacji w Japonii ${ }^{15}$.

Na przełomie lat 1988 i 1989 ukazuje się w Japonii 13-tomowy Kurs psychologii stosowanej (Course on applied psychology) pod redakcją Jyuji Misumi i współredaktorów (T. Konoshita, S. Akita, T. Takizawa, Y. Nagayama, N. Itoigawa), a w nim opisy teorii i badań w zakresie psychologii wychowania, psychologii klinicznej, psychologii zdrowia ${ }^{16}$.

W 1990 r. Japońskie Towarzystwo Psychologii Wychowania (Japanese Association of Educational Psychology) powołało Komitet Wykonawczy Psychologii Szkolnej. Inicjatywa ta wyłoniła się pod wpływem ogromnej społecznej presji rodziców dzieci i młodzieży w wieku szkolnym oraz stowarzyszeń działających na rzecz zmian w systemie szkolnym. Środowiska

14 Szerzej zjawiska te charakteryzuje w: M. Cylkowska-Nowak, Ijime, hikikomori $i$ edukacja alternatywna w Japonii, [w:] Edukacja alternatywna w XXI wieku, red. Z. Melosik, B. Śliwerski, Kraków 2010, s. 175-195.

15 T. Kariya, J.E. Rosenbaum, Bright Flight: unintended consequences of detracking policy in Japan, „American Journal of Education” 1999, nr 107, s. 223-225.

16 J. Misumi, T. Konoshita, S. Akita, T. Takizawa, Y. Nagayama, N. Itoigawa (red.), Course of applied psychology, Tokyo 1989. 
te głosiły pogląd, że „psychologia wychowania nie jest użyteczna dla edukacji” w dotychczasowej formie działalności. Powszechnie promowane było przekonanie, że wprowadzenie psychologii szkolnej zamiast psychologii wychowania uczyni działania pedagogów i psychologów bardziej praktycznymi i przynoszącymi oczekiwane efekty.

W 1995 r. rząd japoński zapoczątkowuje zatrudnianie w szkołach doradców szkolnych w ramach projektu badawczego, który ma pomóc przeciwdziałać nieuczęszczaniu uczniów do szkoły oraz ijime. W tym samym roku rozpoczęto certyfikację psychologów klinicznych.

W 1996 r. Japońskie Towarzystwo Psychologii Wychowania zorganizowało sympozjum z zakresu psychologii szkolnej. Toshinori Ishikuma ${ }^{17}$ zaprezentował wystąpienie na temat $P$ sychologia szkolna w Stanach Zjednoczonych i Japonii, w którym zawarł koncepcję usług psychoedukacyjnych. Z kolei w $1997 \mathrm{r}$. Japońskie Towarzystwo Psychologii Wychowania zapoczątkowało certyfikację psychologów szkolnych. W tym samym roku powstało Japońskie Towarzystwo Psychologii Szkolnej ${ }^{18}$.

W 2001 r. ukazał się pierwszy numer "Japanese Journal of School Psychology". W 2004 r. opublikowano Act on Support for Persons with Developmental Disabilities. W 2009 r. zapoczątkowano wydawanie czasopisma naukowego "Annual Review of Japanese Association of School Psychologists"19.

Psychologia szkolna została zdefiniowana w Japonii jako „pole integrowania edukacji i psychologii, w którym praktyki

17 T. Ishikuma, School psychology: psycho-educational services by a team of teachers, school counselor, and parents, Tōkyō 1999.

18 H. Mizuno, T. Ishikuma, Help-Seeking Preferences and Help-Seeking Behaviors: An Overview of Studies, „Japanese Journal of Educational Psychology" 1999, nr 47, s. 530-539.

19 T. Ishikuma, Y. Shinohara, T. Nakao, School psychology in Japan, [w:] The Handbook of International School Psychology, red. S.R. Jimerson, T.D. Oakland, P.T. Farrell, Thousand Oaks-London-New Dehli 2007, s. 217-227. 
i badania dotyczące usług psychoedukacyjnych dla uczniów są dyskutowane i scalane w celu dostarczenia każdemu uczniowi pomocy w radzeniu sobie z problemami psychospołecznymi, zdrowotnymi, związanymi z nauką oraz rozwojem kariery" ${ }^{20}$.

Certyfikację przeprowadzało Japońskie Towarzystwo Psychologów Szkolnych w ramach zadań 31 regionalnych oddziałów. Zadanie to było koordynowane przez Japanese Organization of Certifying and Managing School Psychologists. Z uwagi na zróżnicowane wykształcenie aplikantów wyłoniono pięć typów certyfikacji:

- typ A - magistrzy, ze zdanymi w toku studiów siedmioma przedmiotami psychologicznymi, jeden rok doświadczenia w świadczeniu porad psychopedagogicznych;

- typ B - nauczyciele, nauczyciele pedagogiki specjalnej, nauczyciele zdrowia, pięcioletni staż $\mathrm{w}$ świadczeniu porad psychopedagogicznych;

- typ C - specjaliści poradnictwa: magistrzy, ze zdanymi czterema z siedmiu przedmiotów psychologicznych oraz dwa lata stażu w świadczeniu usług psychopedagogicznych, albo magistrzy po studiach niezwiązanych z psychologią lub z wykształceniem przeddyplomowym oraz pięć lat stażu w świadczeniu porad psychopedagogicznych;

- typ D - profesorowie uniwersytetów lub wyższych szkół zawodowych nauczający przedmiotów związanych z psychologią szkolną, a także prowadzący w tej dziedzinie badania naukowe;

- typ E - wszyscy certyfikowani lub licencjonowani w tej dziedzinie (także obcokrajowcy).

Wszyscy aplikanci odbywają egzamin certyfikacyjny, przy czym aplikanci z kwalifikacjami typu B i C piszą egzamin te-

20 H. Mizuno, T. Ishikuma, Help-Seeking Preferences and Help-Seeking Behaviors: an Overview of Studies, "Japanese Journal of Educational Psychology" 1999, nr 47, s. 531. 
stowy z pytaniami wielokrotnego wyboru z sześciu przedmiotów związanych z psychologią szkolną. Pozostali odbywają egzamin w formie eseju. Natomiast wszyscy przygotowują i oddają pod ocenę raport $\mathrm{z}$ nadzorowanego studium przypadku ${ }^{21}$. W 2018 r. przeprowadzono 4 tys. certyfikacji.

Psycholodzy szkolni kształcą się w Japonii w ramach czteroletnich studiów przeddyplomowych, prowadzonych w 33 szkołach wyższych (w tym w 24 państwowych). Aby studia spełniały wymogi późniejszej certyfikacji, muszą uwzględniać w programie studiów następujące przedmioty:

- psychologia: psychologia szkolna, psychologia rozwojowa, psychologia kliniczna;

- pedagogika szkolna: wspieranie rozwoju ucznia i doradztwo w karierze, pedagogika i psychologia uczniów z niepełnosprawnościami;

- umiejętności świadczenia porad psychoedukacyjnych: ewaluacja i stosowanie testów psychologicznych, poradnictwo szkolne i konsultacje.

Czynnikiem mającym w Japonii ogromny wpływ na zmiany w sferze psychologii szkolnej są też sytuacje kryzysowe, takie jak: trzęsienia ziemi, tsunami, erupcje wulkanów. Po trzęsieniu ziemi w Tōhoku w 2011 r. i ogromnych skutkach tej katastrofy nastąpiła konsolidacja działań psychologów szkolnych skupionych w Japońskim Towarzystwie Psychologii Szkolnej z psychologami działającymi w ramach Japońskiego Towarzystwa Psychologów Klinicznych. Obie organizacje współpracowały bardzo ścisłe z rządem japońskim w niesieniu pomocy dzieciom, młodzieży, osobom dorosłym, będącym w sytuacji kryzysowej. Ponadto w działanie te włączyły się także organizacje

21 T. Ishikuma, Y. Shinohara, T. Nakao, School psychology in Japan, [w:] The Handbook of International School Psychology, red. S.R. Jimerson, T.D. Oakland, P. . Farrell, Thousand Oaks-London-New Dehli 2007, s. 217$-227$. 
międzynarodowe - International School Psychology Association (ISPA) oraz amerykańskie National Association of School Psychologists (NASP).

W 2015 r. dzięki współpracy różnych grup psychologów oraz badaczy przygotowane zostały i opublikowane nowe regulacje prawne dotyczące praktyki psychologii szkolnej oraz certyfikacji aplikantów. W dokumencie tym dookreślono formalnie profesjonalne role certyfikowanych psychologów szkolnych. Obecnie są to:

- ocenianie - planowanie ocen, scalanie informacji, administrowanie testami psychologicznymi, przeprowadzanie badań i interpretacja ich wyników;

- poradnictwo i interwencja - prowadzone indywidualnie i grupowo oraz udzielanie wsparcia długotrwałego; doraźne treningi umiejętności;

- konsultacja i działania w dziedzinie koordynacji współpracy z personelem szkolnym, rodzicami, innymi profesjonalistami, np. lekarzami psychiatrami, neurologami, terapeutami zajęciowymi, fizjoterapeutami, psychoterapeutami i innymi;

- edukacja na rzecz zdrowia psychicznego - dostarczanie wiedzy psychologicznej oraz rozwijanie umiejętności pozwalających zachować zdrowie psychiczne w toku pokonywania kolejnych etapów edukacji szkolnej.

Doprecyzowanie ról pozwoliło w praktyce psychologii szkolnej na bardziej precyzyjne dookreślenie kierunków działalności w japońskiej szkole. W tym kontekście najczęściej wymienia się:

- dziecko jako jednostka, jego życie szkolne, potencjalne lub rzeczywiste problemy zdrowia psychicznego;

- środowiska, np. kultura i funkcja klasy szkolnej oraz szkoły;

- wzajemne relacje pomiędzy dziećmi a środowiskiem, np. dopasowanie stylów nauczania i uczenia się, stopień 
dostrojenia stylu zachowania dziecka do oczekiwanego zachowania.

Grupa osób zajmująca się psychologią szkolną w Japonii jest aktualnie zróżnicowana. Wynika to z obecności w szkołach osób o różnych kwalifikacjach i podejmujących różne zadania. Ponadto wynika to też ze zmian prawnych, które regulowały historycznie kwalifikacje. Można wskazać tu następujące grupy:

- wszyscy nauczyciele, w tym zwłaszcza nauczyciele przedmiotów szkolnych, wychowawcy klas, nauczyciele podejmujący role psychoedukacyjne, inni profesjonaliści zatrudnieni w szkole, doradcy szkolni, czyli osoby pozostające w relacji z uczniami i ich rodzicami na co dzień i wspierający w rozwiązywaniu różnych trudności oraz pokonywaniu zadań rozwojowych przez dzieci;

- nauczyciele prowadzący szkolenia i treningi, a zwłaszcza szkolący w zakresie orientacji życiowej i zawodowej, psychologii rozwojowej, psychologii wychowawczej, doradzający i ukierunkowujący uczniów (i w pewnych okolicznościach także nauczycieli i rodziców);

- nauczyciele zatrudnieni na stanowiskach doradczych, pracujący w szkolnych działach poradnictwa, w działach poradnictwa zawodowego;

- inni nauczyciele: edukacji specjalnej, wspierającej, inkluzyjnej, zdrowotnej, pracujący na rzecz podnoszenia poziomu zdrowia fizycznego i psychicznego dzieci oraz młodzieży.

Od tych dwóch grup wymagane jest odnowienie certyfikacji po dziesięciu latach z uwagi na konieczność aktualizacji wiedzy i umiejętności oraz dostosowanie się do zmieniających się oczekiwań społecznych rodziców.

- doradcy szkolni, głównie psycholodzy, często pracujący w niepełnym wymiarze czasu pracy (4-8 godzin tygo- 
dniowo) w kilku szkołach, posiadający certyfikację psychologa klinicznego wydaną przez Fundację Japońskiej Rady Certyfikacyjnej Psychologa Klinicznego (Foundation of the Japanese Certification Board for Clinical Psychologist), podejmują głównie zadania związane z ocenianiem oraz prowadzeniem terapii.

Warto w tym miejscu podkreślić, że psycholog szkolny i psycholog kliniczny to certyfikacja umożliwiająca podejmowanie ściśle określonych zadań zawodowych, a nie zawód sam w sobie. Większość certyfikacji jest wydawanych na określony czas, po którym istnieje konieczność podjęcia szkoleń, superwizji oraz uzupełnienia kwalifikacji.

Aktualnie oddziaływania psychologii szkolnej praktykowane są w Japonii na trzech poziomach:

- pierwszym - odnoszącym się do powszechnych i podstawowych potrzeb dzieci w klasie lub w szkole, uniwersalnych projektów lekcji, zapewnienia bezpieczeństwa i wspierającej edukacji w klasie szkolnej oraz związanym z rozwojem kariery uczniów;

- drugim - dodanym do poziomu pierwszego i koncentrującym się na odpowiedzi na dodatkowe lub specjalne potrzeby niektórych dzieci z grup ryzyka, np. opóźnienie $\mathrm{w}$ nauce, trudności w relacjach $\mathrm{z}$ innymi uczniami, brak promocji do kolejnej klasy, zagrożeniem porzuceniem edukacji szkolnej;

- trzecim - dodanym do poziomu pierwszego i drugiego i skupiającym się na odpowiedzi na specjalne potrzeby niektórych dzieci, np. w byciu ofiarą przemocy szkolnej lub rodzinnej, w doznawaniu trudności w uczeniu się, w przejawianiu zaburzeń nastroju, w byciu apatycznym i innych.

W praktyce szkolnej tworzone są struktury organizacyjne psychologii szkolnej mające na celu niesienie wsparcia. 
Najbliżej ucznia działa zespół zajmujący się jego problemami. W skład zespołu wchodzą: wychowawca lub nauczyciele w klasie, rodzice, nauczyciel zdrowia, koordynator oraz inni zapraszani z uwagi na rodzaj problemu dziecka (psycholodzy szkolni, psycholodzy kliniczni, doradcy, doradcy zawodowi).

Zespół pracujący bezpośrednio z uczniem może odwoływać się do doraźnie zwoływanych spotkań komitetu koordynacyjnego. Pracują w nim nauczyciele, nauczyciele zdrowia, administratorzy. Spotkania komitetu koordynacyjnego pozwalają omówić bieżące sprawy i dostosować rodzaj wsparcia do problemu ucznia.

Nad wszystkimi zespołami usytuowany jest zespół zarządzający, w skład którego wchodzi dyrektor szkoły, wicedyrektorzy, dyrektorzy oddziałów (jeśli takie zostały wyłonione w strukturze). Spotkania zespołu odbywają się regularnie w celu podejmowania kluczowych w systemie wsparcia decyzji.

\section{Zakończenie}

Zapotrzebowanie na systemy wsparcia konstruowane i prowadzone w ramach praktyki psychologii szkolnej we współczesnej Japonii nie maleje. Szkoła japońska zmaga się nadal ze zjawiskiem wagarowania, porzucania edukacji, przemocy, przestępczości młodzieży. Systematycznie rośnie zapotrzebowanie na profesjonalne wsparcie uczniów z trudnościami w uczeniu się, z zaburzeniami koncentracji uwagi, nadruchliwości, dla wysoko funkcjonujących dzieci z zaburzeniami ze spektrum autyzmu, dla dzieci i młodzieży z różnymi niepełnsoprawnościami. Zachodzące aktualnie przemiany rodziny japońskiej (rosnący wskaźnik rozwodów, zwiększająca się liczba rodzin niepełnych, zwłaszcza kobiet samodzielnie wychowujących dzieci) generują wiele nowych problemów populacji dzieci i młodzieży, które są „wnoszone" przez nie środowiska szkolnego. Bardzo znamien- 
nym jest nasilająca się apatia części uczniów, zwiększający się odsetek uczniów z zaburzeniami nastroju oraz z tendencjami do autoagresji ${ }^{22}$. Należy zatem przypuszczać, że najbliższe dekady będą okresem dalszego, bardzo intensywnego rozwoju psychologii szkolnej w Japonii, prowadzenia badań w tej dziedzinie i wyznaczania kierunków dla praktyki.

\section{Bibliografia}

Azuma H., Imada H., Origins and development of psychology in Japan: The interaction between Western science and the Japanese cultural heritage, "International Journal of Psychology" 1994, nr 29.

Cylkowska-Nowak M., Bullying $w$ edukacji w badaniach porównawczych, [w:] Instytucje edukacyjne - zagrożenia bezpieczeństwo. Konteksty prawne, społeczne, edukacyjne i zdrowotne, red. B. Wiśniewska-Paź, Toruń 2018.

Cylkowska-Nowak M., Ijime, hikikomori i edukacja alternatywna w Japonii, [w:] Edukacja alternatywna w XXI wieku, red. Z. Melosik, B. Śliwerski, Kraków 2010.

Cylkowska-Nowak M., Społeczne funkcje szkolnictwa w Japonii i Stanach Zjednoczonych. Studium z pedagogiki porównawczej, Poznań-Toruń 2000.

Duke B.C., The history of modern Japanese education: constructing the national school system, 1872-1890, New Brunswick-New Jersey-London 2009.

Ishikuma T., Matsuda O., Fujita K., Ueno K., Intellectual assessment of children and youth in Japan: Past, present, and future, "International Journal of School \& Educational Psychology" 2016, t. 4, nr 4.

22 K. Kumagai, Retnking the Role of the Psychologist in Japan: comparison with school Psychologists Work in Other Countries, „The Annual Report of Educational Psychology in Japan” 2008, t. 4, s. 223-230. 
Ishikuma T., Shinohara Y., Nakao T., School psychology in Japan, [w:] The Handbook of International School Psycholo$g y$, red. S.R. Jimerson, T.D. Oakland, P.T. Farrell, Thousand Oaks-London-New Dehli 2007.

Jimerson S.R., Oakland T.D., Farrell P.T., Introduction to The Handbook of International School Psychology, [w:] The Handbook of International School Psychology, red. S.R. Jimerson, T.D. Oakland, P.T. Farrell, Thousand Oaks-London-New Dehli 2007.

Kariya T., Rosenbaum J.E., Bright Flight: unintended consequences of detracking policy in Japan, "American Journal of Education" 1999, nr 107.

Kumagai K., Retnking the Role of the Psychologist in Japan: comparison with school Psychologists Work in Other Countries, „The Annual Report of Educational Psychology in Japan" 2008, t. 4.

McVeigh B.J., The History of Japanese Psychology. Global Perspectives (1875-1950), London 2018.

Misumi J., Konoshita T., Akita S., Takizawa T., Nagayama Y., Itoigawa N. (red.), Course of applied psychology, Tokyo 1989.

Misumi J., Konoshita T., Akita S., Takizawa T., Nagayama Y., Itoigawa N., Course of applied psychology, Tokyo 1989.

Mizuno H., Ishikuma T., Help-Seeking Preferences and Help-Seeking Behaviors: An Overview of Studies, „Japanese Journal of Educational Psychology" 1999, nr 47.

Sato T., Rises and Falls of Clinical Psychology in Japan: A Perspective on the Status of Japanese Clinical Psychology, „Ritsumeikan Journal of Human Sciences" 2007, nr 13.

Sato T., The History of Applied Psychology in Japan, https://www. ritsumeihuman.com/uploads/publications/97/9_76.pdf.

Sato T., The history of psychology in Japan, „Japanese Psychological Review" 2005, t. 47, nr 2. 
Shinagawa F., Kodama M., Manita A., School psychology in Japan, [w:] International Perspectives on Psychology in Schools, red. P.A. Saigh, T. Oakland, Hillsdale 1989.

Splisgart J., Przemiany ery Meiji (1868-1912). Modernizacja a formowanie się "nowej” tożsamości Japonii, „Gdańskie Studia Azji Wschodniej" 2016, z. 10.

Takasuna M., Japanese Participants at International Congress of Psychology Pre-IIWWW, „Japanese Psychological Research” 2016, t. 58, nr S1.

Tsuji K., Development of educational Psychology in Japan, „Japanese Psychological Research" 2016, t. 59, nr 1.

\section{Abstrakt}

Psychologia szkolna wyłoniła się w Japonii w latach 80. XX w. Ma ona integrować edukację i psychologię w ramach usług psychoedukacyjnych dla uczniów oraz dostarczać im pomoc w radzeniu sobie z problemami psychospołecznymi, zdrowotnymi, związanymi z nauką oraz rozwojem kariery.

Celem pracy jest ukazanie rozwoju psychologii i psychologii wychowania w Japonii oraz wyłonienia się w jej polu psychologii szkolnej.

Słowa kluczowe: psychologia szkolna, rozwój teorii i praktyki, Japonia

\section{Abstract}

School psychology emerged in Japan in the 1980s. It is to integrate education and psychology as part of psychoeducational services for students and provide them with help in dealing with psychosocial, health, science and career development problems.

The purpose of the article is to show the development of psychology and educational psychology in Japan and the emergence of school psychology in its field.

Keywords: school psychology, theory and practice development, Japan 


\section{Elżbieta Ceholnik-Szafran}

Uniwersytet Szczeciński

ORCID ID: https://orcid.org/0000-0002-0191-7393

\section{Podobieństwa i różnice między polskim a japońskim systemem edukacji}

\section{Wprowadzenie}

Analizie poddano systemy szkolnictwa w Polsce i Japonii biorąc pod uwagę organy zarządzające systemem edukacji, strukturę szkolnictwa, system egzaminacyjny, obowiązek szkolny oraz czas trwania roku szkolnego.

Autorka artykułu starała się odpowiedzieć na następujące pytanie badawcze:

1. Jakie są podobieństwa i różnice w systemie edukacji w Polsce i Japonii?

Udzielając odpowiedzi na powyższe pytanie wykorzystano metodę porównawczą i statystyczną. Metoda porównawcza pozwoliła zaprezentować różnice oraz podobieństwa pomiędzy systemami oświaty w Polsce i Japonii.

Z kolei metodę statystyczną wykorzystano do przedstawienia zainteresowania uczniów dalszym etapem edukacji.

Przedmiotem badań pedagogiki porównawczej jest między innymi struktura systemu edukacji w Polsce i Japonii. Jan Průcha przytacza w swojej pracy definicję pedagogiki porównawczej autorstwa Williama W. Brickmana, według którego „Pedagogika porównawcza to analiza systemów i problemów pedagogiki w dwóch lub kilku krajach, w kontekście ich historycznych, społeczno-ekonomicznych, politycznych, kultu- 
rowych, religijnych i innych znaczących uwarunkowań. Pedagogika porównawcza jest interdyscyplinarną dziedziną badań, czerpiącą z socjologii i ekonomii procesów kształcenia, z informacji o ich rozwoju historycznym i współczesnej polityce oświatowej" 1 .

Isaac Kandel uważał, że „porównanie systemów oświatowych w kilku krajach może być realizowane za pomocą różnych metod w zależności, do pewnego stopnia, od celów"2.

Pedagogika porównawcza służy porównaniu funkcjonowania i organizacji systemów oświaty w zestawionych ze sobą państwach.

Jan Szczepański uważał, że istnieją dwa znaczenia systemu oświaty. Pojęcie to węższym zakresie oznacza system szkolny, tzn. układ szkół od przedszkoli do studiów podyplomowych. W szerszym zakresie przez system oświaty „rozumie się całkowity układ wszystkich instytucji, grup organizacji i urządzeń, poprzez które wiedza naukowa, ideologia, system wartości, wzory osobowości (...) docierają do społeczeństwa. Przyjmując to drugie znaczenie zwrotu, mówimy czasami o - całkowitym systemie oświaty - podkreślając, że chodzi o całość oddziaływań, kształtujących postawy, wartości, przekonania, zachowania - słowem, kształtujących osobowości, działania i postępowania obywateli"3.

\section{System szkolnictwa w Polsce}

System edukacji w Polsce obejmuje przedszkola (w tym specjalne), szkoły podstawowe i ponadpodstawowe, placówki

1 J. Průcha, Pedagogika porównawcza. Podstawy międzynarodowych badań oświatowych. Podręcznik akademicki, Warszawa 2004, s. 32.

2 R. Pachociński, Zarys pedagogiki porównawczej, Warszawa 1998, s. 5.

3 M. Pęcharski, Polityka oświatowa, Wrocław 1975, s. 34. 
oświatowo-wychowawcze, poradnie wychowawczo-zawodowe i psychologiczno-pedagogiczne, placówki opiekuńczo-wychowawcze i resocjalizacyjne, rodziny zastępcze, ośrodki adopcyjno-opiekuńcze, Ochotnicze Hufce Pracy, zakłady kształcenia i placówki doskonalenia nauczycieli.

W Polsce system oświaty regulowany jest przez Kartę Nauczyciela $^{4}$, prawo oświatowe ${ }^{5}$ oraz ustawy: o systemie oświaty ${ }^{6}$ i wprowadzającą reformę ustroju szkolnego ${ }^{7}$. Polsce rok szkolny zgodnie z prawem oświatowym i rozporządzeniem ministra Edukacji Narodowej rozpoczyna się we wrześniu i kończy w czerwcu.

W szkołach podstawowych i ponadpodstawowych zajęcia rozpoczynają się w pierwszym dniu września, a kończą w najbliższy piątek po dniu 20 czerwca. Jeżeli pierwszy dzień września wypada w piątek albo sobotę, zajęcia rozpoczynają się w najbliższy poniedziałek po dniu 1 wrześni ${ }^{8}$. Rozporządzenie Ministra Edukacji Narodowej z dnia 12 czerwca 2019 r. wprowadziło w $\$ 2$ w ust. 1 zdanie trzecie w brzmieniu: „Jeżeli czwartek bezpośrednio poprzedzający najbliższy piątek po dniu 20 czerwca jest dniem ustawowo wolnym od pracy, zajęcia dydaktyczno-wychowawcze kończą się w środę poprzedzającą ten dzień". Ferie zimowe trwają dwa tygodnie w okresie od połowy stycznia do końca lutego.

4 Ustawa z dnia 26 stycznia 1982 r. Karta Nauczyciela, Dz.U. 1982, nr 3, poz. 19 z późn. zm.

5 Ustawa z dnia 14 grudnia 2016 r. Prawo oświatowe, Dz.U. 2017, poz 59 z późn. zm.

6 Ustawa z dnia 7 września 1991 r. o systemie oświaty, Dz.U. 1991, nr 95, poz. 425 z późn. zm.

7 Ustawa z dnia 8 stycznia 1999 r. Przepisy wprowadzające reformę ustroju szkolnego, Dz.U. 1999, nr 12, poz. 96 z późn. zm.

8 Rozporządzenie Ministra Edukacji Narodowej z dnia 11 sierpnia 2017 r. w sprawie organizacji roku szkolnego Dz.U. 2017, poz. 1603. 
Ferie letnie rozpoczynają się w dniu następującym po dniu zakończenia rocznych zajęć dydaktyczno-wychowawczych i kończą się z dniem 31 sierpnia 9 .

W Polsce po 1989 r. zasadnicze zmiany w systemie edukacji wprowadzono w latach 1999 i 2017 . W 1999 r. reforma sytemu edukacji była wprowadzona przez rząd Jerzego Buzka z ministrem edukacji narodowej Mirosławem Handke.

Reforma systemu edukacji z 2017 r. była jednym z głównych celów rządu Prawa i Sprawiedliwości.

W latach 1989-1998 w Polsce struktura systemu oświaty była dwustopniowa i obejmowała: ośmioletnie szkoły podstawowe ${ }^{10}$ oraz szkoły ponadpodstawowe. Do kategorii szkół ponadpodstawowych należały trzyletnie zasadnicze szkoły zawodowe, czteroletnie licea ogólnokształcące i szkoły średnie zawodowe (między innymi czteroletnie licea techniczne i zawodowe, pięcioletnie technika zawodowe oraz szkoły policealne i pomaturalne).

Reforma systemu oświaty z 1999 r. zakładała zmianę struktury szkolnictwa z dwustopniowej na trzystopniową. Ośmioletnią szkołę podstawową skrócono do sześciu lat. Powstały trzyletnie gimnazja oraz szkoły ponadgimnazjalne czyli dwulub trzyletnie zasadnicze szkoły zawodowe, trzyletnie licea ogólnokształcące, trzyletnie licea profilowane, czteroletnie technika. 1 września 2017 r. weszła w życie ustawa o reformie edukacji ${ }^{11}$, która wprowadziła dwustopniowy systemu szkolnictwa. Powrócono do ośmioletniej szkoły podstawowej oraz

9 Rozporządzenie Ministra Edukacji Narodowej z dnia 12 czerwca 2019 r. zmieniające rozporządzenie w sprawie organizacji roku szkolnego Dz.U. 2019, poz. 1093.

10 W Polsce szkoła podstawowa jest obowiązkowa na mocy Konstytucji, Konstytucja Rzeczypospolitej Polskiej z dnia 2 kwietnia 1997 r., Dz.U. 1997, nr 78, poz. 483. art. 70 1. Nauka do 18 roku życia jest obowiązkowa. 1148.

11 Ustawa z dnia 14 grudnia 2016 r. Prawo oświatowe, Dz.U. 2019, poz. 
szkół ponadpodstawowych. Po ukończeniu szkoły podstawowej uczniowie mogą kontynuować naukę w czteroletnim liceum ogólnokształcącym, pięcioletnim technikum, trzyletniej branżowej szkole pierwszego stopnia, dwuletniej branżowej szkole drugiego stopnia, trzyletniej szkole specjalnej przysposabiającej do pracy oraz szkole policealnej.

W wyniku reformy z 2017 r. trzyletnie zasadnicze szkoły zawodowe zastąpiono dwuletnią szkołą branżową ${ }^{12}$. Wygaszanie gimnazjów przeprowadzono stopniowo i ewolucyjnie. $Z$ dniem 1 września nastąpiła całkowita likwidacja gimnazjów. Obowiązkiem szkolnym objęto dzieci od siódmego roku życia. Kształcenie obowiązkowe dzieci i młodzieży trwa do ukończenia szkoły podstawowej, jednak nie dłużej niż do ukończenia osiemnastego roku życia.

W ramach systemu edukacji w Polsce nie wchodzą uczelnie, które stanowią oddzielny system szkolnictwa wyższego.

\section{System szkolnictwa w Japonii}

Japoński system edukacji jest trzystopniowy, podobnie jak miało to miejsce w Polsce przed 2017 r. Na jego strukturę składają się sześcioletnia szkoła podstawowa (shōgakkō), trzyletnie gimnazjum (chügakkō), trzyletnie liceum (kōtōgakkōa) i uniwersytety (daigaku) (daigaku, 4-letni kurs odpowiadający tytułowi licencjata oraz 2-letni kurs magisterski, daigaku-in) ${ }^{13}$.

Obowiązkiem szkolnym objęci są uczniowie szkół podstawowych oraz gimnazjów w wieku od 6 do 15 lat.

Szkoły ponadgimnazjalne to licea ogólnokształcące i college techniczne. Nauka w szkołach ponadgimnazjalnych nie jest

12 Krótka informacja o polskim systemie edukacji 2017/18, Eurydice, Fundacja Rozwoju Systemu Edukacji, Warszawa 2018, s. 2.

13 Ibidem. 
obowiązkowa. Nauka w liceum trwa 3 lata, zaś w college'ach technicznych 5 do 5,5 roku.

W Japonii rok szkolny trwa od 1 kwietnia do połowy marca, poszczególne cykle nauki oddzielają dwutygodniowe wakacje. Rok szkolny podzielony jest na trzy trymestry. Pierwszy trwa od kwietnia do lipca, drugi od września do grudnia, a trzeci od stycznia do marca. Pomiędzy pierwszym a drugim trymestrem zaplanowane są letnie wakacje, które trwają ok. 1,5 miesiąca (od ok .20 lipca do początku września). Ferie zimowe zaczynają się na koniec drugiego trymestru (od 23 grudnia do 4-7 stycznia) i trwają ok. 2 tygodnie, podobnie jak ferie wiosenne, przypadające pomiędzy końcem i początkiem roku szkolnego (do późnego marca) ${ }^{14}$.

W Japonii w większości szkół prywatnych i państwowych od pierwszej klasy podstawowej do ostatniej w liceum obowiązuje noszenie mundurków.

W Polsce powrotu mundurków chciał minister edukacji Roman Giertych. W 2006 r. w programie ,Zero tolerancji dla przemocy w szkole" dyrektor szkoły miał decydować o wprowadzeniu mundurków.

Rząd koalicyjny PO-PSL w 2007 r. zniósł obowiązek noszenia mundurków. Minister edukacji Katarzyna Hall uważała, że decyzja w tej sprawie miała należeć do szkolnej społeczności.

W Japonii czas wakacji nie jest beztroski dla uczniów. Uczniowie na wakacje mają zadawane prace domowe.

System oświaty w Japonii regulują dwie ustawy z 1947 r. podstawowa ustawa o oświacie" oraz ustawa o szkolnictwie ${ }^{15}$.

W Japonii po II wojnie światowej wprowadzono obowiązek nauki dla dzieci od 6. do 15. roku życia oraz pięciostopniowy system szkolnictwa obowiązujący do dzisiaj. Od tamtego czasu

14 Edukacja w Japonii, „Biuletyn informacyjny”, maj 2016, s. 4.

15 Japoński system edukacji, http://www.japonia.org.pl/?q=pl/node/87 [dostęp: 26.09.2019]. 
przeprowadzono dwie reformy szkolnictwa; z 1992 r. miała na celu wsparcie programów rozwijających w uczniach kreatywność oraz kształcących ich w bardziej globalnym duchu. Druga reforma w 2002 r. była interwencją ze względu na pogarszający się poziom japońskiej edukacji. Nauka trwała pięć dni zamiast sześciu oraz okrojono program nauczania, wprowadzając do niego nowe metody nauczania ${ }^{16}$.

W Japonii przedszkola nie są obowiązkowe. Funkcjonuje prawie 12 tys. przedszkoli (dane z 2015 r.), które podlegają Ministerstwu Edukacji, Kultury, Sportu, Nauki i Technologii. Uczęszczają do nich dzieci w wieku od trzech do pięciu lat ${ }^{17}$.

W Polsce od września 2016 r. edukacja przedszkolna jest nieobowiązkowa dla dzieci od trzeciego do piątego roku życia i obowiązkowa dla 6-latków ${ }^{18}$.

\section{Porównanie systemu edukacji w Polsce i Japonii}

Porównując systemy edukacji w Polsce i Japonii można zauważyć podobieństwa i różnice występujące pomiędzy nimi, co zostało przedstawione w tabeli 1. Dokonując analizy porównawczej zwrócono szczególną uwagę na strukturę sytemu edukacji oraz organy zarządzające oświatą w Polsce i Japonii.

W 2016 r. ambasada Japonii w Polsce wydawała biuletyn poświęcony edukacji w Japonii. Zamieszczono w im wypowiedź córki Japończyka i Polki, Kiyomi, która scharakteryzowała zaangażowanie japońskich uczniów w życie szkolne w następujący sposób: „w Japonii funkcjonuje system dyżurów szkolnych począwszy od szkoły podstawowej, skończywszy na liceum,

16 Edukacja w Japonii, http://miedzykulturowa.org.pl/czytelnia/artykuly/edukacja-w-japonii/ [dostęp: 26.09.2019].

17 Edukacja w Japonii, „Biuletyn informacyjny” , maj 2016, s. 3.

18 Krótka informacja o polskim systemie edukacji 2017/18, Eurydice, Fundacja Rozwoju Systemu Edukacji, Warszawa 2018, s. 3. 
każdego dnia wyznaczani są uczniowie, którzy pomagają przy podawaniu posiłków i sprzątaniu. Wygląda na to, że w Japonii uczymy się sprzątać przez 12 lat. Dodatkowo w japońskiej szkole nauczyciele do uczniów, a także uczniowie między sobą, zwracają się w sposób trochę bardziej formalny niż w Polsce

Tabela 1. Porównanie systemu edukacji w Polsce i Japonii

\begin{tabular}{|c|c|c|}
\hline \multicolumn{3}{|c|}{ Cechy systemu edukacji } \\
\hline Kryterium & $\begin{array}{c}\text { Polska } \\
\end{array}$ & Japonia \\
\hline $\begin{array}{l}\text { Organ } \\
\text { zarządzający } \\
\text { oświatą }\end{array}$ & - Ministerstwo Edukacji Narodowej & $\begin{array}{l}\text { - Ministerstwo Edukacji, Nauki, Spor- } \\
\text { tu i Kultury }\end{array}$ \\
\hline $\begin{array}{l}\text { Obowiązek } \\
\text { szkolny }\end{array}$ & $\begin{array}{l}\text { - dzieci od 7. do 18. roku życia } \\
\text { - ukończona szkoła podstawowa }\end{array}$ & $\begin{array}{l}\text { - dzieci od 6. do } 15 \text {. roku życia } \\
\text { - ukończona szkoła podstawowa i gim- } \\
\text { nazjum }\end{array}$ \\
\hline $\begin{array}{l}\text { Czas trwania } \\
\text { roku szkolnego }\end{array}$ & $\begin{array}{l}\text { - pierwszym dniu września, a kończą } \\
\text { w najbliższy piątek po dniu } 20 \text { czerw- } \\
\text { ca. Jeżeli pierwszy dzień września } \\
\text { wypada w piątek albo sobotę, zajęcia } \\
\text { rozpoczynają się w najbliższy ponie- } \\
\text { działek po dniu } 1 \text { września. } \\
\text { „Jeżeli czwartek bezpośrednio po- } \\
\text { przedzający najbliższy piątek po dniu } \\
20 \text { czerwca jest dniem ustawowo } \\
\text { wolnym od pracy, zajęcia dydaktycz- } \\
\text { no-wychowawcze kończą się w środę } \\
\text { poprzedzającą ten dzień”. } \\
\text { Ferie zimowe trwają dwa tygodnie. } \\
\text { Ferie letnie rozpoczynają się po za- } \\
\text { kończeniu roku szkolnego i trwają do } \\
31 \text { sierpnia. }\end{array}$ & $\begin{array}{l}\text { - W Japonii rok szkolny trwa od } 1 \text { kwie- } \\
\text { tnia do połowy marca, poszczególne } \\
\text { cykle nauki oddzielają dwutygodnio- } \\
\text { we wakacje. Rok szkolny podzielony } \\
\text { jest na trzy trymestry. }\end{array}$ \\
\hline Przedszkole & - dotyczy dzieci w wieku 3-5 lat & - dotyczy dzieci w wieku 3-5 lat \\
\hline $\begin{array}{l}\text { Szkoła } \\
\text { podstawowa }\end{array}$ & $\begin{array}{l}\text { - dotyczy dzieci i młodzieży w wieku } \\
7-15 \text { lat } \\
\text { - ośmioletnia szkoła }\end{array}$ & $\begin{array}{l}\text { - dotyczy dzieci i młodzieży w wieku } \\
\text { 6-12 lat } \\
- \text { sześcioletnia szkoła }\end{array}$ \\
\hline Gimnazjum & - od września 2019 r. likwidacja & - trzyletnie gimnazjum \\
\hline & do wy & boru: \\
\hline Szkoła średnia & $\begin{array}{l}\text { - czteroletnie liceum ogólnokształcące } \\
\text { - pięcioletnie technikum } \\
\text { - trzyletnia szkoła branżowa (pierw- } \\
\text { szego stopnia) } \\
\text { - dwuletnia szkoła branżowa (drugiego } \\
\text { stopnia) } \\
\text { - trzyletnia szkoła specjalna przyspo- } \\
\text { sabiająca do pracy } \\
\text { - szkoła policealna }\end{array}$ & $\begin{array}{l}\text { - trzyletnie liceum } \\
\text { - pięcioletni college techniczny } \\
\text { - pięcioipółletni college techniczny }\end{array}$ \\
\hline $\begin{array}{l}\text { Praca domowa } \\
\text { w wakacje }\end{array}$ & - brak & - zadawana \\
\hline $\begin{array}{l}\text { Mundurek } \\
\text { szkolny }\end{array}$ & - brak obowiązku noszenia & - obowiązek noszenia \\
\hline
\end{tabular}

Źródło: opracowanie własne na podstawie: Edukacja w Japonii, „Biuletyn informacyjny”, grudzień 2010; Edukacja w Japonii, „Biuletyn informacyjny", maj 2016; Krótka informacja o polskim systemie edukacji 2017/18, Warszawa 2018. 
[...] Japońska szkoła różni się od polskiej także tym, że w Japonii nie mamy lektur obowiązkowych. Ponadto dużo czasu musimy poświęcić na naukę pisma, na które składa się kilka tysięcy ideogramów. Nawet w liceum dochodzą nam wciąż nowe znaki i mamy cały czas z nich testy" 19 .

W 2016 r. ambasada Japonii w Polsce wydawała biuletyn poświęcony edukacji w Japonii. Zamieszczono w im wypowiedź córki Japończyka i Polki, Kiyomi, która scharakteryzowała zaangażowanie japońskich uczniów w życie szkolne w następujący sposób: „w Japonii funkcjonuje system dyżurów szkolnych począwszy od szkoły podstawowej, skończywszy na liceum, każdego dnia wyznaczani są uczniowie, którzy pomagają przy podawaniu posiłków i sprzątaniu. Wygląda na to, że w Japonii uczymy się sprzątać przez 12 lat. Dodatkowo w japońskiej szkole nauczyciele do uczniów, a także uczniowie między sobą, zwracają się w sposób trochę bardziej formalny niż w Polsce [...] Japońska szkoła różni się od polskiej także tym, że w Japonii nie mamy lektur obowiązkowych. Ponadto dużo czasu musimy poświęcić na naukę pisma, na które składa się kilka tysięcy ideogramów. Nawet w liceum dochodzą nam wciąż nowe znaki i mamy cały czas z nich testy"20.

System edukacji w Japonii uważany jest na świecie za jeden z najbardziej restrykcyjnych i wymagających ${ }^{21}$.

Dokonując porównania systemów edukacji w Polsce i Japonii można uwzględnić następujące kryteria: organ zarządzający oświatą, obowiązek szkolny, struktura systemu oświaty, czas trwania roku szkolnego, prace domowe, ubiór w szkole. Dzięki tym kryteriom istnieje możliwość dokonania oceny działalności i efektywności szkół podstawowych i ponadpodstawowych.

19 Edukacja w Japonii, „Biuletyn informacyjny”. maj 2016 s. 4.

20 Edukacja w Japonii, „Biuletyn informacyjny”. maj 2016 s. 4.

21 Edukacja w Japonii, http://miedzykulturowa.org.pl/czytelnia/artykuly/edukacja-w-japonii/ [dostęp: 26.09.2019]. 


\section{Podsumowanie}

Coraz częściej można zaobserwować w Polsce i Japonii wzrost oczekiwań społecznych co do jakości kształcenia oraz możliwości swobodnego kontynuowania nauki na każdym etapie życia człowieka. Państwa inwestują w edukację stwarzając możliwość pobierania nauki w każdym wieku.

Porównanie systemów edukacji w Polsce i Japonii daje możliwość zobaczenia mocnych i słabych stron działających systemów. Dzięki tym inwestycjom w system edukacji Polska i Japonia mogą pochwalić się dużą zdawalnością do szkół średnich i wysokim poparciem społecznym dla możliwości kontynuowania edukacji w każdym wieku człowieka.

Dokonując analizy systemów szkolnictwa w Polsce i Japonii można przedstawić różnice występujące pomiędzy nimi.

Udzielając odpowiedzi na pytanie postawione we wstępie artykułu, należy stwierdzić, że w obu państwach istnieje wysokie oczekiwanie społeczne co do możliwości kontynuowania nauki na każdym etapie życia człowieka. W Polsce i Japonii edukacja odbywa się w szkołach publicznych i prywatnych.

Przed wprowadzeniem reformy edukacji w Polsce w 2017 r. system szkolnictwa był trzystopniowy, czyli podobne jak w Japonii.

Należy zauważyć, że jeszcze przed wprowadzeniem reformy edukacji w Polsce w 2017 r. elementem łączącym systemy edukacji w obu państwach były gimnazja. Obecnie jest to element różniący polskie i japońskie szkolnictwo, podobnie jak organizacja roku szkolnego. 


\section{Bibliografia}

\section{Dokumenty}

Konstytucja Rzeczypospolitej Polskiej z dnia 2 kwietnia 1997 r., Dz.U. 1997, nr 78, poz. 483.

Rozporządzenie Ministra Edukacji Narodowej z dnia 11 sierpnia 2017 r. w sprawie organizacji roku szkolnego Dz.U. 2017, poz. 1603.

Rozporządzenie Ministra Edukacji Narodowej z dnia 12 czerwca 2019 r. zmieniające rozporządzenie w sprawie organizacji roku szkolnego Dz.U. 2019, poz. 1093.

Ustawa z dnia 26 stycznia 1982 r. Karta Nauczyciela, Dz.U. 1982, nr 3, poz. 19 z późn. zm.

Ustawa z dnia 7 września 1991 r. o systemie oświaty, Dz.U. 1991, nr 95, poz. 425 z późn. zm.

Ustawa z dnia 8 stycznia 1999 r. Przepisy wprowadzające reformę ustroju szkolnego, Dz.U. 1999, nr 12, poz. 96 z późn. zm. Ustawa z dnia 14 grudnia 2016 r. Prawo oświatowe, Dz.U. 2017, poz. 59 z późn. zm.

\section{Opracowania}

Edukacja w Japonii, „Biuletyn Informacyjny”, grudzień 2010. Edukacja w Japonii, Biuletyn Informacyjny, maj 2016.

Krótka informacja o polskim systemie edukacji 2017/18, Warszawa 2018.

Pachociński R., Zarys pedagogiki porównawczej, Warszawa 1998.

Pęcharski M., Polityka oświatowa, Wrocław 1975.

Průcha J., Pedagogika porównawcza. Podstawy międzynarodowych badań oświatowych, Warszawa 2004.

\section{Źródla internetowe}

Edukacja w Japonii, http://miedzykulturowa.org.pl/czytelnia/ artykuly/edukacja-w-japonii/. 
Japoński system edukacji, http://www.japonia.org.pl/?q=pl/ node/87.

\begin{abstract}
Abstrakt
Celem artykułu jest porównanie systemów edukacji w Japonii i Polsce. Podjęta problematyka mieści się w szerokim nurcie badań porównawczych. Jest ona przedmiotem badań pedagogiki porównawczej, która dąży do przedstawienia i wyjaśniania problemów edukacji na świecie. Wynika to z potrzeby rozwijania i upowszechniania wiedzy o systemach oświatowych w kontekście ich funkcjonowania na świecie. Państwa w ramach swoich kompetencji posiadają dowolność w kształtowaniu kierunku rozwoju szkolnictwa. Systemy edukacji na świecie różnią się między sobą na przykład w zakresie struktury organizacyjnej, procedury egzaminacyjnej oraz programów nauczania. Często państwa przyjmują rozwiązania w zakresie poprawy jakości i efektywności systemu edukacji sprawdzone i przynoszące oczekiwane efekty przez inne państwa.

Do udzielenia odpowiedzi na pytanie badawcze: Jakie są podobieństwa i różnice w systemie edukacji w Polsce i Japonii? autorka wykorzystała metody badawcze: instytucjonalno-prawną, porównawczą oraz statystyczną.

W artykule przedstawiono podobieństwa i różnice pomiędzy systemem edukacji w Polsce a Japonią.
\end{abstract}

Słowa kluczowe: system edukacji, pedagogika porównawcza, polityka edukacyjna, struktura systemu oświaty w Polsce i Japonii

\title{
Abstract
}

The aim of this article is to compare the systems of education in Japan and in Poland. The topic taken up here fits in a broad scope of comparative studies. It is the subject of comparative pedagogy, which aims at presenting and explaining problems of education in the world. It results from the need to develop and make popular the knowledge of education systems in the context of their functioning in the world. Countries within their competences possess freedom of shaping their own direction of development in education. Systems of education in the world differ for example in the scope of organizational structure, 
examination procedure and learning curricula. Quite often countries implement solutions in the field of improving quality and efficiency of educational system that are verified and effective in other countries.

To answer the research question What are similarities and differences between the system of education in Poland and in Japan? the author used institutional and legal, comparative and statistical research methods.

In the article there are presented the systems of education in Poland and in Japan.

Keywords: educational system, comparative pedagogy, educational policy, structure of education system in Poland and in Japan 


\section{Karolina Kalita}

Uniwersytet Wrocławski

\section{„Ie” - japońska rodzina tradycyjna, jej struktura i funkcje}

\section{Wstęp}

Wertując literaturę opisującą charakter japońskiej rodziny współczesnej, można natknąć się na termin „Ie”, np. Joy Hendry pisze, że przeciętne współczesne gospodarstwo domowe może wyglądać w Japonii bardzo podobnie do przeciętnego współczesnego gospodarstwa domowego w wielu innych państwach, jednakże na szczeblu ideologicznym lepiej pasuje doń ów termin „Ie”, zaś Fumie Kumagai, że wiele współczesnych gospodarstw domowych i japońskich rodzin wciąż, w mniejszym lub większym stopniu, posiada cechy owego "I $I e^{" 2}$.

Model gospodarstwa domowego i rodziny Ie ukształtował się w okresie Edo. Pierwotnie był on znany i rozpowszechniony wśród warstw wyższych, tj. w rodzinach arystokratów, szogunatu i wojowników samurajskich ${ }^{3}$. Natomiast nie był znany i rozpowszechniony wśród warstw niższych, tj. w rodzinach

1 J. Hendry, Japończycy. Kultura i społeczeństwo, tłum. T. Tesznar, Kraków 2013, s. 47.

2 F. Kumagai, Families in Japan: Beliefs and Realities, „Journal of Comparative Family Studies” 1995, t. 26, nr 1, s. 139 (tłum. własne).

3 Por. J. Hendry, op.cit., s. 46; A.E. Imamura, Family Culture, [w:] The Cambridge Companion to Modern Japanese Culture, red. Y. Sugimoto, Cambridge-New York-Melbourne-Madrid-Cape Town-Singapore-Sao Paulo-Delhi 2009, s. 77 (tłum. własne); F. Kumagai, op.cit., s. 138. 
kupców, rzemieślników czy chłopów etc. ${ }^{4}$ Chociaż w tamtych czasach nie był w Japonii jedynym istniejącym modelem gospodarstwa domowego i rodziny, a obok niego funkcjonowały także inne, wywarł istotny wpływ na kształt współczesnych, gospodarstw domowych i rodzin. Co za tym idzie, by lepiej rozumieć charakter japońskiej rodziny współczesnej i jej problemy, warto dowiedzieć się czegoś na jego temat.

W niniejszej publikacji omówię Ie, czyli model gospodarstwa domowego i japońskiej rodziny tradycyjnej, jej strukturę i funkcje. Zacznę od omówienia koncepcji Ie, by przejść do struktury rodziny tradycyjnej. Następnie poruszę kwestię znaczenia małżeństwa w rodzinie tradycyjnej. Wreszcie, na samym końcu, omówię układ pozycji i ról w rodzinie tradycyjnej.

\section{Koncepcja Ie}

Termin „Ie” najczęściej tłumaczy się w literaturze przedmiotu dosłownie jako: „dom”, „rodzina” i „ród”. Niemniej jednak kryło/kryje się pod nim znacznie więcej, niż te słowa mogą wskazywać. Pierwotnie nie odnosił się on do jakiejś konkretnej struktury fizycznej, domu czy wspólnoty wszystkich członków, których łączyły ze sobą więzi krwi lub inne. Pierwotnie kryła się pod nim pewna koncepcja ${ }^{6}$. Zakładała ona istnienie określonego zestawu pozycji i ról, definiowała odpowiedzialność i obowiązki poszczególnych aktorów - członków Ie, a także wyznaczała im wartości, które miały być pielęgnowane przez

4 F. Kumagai, op.cit.

5 Por. J. Hendry, op.cit., s. 47; Japan. Profile of a Nation, Tokyo-New York-London 1994, s. 314 (tłum. własne); F. Kumagai, op.cit.; Y. Sugimoto, An Introduction to Japanese Society, Cambridge-New York-Melbourne-Madrid-Cape Town-Singapore-Sao Paulo 2002, s. 147 (tłum. własne).

6 E. Cooper Masuoka et al., Role Conflicts in the Modern Japanese Family, „Social Forces” 1962, t. 41, nr 1, s. 1 (tłum. własne). 
nich, i standardy, które miały być utrzymywane7. Wraz z upływem czasu zaczęto posługiwać się nim nie tylko w odniesieniu do gospodarstwa domowego, ale także do samej rodziny. Natomiast obecnie badacze posługują się nim nie tylko w odniesieniu do gospodarstw domowych i rodzin z okresu Edo, ale także do współczesnych gospodarstw domowych i rodzin tradycyjnych ${ }^{8}$.

Można spotkać się w literaturze przedmiotu z definicjami nawiązującymi do struktury Ie, które podają, że jest to np. „kompleks rodzin nuklearnych pionowo układany, po jednej z każdego pokolenia” czy „seria pierwszych synów, ich żon i ich małoletnich dzieci" ${ }^{\prime \prime}$. Niemniej jednak jednocześnie jest to także gospodarstwo domowe, którego członkowie mają do odegrania jasno określone role mające na celu jego utrzymanie ${ }^{10}$. Sens Ie, moim zdaniem, najpełniej oddaje Anne E. Imamura:

Ie to opierające się na zasadach hierarchii płci i wieku oraz ciągłości pokoleniowej, patriarchalne, patrylinealne, nastawione na produkcję i reprodukcję gospodarstwo domowe, w którym praca i obowiązki były rozdzielane pomiędzy jego członków według ich pozycji i płci ${ }^{11}$.

Ie bazowało na często nieuświadomionych zasadach życia społecznego, identyfikacji z własną grupą oraz postępowaniu zgodnym z jej interesami i zasadami ${ }^{12}$. Zasadniczo zapewniało ono spójność społeczną, wytyczne oraz wsparcie rodzinom i poszczególnym jednostkom ${ }^{13}$. Było ze wszystkich stron pod-

7 Ibidem.

8 Japan. Profile of a Nation, op.cit., s. 314.

9 F. Kumagai, [za:] K. Morioka, T. Lebra, E. Johnson, op.cit., s. 138.

10 F. Kumagai, op.cit., s. 138.

11 A.E. Imamura, op.cit., s. 77.

12 S. Hall Vogel, Japanese Society under Stress. Diagnosis and Prescription, „Asian Survey” 2012, t. 52, nr 4, s. 697 (tłum. własne).

13 Ibidem. 
pierane wartościami religijno-etycznymi ${ }^{14}$. Jego stabilność była uzależniona od stabilności kultury i szerszej społeczności ${ }^{15}$.

Podstawowymi obowiązkami członków Ie były zachowanie jego ciągłości i dbanie o nie, uważane za ważniejsze od ich interesu prywatnego. Dzięki nieprzerwanej sukcesji grup rodowych miało trwać ono wiele pokolen ${ }^{16}$. Relacje pomiędzy nimi i pomiędzy nimi a innymi zbiorowościami regulowano w oparciu o przypisaną im pozycję ${ }^{17}$. Kasan (majątek rodzinny) był podstawą ich bytu. Co więcej, zazwyczaj jakieś konkretne zajęcie wiązało się z każdym Ie i mieli oni obowiązek, na miarę swoich możliwości, uczestniczyć w nim. Niemniej jednak nie otrzymali za wykonywaną pracę wynagrodzenia indywidualnego, ale wspólnie korzystali z zysków przynoszonych przez $n^{18}{ }^{18}$. Natomiast podstawowym sensem ich przynależności do niego było zapewnienie sobie udziału w dobrobycie zbiorowym $^{19}$. Co za tym idzie, byli zobowiązani do dbania na łonie szerzej rozumianej społeczności o jego pozycję. Można było wykluczyć z niego jednostkę, która przyczyniła się lub mogła przyczynić do jego zhańbienia ${ }^{20}$.

W 1868 r. okres Edo dobiegł końca. Oficjalnie zniesiono system klasowy. Co za tym idzie, samuraje zostali zrównani z resztą społeczeństwa ${ }^{21}$. Następnie scentralizowano system polityczny wokół cesarza ${ }^{22}$. Wtedy też dorobiono do Ie ideologię narodową.

\footnotetext{
14 E. Cooper Masuoka et al., op.cit., s. 1.

15 Ibidem.

16 Por. E. Cooper Masuoka et al., op.cit.; J. Hendry, op.cit., s. 48.

17 E. Cooper Masuoka et al., op.cit.

18 J. Hendry, op.cit., s. 48.

19 E. Cooper Masuoka et al., op.cit., s. 1.

20 J. Hendry, op.cit., s. 48.

21 F. Kumagai, op.cit., s. 139.

22 S. Shirai, How Psychotherapist Can Assist People in Difficult Situations in Present Day Japanese Society. Focusing upon the Issue of Hikikomori (Social Withdrawal), „Teologia. Diakonia” 2004, t. 38, s. 105 (tłum. własne).
} 
Uznano je za pojedynczy organizm społeczny ${ }^{23}$. I tak wszystkie rodziny, nie tylko z klas wyższych, ale także te z niższych, miały bezpośrednio podlegać jemu ${ }^{24}$.

Centralizacja władzy w rękach cesarza i zjednoczenie wokół niego wszystkich obywateli przyczyniły się do upowszechnienia w Japonii modelu gospodarstwa domowego i rodziny wzorowanego na $I e^{25}$. Zyskawszy wolność, ludzie z klas niższych zapragnęli naśladować obyczaje klasy panującej ${ }^{26}$. Model gospodarstwa domowego i rodziny Ie wydawał się im godnym naśladowania ${ }^{27}$. W 1898 r. Kodeks cywilny Meiji wszedł w życie ${ }^{28}$. Wyselekcjonowano pewne elementy Ie, prawnie usankcjonowano i zaczęto odnosić do wszystkich obywateli ${ }^{29}$. Pojawiło się nowe pojęcie - Kazoku, które można przetłumaczyć dosłownie jako „rodzina” ${ }^{30}$. Przez Koseki (rejestr rodzinny) zawierający informacje dotyczące: dat urodzeń, zgonów i małżeństw poszczególnych jej członków administracyjnie zdefiniowano strukturę Kazoku. Stał się on dokumentem cywilnym potwierdzającym przynależność do niej ${ }^{31}$. Tak więc natura Ie uległa zmianie, co znacząco wypłynęło na wszystkie aspekty życia Japończyków.

\section{Struktura rodziny tradycyjnej}

Do połowy XX w. Japonia była państwem rodzin wielopokoleniowych, wzorowanych na Ie. Zazwyczaj wszyscy członkowie

23 E. Cooper Masuoka et al., op.cit., s. 1.

24 Por. F. Kumagai, op.cit., s. 139; S. Shirai, op.cit., s. 105.

25 S. Shirai, op.cit., s. 105-106.

26 L. Frédéric, Życie codzienne w Japonii u progu nowoczesności, tłum. E. Bąkowska, Warszawa 1988, s. 128.

27 Ibidem.

28 F. Kumagai, op.cit., s. 139.

29 A.E. Imamura, op.cit., s. 78.

30 Por. A.E. Imamura, op.cit.; Japan. Profile of a Nation, op.cit., s. 314.

31 A.E. Imamura, op.cit. 
takich rodzin zamieszkiwali pod jednym dachem. A dokładniej - z dziadkiem w jego domu zamieszkiwali: jego żona, żonaty Chōnan (najstarszy syn) lub rzadziej zamężna córka i ich dzie$\mathrm{ci}^{32}$. Notabene posiadanie więcej niż dwójki dzieci było w nich na porządku dziennym ${ }^{33}$. Co więcej, należeli doń nie tylko poszczególni żyjący mieszkańcy danego domu, którzy niekoniecznie musieli mieszkać w nim przez całe życie, ale także ich wszyscy poprzednicy: bliscy przodkowie, którzy w niedawnej przeszłości zmarli, dalecy przodkowie, o których wciąż jeszcze pamiętano, dalecy przodkowie, którzy już zostali zapomniani jako jednostki, i jeszcze nienarodzeni potomkowie ${ }^{34}$. Dbanie o to, by po śmierci przodków nie przestała istnieć, ale także kultywowanie pamięci o nich było obowiązkiem jej żyjących członków ${ }^{35}$.

\section{Znaczenie małżeństwa w rodzinie tradycyjnej}

Już w czasach starożytnych ze względu na to, że małżeństwo sankcjonowało rzeczywisty udział w życiu społecznym, należało ono w Japonii do rzeczy najbardziej istotnych w życiu człowieka. Dlatego też nigdy nie było wyłączną sprawą dwóch osób, ale sprawą całych rodzin ${ }^{36}$. Co za tym idzie, nie było dobrowolnie zawierane, jako rezultat ich miłości i wyboru indywidualnego, ale na zasadzie umowy pomiędzy dwoma Ie zawieranej przez

32 Por. L. Ellington, Japan. A Global Studies Handbook, Santa Barbara-Denver-Oxford 2002, s. 165 (tłum. własne); S.W. Morton, K.J. Olenik, Japan. Its History and Culture, Fourth Edition, New York-Chicago-San Francisco-Lisbon-London-Madrid-Mexico City-Milan-New Delhi-San Juan-Seoul-Singapore-Sydney-Toronto 2005, s. 269 (tłum. własne).

33 L. Ellington, op.cit.

34 J. Hendry, op.cit., s. 47.

35 Ibidem.

36 Por. L. De Mente Boyé, The Japanese Have a Word for It. The Complete Guide to Japanese Thought and Culture, Chicago 1997, s. 252 (tłum. własne); L. Frédéric, op.cit., s. 126. 
ich głowy ${ }^{37}$. Dobierając do siebie osoby o podobnym pochodzeniu i pozycji, aranżowano zdecydowaną większość z nich ${ }^{38}$.

Zawarcie małżeństwa oznaczało dla kobiet odejście ze swojego Ie i dołączenie do Ie męża, zaś dla mężczyzn przyjęcie żony do swojego $I e^{39}$. Zasada patrylokacji, czyli zamieszkanie w domu pana młodego, miała zapewnić mu ciągłość i długowiecznośćc ${ }^{0}$. W przypadku $I e$, w których były tylko córki, gdy najstarsza z nich zawarła małżeństwo, jej mąż stawał się częścią jej $I e$, a czasami nawet przyjmował jej nazwisko. Natomiast młodsi synowie i córki po zawarciu małżeństwa odchodzili od swoich Ie pierwotnych, dołączali do innych i już nie uważano ich za członków tych pierwszych ${ }^{41}$.

Po zawarciu małżeństwa Yome (żona) stawała się pełnoprawnym członkiem Ie męża ${ }^{42}$. Niemniej jednak zawsze można było odesłać niezadowalającą Yome do jej Ie pierwotnego i zwrócić jej rodzicom, co było jednoznaczne z rozpoczęciem poszukiwań nowej panny młodej ${ }^{43}$. Słabe zdrowie, domniemana bezpłodność, nieposłuszeństwo, nieprzystosowanie, zazdrość czy gadulstwo kobiety etc. - istniało wiele powodów, które mogły stanowić dla mężczyzn pretekst wystarczający do

37 Por. F. Adamski, Rodzina. Wymiar społeczno-kulturowy, Kraków 2002, s. 75; A.E. Imamura, op.cit., s. 77; L.G. Martin, S. Culter, Mortality Decline and Japanese Family Structure, "Population and Development Review" 1983, t. 9, nr 4, s. 634 (tłum. własne).

38 Por. L. Ellington, op.cit., s. 165; J. Hendry, op.cit., s. 62.

39 Por. F. Adamski, op.cit., s. 75; L.G. Martin, S. Culter, op.cit., s. 634.

40 F. Adamski, op.cit.

41 L. Ellington, op.cit., s. 165.

42 F. Adamski, op.cit., s. 75.

43 Por. L. De Mente Boyé, op.cit., s. 252; J. Hendry, op.cit., s. 49; A.E. Imamura, op.cit., s. 77; Japan. Profile of a Nation, op.cit., s. 314; K. Okazaki, Kobiety i mężczyźni w Japonii - rozdział stref działania, [w:] Być kobieta $w$ Oriencie, red. D. Chmielowska, B. Grabowska, E. Machut-Mandecka, Warszawa 2008, s. 128. 
podjęcia takiej decyzji ${ }^{44}$. Co więcej, mężczyźni mogli podjąć taką decyzję nawet wtedy, gdy ich żona, która np. zachorowała i stała się niezdolna do dalszego pełnienia swoich obowiązków, już była w wieku średnim ${ }^{45}$. Natomiast kobiety mogły żądać rozwodu tylko wtedy, gdy ich mąż porzucił je lub popełnił jakieś poważne przestępstwo ${ }^{46}$. Ponadto mężczyźni mogli mieć konkubiny, zaś kobiety karano za zdradę śmiercią ${ }^{47}$.

\section{Układ pozycji i ról w rodzinie tradycyjnej}

Samuraje byli przesiąknięci autorytarnym i pruderyjnym konfucjanizmem ${ }^{48}$. Relacje pomiędzy członkami ich rodzin i rodów były hierarchicznie uporządkowane stosownie do takich wyznaczników, jak: wiek, płeć czy przewidywany czas pobytu w siedzibie ${ }^{49}$. Ponieważ taki model powszechne przyjęto, wraz z upływem czasu także relacje pomiędzy członkami rodzin klas niższych stały się hierarchicznie uporządkowane i ustabilizowane. Przestały być one jednostkami produkcji i konsumpcji, w których panowały relacje egalitarne ${ }^{50}$.

Patriarchalna głowa stała na szczycie hierarchii Ie, zaś jego pozostali członkowie, przywiązani do niej przez prawdziwe lub symboliczne więzi krwi - niżej ${ }^{51}$. Wszyscy oni byli podporząd-

\footnotetext{
44 Por. J. Hendry, op.cit.; Japan. Profile of a Nation, op.cit.; K. Okazaki,

45 J. Hendry, op.cit.

46 K. Okazaki, op.cit., s. 128.

47 Ibidem.

48 L. Frédéric, op.cit., s. 128.

49 J. Hendry, op.cit., s. 48.

50 Por. Japan. Profile of a Nation, op.cit., s. 314; F. Kumagai, op.cit.,

51 Y. Sugimoto, op.cit., s. 147.
} op.cit. s. 139. 
kowani jemu jako całości ${ }^{52}$. Relacje pomiędzy nimi charakteryzowały konfucjańskie ideały lojalności i życzliwości. Uważano, że w zamian za otrzymane dobrodziejstwa młodsi są winni starszym wdzięczność. Co za tym idzie, w zamian za swoje wychowanie dzieci miały obowiązek być lojalnymi wobec rodziców. Oczekiwano, że gdy już nie będą oni w stanie sami zadbać o siebie, będą opiekować się one nimi ${ }^{53}$. Innymi słowy, cechowała je nie tyle miłość, ile raczej poczucie obowiązku i oddanie synowskie ${ }^{54}$. Mężczyźni wyżej stali w hierarchii Ie niż kobiety, jednakże mieli oni obowiązek zaspokajać ich wszystkie potrzeby ${ }^{55}$.

Obierano w każdym pokoleniu Ie jednego, stałego dziedzica i pozyskiwano dlań małżonkę, mającą dzielić z nim obowiązek jego przedłużania. Pozostali przedstawiciele danego pokolenia mogli przebywać w domu lub powrócić doń. Niemniej jednak, jeżeli zawarli małżeństwo, oczekiwano od nich, że się wyprowadzą ${ }^{56}$.

\subsection{Pozycja i rola Kachō (głowy rodu, męża i ojca)}

Kachō (głowy rodu, ojcowie) byli społecznymi, ekonomicznymi, moralnymi oraz prawnymi liderami i zwierzchnikami $I e^{57}$. W świetle prawa dysponowali oni nad nimi władzą niekwe-

\footnotetext{
52 L.G. Martin, S. Culter, op.cit., s. 634.

53 J. Hendry, op.cit., s. 48.

54 Ibidem.

55 Ibidem, s. 62.

56 Ibidem.

57 Por. E. Cooper Masuoka et al., op.cit., s. 1; Japan. Profile of a $\mathrm{Na}$ tion, op.cit., s. 314; D.W. Shwalb et al., Fathering in Japan, China and Korea. Changing Contexts, Images and Roles, [w:] The Role of the Father in Child Development, red. M.E. Lamb, New Jersey 2010, s. 345 (tłum. własne).
} 
stionowaną i niemal absolutną ${ }^{58}$. Mieli stać na straży ich ciągłości, gwarantować ich status społeczny i dobrobyt oraz zachować pomiędzy Bunke (gałęziami rodu) powiązanymi z nimi $W a(\text { harmonię })^{59}$. Mieli przewodzić ich wszystkim członkom $\mathrm{w}$ życiu, ale także odpowiadać za nich ${ }^{60}$. Ich uprawnienia obejmowały nawet sferę ich życia i śmierci ${ }^{61}$. Rządzenie nimi, rozkazywanie im, kontrolowanie ich zachowania, przewodzenie im w życiu i otaczanie ich opieką były nie tylko ich prawem, ale wręcz obowiązkiem ${ }^{62}$.

Credo konfucjańskie Genpu Jibo („Wymagający ojciec, łagodna matka") zachęcało Kachō do surowego dyscyplinowania swoich dzieci i utrzymywania wobec nich stosownego dystansu $^{63}$. Z racji odpowiedzialności za trwanie Ie przyznano im pełne prawo do dokonywania wyboru ich małżonków oraz regulowania ich małżeństw i rozwodów ${ }^{64}$. Zgodnie z Kodeksem cywilnym Meiji mieli oni nie tylko prawo, ale wręcz obowiązek prawny zatwierdzać ich małżeństwa do czasu, kiedy synowie osiągną wiek 30 lat, a córki 25 lat, i określać, kto zostanie wpisany do Koseki ${ }^{65}$. Co więcej, mieli także prawo, a wręcz obowiązek prawny podejmować wszelkie decyzje dotyczące dziedziczenia i wydziedziczania ${ }^{66}$.

58 Por. L. Frédéric, op.cit., s. 128; J. Hendry, op.cit., s. 48; Japan. Profile of a Nation, op.cit.; Y. Sugimoto, op.cit., s. 147-148.

59 Por. F. Adamski, op.cit., s. 74; E. Cooper Masuoka et al., op.cit., s. 2.

60 Por. L. Frédéric, op.cit., s. 128; J. Hendry, op.cit., s. 48; Y. Sugimoto, op.cit., s. 147-148.

61 F. Adamski, op.cit., s. 74.

62 Por. F. Adamski, op.cit.; A.E. Imamura, op.cit., s. 77.

63 J. Nakazawa, D.M. Schwalb, Fathering in Japan: Entering an Era of Involvement with Children, [w:] Fathers in Cultural Context, red. D.W. Schwalb, B.J. Schwalb, M.E. Lamb, New York 2013, s. 44 (tłum. własne).

64 Por. E. Cooper Masuoka et al., op.cit., s. 2; Y. Sugimoto, op.cit., s. 148.

65 A.E. Imamura, op.cit., s. 78.

66 E. Cooper Masuoka et al., op.cit., s. 2. 
Autorytet Kachō nie był osadzony na jego cechach moralnych czy osobowych, ale na tradycji społeczno-moralnej i prawie rodzinnym. Co za tym idzie, ze wszystkich stron osaczano Kachō realizujących swoje prawa i obowiązki ograniczeniami nie tylko społeczno-moralnymi, ale także instytucjonalnymi, np. pomimo tego, że dysponowali oni prawem do zarządzania Kasan, jako osoby odpowiedzialne zań, nie byli wolnymi agentami. Im większy Kasan, tym wyższy status Ie i tym większe obowiązujące ich ograniczenia ${ }^{67}$.

Zasada oddania synowskiego zalecała w imię dobra Ie jego wszystkim członkom absolutne posłuszeństwo, oddanie i cześć $K a c h{ }^{68}$. Co za tym idzie, przynajmniej teoretycznie cieszyli się oni wśród nich szacunkiem ${ }^{69}$. Z racji znaczenia roli przysługiwały im pewne przywileje z ich strony, chociażby takie, jak np. pierwszeństwo obsługi przy posiłkach czy brania kąpieli ${ }^{70}$.

\subsection{Pozycja i rola Chōnana (najstarszego syna)}

Istnienie i kontynuacja Ie zależały od istnienia potomka męskiego. A dokładniej - z pokolenia na pokolenie przenoszono zwierzchnictwo i władzę nad nim przez primogeniturę, czyli pierworództwo. Przejmował je Chōnan ${ }^{71}$. Niemniej jednak czasem zdarzało się, że przejmował je młodszy syn zdolniejszy od niego, a nawet ktoś z zewnątrz ${ }^{72}$. Ponadto istniały odstęp-

67 Por. F. Adamski, op.cit., s. 74; E. Cooper Masuoka et al., op.cit., s. 2.

68 Por. F. Adamski, op.cit.; E. Cooper Masuoka et al., op.cit.; J. Nakazawa, D.W. Schwalb, op.cit., s. 44.

69 S. Shirai, op.cit., s. 106.

70 J. Hendry, op.cit., s. 48.

71 Por. F. Adamski, op.cit., s. 74; J. Hendry, op.cit.; Japan. Profile of a Nation, op.cit., s. 314; F. Kumagai, op.cit., s. 138; Y. Sugimoto, op.cit., s. 148.

72 Por. A.E. Imamura, op.cit., s. 77; Japan. Profile of a Nation, op.cit. 
stwa regionalne od tej reguły, np. w niektórych okręgach na północy Japonii pierworodne dziecko, bez względu na jego płeć, było dziedzicem, a w niektórych rejonach Kyūshū był nim najmłodszy syn ${ }^{73}$. W przypadku jego choroby czy niezdolności do objęcia władzy nad Ie jego prerogatywy przechodziły na kolejnego syna, wedle kolejności urodzenia ${ }^{74}$.

Chōnanowie byli nazwani Atotori (następcami) lub Atotsugi (następcami zwierzchników) ${ }^{75}$. Będąc domniemanymi dziedzicami, zajmowali oni w hierarchii Ie drugą pozycję po Kach $\bar{o}^{76}$. Zdobywali ją nie tylko ze względu na kolejność urodzenia, ale także wykazując, że są w stanie poradzić sobie z zarządzaniem $\operatorname{nim}^{77}$. Mieli wziąć na siebie odpowiedzialność za jego dalsze utrwalanie i ochronę jego pozostałych członków ${ }^{78}$. Mieli (wraz z małżonkami) wziąć na siebie odpowiedzialność także za opiekę nad swoimi rodzicami, gdy ci już się zestarzeją ${ }^{79}$. Co więcej, dziedziczyli $\mathrm{Kasan}^{80}$. Niemniej jednak dziedziczone dobra, oprócz dóbr zdobytych na własną rękę, nie stawały się ich własnością w całym tego słowa znaczeniu. Mieli być jedynie ich zarządcami zobowiązanymi do tego, by utrzymać je i w stanie

73 J. Hendry, op.cit., s. 49.

74 F. Adamski, op.cit., s. 74.

75 Por. E. Cooper Masuoka et al., op.cit., s. 2; H. Kitaōji, The Structure of the Japanese Family, „American Anthropologist. New Series” 1971, t. 73, nr 5, s. 1037 (tłum. własne).

76 Por. E. Cooper Masuoka et al., op.cit.; A.E. Imamura, op.cit., s. 77; S. Shirai, op.cit., s. 106.

77 A.E. Imamura, op.cit., s. 77.

78 Por. Japan. Profile of a Nation, op.cit., s. 314; L.G. Martin, S. Culter, op.cit., s. 634.

79 Por. A. Fogel, M. Kawai, Hikikomori in Japanese Youth: Some Possible Pathways for Alleviating this Problem from the Perspective of Dynamic Systems Theory, [w:] Nyūyōji Hattatsu Rinshō Senta-Nenpō, Annual Report 28 marca 2006, s. 5 (tłum. własne); A.E. Imamura, op.cit., s. 77.

80 Por. J. Hendry, op.cit., s. 48; A.E. Imamura, op.cit.; L.G. Martin, S. Culter, op.cit. s. 634; Y. Sugimoto, op.cit., s. 148. 
nietkniętym przekazać następnym pokoleniom, a także przyczynić się do ich poprawy ${ }^{81}$. Ponadto oczekiwano od nich, że będą zachowywali się zgodnie z przypisaną im pozycją ${ }^{82}$. Ze względu na nią, a także ze względu na największą ilość obowiązków przysługiwały im szacunek, przywileje i specjalne traktowanie ${ }^{83}$.

Później, w okresie Meiji, ustanowiono prawo nakazujące przekazać majątek rodzinny jednemu wybranemu dziedzicowi, który miał wziąć na siebie odpowiedzialność za opiekę nad swoimi rodzicami, cześć przodków i utrzymanie ich grobów ${ }^{84}$. Niemniej jednak w praktyce życia codziennego przywództwo wciąż przenoszono w większości rodzin na Chōnanów ${ }^{85}$.

Pozycje przypisywane Jinanom i Sannanom (drugim i trzecim synom) były od przypisywanej Chōnanom odpowiednio niższe. Nazywano ich Hiyameshi Kui (dosłownie: „osobami jadającymi zimny ryż”), co miało ten fakt podkreślić. Pomimo tego, że wyłączano ich z dziedziczenia, zobowiązywani byli do realizacji przydzielanych im obowiązków. W zamian mogli oczekiwać pomocy w tworzeniu Bunke podporządkowanych $K a c h o ̄$, na których czele stawali ${ }^{86}$.

\subsection{Pozycje i role Yome (żony) i Shiūtome (matki głowy rodu, teściowej)}

W okresie Edo swoboda kobiet została znacznie ograniczona. Anonimowe dzieło stworzone w duchu konfucjanizmu pt.

\footnotetext{
81 Por. F. Adamski, op.cit., s. 74-75; A.E. Imamura, op.cit.

82 E. Cooper Masuoka et al., op.cit., s. 2.

83 Ibidem.

84 A.E. Imamura, op.cit., s. 78.

85 F. Kumagai, op.cit., s. 139.

86 Por. E. Cooper Masuoka et al., op.cit., s. 2; J. Hendry, op.cit., s. 49; L.G. Martin, S. Culter, op.cit., s. 634; Y. Sugimoto, op.cit., s. 148.
} 
Onna Daigaku (Wielka nauka dla kobiet) doskonale nakreśliło jej ramy ${ }^{87}$. Kobiety powinny były być pokorne i powściągliwe. Powinny były także wyrzec się życia osobistego na rzecz mężów, teściów i dzieci ${ }^{88}$. Nałożono na nie trzy rodzaje zależności: bezwzględną uległość oraz posłuszeństwo wobec ojców, mężów i ich rodziny, a później, gdy już owdowieją, wobec swoich dorosłych synów $^{89}$. W okresie Meiji i później, w latach wojny i ekspansji imperialnej, ich znaczenie wzrosło. Innymi słowy, podczas gdy wraz z upływem czasu mężczyźni i kobiety, mężowie i żony w innych państwach stawali się sobie równi, autorytet i znaczenie Kachō w Japonii stale rosły, zaś kobiety i żony traciły niezależność, a ich pozycja stawała się coraz słabsza i coraz bardziej kwestionowa$\mathrm{na}^{90}$.

Po wyjściu za mąż kobiety występowały ze swoich Ie pierwotnych, a następnie dołączały one do Ie mężów ${ }^{91}$. Narzucano im względem nich pozycje niższe i zmuszano je do podporządkowania się ${ }^{92}$. Co więcej, zmuszano je także do podporządkowania się Shiūtome (matkom głowy rodu, teściowym) ${ }^{93}$. Ślepe posłuszeństwo wobec Ie i Shiütome były postrzegane jako ich cnoty najważniejsze ${ }^{94}$. Ponadto zmuszano je także do podporządkowania się wszystkim pozostałym członkom $I e^{95}$. Tym sa-

87 K. Okazaki, op.cit., s. 128.

88 Por. L. Frédéric, op.cit., s. 133; K. Okazaki, op.cit.

89 Por. J. Hendry, op.cit., s. 62-63; S.W. Morton, K.J. Olenik, op.cit., s. 271; K. Okazaki, op.cit.

90 Por. L. Frédéric, op.cit., s. 129; S.W. Morton, K.J. Olenik, op.cit.

91 Por. F. Adamski, op.cit., s. 75; L. Ellington, op.cit., s. 165; L.G. Martin, S. Culter, op.cit., s. 634.

92 Por. L. Frédéric, op.cit., s. 128; J. Hendry, op.cit., s. 48; A.E. Imamura, op.cit., s. 77.

93 Por. J. Hendry, op.cit.

94 E. Cooper Masuoka et al., op.cit., s. 2.

95 Ibidem. 
mym, wchodząc do nich, zajmowały w ich hierarchii pozycje najniższe ${ }^{96}$.

Ogólnie rzecz biorąc, pozycja kobiet w hierarchii Ie była niska, jednakże Shufu (gospodynie) cieszyły się wśród pozostałych jego członków płci żeńskiej dobrą pozycją ${ }^{97}$. Niemniej jednak, by ją osiągnąć, uprzednio musiały one wiele przejść. A dokładniej - istniały dwa etapy ich funkcjonowania w Ie mężów: etap Yome (etap żony) i etap Shiūtome (etap matki głowy rodu, teściowej) $)^{98}$.

Na pierwszym z nich, zawarłszy małżeństwo z dziedzicem i stawszy się nowymi członkami Ie, przez pewien czas Yome doświadczały wielkiego napięcia w relacjach z nowymi krewnymi. Najbardziej krytyczne dotyczyło ich relacji z Shiūtome ${ }^{99}$, albowiem pomimo tego, że zazwyczaj małżeństwa zawierano pomiędzy Ie o podobnym statusie, uważano, że każde z nich ma swoje własne zwyczaje oraz praktyki i przybysz z zewnątrz musi dostosować się do nich ${ }^{100}$. I tak pod czujnym okiem Shiūtome rozpoczynały one trening. Oczekiwano, że będą wstawały pierwsze i kładły się spać ostatnie, że będą ciężko pracowały oraz że będą produkowały kolejnych dziedziców, którzy zapewnią Ie ciągłość ${ }^{101}$. Szczególnie w pierwszych latach małżeństwa musiały wykazać się gotowością do świadczenia usług na każde skinienie pozostałych członków Ie. Zajmowały się m.in. gotowaniem, sprzątaniem czy praniem. Co więcej, ponieważ przez większą część dnia małe dzieci mogły pozostawać pod opieką mniej sprawnych członków rodziny, brały udział w prowadzeniu in-

\footnotetext{
96 Por. A.E. Imamura, op.cit., s. 77; S. Shirai, op.cit., s. 106.

97 E. Cooper Masuoka et al., op.cit., s. 2.

98 Ibidem.

99 Por. E. Cooper Masuoka et al., op.cit.; J. Hendry, op.cit., s. 49, 63.

100 J. Hendry, op.cit., s. 49.

101 Por. E. Cooper Masuoka et al., op.cit., s. 2; L. Frédéric, op.cit., s. 132; A.E. Imamura, [za:] S. Nolte, S. Hastings, op.cit., s. 77.
} 
teresu rodzinnego ${ }^{102}$. Często Shiūtome nadużywały wobec nich swojej pozycji. Szykanowały je i przydzielały im najgorszą pracę. Innymi słowy, w praktyce po wyjściu za mąż Yome stawały się niewolnicami teściów i męża oraz służącymi we własnym domu. Cokolwiek by zrobiły, nigdy nie przyznawano im słuszności ${ }^{103}$.

Na drugim z nich, po latach uległości i posłuszeństwa, Yome osiągały status $S h u f u^{104}$. Ich pozycje stawały się bezpieczne zwłaszcza wtedy, gdy w sposób zadowalający wypełniły one wszystkie oczekiwania pozostałych członków Ie i same stały się Shiütome ${ }^{105}$.

Córki Shiūtome zajmowały w hierarchii Ie pozycje niższe niż Shiūtome, jednakże wyższe niż Yome. Ponieważ jednak pewnego dnia miały wyjść one za mąż i przejść do innych $I e$, ich pobyt $\mathrm{w}$ Ie pierwotnym postrzegano jako tymczasowy. Co za tym idzie, także one były przez Shiūtome „odpowiednio trenowane". Nie tylko trening w domu rodzinnym, ale także i w społeczności przygotowywał je do zajmowania wyznaczonych im miejsc jako Yome w innych $I e^{106}$.

Miłość pomiędzy mężem a żoną uważano za niezgodną z nakazem oddania synowskiego. Yome powinny były w pierwszej kolejności zwracać uwagę na potrzeby rodziców męża i swoich dzieci, a dopiero później na potrzeby jego samego ${ }^{107}$. Co za tym idzie, miały łączyć je z nim niezbyt zażyłe relacje. Oczekiwano, że nie będą okazywały mu żadnych uczuć, że będą przejawiały wobec niego postawę chłodną. Uważano, że zbytnie spoufalanie jest szkodliwe ${ }^{108}$. Zresztą sami mężowie oczekiwali od

\footnotetext{
102 Por. J. Hendry, op.cit., s. 63; S.W. Morton, K.J. Olenik, op.cit., s. 272.

103 L. Frédéric, op.cit., s. 132.

104 Por. E. Cooper Masuoka et al., op.cit., s. 2; L. Frédéric, op.cit., s. 129.

105 E. Cooper Masuoka et al., op.cit.

106 Ibidem, s. 2-3.

107 Por. J. Hendry, op.cit., s. 62; L.G. Martin, S. Culter, op.cit., s. 634.

108 Por. E. Cooper Masuoka et al., op.cit., s. 2; J. Hendry, op.cit., s. 48.
} 
żony nie uczuć, ale tego, że będzie posiadała ona kompetencje w zarządzaniu sprawami wewnętrznymi Ie, jednakże oczywiście niezbyt, oraz będzie potrafiła robić to, jednocześnie zachowując pomiędzy sobą i Shiūtome Wa. Natomiast żony mogły oczekiwać od męża tego, że właściwie odegra on w Ie swoją rolę i że zachowa w nim $W^{109}$. Te, które już urodziły dzieci, miały wziąć na siebie odpowiedzialność za ich wychowywanie. Będąc matkami, miały być bliżej nich oraz zapewniać im ochronę i wsparcie ${ }^{110}$. Ponadto miały wziąć na siebie odpowiedzialność za opiekę nad rodzicami męża aż do ich śmierci i za szkolenie w zwyczajach domowych swoich następczyń ${ }^{111}$. Innymi słowy, tradycja ograniczała rolę kobiet do przeznaczenia ich małżeństwu, domowi, dzieciom oraz do całkowitego poświęcenia życia rodzinie i małżonkowi ${ }^{112}$. Co za tym idzie, pozostawało im niewiele czasu na działalność poza rodziną ${ }^{113}$.

Dzieci należały nie do matek, ale do $I e^{114}$. Oczekiwano od nich, że będą szanowały rodziców i do końca życia będą posłuszne ich woli ${ }^{115}$.

\section{Podsumowanie}

W niniejszej publikacji omówiłam Ie, czyli model gospodarstwa domowego i japońskiej rodziny tradycyjnej, jej strukturę i funkcje.

109 Por. E. Cooper et al., op.cit.; A.E. Imamura, op.cit., s. 77.

110 Por. A. Fogel, M. Kawai, [za:] F. Rothbaum, op.cit., s. 5; J. Nakazawa, D.W. Schwalb, op.cit., s. 44.

111 Por. A.E. Imamura, op.cit., s. 77; S.W. Morton, K.J. Olenik, op.cit., s. 272 .

112 S.W. Morton, K.J. Olenik, op.cit.

113 Ibidem.

114 A.E. Imamura, op.cit., s. 77.

115 A. Fogel, M. Kawai, [za:] F. Rothbaum, op.cit., s. 5. 
Zaczęłam od omówienia koncepcji Ie, która w okresie Edo wykrystalizowała się w rodzinach klas wyższych, po tym okresie rozprzestrzeniła się i utrwaliła w rodzinach klas niższych, która to, najogólniej rzecz ujmując, zakładała istnienie określonego zestawu pozycji i ról, definiowała odpowiedzialność i obowiązki poszczególnych aktorów - członków Ie, a także wyznaczała im wartości, które miały być pielęgnowane przez nich, i standardy, które miały być utrzymywane, by przejść do struktury rodziny tradycyjnej, w skład której wchodzili: Kachō (głowa rodu, mąż i ojciec) wraz ze swoją żoną, dziećmi i starzejącymi się rodzicami, jego Chōnan (najstarszy syn) wraz ze swoją żoną i dziećmi, a także ich przodkowie i jeszcze nienarodzeni potomkowie. Następnie poruszyłam kwestię znaczenia małżeństwa w rodzinie tradycyjnej, będącego kluczowym rytuałem wyprowadzającym i wprowadzającym do Ie nowych członków. Wreszcie, na samym końcu, omówiłam układ pozycji i ról w rodzinie tradycyjnej, tzn. pozycję i rolę Kachō, zajmującego w nim pozycję najwyższą oraz zarządzającego Kasan i Ie, pozycję i rolę Chōnana, zajmującego w nim pozycję drugą oraz dziedziczącego po nim Kasan i wszystkie prawa i obowiązki względem Ie, oraz pozycje i role Yome (żony) i Shiūtome (matki głowy rodu, teściowej), zajmujących po nich pozycje kolejne.

\section{Bibliografia}

Adamski F., Rodzina. Wymiar społeczno-kulturowy, Kraków 2002.

Benedict R., Chryzantema i miecz. Wzory japońskiej kultury, tłum. E. Klekot, Warszawa 1999.

Cooper Masuoka E., Masuoka J., Kawamura N., Role Conflicts in the Modern Japanese Family, „Social Forces” 1962, t. 41, nr 1. 
De Mente Boyé L., The Japanese Have a Word for It. The Complete Guide to Japanese Thought and Culture, Chicago 1997. Ellington L., Japan. A Global Studies Handbook, Santa Barbara-Denver-Oxford 2002.

Fogel A., Kawai M., Hikikomori in Japanese Youth: Some Possible Pathways for Alleviating this Problem from the Perspective of Dynamic Systems Theory, [w:] Nyūyōji Hattatsu Rinshō Senta - Nenpō, Annual Report 28, marca 2006.

Frédéric L., Życie codzienne w Japonii u progu nowoczesności, tłum. E. Bąkowska, Warszawa 1988.

Gotō J.Ch., Modern Japan: A Very Short Introduction, Oxford 2009. Hall Vogel S., Japanese Society under Stress. Diagnosis and Prescription, „Asian Surve” 2012, t. 52, nr 4.

Hashimoto Kyūtaro F.X., Sushi, Sake - Sakura. O Kraju Wschodzacego Stońca i jego mieszkańcach, Poznań 2006.

Hendry J., Japończycy. Kultura i społeczeństwo, tłum. T. Tesznar, Kraków 2013.

Hendry J., Understanding Japanese Society, Second Edition, London-New York 1995.

Imamura A.E., Family Culture, [w:] The Cambridge Companion to Modern Japanese Culture, red. Y. Sugimoto, Cambridge-New York-Melbourne-Madrid-Cape Town-Singapore-Sao Paulo-Delhi 2009.

Jansen M.B., The Making of Modern Japan, Cambridge-London 2002.

Japan. Profile of a Nation, Tokyo-New York-London 1994.

Kitaōji H., The Structure of the Japanese Family, „American Anthropologist. New Series" 1971, t. 73, nr 5.

Kumagai F., Families in Japan: Beliefs and Realities, „Journal of Comparative Family Studies" 1995, t. 26, nr 1.

Martin L.G., Culter S., Mortality Decline and Japanese Family Structure, „Population and Development Review” 1983, t. 9, nr 4. 
Matsumoto D., The New Japan: Debunking Seven Cultural Stereotypes, Yarmouth 2002.

Morton S.W., Olenik K.J., Japan. Its History and Culture, Fourth Edition, New York-Chicago-San Francisco-Lisbon-London-Madrid-Mexico City-Milan-New Delhi-San Juan-Seoul-Singapore-Sydney-Toronto 2005.

Nakazawa J., Schwalb D.W. Fathering in Japan: Entering an Era of Involvement with Children, [w:] Fathers in Cultural Context, red. D.W. Schwalb, B.J. Schwalb, M.E. Lamb, New York 2013. Ogawa N., Ermisch J.F., Family Structure, Home Time Demands, and the Employment Patterns of Japanese Married Women, „Journal of Labor Economics” 1996, t. 14, nr 4.

Okazaki K., Kobiety i mężczyźni w Japonii - rozdziat stref dziatania, [w:] Być kobieta w Oriencie, red. D. Chmielowska, B. Grabowska, E. Machut-Mandecka, Warszawa 2008.

Rindfuss R.R., Bumpass L.L., Kim Choe M., Tsuya N.O., Social Networks and Family Change in Japan, „American Sociological Review" 2004 , t. 69, nr 6.

Shirai S., How Psychotherapist Can Assist People in Difficult Situations in Present Day Japanese Society. Focusing upon the Issue of Hikikomori (Social Withdrawal), „Teologia. Diakonia" 2004, t. 38.

Shwalb D.W., Nakazawa J., Yamamoto T., Hyun J.H., Fathering in Japan, China and Korea. Changing Contexts, Images and Roles, [w:] The Role of the Father in Child Development, red. M.E. Lamb, Hoboken-New Jersey 2010.

Shwalb D.W., Shwalb B.J., Fatherhood in Brazil, Bangladesh, Russia, Japan, and Australia, "Online Readings in Psychology and Culture" 2014, t. 6 (3), http://dx.doi.org/10.9707/23070919.1125 . 
Sugimoto Y., An Introduction to Japanese Society, Cambridge-New York-Melbourne-Madrid-Cape Town-Singapore-Sao Paulo 2002.

Sugimoto Y., The Cambridge Companion to Modern Japanese Culture, Cambridge-New York-Melbourne-Madrid-Cape Town-Singapore-Sao Paulo-Delhi 2009.

Tipton E.K., Modern Japan. A Social and Political History, London-New York 2002.

Yamakuse Y., Cooney M.A., Wa Spirit. Nihonjin No Kokoro (Duch japońskości) Heart \& Soul of The Japanese, Japan 2011.

\section{Abstrakt}

Przedmiotem niniejszej publikacji jest Ie, czyli model gospodarstwa domowego i japońskiej rodziny tradycyjnej, jej struktura i funkcje. Ma ona charakter przeglądowy.

Na początku pokrótce omawiam koncepcję Ie. Następnie strukturę japońskiej rodziny tradycyjnej. Dalej poruszam kwestię znaczenia małżeństwa w japońskiej rodzinie tradycyjnej. Wreszcie, na samym końcu, dość obszernie omawiam układ pozycji i ról w japońskiej rodzinie tradycyjnej, tzn. pozycję i rolę Kachō (głowy rodu, męża i ojca), pozycję i rolę Chōnana (najstarszego syna) oraz pozycje i role Yome (żony) i Shiütome (matki głowy rodu, teściowej).

Słowa kluczowe: antropologia społeczna, socjologia rodziny, struktura rodziny, funkcje rodziny, Ie, Japonia

\section{Abstract}

The subject of this publication is $I e$, the household and Japanese traditional family model, its structure and functions. It is a review publication. 
At the very beginning, I briefly discuss the concept of Ie. Then the structure of a Japanese traditional family. Then I raise the issue of the importance of marriage in a Japanese traditional family. Finally, at its very end, I quite extensively discuss the arrangement of positions and roles in the Japanese traditional family, the position and role of Kacho (head of the family, husband and father), the position and role of Chönan (eldest son) and the positions and roles of Yome (wife) and Shiūtome (mother of the head of the family, mother-in-law).

Keywords: social anthropology, sociology of family, family structure, family functions, Ie, Japan 


\title{
Andrzej Woźniak
}

emerytowany oficer Służby Więziennej

ORCID ID: https: / / orcid.org/0000-0003-1851-9743

\section{Laogai - chiński sposób na resocjalizację więźnia przez pracę}

\author{
„Porzućcie wszelką nadzieję, \\ wy, którzy tu wchodzicie"1 \\ Dante Alighieri, Boska komedia
}

\section{Wstęp}

Życie w laogai w latach 50. i 60. opisane zostały przez Harry'ego Wu w książkach Laogai oraz Troublemaker (Intrygant). Autor spędził w laogai niemal całe swoje dorosłe życie, od czasów, gdy jako młody student zaczął krytykować władzę 2 . Podobny obraz kreśli dostępna w Polsce publikacja Gao Ertai W poszukiwaniu ojczyzny. Wspomnienia z chińskiego obozu pracy ${ }^{3}$, w której to młody chiński intelektualista napisał traktat $O$ pięknie. Teoretyczne rozważania przerodziły się w swobodną ekspresję piękna, ono zaś - w symbol wolności. I tak oto piękno stało się polityczne. Esej powstał w 1957 r., w okresie złagodzonej cenzury. Ta krótkotrwała odwilż była jednak pozorna. Nieduży tekst wystarczyłl, by jego autora uznać za "prawicowy element” i skazać na zesłanie do obozu pracy na pustyni Gobi. W ten sposób

\footnotetext{
1 Dante Alighieri, Boska Komedia, tłum. A. Świderska, Kęty 2006.

2 Laogai, Wikipedia, https://pl.wikipedia.org/wiki/Laogai [dostęp: 30.01.2019].

3 G. Ertai, W poszukiwaniu ojczyzny. Wspomnienia z chińskiego obozu pracy, Wołowiec 2012.
} 
partia reedukowała niepokornych poprzez pracę. Nieodłącznym elementem tej reedukacji były: głód, mordercza praca, odarcie z woli i godności - słynny aktor kradł koledze kawałek chleba, wielki muzyk bezwstydnie żebrał o jedzenie, a uczony, który miał na koncie dwa zagraniczne doktoraty, bił się z innymi, żeby wyskrobać kadź po zupie itp. Upokarzanie siebie i innych, donosicielstwo, zobojętnienie stały się codziennością, a jedyną siłą napędową była myśl o podłym posiłku.

\section{Czy chińskie laogai może resocjalizować skazanego?}

Według Harry'ego Wu: „Laogai to obozy [...] utworzone w Chinach przez Mao, na wzór sowieckich obozów »reedukacji przez pracę«. Gułag w Rosji i laogai w Chinach miały te same cele: utrzymanie machiny terroru, pranie mózgów uwięzionych oraz dostarczanie nieograniczonych zasobów darmowej siły roboczej" ". Jest mało prawdopodobne, aby rząd chiński przedstawił chociażby zasadnicze szczegóły, dotyczące działania i pensjonariuszy swoich więzień, które uznaje za ściśle strzeżone tajemnice państwowe. System karny powinien służyć jako narzędzie sprawiedliwości ${ }^{5}$, realizujący swoje zadania poprzez zatrzymywanie, osądzanie, karanie oraz resocjalizację przestępców. Funkcja laogai w Chinach daleko

4 Laogai - obozy koncentracyjne - Rozmowa z prof. Harrym Wu, [w:] Made in China, „Polonia Christiana” 2011, nr 23.

5 W Unii Europejskiej trwa proces tworzenia wspólnej przestrzeni sprawiedliwości. Jest on oparty na trzech zasadach: powszechnego dostępu do wymiaru sprawiedliwości, budowy spójności tej przestrzeni, a także zwiększaniu partycypacji społecznej. Postulaty te są definiowane z punktu widzenia obywatela, który w ten sposób stawiany jest w centrum przestrzeni sprawiedliwości. Tym samym gwarancyjna rola państwa, zapewniająca ochronę i poszanowanie praw obywatela staje się priorytetem dla rozwoju i modernizacji przestrzeni sprawiedliwości; Por. M. Biernacki, A. Seremet, Strategia modernizacji przestrzeni sprawiedliwości w Polsce na lata 2014-2020, Warszawa 2014; B. Hołyst, Kryminologia, Warszawa 2016. 
wykraczała poza ww. standardy, dalece nie spełniając swoich zadań, zachodnich standardów sprawiedliwości ${ }^{6}$.

Obowiązujący system prawny w Chinach przez lata wykorzystywany był przez partię komunistyczną, głównie jako narzędzie, dzięki któremu - w myśl idei marksistowsko-leninowskiej - można było utrzymywać panowanie nad ludźmi. W ciągu swoich rządów partia wykorzystywała laogai do masowego prześladowania i zastraszania dużej grupy Chińczyków, którzy przez to nie stanowili zagrożenia dla swoich współobywateli.

Po zwycięstwie komunistycznej rewolucji - Komunistyczna Partia Chin (dalej: KPCh) i jej przywódca (w latach 1949-1976) Mao Zedong7 nadzorował tworzenie laogai, przy aktywnej pomocy sowieckich ekspertów, na wzór ich gułagów. W miarę rozwoju systemu w latach 50 . Mao opierał się w dużej mierze na laogai, aby móc trwale umacniać władzę, poprzez więzienie w niej wielu zwolenników Kuomintangu i członków burżu-

6 Por. H. Wu, The Chinese Laogai, https://www.linkedin.com/in/harry-wu-8baa833?trk=pub-pbmap; http://www.thegulag.org/content/chinese-laogai [dostęp: 30.01.2019].

7 Por. J. Legrand (red.), Mao Zedong, tłum. z fr. i adapt. ASSIMIL Polska, Warszawa 2000.

8 Kuomintang, Guomindang, chińska partia polityczna, założona w 1912 r. przez Sun Yat-sena; początkowo partia liberalno-demokratyczna. W latach 1922-1923 pod wpływem bolszewików Kuomintang zradykalizował swój program, stając się partią rewolucyjno-demokratyczną; w okresie 1924-1927 współpracował z KPCh; po śmierci Sun Yat-sena (w 1925 r.) nowy przywódca Kuomintangu, Chiang Kai-shek, zerwał współpracę z komunistami. Do 1937 r. trwała wojna domowa między Kuomintangem a KPCh, zawieszona z powodu inwazji japońskiej na Chiny; w 1946 r. walkę wznowiono. W 1949 r., po zwycięstwie komunistów, kuomintangowskie władze Republiki Chińskiej i wierne im oddziały wojskowe schroniły się na Tajwanie. Do śmierci Chiang Kai-sheka (1975) rządy Kuomintangu na wyspie miały charakter totalitarny; dopiero kolejni przywódcy Chiang Ching-kuo (do 1988 r.) i Lee Teng-hui (do 2000 r.) wprowadzili normy demokratyczne (w zachodnim rozumieniu) w życiu politycznym Tajwanu. Pod rządami Kuomintangu Tajwan stał się jednym z najszybciej rozwijających się gospodarczo państw świata, Kuomintang, Internetowa Encyklopedia PWN, https:// encyklopedia.pwn.pl/haslo/Kuomintang;3929083.html [dostęp: 30.01.2019]. 
azji, jak również członków partii, których skazywano za odejście od „przewodniej linii partii”. Praktyki takie zakończyły się w momencie, gdy Deng Xiaoping ${ }^{9}$ doszedł do władzy. Niestety zarówno on, jak i jego następcy nadal tłumili niepoprawności polityczne czy to w odosobnionych incydentach, czy też na większą skalę, tak jak miało to miejsce w przypadku z represjami dotyczącymi ruchu na rzecz muru demokratycznego w 1979 r. i demonstracjami na placu Tiananmen w 1989 r.

Art. 35 i 36 Konstytucji Chińskiej Republiki Ludowej ${ }^{10}$ z 1982 r. chronią wolności obywatelskie, ale niestety państwo konsekwentnie uchwala stosowne ustawy, które niszczą te zabezpieczenia, aby do końca nie stracić kontroli nad społeczeństwem. Chiny podpisały (nie do końca ratyfikując) Międzynarodowy Pakt Praw Obywatelskich i Politycznych, który również chroni wolności obywatelskie. Podobnie jak dysydenci w czasach Mao Zedonga zostali oskarżani o „zbrodnie kontrrewolucyjne” lub „antysocjalistyczne”, w dzisiejszych czasach oskarżani są o „podżeganie do obalenia władzy państwowej” lub „ujawnienie tajemnic państwowych”. Prawo z zakresu bezpieczeństwa jest na tyle niejasne, że partia może skutecznie jego używać przeciwko każdemu, kto stanowi zagrożenie dla rządu lub nawet zagraża jej wizerunkowi. W rezultacie laogai

9 Deng Xiaoping - w latach 1978-1989 faktyczny przywódca Chińskiej Republiki Ludowej, inicjator reform społeczno-gospodarczych oraz otwarcia Chin na świat, jeden z najważniejszych polityków w XX-wiecznej historii Chin. Por. W.S. Morton, C.M. Lewis, Chiny: historia i kultura, tłum. B.S. Zemanek, Kraków 2007.

10 Konstytucja Chińskiej Republiki Ludowej (chin. upr. 中华人民共和 国宪法, pinyin: Zhōnghuá Rénmín Gònghéguó Xiànfă) - podstawa i najwyższy akt prawny systemu prawnego Chińskiej Republiki Ludowej. Obecnie obowiązująca wersja konstytucji została uchwalona przez Ogólnochińskie Zgromadzenie Przedstawicieli Ludowych 4 grudnia 1982 r. Uzupełniają ją cztery nowelizacje z 12 kwietnia 1988 r., 29 marca 1993 r., 15 marca 1999 r. oraz 14 marca 2004 r.; por. Konstytucja Chińskiej Republiki Ludowej, tłum. Wu Lan, M. Dargas, Gdańsk 2012; J. Rowiński, W. Jakóbiec, System konstytucyjny Chińskiej Republiki Ludowej, Warszawa 2006. 
zostaje wypełnione nie tylko zwykłymi przestępcami, ale także dziennikarzami, autorami, cyber-dysydentami, członkami ośmiu chińskich partii demokratycznych, działaczami interesu publicznego, prawnikami zajmującymi się prawami człowieka, przywódcami podziemnego „kościoła domowego”, praktykującymi Falun Gong, niezadowolonymi członkami chińskich uciskanych mniejszości etnicznych, zwłaszcza Ujgurów i Tybetańczyków itp. ${ }^{11}$

Więźniowie w laogai byli przez dziesięciolecia ofiarami chińskiego reżimu, który to do końca nie szanował rządów prawa. Dochodziło do tego, we wczesnych latach rządów komunistycznych, że ludzie byli skazywani bez procesu sądowego. Obecnie, pomimo zbudowania bardziej stabilnego systemu prawnego, KPCh wciąż sprawuje kontrolę nad sądami. Bywa, że podejrzani często nie posiadają dostatecznego dostępu do pomocy prawnej, co skutkuje brakiem możliwości pełnej obrony, a wina, a nie niewinność, jest domniemana przed sądem ${ }^{12}$.

Co więcej, obecne chińskie prawo, w pewnych okolicznościach, zezwala policji na arbitralne zatrzymywanie podejrzanych przez dłuższy czas. Jedną z takich form zatrzymania jest osławiona laojiao (reedukacja przez pracę) - środek administracyjny, który pozwala policji na zatrzymanie podejrzanego bez procesu - na okres do trzech lat.

Likwidacja obozów pracy, zapowiadana przez Chiny w połowie listopada 2013 r., stała się w dużej mierze działaniem pozornym, podczas gdy „reedukacja przez pracę” nadal funkcjonuje, np. pod postacią „obozów rehabilitacyjnych dla narkomanów” informuje Amnesty International ${ }^{13}$. Laojiao umożliwia rządowi

11 H. Wu, The Chinese Laogai..., op.cit.

12 Ibidem.

13 Amnesty International, Reedukacja przez prace w ChRL funkcjonuje pod inna postacia, https://wiadomosci.wp.pl/amnesty-international-reedukacja-przez-prace-w-chrl-funkcjonuje-pod-inna-postacia-60789895 
łatwe oczyszczanie ulic z niechcianych ludzi, w tym pracowników poszukujących pracy, włóczęgów i dysydentów, jak miało to miejsce w przypadku Pekinu podczas Igrzysk Olimpijskich w 2008 r. Chińskie władze postawiły na oczyszczenie kulturalne i przyspieszoną sinizację (proces przyswajania lub narzucania języka lub kultury chińskiej) muzułmańskiej ludności. W 2016 r. młodych muzułmanów zaczęto izolować w obozach reedukacji, w których więźniowie zmuszani są do składania samokrytyki, publicznego odcinania się od wiary muzułmańskiej, wyrażania wdzięczności partii komunistycznej itp. ${ }^{14}$ Więźniowie, którzy zostali skazani i odbyli wyroki w laogai, mogą zostać zmuszeni do przyjęcia „pracy” w tych samych obozach pracy, w których zostali wcześniej uwięzieni lub w pobliskiej fabryce, jeśli zostaną uznani za niewystarczająco zresocjalizowanych. Praktyka taka, znana w języku chińskim jako jiuye (przymusowe pośrednictwo pracy), zasadniczo wydłuża wyrok więźnia (resocjalizację) na czas praktycznie uznaniowy ${ }^{15}$. Praktyki takie wyraźnie naruszają międzynarodowe standardy prawne, dotyczące należytego procesu. Niezależnie od kategorii uwięzienia lub sposobu, w jaki wszyscy tam się znaleźli, więźniowie w systemie laogai podlegają dwóm elementom resocjalizacji (odróżniających je od większości systemów karnych innych państw): reformie myśli i pracy przymusowej ${ }^{16}$.

„Reforma myśli” jest być może jednym z najbardziej unikalnych elementów systemu wychowawczego (resocjalizującego) laogai. Większość znanych instytucji karnych, w tym rosyjski gułag, nigdy nie włączyło reformy myśli do resocjalizacji więź-

68742017a [dostęp: 30.01.2019].

14 M. Kruczkowska, W Chinach trwa największe pranie mózgów na świecie - milion ludzi w obozach reedukacyjnych, „Wyborcza.pl”, 18.05.2018.

15 H. Wu, Laogai - chiński gutag, Nowy Jork 1992, https://doi.org/10. 4324/9780429499401, [dostęp: 30.01.2019].

16 Idem, The Chinese Laogai..., op.cit. 
niów, a przynajmniej nie kładły na nią tak wielkiego nacisku, jak to miało miejsce w niedalekiej przeszłości w Chinach $^{17}$.

Korzenie chińskiego ruchu reform myślowych sięgają początków lat 50. XX stulecia, kiedy to premier Zhou Enlai (chiński polityk i wojskowy, pierwszy premier Chińskiej Republiki Ludowej od momentu jej powstania w 1949 r.) poinformował studentów i wykładowców w chińskich uczelniach, że reforma jest niezbędna w takim kierunku i kształcie, aby intelektualiści mogli przystosować się do nowego socjalistycznego społeczeństwa. „Kontrrewolucjoniści”"18 i inne „wrogie elementy" wymagali reformy myślenia. Pod rządami Mao Zedonga przekładało się to na wymuszone wyznania, niekończące się ustne i pisemne samokrytyki oraz tzw. sesje walki, w których więźniowie byli zmuszani do krytykowania i wzajemnego się upokarzania $^{19}$.

Obecnie, gdy wspólne intensywne sesje myślowe z czasów maoizmu nie są już stosowane, wielu więźniów wciąż jest zmuszonych do wyznawania swoich zbrodni, odrzucania swoich przekonań religijnych i poglądów politycznych oraz uczestniczenia w specjalnych zajęciach z reedukacji. Proces ten może pociągać za sobą presję rówieśniczą, poniżanie, fizyczne znęcanie się przez współwięźniów, a także wymyślne tortury z rąk personelu więziennego. Przymusowa praca zbiorowa nadal jest uważana za fundamentalny sposób reformy myślenia więź-

17 Ibidem.

18 Według Kodeksu karnego z 1997 r. zbrodnia „kontrrewolucji” zdefiniowana jest jako wszelkie działanie „popełniane w celu obalenia politycznej władzy dyktatury proletariatu i ustroju socjalistycznego"; Kodeks karny Chińskiej Republiki Ludowej z dnia 1 września 1997 r., tłum. ang. Criminal Law of the People's Republic of China, Law Press China 2002; por. A.E. Pływaczewska, Kary główne w kodeksie karnym Chińskiej Republiki Ludowej, „Prokuratura i Prawo” 2008, nr 6, s. 128-142.

19 H. Wu, The Chinese Laogai..., op.cit. 
niów, a co za tym idzie - ich resocjalizacji ${ }^{20}$.

Chińska Partia Komunistyczna postrzega pracę przymusową nie tylko jako istotne narzędzie reformatorskie (wychowujące, socjalizujące, resocjalizujące), ale także jako ważne źródło wzrostu gospodarczego kraju, działające na rzecz wspierania gospodarki narodowej. Wkrótce po objęciu sterów rządzenia w Chińskiej Republice Ludowej Mao Zedong tworzy laogai, widząc w skazanym cenne i niewykorzystane zasoby pracy. Podobnie jak setki tysięcy lat temu wykorzystano przymusową pracą wiele osób do budowy Wielkiego Muru, więźniowie laogai zostali wykorzystani do przeprowadzenia wielu ważnych, publicznych projektów, poczynając w późnych latach pięćdziesiątych XX w. od Wielkiego Skoku ${ }^{21}$. Więźniowie w wielu obozach pracy zmuszani byli w budownictwie, rolnictwie, górnictwie itp. do wytwarzania, montażu lub w inny sposób przetwarzania produktów, sprzedawanych odbiorcom na całym świecie. Bez zapłaty i wystarczającej ilości żywności więźniowie zmuszani byli do wielogodzinnej pracy w bardzo ciężkich warunkach, bez właściwego sprzętu, często ze szkodą dla własnego zdrowia i bezpieczeństwa. Skazani - zgodnie z prawem mogli być bici i torturowani ${ }^{22}$. Każdy, kto dostawał się w ręce przedstawicieli władzy, bez względu na to czy był podejrzany, czy nie o popełnienie przestępstwa, mógł zostać poddany torturom. Najbardziej zagrożeni byli ludzie biedni. Tortury były powszechnie stosowaną metodą zmuszania podejrzanych do przyznania się do winy, a do tego sprawcy tortur nie ponosili odpowiedzialności za swoje czyny.

20 Ibidem.

21 Wielki Skok miał przynieść powszechny dobrobyt, a doprowadził do największej klęski głodu w historii ludzkości. Koszmar tamtych lat opisuje F. Dikötter, Wielki głód. Tragiczne skutki polityki Mao 1958-1962, Wołowiec 2013.

22 H. Wu, The Chinese Laogai..., op.cit. 
Ekonomiczny wyzysk więźniów laogai okazał się niezwykle skutecznym środkiem generowania zysków i uzyskiwania dochodów dla administratorów procederu. Olbrzymie zyski, wynikające z darmowej pracy, zachęcały do ciągłego poszerzania działalności gospodarczej laogai. Praca w tych ośrodkach była przez chińskie władze systematycznie monitorowana, a dla tych, których wyniki pracy kształtowały się poniżej ustalonych norm, standardów czekały procedury "naprawcze" (swoista dodatkowa resocjalizacja) ${ }^{23}$.

Dla wielu więźniów reforma myśli i przymusowa praca to dopiero początek okrucieństwa, z którym zmuszeni byli się mierzyć, do pozbawienie życia włącznie. Świat dowiedział się w latach 90., że Chiny znalazły nowy sposób wykorzystania więźniów, nawet po ich śmierci. Tajne dochodzenia ujawniły, że chińskie szpitale „odzyskiwały” organy pozbawianych życia więźniów. Obecnie w Chinach zaprzestano tych praktyk (z wyjątkiem ofiarowania organów do przeszczepu dla najbliższym członkom rodziny) ${ }^{24}$.

\section{Zakończenie}

Chińskie prawo od dziesięcioleci dopuszczało arbitralne formy sprawowania władzy. Bezlitośnie było tłumione wyznawanie poglądów sprzecznych z oficjalnie obowiązującymi lub jakakolwiek działalność powszechnie odbierana, jako zagrożenie dla istniejącego porządku politycznego. Tysiące politycznych oponentów, członków grup religijnych i etnicznych, obrońców praw człowieka przetrzymywanych było w więzieniach (laogai), często za pokojowe wyrażanie poglądów. Setki tysięcy ludzi przetrzymywano w obozach pracy i aresztach bez for-

$\begin{array}{ll}23 & \text { Ibidem. } \\ 24 & \text { Ibidem. }\end{array}$ 
malnego postawienia zarzutów, a wiele osób umierało w wyniku tortur. Kara śmierci, powszechnie i arbitralnie stosowana, służyła zastraszeniu ludności.

Fundamentalnymi elementami systemu penitencjarnego w Chinach była przymusowa praca oraz „przyznanie się do winy”. Zmuszanie do jednego bądź drugiego niemal zawsze prowadziło do znęcania się nad więźniami. Sprawcami tortur byli najczęściej „zaufani” - więźniowie, którym władze więzienne powierzała nadzór nad pozostałymi. Znamiennymi słowami podzielił się Lu Xun (chiński pisarz uznawany za najwybitniejszego chińskiego autora XX w.): „Rozpacz jest równie daremna jak nadzieja"25.

Gao Ertai w swej publikacji tak opisuje jedną z codziennych scen w laogai: „Ledwie wypowiedział rozkaz, a już rzuciło się ku Shangguanowi kilku mężczyzn z trzeciej brygady, którzy obalili go na kolana. Inni pobiegli po sznur, z trudem łapali oddech, tak bardzo się śpieszyli. Wykręcili mu ręce do tyłu, związali je. Plecy przywiązali na krzyż i zacisnęli węzeł na ramionach tak mocno, że zaczął się wrzynać w ciało. Shangguan wydał z siebie nieludzki odgłos, niczym świnia prowadzona na rzeź" ${ }^{26}$.

„Dzieląc ludzi na różne klasy ze względu na ich status, przy pomocy pracy przymusowej i tak zwanej «reformy myśli» laogai niszczy fizycznie, psychicznie i duchowo owych »wrogów klasowych « - posiadaczy ziemskich, bogatych chłopów, elementy burżuazyjne, antysocjalistyczne i kontrrewolucyjne. Laogai, ważnego czynnika totalitarnych rządów władz komunistycznych, nie można porównywać do normalnych więzień w normalnych krajach [...]”27.

Chiński rząd przez lata usilnie bronił systemu laogai przed światową krytyką, twierdząc, że obozy pracy tworzą normalny,

25 G. Ertai, W poszukiwaniu ojczyzny..., op.cit., s. 48.

26 Ibidem, s. 99.

27 H. Wu, Dlaczego jesteśmy przeciw laogai?, 28 kwietnia 2016, https:// www.hfhr.org.pl/tybet/?p=2833 [dostęp: 30.01.2019]. 
a nawet więcej - modelowy system więzienny, nieróżniący się niczym od systemów penitencjarnych w jakimkolwiek innym państwa. Oficjalne stanowisko chińskich władz stwierdzało, że: „System Laogai w naszym kraju stanowi ważną część systemu bezpieczeństwa publicznego i jest jednym z narzędzi dyktatury proletariatu; jego celem jest ukaranie i zreformowanie wszystkich kontrrewolucjonistów i innych kryminalistów, a przebywa w nich ok. 160 tys. osób”28.

Chcąc być państwem liczącym się na światowej arenie międzynarodowej, Chiny stopniowo dostosowują się do kanonów Zachodu. Implementacja nowych rozwiązań do praktyki stosowania prawa zgodnego z zachodnim systemem zajmie jeszcze wiele lat, jednak pozytywne zmiany - aczkolwiek niezauważalne dla przeciętnego obserwatora - sukcesywnie się dokonują ${ }^{29}$.

W obliczu narastającej krytyki laogai, Chiny odpowiedziały pozytywnymi zmianami. Oficjalnie rząd chiński uznaje uniwersalizm praw człowieka, jednocześnie wielokrotnie stwierdzając, że państwa powinny posiadać prawo do wcielania w życie praw człowieka, w zgodzie ze specyficzną kulturą, historią i sytuacją polityczną. Od 1994 r. zaprzestano używania słowa "laogai”, a zamiast tego zaczęto odnosić się do systemu jako „jianyu”, co oznacza „więzienie”. Dopiero po tym jak słowo „gułag" stało się dobrze znane, przede wszystkim dzięki staraniom nieżyjącego już Aleksandra Sołżenicyna ${ }^{30}$, wywarto nacisk, aby skończył się rosyjski system. W tej sytuacji zawsze jest nadzieja, że to samo stanie się z laogai, a słowo w tytule artykułu „resocjalizacja” stanie się kiedyś w Chinach w 100\% prawdziwe.

28 Z dokumentu Komunistycznej Partii Chin pt. Naprawa przez prace (Pekin 1985), za: Wikipedia, https://pl.wikipedia.org/wiki/Laogai [dostęp: 30.01.2019].

29 Por. A.E. Pływaczewska, Kary główne..., op.cit., s. 142.

30 A. Sołżenicyn, Archipelag GUŁag 1918-1956, tłum. J. Pomianowski (Michał Kaniowski), Poznań 2008. 
Z perspektywy europejskiej Chiny z roku na rok nabierają znaczenia, a kształtowanie relacji z Państwem Środka staje się jednym z najistotniejszych wyzwań, przed jakimi stoi Unia Europejska na arenie międzynarodowej. Niewątpliwie cały czas najważniejszym celem polityki unijnej wobec Chin jest włączenie Pekinu w proces współpracy na arenie międzynarodowej, zwiększenie zaangażowania i stopnia odpowiedzialności Chin za kwestie istotne dla społeczności międzynarodowej.

\section{Bibliografia}

\section{Literatura cytowana}

Biernacki M., Seremet A., Strategia modernizacji przestrzeni sprawiedliwości w Polsce na lata 2014-2020, Warszawa 2014.

Dante Alighieri, Boska Komedia, tłum. A. Świderska, Kęty 2006.

Dikötter F., Wielki gtód. Tragiczne skutki polityki Mao 1958-1962, Wołowiec 2013.

Ertai G., W poszukiwaniu ojczyzny. Wspomnienia z chińskiego obozu pracy, Wołowiec 2012.

Hołyst B., Kryminologia, Warszawa 2016.

Kruczkowska M., W Chinach trwa największe pranie mózgów na świecie - milion ludzi w obozach reedukacyjnych, „Wyborcza.pl", 18.05.2018.

Laogai - obozy koncentracyjne - Rozmowa z prof. Harrym Wu, [w:] „Made in China”, „Polonia Christiana” 2011, nr 23.

Legrand J. (red.), Mao Zedong, tłum. z fr. i adapt. ASSIMIL Polska, Warszawa 2000.

Morton W.S., Lewis C.M., Chiny: historia i kultura, tłum. B.S. Zemanek, Kraków 2007.

Pływaczewska A.E., Kary główne w kodeksie karnym Chińskiej 
Republiki Ludowej, „Prokuratura i Prawo” 2008, nr 6. Rowiński J., Jakóbiec W., System konstytucyjny Chińskiej Republiki Ludowej, Warszawa 2006.

Sołżenicyn A., Archipelag GUŁag 1918-1956, tłum. J. Pomianowski (Michał Kaniowski), Poznań 2008.

\section{Akty prawne}

Kodeks karny Chińskiej Republiki Ludowej z dnia 1 września 1997 r., tłum. ang. Criminal Law of the People's Republic of China, Law Press China 2002.

Konstytucja Chińskiej Republiki Ludowej, tłum. z jęz. chiń. Wu Lan, M. Dargas, Gdańsk 2012.

\section{Źródła internetowe}

Amnesty International. Raport "Chiny - Nikt nie jest bezpieczny!", http://niniwa22.cba.pl/CHINY.HTM.

Amnesty International, Reedukacja przez prace w ChRL funkcjonuje pod inna postacia, https://wiadomosci.wp.pl/amnesty-international-reedukacja-przez-prace-w-chrl-funkcjonuje-pod-inna-postacia-6078989568742017a.

Internetowa Encyklopedia PWN, https://encyklopedia.pwn.pl/. Laogai Research Foundation, https://en.wikipedia.org/wiki/ Laogai_Research_Foundation.

Oxford English Dictionary, https://en.oxforddictionaries.com/ definition/laogai.

Wu H., Dlaczego jesteśmy przeciw laogai?, 28.04.2016, https:// www.hfhr.org.pl/tybet/?p=2833.

Wu H., Laogai - chiński gułag, Nowy Jork 1992, https://doi. org/10.4324/9780429499401.

Wu H., The Chinese Laogai, https://www.linkedin.com/in/harry-wu-8baa833?trk=pub-pbmap; w kontekście: http://www. thegulag.org/content/chinese-laogai.

$\mathrm{Z}$ dokumentu Komunistycznej Partii Chin pt. Naprawa przez 
pracę (Pekin 1985), za: Wikipedia, https://pl.wikipedia.org/ wiki/Laogai.

\begin{abstract}
Abstrakt
Laogai - (chiń: 勞改; pinyin: láogăi) - skrót od Laodong Gaizao (劳动改 造), hasła określające chiński wymiar sprawiedliwości, oznaczające naprawę człowieka przez pracę, a odnoszące się do pracy więźniów w Chińskiej Republice Ludowej. Na wzorowanych na sowieckim Gułagu obozach pracy w 2007 r. przebywało w laogai ok. 6,8 mln osób. Według informacji Laogai Research Foundation ${ }^{31}$ do końca 2010 r. funkcjonowało 909 laogai, w których od 1949 r. uwięziono w sumie ok. 40-50 mln Chińczyków.
\end{abstract}

Słowa kluczowe: laogai, praca, Chiny, obóz, gułag, resocjalizacja, człowiek

\begin{abstract}
Laogai - defines the Chinese judicial system, meaning repair by work. It refers to the work of prisoners in the People's Republic of China. In the 1045 prison camps modeled on the Soviet Gulag, there are about 6.8 million people (as of 2007). The Laogai Research Foundation estimates that until 2010 there were around 900 working laogai, and from 1949, 40-50 million Chinese have been imprisoned there.
\end{abstract}

Keywords: laogai, work, China, camp, gulag, resocialization, man

31 Laogai Research Foundation jest organizacją pozarządową zajmującą się prawami człowieka, zlokalizowaną w Waszyngtonie. Misją fundacji jest gromadzenie informacji i podnoszenie świadomości publicznej na temat rozległego systemu obozów pracy przymusowej w Laogai - China; Laogai Research Foundation, https://en.wikipedia.org/wiki/Laogai_Research_Foundation [dostęp: 30.01.2019]. 


\section{Dorota Kamińska-Jones}

Uniwersytet Mikołaja Kopernilka w Toruniu

ORCID ID: https://orcid.org/0000-0002-2652-0966

\section{Agnieszka S. Staszczyk}

Uniwersytet Jagielloński w Krakowie

ORCID ID: https://orcid.org/0000-0002-5223-6969

\section{Świątynia jako nośnik nacjonalistycznych treści - wizerunki bohaterów narodowych w indyjskiej architekturze sakralnej z I pol. XX w.}

Pierwsza połowa XX w. to w Indiach czas szczególny nie tylko ze względu na starania o własne, niepodległe państwo, ale także próbę budowania wspólnej, narodowej tradycji i tożsamości obywateli nowego państwa. Zabiegi te widoczne były m.in. w różnych sferach kultury, zaś w warstwie wizualnej, w przestrzeni publicznej, idealnym nośnikiem treści narodowych okazały się świątynie. Znalazły tam swoje miejsce kluczowe postacie Tradycji: wielcy nauczyciele, przewodnicy duchowi, asceci, ale także bohaterowie historyczni, którzy w przeszłości wsławili się walką z obcym najeźdźcą. Głównie podkreślano zasługi tych występujących przeciw władcom muzułmańskim oraz imperium brytyjskiemu, nadając im bardzo często określenie: „obrońcy aryjskiej

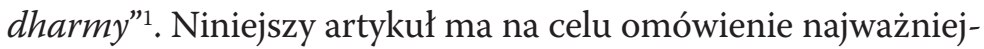
szych wizerunków bohaterów narodowych pojawiających się w sakralnym kontekście, z odniesieniem do funkcji ikonografii narodowej w nowym społeczeństwie indyjskim.

1 Terminy przytaczane z języków indyjskich zapisujemy kursywą w spolszczeniu. 
Obiektem badań stały się świątynie fundowane przez rodzinę Birlów. Jak wynika z analizy tych obiektów, których powstawanie umiejscowić należy głównie w latach 30., 40. i na początku lat 50. XX w., w koncepcji świątyni narodowej (a do tej kategorii właśnie zaliczyć należy przebadane miejsca kultu) niezwykle istotnym dla twórców było opracowanie stosownej dekoracji, której przekaz wyraźnie wzmacniałby hinduską tożsamość. Zatem, zarówno z tradycji religijnej czy literackiej, jak i z dziejów Indii, wybrane zostały odpowiednie elementy, które mogłyby stworzyć spójny przekaz dotyczący przeszłości, znaczenia i miejsca najwyższej wartości hinduskiej i etosu aryjskiego, wprost nazywanego w wielu inskrypcjach „aryjską/ hinduską dharmą"2. Ich dobór jest, co warto także zaznaczyć, często objaśniany w samych świątyniach, na specjalnych tablicach zawierających wyłącznie inskrypcje ${ }^{3}$. Arjadharmi to wy-

2 Dharma: termin ten jest jednym z najbardziej pojemnych i trudno przetłumaczalnych indyjskich pojęć. Może odnosić się do sposobu postępowania i wyjaśniać dlaczego należy go wcielać w życie. Może też odnosić się do prawa, w kontekście stosownego zachowania. W ujęciu normatywnym jest obowiązkiem albo ścieżką, którą należy obrać i mocno wiąże się ze schematem warna-aśrama-dharma. Funkcjonuje zatem (obok artha, kama i moksza) jako jeden z czterech celów w życiu człowieka. W przebadanych świątyniach termin arja-dharma używany jest m.in. dla sankcjonowania i włączania w hinduską tradycję wszystkich indyjskich religii, które mogłyby wzmocnić główny nurt tradycji, a także wesprzeć budowanie wspólnoty (nowego narodu i państwa). Charakterystyczne dla tego zabiegu jest szukanie wspólnego rdzenia i wspólnych bohaterów Tradycji, głoszących uniwersalne prawdy.

3 Na przykład w Delhi, przy przejściu z części ogrodowej do świątyni, znajduje się następujący tekst w hindi i po angielsku: „In this temple Vedmantras, Upnishadas, Shlokas, Bhajans and artistic life pictures have been inserted with a view to awaken the Aryadharami Hindus to regain their ancient glory and power and there after preach the message of peace and true happiness to the whole world. We hope all Aryadharami Hindus (including Sanatanists, Aryasamajists, Buddhists, Jains, Sikhs etc.) will accede to our humble prayer". W innej wersji brzmi on tak; "All persons erecting places of public worship should likewise inscribe Vedmantras, Upnishadas, Shlokas, Bhajans and Artistic life pictures with a view to improve the religious life of the Aryadharami Hindus (including Sanatanists, Aryasamajists, Buddhists, Jains and Sikhs etc.) and to develop among them a spirit of fellow feeling 
znawcy hinduizmu, którzy jako cel nadrzędny powinni obrać przywrócenie dawnej świetności i władzy hinduskiej, ale także pracować nad poprawą swego życia religijnego budując jednocześnie wspólnotę z wyznawcami innych indyjskich dharmicznych religii (niemniej można zauważyć, że w dyskursie narodowym, inkluzywizm hinduski, jaki wprowadzono w celach zjednoczenia tradycji rodzimych, tworzony jest w zdecydowanej opozycji do islamu. Ta religia bowiem, podobnie jak chrześcijaństwo, traktowana jest jako obca, nie-indyjska).

Jednym z najlepszych przykładów przestrzeni sakralnej realizującej wspomniane wyżej założenia jest wznoszona w latach 1933-1939 świątynia Shri Lakshminarayan ${ }^{4}$ w Delhi, w zamyśle fundatorów oraz twórców - wzorcowa Hindu Rashtra Mandir. Aby w pełni przeanalizować jej przesłanie należy uwzględnić jednak nie tylko samą budowlę, ale także przylegające do niej ogromne założenie ogrodowe. Uzyskamy wówczas pełny obraz idei tworzących podstawę programu ikonograficznego, w którym znalazły się postaci bóstw i postaci z przekazów religijnych czy mitycznych - zestawione z postaciami historycznymi, kluczowymi dla rozwoju, utrzymania i obrony hinduskości. Warto zauważyć, że zabieg ten wzmacnia przesłanie, jakie wiąże się ze świątynią narodową, ale dodatkowo pełni też funkcję edukacyjną. Począwszy od starożytnych, wielkich władców, aż po maharadźów z nieodległej historii (najpóźniej rządzący to Maharadźa Ranjit Singh, zm. 1839), kolejno przywoływani są tu strażnicy odwiecznej religii (sanatan dharm), często zaangażowani bezpośrednio w walkę z obcym najeźdźcą, który zagrażał tradycji hinduskiej. Te po-

and close co-operation which may in turn lead to consolidation and mutual service".

4 Zapis nazw własnych, miejscowości, pojęć oraz imion i nazwisk postaci od okresu nowożytności, podajemy w formie najczęściej używanej w Indiach i rozpowszechnionej w anglojęzycznej literaturze przedmiotu, unikając spolszczeń. 
staci historyczne najczęściej w inskrypcjach w hindi określane są właśnie: „władcy aryjscy/hinduscy” i „obrońcy aryjscy/hinduscy". Wielokrotnie przywoływane są ich zasługi, pojawiają się odniesienia do walecznych czynów i konkretnych bitew. Przekaz zdecydowanie skupia się na dwóch elementach: po pierwsze bohaterowie ci stanowią część tradycji/przeszłości, z której Hindusi mogą być dumni; po drugie - są to postaci, dzięki którym ta tradycja przetrwała. Cała armia kszatrijów kontynuowała dzieło boga Wisznu, rozprawiając się z wrogiem tak, jak bóg czynił to z demonami zagrażającymi porządkowi hinduskiego świata. Wśród różnych historii objaśniających przyczynę pojawienia się Wisznu na ziemi występuje jeden wspólny element - bóg zstępuje, kiedy światu, ziemi, ludzkości zagraża nieszczęście, kiedy atakują demony, kiedy zagrożona jest dharma lub prawi ludzie lub gdy trzeba wspomóc innych walczących w imię porządku i prawa. Warto zauważyć, że w ikonografii Wisznu od najdawniejszych czasów mocno eksponowana jest jego pozycja króla, członka stanu wojowników i panujących (radźanja). Najstarsze rzeźby wzorowane na postaci możnego i królów wyposażone są w stosowne atrybuty, które jednoznacznie łączą się z władzą i ochroną dysk i maczuga, a także nawiązują do koncepcji ćakrawartina ${ }^{5}$. Warto wreszcie w tym miejscu zaznaczyć, że zarówno Wisznu i jego poszczególne wcielenia (przede wszystkim Rama oraz Kryszna), jak i postaci mityczne czy historyczne przywołane w dekoracjach świątyń, zostały wplecione w długie i burzliwe dzieje obrony hinduskiej dharmy, zgodnie z tym, co w swych analizach podaje S. Pollock rozważając królewskość i boskość

5 J. Gonda, Aspects of Early Vişnuism, Delhi 1993, s. 164. Jak zauważa Gonda: "There is a striking parallelism between the special emphasis laid already in Vedic texts upon Vişnu's protecting activities and his intimate relations with kinship, the first function of which is to protect the world and its inhabitants and to defend the dharma, to punish the wicked". 
Ramy czy boski status władców. Badacz powołuje się na tyleż interesujący, co znamienny fragment z Waju-purany: „każdy władca, w każdym czasie, w przeszłości i przyszłości, rodzi się z częścią Wisznu w sobie"6.

Wcielenia Wisznu wybrane do dekoracji bardzo często zajmują eksponowane miejsce, w pobliżu sanktuarium: Kryszna na globie, Paraśurama, Rama, Budda. Z całą pewnością najbardziej znaczącą jest tu postać Kryszny, przy której dodatkowo widnieje cytat z Bhagawadgity - „Dla ochrony szlachetnych, dla zniszczenia zła, aby prawo utrwalić, Ja się odradzam z wieku na wiek"7. W zależności od konieczności dziejowej bóg wciela się w różne formy i jest to bezpośrednio związane $\mathrm{z}$ obroną dharmy.

Ponadto znaczący są w tym kontekście także Paraśurama, Rama Ćandra (Rama Wspaniały) i Budda. Zgodnie z przekazami mitów puranicznych Paraśurama musiał dokonać swoistego oczyszczenia ziemi z nieprawych przedstawicieli stanu rycerskiego (kszatrija). Podobnie, u Ramy zarówno cechy, jak i jego rola od początku stawiały boga blisko stanu wojowników, czyniąc z niego wzór godny naśladowania przez wszystkich władców. Jak zauważają A. Daniélou i D. Stasik panowanie Ramy jest synonimem rządów sprawiedliwych, pokoju i dostatku, powszechnej prawości i szczęśliwości, kluczowym elementem etosu północno-indyjskiego ${ }^{8}$. Omawiając problem włączenia

6 „Every emperor, in every cosmic age both past and future, is born on earth with a portion of Vişnu within him" w: Waju-purana 57.72, za: S. Pollock, The Divine King in the Indian Epic, „Journal of the American Oriental Society" 1984, vol. 104, nr 3, s. 526. Więcej na temat boskiego charakteru władców zob. ibidem, s. 523-527.

7 4.8, polskie tłum. za: Bhagawadgita. Pieśń Czcigodnego Pana, tłum. M. Kudelska, Kraków 1995, s. 23. Bóg w funkcji strażnika dharmy przede wszystkim objawia się w trakcie nauk udzielanych Ardźunie.

8 A. Daniélou, The Myths and Gods of India, Rochester 1991, s. 173. „The expression »Rāma-rājya « (the kingdom of Rāma) is still synonymous with peace and prosperity". 
w dekorację takich postaci, jak Rama należy jednak podkreślić nie tylko to, że zgodnie $\mathrm{z}$ Tradycją $\mathrm{w}$ formie przejawionej na ziemi bóg ten przyjmuje na prośbę innych bóstw oraz wyznawców rolę strażnik dharmy, ale też zwrócić uwagę na fakt, jak szczególne staje się przywołanie tej postaci w literaturze indyjskiej przełomu XIX i XX w. oraz późniejszej. Jak zauważa D. Stasik, jest to wynik wzrostu świadomości narodowej połączonego z próbą określenia własnej tożsamości. W tym kontekście liczne odwołania do przeszłości są konieczne, a Rama jest jednym z kluczowych bohaterów hołdujących tradycyjnym wartościom, drugim z nich jest Kryszna. Promowano zatem utwory, które odwoływały się do doskonałej przeszłości, mitycznych i epickich bohaterów. Przywrócenie złotego okresu rządów dawnych prawych władców mogło się dokonać za sprawą reform społecznych i rozbudzania patriotyzmu. Tym samym Rama pełni tu rolę władcy idealnego-reformatora, jako uosobienie ideału demokracji, którą, za Gandhim, rozumie się jako władzę w rękach ludu. Walcząc z niearyjskimi, występującymi przeciw dharmie demonami, Rama zapowiada rządy szlachetnych Arjów ${ }^{9}$. Wykorzystanie postaci Ramy może być zatem traktowane jako szczególne, nie tylko ze względu na jego przynależność do grupy zstąpień Wisznu, pojawiającego się na ziemi by ochraniać dharmę, ale także, a nawet przede wszyst$\mathrm{kim}, \mathrm{z}$ racji interpretacji tej postaci $\mathrm{w}$ okresie narodowego odrodzenia.

Wśród postaci obrońców i propagatorów hinduskiej dharmy pojawiają się także „śmiertelnicy”, których zobaczyć można między innymi w Delhi. Na ścianach tamtejszej świątyni Lakshminarayan umieszczono malowidła, które ukazują ważnych aryjskich/hinduskich władców w otoczeniu dworu, w trakcie istotnych wydarzeń. Mogą oni stanowić temat lekcji historii

9 D. Stasik, The Infinite Story. The Past and Present of the Rāmāyanas in Hindi, New Delhi 2009, s. 248-254. 
oraz przywoływać złote czasy i świetność dawnych mocarstw, służą też jako wzór do naśladowania - w rzetelny sposób realizują bowiem swą dharmę kszatriji. W grupie tej znajdziemy postaci legendarne i historyczne: Manu, braci Pandawowów, Candraguptę Maurję, Aśokę, Maharadźę Raghu, Wikramaditję, Chhatrapati Shivaji, Guru Gobind Singha, Maharadźę Ranjit Singha, Tegh Bahadurę. W założeniu ogrodowym tejże świątyni wprowadzono różnorodne przedstawienia, a zatem, poza wymienionymi wyżej, odnajdziemy tu także Maharadźę Prithviraja Chauhana, Maharanę Pratapa, Maharadźę Surajmala z Bharatpuru. Ich atrybuty to broń - najczęściej pojawiają się miecze i sztylety, ale także włócznie, buławy, katary i tarcze. Poza informacjami historycznymi, które przy poszczególnych postaciach gloryfikują ich szlachetne, bohaterskie czyny, wszyscy zostali opatrzeni podpisem - „obrońca/władca aryjski (Hinduski)”10. Łączy ich to, że stworzyli, przywrócili bądź utrzymywali wielkie hinduskie państwa; walczyli z najeźdźcą - głównie władcami muzułmańskimi, podejmowali działania na rzecz chwały Indii.

Poza pomnikami całopostaciowe płaskorzeźbione wizerunki znajdują się również na słupie, który jest podpisany jako kirtistambha, a więc dosłownie „słup chwały”, monument, pomnik, objaśniany też w literaturze jako "hero stone” - kamień pamięci. Jest to obiekt nawiązujący do dawnej tradycji wznoszenia słupów upamiętniających władców i ich bohaterskie czyny, zwycięstwa czy też śmierć. Upamiętnieni zostali na nim waleczni i niezłomni, którzy od XV do XX w. ery Wikrama czynili nieustanne starania o przywrócenie i ustanowienie rządów aryjskich, a także bronili dharmy i hinduskiej dźati: Guru Gobind Singh, Maharadźa Ranjit Singh, Maharadźa Chhatrasal Bundela,

10 Powierzchnia cokołów, niekiedy dość wysokich, stała się idealnym miejscem dla inskrypcji, do wielu władców zatem przypisano także różne teksty czy to bezpośrednio się z nimi wiążące, czy też nawiązujące do sztuki rządzenia (radźaniti). 
Durgadas Rathore, Rama Raya z Widźajanagaru, Mahadaji Shinde z Gwalioru, Surajmal z Bharatpuru, Vir Banda Bairagi (Sant), Teg Bahadur, Maharana Pratap Singh, Raja Hemachandr Vanik z Delhi, Maharana Kumbha z Chittoru, Maharani Sati Padmini z Chittoru, Maharani Lakshmibai z Jhansi. Część tych postaci została także, jak wspomniano wyżej, ujęta w innych przedstawieniach w świątyni lub w założeniu ogrodowym.

Spośród bohaterów na szczególną uwagę zasługuje kilka postaci. Jednymi z nich są bracia Pandawowie, którzy ukazani zostali wielokrotnie na reliefach, malowidłach, $\mathrm{np}$. w mandapie głównej świątyni w Delhi, gdzie wraz z Draupadi otaczają Krysznę (przedstawienie pt. „Leśne wygnanie braci Pandawów”). Podobne malowidło znajdziemy w Birla Mandir w Mathurze, jest ono opatrzone cytatami z Mahabharaty dotyczącymi sztuki rządzenia i konieczności zachowania dharmy. Ich obecność można interpretować dwojako: są przykładem faktycznej realizacji przesłania Kryszny z Gity, wcielają w czyn nauki o powinnościach kszatrijów, a także są wliczeni w poczet ważnych bohaterów narodowych. Epos, który traktuje o wielkiej bitwie, przepełniony naukami na temat dharmy, prawa i polityki, jest tu oczywistą referencją.

Poza legendarnymi władcami przywoływani są starożytni władcy historyczni, np. z dynastii Maurjów - Ćandragupta Maurja (321-298 p.n.e.) i Aśoka (panował 268-232 p.n.e.). Obaj widnieją na malowidłach w głównej świątyni w Delhi oraz na pomnikach w ogrodzie. Z Ćandraguptą mocno związana jest ponadto postać Ćanakji - naczelnego ministra i nauczyciela obu cesarzy oraz wielkiego znawcy polityki królewskiej. Aśoka $\mathrm{z}$ kolei występuje też $\mathrm{w}$ roli propagatora i protektora nauki buddyjskiej. Wśród strażników dharmy jednak jest postacią stawianą w grupie wielkich władców - twórców wartej przywołania i naśladowania polityki państwowej. Buddyjska dharma/dhamma, na którą się powoływał, była przecież spo- 
sobem na rządzenie rozległym imperium oraz na zjednoczenie wielokulturowego społeczeństw ${ }^{11}$. Z tego właśnie powodu Aśoka - stawiany jako jeden z największych władców w indyjskiej przeszłości, a jednocześnie wzór do naśladowania, jest przywoływany w omawianych tu dekoracjach.

Przykładem władcy nowożytnego jest Radźa Hem (Hemu) Chandra Vanik z Delhi (1501-1556) ${ }^{12}$, który miejsce wśród bohaterów i obrońców dharmy zyskał dzięki działaniom na rzecz obrony hinduskiej tradycji. Można by je śmiało określić jako makiaweliczne, jego historia jest bowiem szczególna. Przyszedł na świat w ubogiej rodzinie, w warstwie waiśjów. Kształcił się w sanskrycie, a także języku perskim i hindustani. Pracował jako kupiec w administracji rządowej, doszedł do urzędu „Superintendent of Markets in Delhi” pod władzą Islama Shaha. Jego inteligencja, spryt oraz militarne zdolności sprawiły, że stał się z czasem zaufanym doradcą władcy. Za panowania Adil Shaha mianowany został głównym ministrem („Vakil-i-Alah”), a władca ufał mu bezgranicznie. Jego działania przede wszystkim miały się koncentrować na usunięciu władców mogolskich z Indii, po powrocie cesarza Humajuna z wygnania. Po jego śmierci Hemu walczył z mogolskimi oficerami, zdołał odbić Delhi z rąk mogolskich wodzów. Ogłosił Hindu Radź w Indiach i przyjął imię Wikramaditja.

Kolejny z bohaterów - Maharana Kumbha z Chittoru (1433-1468) wsławił się przede wszystkim wielokrotnym pokonaniem ataków dokonywanych przez muzułmańskich najeźdźców, w tym władcy Malwy, a także jako budowniczy. Wzniósł wiele fortyfikacji, w tym słynną Victory Tower (1458 r.), mającą upamiętnić jego dokonania. Postać władcy wzbudzała zachwyt

\footnotetext{
11 N. Lahiri, Ashoka in Ancient India, Cambridge 2015.

12 W informacji na słupie nad jego postacią umieszczono napis wychwalający go jako bohatera, dzięki staraniom którego udało się w Delhi przywrócić na jakiś czas hinduskie rządy.
} 
kronikarzy. James Todd nie szczędził mu pochwał ${ }^{13}$, reformatorzy społeczni i nacjonaliści wymieniali go i opisywali pośród największych wojowników Indii (między innymi Abanindranath Tagore w Raj Kahini). Niektórzy z nich poświęcali mu też całe opracowania. Jednym z nich był Har Bilas Sarda, który napisał całą książkę poświęconą Maharanie, bowiem wedle jego słów za mało dotychczas było wiarygodnych informacji na temat tego wybitnego władcy. Autor, co zaznaczył we wstępie, przebadał bardzo wiele nieznanych wcześniej źródeł, niektóre z nich miały unikatowe znaczenie ${ }^{14}$. Maharana Kumbha na obiekcie ufundowanym przez Birlów (kirtistambha w Delhi) przedstawiony jest w konwencji malarstwa miniaturowego, nawiązującego do jego imaginacyjnych porterów wykonywanych na dworze w Mewarze i podpisany mahawir („wielki bohater”).

Maharana Pratap Singh (1540-1597) uważany był za jednego z najwybitniejszych władców radźpuckich. Wsławił się przede wszystkim swoją bohaterską postawą w konfrontacji z Akbarem. Gdy mogolski władca zażądał uznania swojej zwierzchności, nieustraszony Pratap Singh odmówił i stanął do nierównej walki z siłami wroga w bitwie 18 czerwca $1576 \mathrm{r}$. Jego bohaterska postawa przemawiała niezwykle mocno do nacjonalistów indyjskich, którzy widzieli w nim uosobienie hinduskiego honoru i niezłomności. Również historycy byli niekiedy pod wielkim wrażeniem postawy nieustępliwego Maharany i w swoich opisach ulegali retoryce nacjonalistów. Pratap Singh, tak ważny historiografii narodowej, pojawia się wielokrotnie na obiektach fundowanych przez Birlów. Najwięcej jego przedstawień

13 “(...) he had triumphed over the enemies of his race, fortified his country with strongholds, embellished it with temples, and with the superstructure of her fame had laid foundation of his own", J. Tod, Annals and Antiquities of Rajasthan; Or the Central and Western Rajput States of India, t. I, red. William Crooke, London-New York, s. 338.

14 S.H. Bilas, Maharana Kumbha: Sovereign, Soldier, Scholar, Ajmer 1917, s. X. 
znajduje się w najstarszej fundacji, czyli założeniu świątynnym Lakshminarayan w Delhi. Wyobrażony jest on tam zarówno na pomniku w ogrodzie, jak i na płaskorzeźbie na kirtistambha oraz na panelu w pawilonie w ogrodzie. W inskrypcji opisano go w następujący sposób: „Władca Mewaru, obrońca hinduskiej dharmy, szczycący się swym krajem, niezłomnie pobożny, klejnot wśród bohaterów, który we własnych niezliczonych wyrzeczeniach, niezłomnej stanowczości, ogromnej tężyźnie, całe życie umiłował walkę, niejeden raz pokonał Mogołów i przywrócił honor/świetność kraju. Bohaterscy władcy radźpuccy z Mewaru - ziemi wydającej na świat bohaterów, aby bronić niepodległości i honoru swej ojczystej ziemi, nieprzerwanie 500 lat walczyli z obcymi władcami Delhi, i niezmiennie nie przyrzekli im swego poddaństwa. Maharana Pratap Singh w tych radźpuckich władców łańcuchu jest jednym z głównych ogniw"15. Na większości wyobrażeń styl nawiązuje wyraźnie do malarstwa miniaturowego, charakterystycznego dla ośrodka w Mewarze. Taki właśnie wizerunek Maharany był bardzo mocno zakorzeniony w powszechnej wyobraźni i utrwalany do tego stopnia, że nawet Raja Ravi Varma również podążał za tradycyjną konwencją ${ }^{16}$.

Maharadźa Chhatrapati Sivaji (1630-1680), twórca Imperium Marathów, stał się centralnym bohaterem dla nacjonalistów indyjskich. Był on dla nich uosobieniem idealnego króla, który dzięki swoim zabiegom - zarówno militarnym, jak i dyplomatycznym - odbił znaczne tereny spod władzy muzułmańskich władców - tak z sułtanatów, jak i Wielkich Mogołów. Był on twórcą potężnego, hinduskiego państwa, z nowoczesną strukturą militarno-administracyjną. Jego historia obrosła legendami i stała się kanwą dla dzieł historycznych oraz popularnych. Historycy i nacjonaliści prześcigali się w publikacjach

15 Wszystkie tłumaczenia z hindi w artykule - Agnieszka Staszczyk.

16 1901, Shriji Arvind Singhji Mewar, Udaipur, zob. np. R. Chawla, Raja Ravi Varma: Painter of Colonial Indian, Ahmedabad 2010, s. 127. 
na temat władcy, tworząc wizję idealnego bohatera, który stał się symbolem obrońcy dharmy hinduskiej ${ }^{17}$. Tego wielkiego władcy, wręcz symbolu walk o niepodległość, nie mogło więc zabraknąć na świątyniach Birlów. Pojawia się w dekoracjach w trzech ujęciach: na pomniku w delhijskim ogrodzie, gdzie tytułowany jest „Wybawcą aryjskiej/hinduskiej dharmy, którego wielki majestat i splendor, a także zręczność w polityce, obróciły w pył tyranię władzy Mogołów"18; na kirtistambha oraz na przedstawieniach polichromowanych lub czarno-białych w świątyniach wraz z Ramdasem. Te ostatnie opatrzone są cytatami z informacją o zacnym obowiązku przywrócenia hinduskich rządów, państwa aryjskiego, o którym poucza go guru.

Z racji włączania innych tradycji religijnych do grona aryjskiej dharmy, w świątyniach pojawiają się także postaci sikhijskich guru i wojowników. Wsławili się oni głównie walkami przeciw władcom mogolskim, lecz bronili nie tylko swojej wiary, a również hinduskiej dharmy, co skrzętnie odnotowują inskrypcje. Przykładem może tu być Tegh Bahadur (1621-1675), dziewiąty guru Sikhów, męczennik w obronie wiary, przeciwstawiający się cesarzowi Aurangzebowi i jego rozkazom przymusowych konwersji na islam ${ }^{19}$. Jego ogromną zasługą było wzięcie w obronę braminó $\mathrm{w}^{20} \mathrm{z}$ Kaszmiru, których Aurangzeb

17 Zob. np. J.L. Mankar, Life and Exploits of Shivaji. Translated into English from an Unpublished Marathi Manuscript, Bombay 1880; S.V. Reddy, Shivaji, Thana1921; J. Sarkar, Shivaji And His Times, Calcutta 1929.

18 Ponadto na cokole umieszczono też fragment poematu Bhushana wychwalającego władcę. Słowa te powtórzone są w fundacjach w Mathurze i Varanasi.

19 Por. np. S.S. Johar, Guru Tegh Bahadur. A Biography, New Delhi 1975, s. 13: „He died as people's hero, a defender of faith and a fighter against tyranny and injustice. His sacrifice at the altar of his faith »undoubtedly strengthened the resistance against the religious policy of Aurangzeb and at the same time prepared the way for the final stage in the evolution of Sikhism«. (...) His execution was universally regarded by the Hindus as a sacrifice for their faith".

20 Por. malowidła w Kurukshetrze i Varanasi ukazujące scenę rozmowy 
nakazał, pod groźbą stracenia, nawrócić na islam. Na rozkaz cesarza został pojmany i stracony w Delhi, w publicznej egzekucji, po kilku tygodniach tortur, w czasie których próbowano go jeszcze nakłonić do przejścia na islam ${ }^{21}$. Nic dziwnego zatem, że wśród postaci bohaterów i władców strzegących hinduskiej dharmy ${ }^{22}$ zajmuje miejsce szczególne, jako że „poświęcił swe życie, aby ochronić wolność religijną hindusów”23.

Rani Lakshmibai z Jhansi (1828 -1858), która zasłynęła bohaterską obroną swojego kraju przed Brytyjczykami podczas powstania sipajów w 1858 r., przypłacając to własnym życiem²4, stała się w retoryce nacjonalistów symbolem niezłomnej postawy i walki z obcym najeźdźcą. Ta wielka królowa stanęła na czele armii i bohatersko broniła swojego państwa przez siłami wroga. Wykazała się przy tym tak wielkim męstwem i odwagą, że wzbudziła podziw również i u przeciwników. Brytyjczycy nie

z braminami, która odnosi się bezpośrednio do obietnicy obrony przed przymusową konwersją. Jest to kompozycja wielopostaciowa, opatrzona inskrypcją w hindi i pańdźabi (w piśmie gurmukhi), gdzie pojawiają się tak znamienne słowa Tegha, jak: „jestem kszatrija”, „poświęcę się dla obrony dharmy, krów i braminów". W kontekście ówczesnych starań o wprowadzenie ochrony krów, a także konfliktu na linii hindusi-muzułmanie z powodu rzezi krów i innych zwierząt Tegh Bahadur musiał być zatem postrzegany jako prawdziwy bohater. Przywołanie go w takiej roli świadczy również o dużej randze ruchu ochrony krów. Ideologicznie można jej wprowadzenie rozpatrywać jako jeden z gwarantów moralności nowego państwa. Więcej zob. T. O’Toole, Secularizing the Sacred Cow. The Relationship between Religious Reform and Hindu Nationalism, [w:] Hinduism in Public and Private. Reform, Hindutva, Gender, and Sampraday, red. A. Copley, New Delhi 2003, s. 84-109.

${ }^{21}$ M.P. Kohli, Guru Tegh Bahadur, Testimony of Conscience, New Delhi 1992.

22 Na niewielkim malowidle na tablicy przy wejściu do pawilonu Gita mandir w Delhi znamienny jest tytuł, jakim opatrzono tu tego bohatera: "obrońca krów i braminów, obrońca hinduskiej dharmy".

23 N. Singh, Searches in Sikhism. Thought, Understanding, Observance, Delhi 2008, s. 130.

24 Więcej zob. np.: R. Jerosch, The Rani of Jhansi, Rebel Against Will: A Biography of the Legendary Indian Freedom Fighter in the Mutiny of 1857-1858, tłum. J.A. Turner, Delhi 2007. 
spodziewali się bowiem, że kobieta stawi im taki opór ${ }^{25}$. Wspominana była w wielu źródłach historycznych, opisach zdarzeń związanych z powstaniem sipajów, stała się też bohaterką opowiadań i poematów ${ }^{26}$. Dla hindusów była symbolem niezłomności i przykładem idealnej Aryjki. Nacjonaliści widzieli w niej ideał kobiety-wojowniczki i patriotki, z podziwiem wypowiadał się o niej też Vivekanada ${ }^{27}$. Tak ważnej postaci w indyjskim panteonie sław nie mogło zabraknąć w fundacjach Birlów. Jej wizerunek umieszczono na kirtistambha w ogrodzie w Delhi pośród innych wielkich obrońców dharmy. Co ciekawe, mimo, że źródła podają, że do walki przywdziała męski strój, ukazana jest w sari, a tylko dodatkowe elementy jak turban czy broń wskazują, że jest ona wojowniczką. Pozostaje więc nadal idealną kobietą, ale jednocześnie niezłomną heroiną, która dla kraju nie wahała się poświęcić życia.

Podsumowując można stwierdzić, że charakterystycznym elementem wspólnym tych postaci jest walka przeciwko obcym rządom, a przede wszystkim Mogołom. Wśród nich znajdziemy

25 J.W. Kaye, G.B Malleson, Kaye's and Malleson's History of the Indian mutiny of 1857-8, t. V, London 1899, s. 154-155.

26 Np. P. Cox, The Rani of Jhansi. A Historical Play in Four Acts, London 1933; M. White, Lachmi Bai Rani of Jhansi, the Jeanne d'Arc of India, New York 1901; więcej na ten temat zob. I. Sen, Inscribing the Rani of Jhansi in Colonial 'Mutiny' Fiction, „Economic and Political Weekly”, 12-18.05.2007, vol. 42, nr 19, s. 1754-1761.

27 "She was concentrated essence of all virtues. A mere woman, hardly twenty-three yet, beautiful as the rose, charming in her manners, pure of conduct, she had a power of organisation of her subjects, exhibited by very few, even among men. The flame of patriotism was always burning in her heart. And she was proud of her country's honour and pre-eminent in war! It is very rarely that a nation is so fortunate as to be able to claim such as angelic person, as a daughter and a queen (...) This our Land of the Bharatas, was fortunate, indeed, in giving birth to such a gem. It is shining brighter than fire. It is shining through the flames rising before cottage of Gangadas Bawa. But, even our glorious land could hardly have given birth to such a gem but for this glorious War of Independence!", Swami Vivekananda, The Complete Works of Swami Vivekananda, vol. 9, Calcutta 1933, s. 349. 
zarówno tych, którzy stoją w pierwszym szeregu narodowych, na wskroś hinduskich bohaterów, jak i postaci mniej znane. Jako jedną z przyczyn można uznać to, że konflikt z muzułmanami w czasie fundowania pierwszych świątyń był powszechnym, palącym problemem. Myśl przewodnią wybranych tu dekoracji świątyń stanowią odwołania do prawa, dharmy oraz polityki królewskiej, które w czasach budowania wspólnoty Hindusów i tworzenia niepodległego państwa miały szczególne znaczenie. Przesłanie zatem koncentruje się nie tylko na ważnych władcach i wydarzeniach gloryfikujących przeszłość i wzmacniających dumę narodową, ale też podkreśla znaczenie tych rządzących, których państwa obejmowały największą część ziem indyjskich. Broniący dharmy hinduskiej są tym samym jednocześnie inspiracją do walki z obcą władzą, jak i do tworzenia nowej polityki, która oparta jest na hinduskiej tradycji, prawie i polityce wielkich przywódców z przeszłości.

\section{Bibliografia}

Bhagawadgita. Pieśń Czcigodnego Pana, tłum. M. Kudelska, Kraków 1995.

Bilas S.H., Maharana Kumbha: Sovereign, Soldier, Scholar, Ajmer 1917.

Chawla R., Raja Ravi Varma: Painter of Colonial Indian, Ahmedabad 2010.

Cox P., The Rani Of Jhansi. A Historical Play in Four Acts, London 1933.

Daniélou A., The Myths and Gods of India. The Classic Work on Hindu Polytheism, Rochester 1991.

Gonda J., Aspects of Early Vişnuism, Delhi 1993.

Jerosch R., The Rani of Jhansi, Rebel Against Will: A Biography of the Legendary Indian Freedom Fighter in the Mutiny of 1857-1858, tłum. J.A. Turner, Delhi 2007. 
Kaye J.W., Malleson G.B., Kaye's and Malleson's History of the Indian Mutiny of 1857-8, t. V, London 1899.

Kohli M.P., Guru Tegh Bahadur, Testimony of Conscience, New Delhi 1992.

Mankar J.L., Life and Exploits of Shivaji. Translated into English from an Unpublished Marathi Manuscript, Bombay 1880.

Lahiri N., Ashoka in Ancient India, Cambridge 2015.

O'Toole T., Secularizing the Sacred Cow. The Relationship between Religious Reform and Hindu Nationalism, [w:] Hinduism in Public and Private. Reform, Hindutva, Gender, and Sampraday, red. A. Copley, New Delhi 2003.

Pollock S., The Divine King in the Indian Epic, "Journal of the American Oriental Society" 1984, vol. 104, nr 3.

Reddy S.V., Shivaji, Thana 1921.

Sarkar J., Shivaji And His Times, Calcutta 1929.

Sen I., Inscribing the Rani of Jhansi in Colonial 'Mutiny' Fiction, „Economic and Political Weekly”, 12-18.05.2007, vol. 42, nr 19.

Singh N., Searches in Sikhism. Thought, Understanding, Observance, Delhi 2008.

Singh J.S., Guru Tegh Bahadur. A Biography, New Delhi 1975. Stasik D., The Infinite Story. The Past and Present of the Rāmāyañas in Hindi, New Delhi 2009.

Tod J., Annals and Antiquities of Rajasthan; Or the Central and Western Rajput States of India, t. I, red. W. Crooke, London-New York.

Vivekananda Swami, The Complete Works of Swami Vivekananda, vol. 9, Calcutta 1933.

White M., Lachmi Bai Rani of Jhansi, the Jeanne d'Arc of India, New York 1901. 


\title{
Abstrakt
}

Pierwsza połowa XX w. to w Indiach czas szczególny nie tylko ze względu na starania o własne, niepodległe państwo, ale także próbę budowania wspólnej, narodowej tradycji i tożsamości obywateli tego nowego państwa. Zabiegi te widoczne były m.in. w różnych sferach kultury, zaś w warstwie wizualnej, w przestrzeni publicznej, idealnym nośnikiem treści narodowych okazały się świątynie. Znalazły tam swoje miejsce kluczowe postacie Tradycji: wielcy nauczyciele, przewodnicy duchowi, asceci, ale także bohaterowie historyczni, którzy w przeszłości wsławili się walką z obcym najeźdźcą. Głównie podkreślano zasługi tych, którzy występowali przeciw władcom muzułmańskim oraz imperium brytyjskiemu, zwąc ich „obrońcami aryjskiej dharmy”. Artykuł ma na celu omówienie najważniejszych wizerunków bohaterów narodowych pojawiających się w sakralnym kontekście, $\mathrm{z}$ odniesieniem do funkcji nowej ikonografii narodowej.

Słowa kluczowe: Birlowie, architektura indyjska, nacjonalizm indyjski, ikonografia nacjonalistyczna

\begin{abstract}
The first half of the twentieth century in India was a special time not only because of the struggle for independence, but also the attempt to build a common national tradition and identity for the citizens of this new state. These endeavours were visible, among others, in various spheres of culture, and in terms of art in the public space, temples proved to be the ideal medium of national content. The key figures of Tradition found their place there: great teachers, spiritual guides, ascetics, as well as historical heroes, who had previously won fame for their battle against an alien invader. Mainly the merits of those who had opposed Muslim rulers and the British Empire were emphasised and referred to as 'defenders of the Aryan Dharma. The article aims to discuss the most important images of national heroes appearing in a sacred context, with reference to the function of a new national iconography.
\end{abstract}

Keywords: Birlas, Indian architecture, indian nationalism, nationalistic iconography 


\section{Aleksandra Kobylańska}

Szkoła Główna Gospodarki Wiejskiej

ORCID ID: https://orcid.org/0000-0001-9006-6633

\section{Tradycyjna dieta azjatycka w kontekście uwarunkowań pedagogiki społecznej}

Europejczyk je dla zaspokojenia głodu, Azjata je, aby uzdrowić organizm

\section{Wstęp}

Według Edwarda Mazurkiewicza ${ }^{1}$ „wychowanie zdrowotne polega na kształtowaniu nawyków, służących konserwacji i doskonaleniu zdrowia, na rozwijaniu pozytywnego zainteresowania zdrowiem, w oparciu o niezbędne wiadomości i wzorce, na formowaniu postawy umożliwiającej skuteczną profilaktykę, ratownictwo, leczenie, pielęgnację i stosowanie wymogów higieny w życiu jednostki i zbiorowości ludzkiej”.

Pedagogika społeczna to subdyscyplina naukowa, dział pedagogiki zajmujący się tradycyjnie środowiskowymi uwarunkowaniami wszelkich procesów opiekuńczo-wychowawczych i rozwoju jednostki w różnych fazach życia człowieka. Ponadto do celów i zadań pedagogiki społecznej zalicza się prowadzenie działań profilaktycznych i kompensacyjnych, przygotowanie jednostki do satysfakcjonującej ją partycypacji społecznej².

1 E. Mazurkiewicz, Podstawy wychowania zdrowotnego, [w:] Higiena i ochrona zdrowia, red. Z. Brzeziński, C.W. Korczak, Warszawa 1975.

2 A. Radziewicz-Winnicki, Pedagogika społeczna, Warszawa 2008, s. 617. 
„Współcześnie w efekcie procesów demokratyzacji życia społecznego [...] kwestie kultury, problemów socjalnych, zdrowotnych i ekologicznych nabierają szczególnego znaczenia”3.

Wśród wielu czynników oddziałujących na zdrowie człowieka zasadnicze znaczenie odgrywa żywienie. Zdrowe, racjonalne żywienie jest jedną z podstawowych potrzeb człowieka i warunkiem prawidłowego rozwoju, dobrego samopoczucia oraz pełnej dyspozycji do uczenia się.

Pedagogika zdrowia stanowi teoretyczną podstawę wychowania zdrowotnego. Zasadniczym jej zadaniem jest wypracowanie formuły współdziałania pedagogiki z medycyną i w konsekwencji przekładanie kategorii medycznych na kategorie pedagogiczne. Kluczowym dla niej pojęciem jest pojęcie zdrowia. Od tego jak to pojęcie będziemy rozumieć, zależy koncepcja wychowania zdrowotnego, jego strategia i program. „Zdrowie [definicja Światowej Organizacji Zdrowia (WHO) z 1946 roku - przyp. A.K.] jest stanem pełnego, dobrego samopoczucia/dobrostanu (wellbeing) fizycznego, psychicznego i społecznego, a jednostki lub grupy muszą mieć możliwość określania i realizowania swoich dążeń, zaspokajania potrzeb, a także zmiany środowiska bądź radzenia sobie z nim. Dlatego zdrowie jest postrzegane jako zasób życiowy, a nie cel życia. Zdrowie jest pojęciem pozytywnym, obejmującym zasoby osobiste i społeczne oraz możliwości fizyczne, a nie tylko brakiem - obiektywnie istniejącej - choroby, czy niepełnosprawności”. A zatem pełne zdrowie to poczucie siły życiowej, zdolność do pokonywania przeszkód, chęć podejmowania trudów fizycznych i umysłowych.

3 A. Przecławska (red.), Pedagogika społeczna, kręgi poszukiwań, Warszawa 1996, s. 23-26.

4 Preamble to the Constitution of the World Health Organization as adopted by the International Health Conference, New York, 19 June-22 July 1946, http://www.who.int/en/ [dostęp: 17.04.2019]. 
Bardzo ważną rolę w procesie ochrony zdrowia jest styl życia człowieka - jego nawyki oraz wzorce postępowania. Przybierają one formę czynników prozdrowotnych, poprawiających stan zdrowia, jak i czynników antyzdrowotnych wpływających negatywnie na zdrowie ${ }^{5}$.

Termin zdrowie funkcjonuje współcześnie nie tylko na gruncie medycyny czy nauk fizycznych, ale także pedagogiki, psychologii i socjologii. Zakres znaczenia pojęcia zależy więc od dyscypliny naukowej. Zdrowie należy do pojęć abstrakcyjnych, bardzo trudnych do zdefiniowania. Doliczono się ponad trzysta jego definicji, co wskazuje, że każda kolejna nie jest zadowalająca ${ }^{6}$.

Przez zachowania zdrowotne natomiast rozumie się wszelkie zachowania (nawyki, zwyczaje, postawy, wartości uznawane przez poszczególnych ludzi i przez grupy społeczne) w dziedzinie zdrowia, tzn. wskazujące na to, jakim jest człowiek pod względem zdrowotnym, jak pojmuje zdrowie, w jaki sposób nim dysponuje? .

Większość ludzi nie przykłada żadnej wagi do ukrytego znaczenia jedzenia i sposobu jego spożywania. Jakaż filozofia może się kryć za zaspokajaniem biologicznej potrzeby? Jednak wbrew pozorom zaspokajanie głodu to najmniej istotna funkcja jedzenia, bowiem posiada ono całą gamę symboli i znaczeń organizujących nasze życie ${ }^{8}$.

Dieta „specjalny system odżywiania się, polegający na dostosowaniu ilości i rodzaju pokarmu do potrzeb organizmu;

5 I. Heszen, H. Sęk, Behawioralne uwarunkowania zdrowia $i$ choroby, [w:] Psychologia zdrowia, red. I. Heszen, H. Sęk, Warszawa 2012, s. 90-104.

6 B. Woynarowska, Edukacja zdrowia, Warszawa 2008, s. 20.

7 U. Kempińska, Pedagogika społeczna wobec trudnych wyzwań wspótczesności, „Zeszyty Naukowe WSHE” 2014, t. XXXVIII, s. 83-91.

8 A. Frydrysiak, https://centrumzaburzenodzywiania.pl/strefaspecja listy/jedzenie-symboliczne-rola-pozywienia-w-zyciu-czlowieka/ [dostęp: 17.04.2017]. 
także w ogóle sposób odżywiania się": przepisać, zalecić, zastosować dietę, przestrzegać diety. łac. diaeta „zalecony sposób życia”, z gr. díaita „należyty sposób”

W niewielkich ramach niniejszego tekstu ograniczono się do omówienia elementów tradycyjnej diety azjatyckiej, w kontekście uwarunkowań pedagogiki społecznej. Na nich wspiera się metodyka, ta zaś trzyma się ogólnych reguł, znanych adeptowi pedagogiki. Artykuł ten jest tak skonstruowany, by przekonać czytelnika o powadze i głębi problematyki zdrowia, a przy tym wskazać jej związki z pedagogiką. W niniejszych rozważaniach przyjrzymy się jednemu z obszarów empirycznych dociekań współczesnej pedagogiki społecznej: zagadnieniom szeroko rozumianego zdrowia i jego promocji. W artykule dokonano przeglądu cech trzech tradycyjnych diet azjatyckich mieszkańców Japonii, Chin i Indii oraz zmian żywienia zachodzących w czasie, w kierunku tzw. niezdrowej „diety zachodniej”. Zmiany te zaszły zarówno u stałych mieszkańców tych państw, szczególnie w populacji miejskiej, jak i u imigrantów do Stanów Zjednoczonych i Europy Zachodniej. Ich ceną jest nasilenie występowania choroby niedokrwiennej serca, otyłości i cukrzycy. Tej ostatniej przede wszystkim w Indiach.

\section{Tradycyjna dieta azjatycka i jej wpływ na zdrowie}

Współcześnie duże zainteresowanie tradycyjną dietą azjatycką jest umotywowane niskimi wskaźnikami obecności choroby niedokrwiennej serca i innych chorób niezakaźnych, w tym chorób nowotworowych, w większości państw Azji. Wartość zdrowotna diety azjatyckiej jest porównywana do diety śródziemnomorskiej. Powszechnie tradycyjna dieta azjatycka cha-

9 M. Bańko, Wielki słownik wyrazów obcych PWN, Warszawa 2014. 
rakteryzuje się znaczną przewagą - w dziennym spożyciu produktów roślinnych nad produktami zwierzęcymi. Należy jednak pamiętać, że nie istnieje jedna dieta azjatycka, ponieważ występują różnice w spożyciu pomiędzy populacjami, nawet w obrębie jednego kraju, zazwyczaj uwarunkowane tradycją oraz religią. Generalizując można stwierdzić, że do produktów tradycyjnie spożywanych w Azji należy ryż i inne ziarna zbóż, ziemniaki, w tym pataty, makarony, owoce i warzywa (także pochodzenia morskiego), nasiona roślin strączkowych, soja (tofu, makaron sojowy, sos sojowy), oleje roślinne, nasiona, przyprawy, herbata i alkohol. Zawartość tłuszczu w tradycyjnej diecie azjatyckiej jest niewielka, w tym w szczególności tłuszczu nasyconego. Zwraca uwagę fakt małej ilości lub nawet brak produktów mlecznych w diecie mieszkańców Azji Wschodniej i Południowej, za wyjątkiem Indii. Na ogół małe lub umiarkowane jest spożycie ryb, za wyjątkiem wyspiarzy i mieszkańców regionów nadmorskich. W związku z postępującą globalizacją obserwuje się niestety w krajach Azji odchodzenie od tradycyjnej diety, na rzecz tzw. „diety zachodniej”. Jednym z przykładów globalizacji pod tym względem jest pojawianie się coraz więcej restauracji i barów z zachodnią żywnością typu ,fast food"10.

Na profilaktyczne działanie tradycyjnej diety japońskiej wskazało badanie przeprowadzone w latach 60. ubiegłego wieku pod kierunkiem znanego amerykańskiego badacza Ancela Keysa $^{11}$. Jest to prospektywna obserwacja dokonana w siedmiu

10 B. Cybulska, D. Szostak-Węgierek, Tradycyjna dieta azjatycka. Dlaczego chroni przed zawatem serca?, "Problemy Higieny i Epidemiologii” 2012, nr 93 (1), s. 172-177; por. A. Kobylańska, Jedzenie a miłość, czyli przez żołądek do serca, Toruń 2019; eadem, Kraina smaku w pojemniku, Toruń 2017.

11 Por. A. Keys, Coronary heart disease in seven countries, "Circulation” 1970, vol. 41 (1), s. 1-195; D. Kromhout, A. Keys, Aravanis C et al. Food consumption patterns in the 1960s in seven countries, „The American Journal of Clinical Nutrition" 1989, vol. 49, s. 889-894. 
krajach (Japonia, Grecja, dawna Jugosławia, Włochy, Holandia, Stany Zjednoczone Ameryki i Finlandia). W szesnastu próbach populacji z tych państw dokonano oceny sposobu żywienia, następnie notując w kolejnych latach zgony na choroby niedokrwiennej serca. Już po dziesięciu. latach obserwacji okazało się, że najmniej zgonów z tego powodu wystąpiło w populacjach japońskich. W kolejności po populacjach japońskich, pod względem niskich wskaźników umieralności na choroby niedokrwiennej serca, zajęły populacje krajów śródziemnomorskich (Grecja, Włochy i Jugosławia), gdzie również obserwowano niskie poziomy cholesterolu i małe spożycie nasyconych kwasów tłuszczowych, pomimo dużego udziału tłuszczu ogółem (głównie oleju oliwkowego). Na przeciwległym biegunie znalazły się Finlandia, Holandia i USA z wysokimi wskaźnikami zgonów wieńcowych, wysokimi średnimi stężeniami cholesterolu i dużym spożyciem nasyconych kwasów tłuszczowych. Badanie wykazało korzyści dla serca przy małym spożyciu nasyconych kwasów tłuszczowych. Następnie dokonano analizy innych cech diety japońskiej i diety śródziemnomorskiej, które mogły dodatkowo wpływać korzystnie na ryzyko choroby niedokrwiennej serca. Do tych cech należą: w Japonii spożycie ryb, produktów sojowych, warzyw i ryżu, a w krajach śródziemnomorskich spożycie oleju oliwkowego, warzyw, owoców, ryb i wina ${ }^{12}$.

Japończycy należą do populacji najdłużej żyjących na świecie. Kobiety zajmują pod tym względem pierwsze miejsce, a mężczyźni drugie. Ten korzystny fakt przypisuje się w dużym stopniu zdrowemu stylowi życia, w tym tradycyjnej diecie, która jest ubogoenergetyczna i cechuje się wysoką wartością odżywczą. W małej objętości posiłków znajduje się duża zawartość witamin, składników mineralnych i antyoksydantów,

12 B. Cybulska, D. Szostak-Węgierek, Tradycyjna..., op.cit. 
w tym flawonoidów. Badania Japończyków żyjących w Japonii i imigrantów japońskich w Stanach Zjednoczonych potwierdzają pogląd o kluczowym znaczeniu sposobu żywienia dla ekspresji czynników ryzyka, w tym stężenia cholesterolu oraz dla występowania choroby niedokrwiennej serca ${ }^{13}$.

Tradycyjna dieta Chińczyka opiera się na ryżu, produktach zbożowych i sojowych oraz warzywach. $Z$ powodu nietolerancji mleka większość Chińczyków spożywa niedużą ilość produktów mlecznych, zastępując je mlekiem sojowym i tofu (rodzaj twarogu otrzymywanego z mleka sojowego). Do potraw stosuje się olej sojowy oraz z orzeszków ziemnych. W latach 1982-1992 wystąpiły w Chinach zmiany żywienia z tradycyjnego w kierunku diety „zachodniej”. Szczególnie duże zmiany żywienia obserwowano w tym czasie w Pekinie. W ślad za zmianami żywienia $\mathrm{w}$ kierunku aterogennym ${ }^{14}$ od wczesnych lat 80 . XX w. wzrosły w Chinach zgony z powodu chorób niedokrwiennych serca, w szczególności w populacjach miejskich ${ }^{15}$.

Indie od lat 50. XX w. doświadczają stałego wzrostu ekonomicznego. W ślad za rozwojem społeczno-ekonomicznym i ustąpieniem głodu wydłużyła się długość życia. Drugim osiągnięciem zdrowotnym jest spadek umieralności niemowląt. Hindusi tradycyjnie są wegetarianami. Spożywają głównie produkty zbożowe (pszenne), rośliny strączkowe (soja, soczewica), ryż i warzywa, a spośród tłuszczów różne oleje roślinne oraz klarowane masło (ghee). W Indiach postępują zmiany sposobu żywienia w kierunku „zachodniej diety”, szybciej na zurbanizowanej i uprzemysło-

\section{Ibidem.}

14 Wskaźnik aterogenności, wskaźnik miażdżycowy - termin używany w medycynie służący do określenia wzajemnych stosunków między lipidami występującymi we krwi. Przekroczenia wartości prawidłowych danych wskaźników wiązane są ze zwiększeniem ryzyka rozwoju miażdżycy i wskazuje konieczność interwencji dietetycznej i/lub farmakologicznej.

15 B. Cybulska, D. Szostak-Węgierek, Tradycyjna..., op.cit. 
wionej północy, aniżeli na rolniczym południu kontynentu - i co oczywiste - w miastach. Duże jest spożycie cukru i żywności bogatej w tłuszcz. Wzrosło spożycie nasyconych kwasów tłuszczowych. Hindusi, zarówno w Indiach, jak i w USA, mają najwyższe wskaźniki zgonów wieńcowych na świecie, ponadtrzykrotnie większe niż w Stanach Zjednoczonych. Ma to związek z wydłużaniem się życia populacji, wtórnie do wzrostu dochodu na głowę ludności i spadku umieralności niemowląt, o czym już wspomniano wyżej. Drugą przyczyną jest wzrost występowania czynników ryzyka, wtórnie do zmiany żywienia ${ }^{16}$.

Zgony wieńcowe są jednak zróżnicowane, pomiędzy ludnością miejską i wiejską, co jest w znacznym stopniu związane z różnicą w zamożności, i tym samym dostępem do droższej aterogennej żywności ${ }^{17}$. Hindusi żyjący na zurbanizowanej północy mają wysokie stężenie trójglicerydów i małe cholesterolu HDL, wewnątrzbrzuszną dystrybucję tkanki tłuszczowej oraz często chorują na cukrzycę ${ }^{18}$.

\section{Dziesięć zasad skutecznej diety Azjatów}

Pomimo rosnącej fali nadwagi i otyłości Azja ciągle pozostaje „zieloną wyspą" na mapie. Procentowy udział osób otyłych jest na tym kontynencie stosunkowo niski, pomimo rosnących jak wszędzie - wskaźników. Dlaczego tak się dzieje? Co cechuje państwa azjatyckie?

16 V. Singh, P. Deedwania, Dyslipidemia in special populations: Asian Indians, African Americans, and Hispanics, "Current Atherosclerosis Reports" 2006, vol. 8, s. 32-40.

17 S.I. Chadha, N. Gopinath, I. Kkathyal, Dietary profile of adults in a urban and rural community, „Indian Journal of Medical Research” 1995, vol. 101, s. 258-267.

18 A. Misra, R.M Pandey, J.R. Devi et al. High prevalence of diabetes, obesity and dyslipidemia in urban slum population in northern India, „International Journal Obesity” 2001, vol. 25, s. 1722-1729. 


\section{1) Podejście do jedzenia}

W państwach azjatyckich stosunek do jedzenia jest zupełnie inny, aniżeli w przypadku znanej nam „diety zachodniej”. W naszych regionach je się raczej, aby zaspokoić głód lub dla przyjemności. Podczas gdy w Azji stosunek do jedzenia jest inny. Je się tam, aby uzdrowić organizm. Każdy zjadany składnik posiada jakieś zadania. Może on uzdrowić lub odsunąć chorobę. Opierają oni - w dużej mierze - swoje żywienie o kuchnię pięciu przemian, co za tym idzie jest to cała filozofia, podczas gdy w Polsce, gdy czujemy przeziębienie, sprowadza się to najczęściej do zjadania czosnku.

Wniosek: odpowiedni stosunek do jedzenia pozwala lepiej kontrolować ilość zjadanych kalorii.

2) Rozmiar porcji

Od zawsze w kulturze europejskiej na stołach panował przesyt. Skromna uczta była kojarzona raczej z biednymi czasami, natomiast w krajach Wschodu od zawsze panowała harmonia. Mawiają oni przed ucztą: zjedz tak abyś był w $80 \%$ najedzony. Widać to również na przestrzeni dziejów w sztuce, na obrazach widać skromnie zastawione stoły, dużo przestrzeni. Podczas gdy nasze obrazy zawsze charakteryzowały się przesytem podczas uczt, a stoły uginały się od ilości pożywienia.

Wniosek: wielkość porcji przekłada się na niższą masę ciała.

3) Metody gotowania

W kuchni azjatyckiej główną metodą przygotowywania potraw jest gotowanie wodne lub na parze, znane już od tysiącleci. Często zdarza się też szybkie obsmażanie tak, aby warzywa nie straciły cennych witamin i właściwości. Azjaci rzadko kiedy jedzą surowe warzywa. Według medycyny chińskiej lekkie ich ogrzanie powoduje lepszą strawność i przyswojenie składników odżywczych. 
Wniosek: źródła historyczne podają, że w Chinach już trzy tysiące lat temu znano metodę gotowania na parze. Jest to stosunkowo nowy trend z nurtu tak zwanego healthy eating ${ }^{19}$.

4) Dodatek żywności fermentowanej

Zupa mięso, natto, kimchi ${ }^{20}$, sos sojowy - można by wymieniać długo. W Azji kiszone jest praktycznie wszystko. Ma to też bezpośredni wpływ na zdrowie. Produkty kiszone zawierają probiotyki (żywe bakterie niezbędne do prawidłowego funkcjonowania układu trawiennego; także produkt spożywczy, zwłaszcza jogurt, zawierający takie bakterie), które świetnie działają na mikroflorę jelit. Zastępują tym samym potrzebę przyjmowania dodatkowych suplementów.

Wniosek: dobrze działająca mikroflora jelit poprawia odporność organizmu oraz pozwala regulować apetyt.

5) Więcej ryb i owoców morza

Większość organizmu człowieka to woda, a woda jest pierwiastkiem życia. Niestety Europejczycy (szczególnie Polacy) mogą się „pochwalić” bardzo małą ilością zjadanych produktów morskich. Czasami występuje smażona ryba na piątkowy obiad. Jak pokazują dane statystyczne najzdrowsze narody w większości zamieszkują przy basenach morskich i oceanach. W regionach tych je się duże ilości ryb i owoców morza, ale także cennych wodorostów, produktów bogatych w kwasy tłuszczowe omega 3 oraz jod, cynk i selen.

Wniosek: należy pamiętać, aby częściej niż raz w tygodniu włączyć rybę do naszego jadłospisu. Przyniesie to więcej korzyści niż może się wydawać.

19 H. Eating, Simple Ways to Plan, Enjoy, and Stick to a Healthy Diet, https://www.helpguide.org/articles/healthy-eating/healthy-eating.htm/ [dostęp: 17.04.2019].

20 Spicy Kimchi Natto (Fermented Soy Beans) Side Dish, https:// www.thespruceeats.com/spicy-kimchi-natto-side-dish-2030913 [dostęp: 17.04.2019]. 
6) Zielone warzywa

Zielone warzywa są wyjątkowo niskokaloryczne. Świetnie sycą za sprawą zawartego w nich błonnika, a dodatkowo dostarczają cennych witamin i minerałów. Według założeń diety MIND ${ }^{21}$ jedzenie trzech porcji zielonych warzyw dziennie powoduje, że nie ma potrzeby liczenia zjadanych kalorii.

Wniosek: w zdrowej i zbilansowanej diecie nie powinno zabraknąć niskokalorycznych zielonych warzyw. Najlepiej codziennie.

7) Zielona herbata

Badania nad wpływem zielonej herbaty na masę ciała cały czas trwają. Jednak już teraz znamy kilka składników tego napoju, pozwalającego ograniczyć głód, zmniejszyć masę ciała oraz poprawić długość życia. Ponadto wypicie filiżanki zielonej herbaty po posiłku sprawi, że szybciej poczuje się sytość.

Wniosek: herbata jest praktycznie bezkalorycznym napojem, o cennych właściwościach. Może również wspomagać odchudzanie.

8) Zdrowe desery i przekąski

Dieta bez piekarni ociekających cukrem oraz tłuszczem i bez pączków smażonych na głębokim oleju. Desery w kuchni azjatyckiej często oparte są na ryżu, fasoli, algach i wodorostach z dodatkami orzechów oraz owoców.

Wniosek: zdrowe przekąski zdecydowanie nie przyczynią się do nadprogramowych kilogramów. Deser może uchronić od wizyty u dietetyka.

9) Chodzenie, wędrowanie

Chodzenie, to podstawowa czynność do jakiej jest stworzony ludzki organizm. Azjaci dużo więcej chodzą niż statystycz-

21 Dieta MIND - zalety $i$ wady, https://www.akademiadietetyki.pl/ dietetyka/dieta-mind-zalety-i-wady/ [dostęp: 17.04.2019]. 
ny Europejczyk. Ich nawyki wiążą się między innymi z dużą gęstością zaludnienia, gdzie samochody stają się niewygodne do codziennego użytku. Aby zrobić zakupy czy też wybrać się do pralni - wybierają oni najczęściej spacer.

Wniosek: każda dodatkowa spontaniczna aktywność fizyczna, jak spacer wpływa bardzo korzystnie na wagę oraz ilość spalanych kalorii. Należy pamiętać, że już 10 tys. kroków dziennie pozwoli o wiele lat przedłużyć w zdrowiu nasze życie.

10) Aktywność fizyczna i medytacja

Aktywność fizyczna w krajach azjatyckich jest częścią kultury. Szczególnie zauważa się to u osób starszych, kiedy posiadają wreszcie wystarczającą ilość czasu, aby móc dowolnie spędzać czas na świeżym powietrzu, wspólnie grając i bawiąc się.

Wniosek: spędzajmy czas na świeżym powietrzu, a nie na kanapie.

Pomimo że te dziesięć sposobów pochodzi praktycznie z drugiego końca świata nie ma przeciwwskazań, aby włączyć je do codziennego życia. Z pewnością odbije się to pozytywnie na zdrowiu i masie ciała. Szczególnie mieszkańcy dużych miast powinni zwrócić uwagę na tych kilka prostych zasad. Uchronią one od nadmiernego stresu oraz wspomogą odchudzanie i zachowanie zdrowia na lata i to jest właśnie pedagogika społeczna.

\section{Podsumowanie}

W artykule dokonano przeglądu związku żywienia z wybranymi chorobami (chorobą niedokrwienną serca) w trzech populacjach azjatyckich (japońskiej, chińskiej i hinduskiej), ze względu na ich największą liczebność i na najlepszą dostępność do danych. Te trzy państwa Azji nie tylko mają przewagą 
nad innymi, w odniesieniu do liczby ludności, ale także przewagę pod względem imigracji do Ameryki i Europy.

Jak wynika z nagromadzonej wiedzy tradycyjna dieta azjatycka ma kardioprotekcyjne działanie podobne do diety śródziemnomorskiej. Niekorzystne zmiany w sposobie żywienia w Chinach i w Japonii w kierunku diety „zachodniej”, chociaż stale postępują, nie zaszły aż tak głęboko jak zmiany w tradycyjnej diecie mieszkańców Indii. Jeśli chodzi o Japończyków, to pomimo wzrostu spożycia żywności, utrzymało się duże spożycie żywności chroniącej przed rozwojem miażdżycy. $Z$ tego powodu Japończycy nadal należą do populacji najdłużej żyjących na świecie.

W Indiach zmiany żywienia nastąpiły gwałtownie wraz z zieloną rewolucją. Szybko poprawiła się dostępność łatwo przyswajalnych węglowodanów (skrobia pszeniczna) oraz wzrosło spożycie tłuszczu. W ślad za tym zwiększyło się występowanie otyłości z wewnątrzbrzuszną dystrybucją tkanki tłuszczowej, zespołu metabolicznego i cukrzycy typu 2, co powoduje duże zagrożenie niedokrwienną chorobą serca. Rozpowszechnienie tych czynników zależy od stylu życia, w szczególności od sposobu żywienia i jest zróżnicowane pomiędzy krajami, z mniejszą ekspresją w Japonii i w Chinach niż w Indiach. Z drugiej strony mieszkańcy państw zachodnich mogą czerpać z diety azjatyckiej to, co służy zdrowiu. Należy pamiętać, że w naszym kręgu kulturowym tradycyjna dieta śródziemnomorska stale pozostaje najlepszym modelem żywienia ${ }^{22}$.

22 Wykonano na podstawie: Bdieta.pl, 10 zasad skutecznej diety Azjatów - zastosuj je sam!, http://bdieta.pl/10-zasad-skutecznej-diety-azjatow/ [dostęp: 17.04.2019]. 


\section{Bibliografia}

Bańko M., Wielki słownik wyrazów obcych PWN, Warszawa 2014.

Chadha S.I., Gopinath N., Kkathyal I., Dietary profile of adults in a urban and rural community, „Indian Journal of Medical Research" 1995, vol. 101.

Cybulska B., Szostak-Węgierek D., Tradycyjna dieta azjatycka. Dlaczego chroni przed zawałem serca?, „Problemy Higieny i Epidemiologii” 2012, nr 93 (1).

Górak-Sosnowska K., Jurewicz J. (red.), Kulturowe uwarunkowania rozwoju w Azji i Afryce, Łódź 2010.

Heszen I., Sęk H., Behawioralne uwarunkowania zdrowia i choroby, [w:] Psychologia zdrowia, red. I. Heszen, H. Sęk, Warszawa 2012.

Kempińska U., Pedagogika społeczna wobec trudnych wyzwań wspótczesności, „Zeszyty Naukowe WSHE” 2014, t. XXXVIII.

Keys A., Coronary heart disease in seven countries, „Circulation" 1970, vol. 41 (1).

Kobylańska A., Jedzenie a miłość, czyli przez żołądek do serca, Toruń 2019.

Kobylańska A., Kraina smaku w pojemniku, Toruń 2017.

Kromhout D., Keys A., Aravanis $C$ et al. Food consumption patterns in the 1960s in seven countries, „The American Journal of Clinical Nutrition” 1989, vol. 49.

Mazurkiewicz E., Podstawy wychowania zdrowotnego, [w:] Higiena i ochrona zdrowia, red. Z. Brzeziński, C.W. Korczak, Warszawa 1975.

Misra A., Pandey R.M., Devi J.R., et al., High prevalence of diabetes, obesity and dyslipidemia in urban slum population in northern India, „International Journal Obesity” 2001, vol. 25.

Przecławska A. (red.), Pedagogika społeczna, kręgi poszukiwań, Warszawa 1996. 
Radziewicz-Winnicki A., Pedagogika społeczna, Warszawa 2008.

Singh V., Deedwania P., Dyslipidemia in special populations: Asian Indians, African Americans, and Hispanics, „Current Atherosclerosis Reports" 2006, vol. 8.

Woynarowska B., Edukacja zdrowia, Warszawa 2008.

\section{Żródła internetowe}

Aleksandra Frydrysiak, https://centrumzaburzenodzywiania. $\mathrm{pl} /$ strefaspecjalisty/jedzenie-symboliczne-rola-pozywienia -w-zyciu-czlowieka/.

Bdieta.pl, 10 zasad skutecznej diety Azjatów - zastosuj je sam!, http://bdieta.pl/10-zasad-skutecznej-diety-azjatow/.

Dieta MIND - zalety $i$ wady, https://www.akademiadietetyki. $\mathrm{pl}$ /dietetyka/dieta-mind-zalety-i-wady/.

Healthy Eating. Simple Ways to Plan, Enjoy, and Stick to a Healthy Diet, https://www.helpguide.org/articles/healthy-eating/healthy-eating.htm/.

Preamble to the Constitution of the World Health Organization as adopted by the International Health Conference, New York, 19 June-22 July 1946, http://www.who.int/en/. Spicy Kimchi Natto (Fermented Soy Beans) Side Dish, https://www.thespruceeats.com/spicy-kimchi-natto-sidedish-2030913.

\section{Abstrakt}

Pedagogika społeczna to subdyscyplina naukowa, dział pedagogiki zajmujący się tradycyjnie środowiskowymi uwarunkowaniami wszelkich procesów opiekuńczo-wychowawczych i rozwoju jednostki, w różnych fazach życia człowieka. Wśród wielu czynników oddziałujących na zdrowie człowieka zasadnicze znaczenie odgrywa żywienie. Zdrowe, racjonalne żywienie jest jedną z podstawowych potrzeb człowieka 
i warunkiem prawidłowego rozwoju, dobrego samopoczucia oraz pełnej dyspozycji do uczenia się.

Jednym z najważniejszych elementów zdrowego trybu życia jest sprawność fizyczna i ... dieta. W większości państw dalekiej Azji, takich jak Indie, Japonia, Chiny, Sri Lanka, Tajlandia, Wietnam, Kambodża i Korea, zarówno choroba niedokrwienna serca, jak i nowotwory należą do rzadkości. Wielu autorów tłumaczy to zjawisko ochronną rolą diety

stosowanej od pokoleń przez mieszkańców tamtych regionów. Uważa się, że jej wartość zdrowotna jest zbliżona do diety śródziemnomorskiej.

Słowa kluczowe: pedagogika społeczna, wychowanie, dieta azjatycka, żywienie, edukacja, zdrowie

\section{Abstract}

Social pedagogy is a scientific subdiscipline, a department of pedagogy dealing traditionally with the environmental conditions of all care and educational processes and the development of the individual in various phases of human life. Among many factors affecting human health, nutrition plays a crucial role. Healthy, rational nutrition is one of the basic human needs and a condition for proper development, well-being and full disposition for learning.

One of the most important elements of a healthy lifestyle is physical fitness and... diet. In most Far Asian countries such as India, Japan, China, Sri Lanka, Thailand, Vietnam, Cambodia and Korea, both ischemic heart disease and tumors are rare. Many authors explain this phenomenon as the protective role of the diet used for generations by the inhabitants of those regions. It is believed that its health value is similar to the Mediterranean diet.

Keywords: social pedagogy, upbringing, Asian diet, nutrition, education, health 


\section{Renata Gałaj-Dempniak}

Uniwersytet Szczeciński

ORCID ID: https://orcid.org/0000-0001-9006-6633

\section{Problem marnowania żywności w Japonii}

Współczesne społeczeństwa niezależnie od zamożności państwa mają podobne problemy z żywnością. Polegają one głównie na nadmiernym gromadzeniu zapasów żywności, które ulegają zepsuciu niespożyte w terminie, braku dostatecznej ilości wartościowej żywności w najuboższych grupach społeczeństw, co powoduje głód, niedożywienie, konieczność zabiegania o pozyskanie pokarmu. Powstające odpady mają zaś negatywny wpływ na środowisko i przyczyniają się do powstawania efektu cieplarnianego. Powstaje problem ich bezpiecznego składowania oraz utylizacji, generujące wysokie koszty. Marnotrawiona żywność nie pozostaje bez wpływu na gospodarkę państwa, zwłaszcza kiedy musi być importowana a ostatecznie część jej ulega zniszczeniu. Japonia także nie jest wolna od tych zjawisk. Zarówno rządzący, jak i większość obywateli rozumieją, że istnieje problem marnotrawienia pokarmu. Próbuje się go rozwiązać na różne sposoby. Na jego powstanie wpływa nie tylko tradycja kulinarna, sposób konsumpcji, ale i istniejące a nieadekwatne do obecnych czasów przepisy prawne, które zdaniem niektórych wymuszają nadprodukcję, a w konsekwencji prowadzą do marnotrawienia żywności ${ }^{1}$.

1 Japan throws out 620,000 tons of food a year, while 3 mil kids don't have enough to eat, „Japan Today”, https://japantoday.com/category/features/ kuchikomi/Japan-throws-out-620-000-tons-of-food-a-year-while-3-milkids-don\%27t-have-enough-to-eat [dostęp: 10.01.2019]. 
Coraz częściej nawiązuje się w życiu publicznym do koncepcji „mottanai”, czyli braku akceptacji i niezadowolenia z marnotrawienia pokarmu ${ }^{2}$. Innym czynnikiem jest turystyka, zwłaszcza goście z zagranicy, którzy w dużych miastach, jak Tokio, napędzają niektóre z sektorów gospodarki. Tutaj odpady i śmieci stały się dużym i naglącym problemem do rozwiązania ${ }^{3}$.

Statystyki w zakresie marnotrawienia żywności prowadzi się dopiero od 2012 r. Wcześniej określano je szacunkowo w oparciu o ilość produkowanych śmieci w przeliczeniu na jedną osobę. W 2016 r. Japonia była w pierwszej trójce państw marnujących masowo produkty żywnościowe ${ }^{4}$. W 2018 r. podano w mediach, że wyrzucano 620 tys. ton żywności rocznie ${ }^{5}$. Podobne szacunki posiada japońskie Ministerstwo Rolnictwa, Leśnictwa i Rybołówstwa. Około 339 tys. ton marnotrawią przemysł, restauracje i supermarkety, resztę odpadków produkują gospodarstwa domowe. Żeby lepiej uzmysłowić sobie rozmiar strat, jest to żywność, którą można przez rok karmić mieszkańców Tokio, czyli 13 mln ludzi. Dziennie na osobę jest to średniej wielkości miska ryżu w skali całego państwa. W Kioto z 1,4 mln mieszkańców rocznie wyrzuca się 64 tys. ton jedzenia, co stanowi ok. 1\% wyrzucanej w Japonii żywności ${ }^{6}$. Władze tego miasta chcą do 2020 r. zmniejszyć marnotrawstwo w tym sek-

2 Mottainai! What a Waste! Japan staves off the worst of "food waste culture”, FAO, http://www.fao.org/save-food/news-and-multimedia/news/ newsdetails/ru/c/1036297/ [dostęp: 14.01.2019].

3 E. Johnston, For Kyoto, a chance to lead Japan in fight against food loss, „The Japan Times”, https://www.japantimes.co.jp/news/2018/10/20/ national/kyoto-chance-lead-japan-fight-food-loss/\#.XKsqTdgwjcs. [dostęp: 12.01.2019].

4 K. Diep, Food Waste Around the World: Japan; https://theculinologist. wordpress.com/2016/07/07/food-waste-around-the-world-japan/ [dostęp: 3.01.2019].

5 Japan throws out 620,000 tons..., op.cit.

6 E. Johnston, For Kyoto, a chance to lead Japan in fight against food loss..., op.cit. 
torze do 50 tys. ton. W 2018 r. Ministerstwo Środowiska Japonii planowało przedłożyć rządowi do zatwierdzenia ramowy plan do ustawy o promowaniu postaw ekologicznych. Jednym z założeń jest dążenie do obniżenia o połowę ilości marnowanego jedzenia w 2030 r. w porównaniu z 2000 r. ${ }^{7}$ W 2000 r., wg danych Ministerstwa Rolnictwa, Leśnictwa i Rybołówstwa wyrzucono 5,47 mln ton żywności, w 2030 r. zmarnowana żywność nie powinna, wg założeń, przekroczyć wielkości wyższej niż $2,73 \mathrm{mln}$ ton $^{8}$. O ile ustawodawstwo w Japonii narzuca przedsiębiorstwom konieczność minimalizowania marnotrawienia żywności, o tyle zwykłych obywateli takie przepisy nie dotyczą.

Wśród odpadów znajdują się niestety także produkty nadające się nadal do spożycia. Kupujący zmienił bowiem zdanie, stracił apetyt na zakupioną żywność, kupił jej za dużo, bez zastanowienia się. Poniósł koszty, wydatek musi zaliczyć więc do zmarnowanych pieniędzy. Uszczerbek ponosi także państwo, bo musi uporać się teraz z produktem, który należy zutylizować. Japonia poświęciła sporo wysiłku, aby stworzyć system recyklingu, dzięki któremu obniża się koszty marnotrawienia. W działaniach na rzecz zahamowania marnotrawstwa żywności stworzono rządowy system współpracy pomiędzy ministerstwami: Agencji do Spraw Konsumentów, Ministerstwem Edukacji, Kultury, Sportu, Nauki i Technologii, Ministerstwem Środowiska, Ministerstwem Gospodarki, Handlu i Przemysłu oraz Ministerstwem Rolnictwa, Leśnictwa i Rybołówstwa. Poprawie sytuacji ma także sprzyjać opracowany system monitorowania żywności.

A. Stasiak, Japonia zapowiada walkę z marnowaniem żywności, http://www.polska-azja.pl/japonia-zapowiada-walke-z-marnowaniem-zywnosci/ [dostęp: 11.06.2018].

8 A ducument concerning "Reducing food loss and waste in Japan", which was used in APEC 2019 Expert Consultation, MAFF, http://www. maff.go.jp/e/policies/env/attach/pdf/frecycle-5.pdf, August 2019 [dostęp: 11.01.2019]. 
W 2019 r. prasa japońska donosiła, że ok. 40\% marnowanej żywności pochodzi z gospodarstw domowych. W przeprowadzonej ankiecie internetowej prawie 75\% respondentów przyznało się, że zna problem marnotrawienia żywności, w tym prawie $70 \%$ dostrzega go w swoich działaniach i próbuje to zmieniać. Tylko $38 \%$ respondentów wiedziało o działalności banków żywności, do których mogą oddać niechciane produkty. Większość uczestników zadeklarowała, że po prostu stara się kupować żywność o długich terminach przydatności do spożycia, licząc że zdążą ją skonsumować. W sprzedaży detalicznej marnuje się w Japonii zaś ok. 10\% ${ }^{9}$. Reszta wyrzucanej żywności przypada na szeroko pojęty przemysł spożywczy i produkcję rolną.

Pilotażowe działania mające zredukować to zjawisko podjęto w różnej wielkości ośrodkach. Mają one formy uzależnione od potrzeb i możliwości zamieszkującej społeczności. W 2001 r. uchwalono ustawę o recyklingu żywności ${ }^{10}$. Wymaga ona od rządu opracowania podstaw polityki, ram rozwiązania problemu „utraty żywności” i nakłada na samorządy obowiązek opracowania szczegółowych planów działania. Szczególnie ciekawym rozwiązaniem są tzw. pętle recyklingu, które doprowadziły do zmniejszenia emisji gazów cieplarnianych i pozytywnie wpłynęły na wyniki ekonomiczne, dzięki procesowi utylizacji odpadów. Japończycy coraz częściej uwzględniają fakt, że żywność produkowana jest w Japonii m.in. dzięki importowi pasz. Duża część drogo opłaconej produkcji nie może być marnowana. Zdecydowano więc, że należy rozpocząć recykling odpadów spożywczych, z przeznaczeniem ich

9 Ankieta, 3000 dorosłych respondentów, Agencja do Spraw Konsumenckich, Addressing the nation's food waste problem, „The Japan Times”, https://www.japantimes.co.jp/opinion/2019/05/26/editorials/addressing-nations-food-waste-problem/\#.XX842X8wjcs [dostęp: 26.05.2019].

10 Food Recycling Law, inaczej zwana the Promotion of Utilization of Recyclable Food Waste Act. 
m.in. na paszę. Import pasz miał dzięki temu ulec zmniejszeniu, zwiększyć się zaś produkt krajowy i samowystarczalność państwa, która wg prowadzonych symulacji wzrosłaby w ten sposób z 26 do 38\% w 2020 r. Pomimo wprowadzenie pętli recyklingowych w 2015 r. nadal 80\% odpadów spożywczych była palona $^{11}$. Japonia z zainteresowaniem przyjęła program Organizacji ds Wyżywienia i Rolnictwa przygotowany dla państw Azji i Pacyfiku w zakresie ochrony zasobów żywności i niemarnotrawienia jej ${ }^{12}$. FAO ściśle współpracuje z Biurem ds. Przemysłu Spożywczego Ministerstwa Rolnictwa, Leśnictwa i Rybołówstwa i przedsiębiorstwami sektora publicznego oraz prywatnego w Japonii. Państwu pomaga lokalna administracja, która pozytywnie nastawiona jest do promowanych zmian ${ }^{13}$. W ramach podjętych działań prowadzi się: akcje uświadamiające, które mają skutkować tym, że ludzie kupią mniej żywności, aby nie wyrzucać pokarmu, którego nie są w stanie skonsumować. Do tej kategorii zalicza się akcje prowadzące do logicznego gospodarowania zgromadzonymi zapasami, tzn. spożywania najpierw najwcześniej zakupionych produktów lub z najkrótszą datą przydatności do spożycia. Prowadzi się programy adresowane do grup wiekowych i branżowych. Akcje organizowane od 2012 r. rozpoczęto od dzieci szkolnych, następnie opracowano programy nakierowane na młodzież i naukowców, przemysłowców i media oddziałujące na całe społeczeństwo. Państwo dostrzega wysiłki społeczności lokalnych, czego wyrazem są

11 Japan throws out 620,000 tons..., op.cit. Wg danych Ministerstwa Rolnictwa w 2015 r. 77\% jest albo spalane, albo kompostowane, ale z 23\% wyrzuconej żywności nic się nie robi, za: A. Stasiak, Japonia zapowiada walkę $z$ marnowaniem żywności..., op.cit.

12 Food and Agriculture Organization of the United Nations.

13 Nagoya community effort to recycle food waste wins U.N.-related award, „The Japan Times”, https://www.japantimes.co.jp/news/2018/12/24/ national/nagoya-community-effort-recycle-food-waste-wins-u-n-relatedaward/\#.XKsp3Ngwjcs [dostęp: 5.02.2019]. 
nagrody rozdawane przez Japońską Komisję ds. Dekady Różnorodności Biologicznej ${ }^{14}$. Przykładem jest społeczność Nagoi nagrodzona za wysiłki na rzecz recyklingu odpadów spożywczych pochodzących z supermarketów i lunchów szkolnych, wykorzystywanych do wytworzenia kompostu do uprawy warzyw. Projekt recyklingu Okaeri Yasai ${ }^{15}$ rozpoczęto w 2008 r. Inicjatorem był prof. nadzwyczajny Tomoko Okayamy prowadzący badania środowiskowe na Uniwersytecie Taisho, wykładający w tym okresie w Nagoi. Podjęte działania pozwoliły zmniejszyć ilość nawozów sztucznych w uprawach lokalnych. Warzywa uprawiane w okolicy na kompoście są następnie sprzedawane w lokalnych supermarketach. Lokalny hotel w swoim menu oferuje specjalne dania z lokalnych produktów z upraw ekologicznych. Recykling nie tylko nakręca lokalną gospodarkę, ale i ogranicza ilość chemii w produkcji rolnej. Władze miasta organizują w ramach ścieżki edukacyjnej wycieczki szlakiem recyklingu.

Oddziaływanie na społeczność Japonii odbywa się poprzez imprezy naukowe, wycieczki, ścieżki edukacyjne, muzykę, konkursy itp. Pozwala zaangażować w działania ludzi, którzy pod bezpośrednim wpływem prowadzonych samodzielnie działań, powoli przekonują się do zasadności koncepcji szanowania żywności i recyklingu odpadów spożywczych. Zwiększa to świadomość istnienia problemu, zmniejsza opór przed wprowadzanymi zmianami, wymagającymi od ludzi podjęcia

14 Ibidem. Nagroda Biodiversity Action Award. „the Japan Committee for UNDB selected the project as one of the recipients of its Biodiversity Action Award, which highlights community activities linked to the preservation and sustainable use of biodiversity. The UNDB was adopted in 2010 by the U.N. General Assembly and covers from 2011 to 2020, based on a recommendation made by the Japanese government during the 10th meeting of the Conference of the Parties (COP10) to the Convention on Biological Diversity held in Nagoya the same year".

15 Welcome Back Vegetables - Witajcie z powrotem warzywa. 
działań w nowym obszarze (zajęcia z segregacji, produkcji kompostu, gotowania). Media informują także o problemie marnotrawstwa żywności na świecie i jak walczą z nim inne narody ${ }^{16}$. We współpracy np. z Polską powstał projekt Do You Kyoto? Czy robisz coś dobrego dla środowiska? ${ }^{17}$. We współpracy z Japonią ogłoszono konkurs na wykonanie upcyclingowej maskotki oraz ułożenie „ekologicznego” tekstu piosenki, która miała być śpiewana do znanej w Polsce melodii „Szła dzieweczka do laseczka”.

W ramach edukacji proekologicznej ludzi uczy się właściwego układania w lodówkach produktów, tak aby te o najkrótszych datach przydatności leżały najbliżej. Dodatkowo znakowania zakupionego towaru, aby wiedzieć kiedy był zakupiony i zdążyć zjeść pokarm na czas. Niby jest to oczywiste, ale ile osób świadomie stosuje się do tych zasad na co dzień? Problemem w Japonii (ale jak się wydaje i w innych państwach) jest tłumaczenie i rozumienie terminu zjeść przed... (shômikigen). Jeżeli zje się niektóre produkty do dwóch tygodni po dacie na opakowaniu, to człowiekowi nic nie powinno się stać. Jednak sam smak produktu może ulec zmianie. Chodzi o to, żeby nie

16 Np. „War” on food waste can save money and boost profits, Israeli tech firm says, „The Japan Times”, 10.10.2018, https://www.japantimes.co.jp/ news/2018/10/10/business/war-food-waste-can-save-money-boost-profits -israeli-tech-firm-says/\#.XKsqvdgwjcs [dostęp: 10.10.2018].

17 „Przedmiotem niniejszej akcji jest promowanie gospodarki odpadami w zgodzie z naturą i człowiekiem. Sama idea „DO YOU KYOTO?”, to odpowiedzialność za swoje czyny oraz dbanie o otaczające nas środowisko. Wraz z Burmistrzem miasta Kioto pragniemy edukować społeczeństwo oraz kształtować kreatywność dzieci, młodzieży i dorosłych w zakresie ekologii. We wspomnianym konkursie zwracamy mieszkańcom Polski uwagę na ponowne wykorzystanie odpadów, poprzez wykonywanie z nich nowych/ innych rzeczy. Maskotka Eco-Chan to postać reprezentująca ideę upcyclingu, której głowę stanowi zawiązany worek z odpadami oraz pagoda (rodzaj wieży na terenie świątyni). Postać ta obrazuje możliwość koegzystencji odpowiednio zagospodarowanych odpadów oraz zabytków kultury", Do You Kyoto? Czy robisz coś dobrego dla środowiska?, https://ekocykl.org/doyoukyoto/ [dostęp: 10.01.2019]. 
wyrzucać od razu jedzenia, którego nie zjadło się na czas, czyli zmienić rygorystyczne podejście do daty na opakowaniu. Przy okazji proponuje się zrewidowanie zasady zwanej „zasadą jednej trzeciej”. Zgodnie z nią okres od wyprodukowania produktu spożywczego do wyznaczonej daty „sprzedać” dzieli się na trzy krótsze okresy: czas, jaki producenci żywności mają na dostarczenie żywności do sprzedawców detalicznych, okres, w którym detaliści mają sprzedawać produkt i okres zalecany, aby konsumenci spożyli zakupiony produkt. Dostrzega się duży potencjał w zmianie funkcjonowania tych terminów, korzystny dla spożycia produktu przez konsumenta po skróceniu zwłaszcza pierwszego z trzech okresów składowych.

Termin przydatności, a zwłaszcza utrzymanie dobrej jakości produktów „wydłuża” konsumentowi używania właściwych opakowań, przedłużających świeżość warzyw, owoców, mięsa itp. Właściwe przechowywanie to część sukcesu w ograniczeniu marnotrawstwa.

W systemie edukacji ważne jest też proponowanie dzielenia się jedzeniem, którego nie skonsumujemy, z potrzebującymi. W Japonii powstały już jadłodzielnie. Z relacji z ich funkcjonowania wynika, że grupą najczęściej korzystającą z tej formy zaopatrzenia się w żywność są ludzie starsi, samotni, którym nie starcza pieniędzy na zakup odpowiedniej ilości pożywienia. W 2015 r. oszacowano, że 3 mln japońskich dzieci było niedożywionych, żyło poniżej granicy ubóstwa. Stanowi to $13,9 \%$ wszystkich dzieci w tym państwie ${ }^{18}$. Są też ludzie pozbawieni pracy w wyniku choroby czy przypadku losowego, dla których jest to niekiedy jedyny sposób zdobycia dodatkowego pożywienia. W dniu 3 września 2017 r. 36-letnia Yasuko Matsumoto ${ }^{19}$ otworzyła bezpłatny punkt z żywnością w okolicach zachod-

18 Japan throws out 620,000 tons..., op.cit.

19 Urodzona 30 czerwca 1981 r., wychowała się w Tama w Tokio. W listopadzie 2015 r. założyła organizację NPO „Share Mind”. 
niego Tokio (bank żywności). Jest ona prezesem organizacji charytatywnej Share Mind z siedzibą w Tama. Od 2016 r. wraz z grupą współpracowników pozyskuje nadwyżki żywności po to, aby nieodpłatnie podarować je potrzebującym ${ }^{20}$. Otwarty punkt, zwany „Bezpłatnym supermarketem”, skierowany jest głównie do rodzin z dziećmi, osób poszukujących pracy, ludzi schorowanych, okaleczonych i niesprawnych intelektualnie, niemogących podjąć pracy. Według założeń każdy otrzyma tam żywność lub posiłek na miejscu. W chwili otwarcia punkt ten działał tylko w pierwszą niedzielę miesiąca. Przyjmowana w takich miejscach jest żywność o co najmniej 2-miesięcznym terminie przydatności i nierozpakowana. Organizacja ma stronę, na której podany jest kontakt i zasady współpracy. Poszukuje się przede wszystkim żywności, którą można przechować bez lodówek. Brak środków na ciągłe działanie takich punktów pomocowych, to problem dostrzeżony przez innych zwolenników odzyskiwania żywności nadającej się jeszcze do spożycia.

W 2002 r. powstała w Japonii organizacja non-profit będąca pierwszym bankiem żywności w Japonii - Second Harvest $J_{a p a n}^{21}$. W samym 2016 r. zamieniła około 2 tys. ton oddanego jedzenia w 4,7 mln posiłków. Były to produkty pochodzące od supermarketów i rolników. Tygodniowo wydawano 300-400 gorących posiłków osobom będącym w potrzebie. Organizacja oparta była m.in. na pracy wolontariuszy, którzy przygotowują paczki żywnościowe wysyłane do placówek opiekuńczych i organizacji opieki społecznej. Otrzymują je rodziny i dzieci niedożywione. Osobom, które nie mogą osobiście odebrać paczek żywnościowych są one wysyłane. W 2018 r. została jego działalność dofinansowana przez Euroclear Bank, który wybrał

20 Kostenloses Essen: Foodsharing-Supermarkt in Tokyo eröffnet, „Sumikai", https://sumikai.com/nachrichten-aus-japan/kostenloses-essen-foodsharing-supermarkt-in-tokyo-eroeffnet-191126/ [dostęp: 18.04.2019].

21 http://2hj.org/english/support/time/ [dostęp: 18.04.2019]. 
Second Harvest Japan na partnera w działaniach charytatywnych w Japonii ${ }^{22}$.

Inną instytucją jest Food Bank Kansai ${ }^{23}$, organizacja non-profit zbierająca żywność od firm i osób prywatnych i nieodpłatnie dostarczająca ją osobom potrzebującym. Organizacja została założona w 2003 r. przez Amerykanina Bryana Lawrensa. W 2016 r. miał on 85 firm partnerskich. Trafiały do niego produkty, które inaczej wyrzuconoby z powodu: błędów drukarskich na etykiecie, niewłaściwego kształtu lub wagi, uszkodzonych opakowań, w których były przewożone (np. skrzyń), niewłaściwie opisane, z kończącą się datą przydatności, niesprzedane w ciągu dnia, niezjedzone w indywidualnych gospodarstwach a dobre, znajdujące się w nadmiarze owoce i warzywa sezonowe, które by wyrzucono. Żywność przekazywano stąd do instytucji opiekuńczych (świetlice dla dzieci niepełnosprawnych, sierocińce, bezdomni, schroniska dla samotnych matek), jednoosobowych gospodarstw domowych (sieć Kodomo Genki) i stołówek dla dzieci (Kodomo -Shokudo). Stołówki takie zapewniają dzieciom, które pozostają same $\mathrm{w}$ domu podczas pracy rodziców, darmowy lub niskopłatny posiłek. Część żywności przeznaczano na wsparcie osób znajdujących się w nagłej potrzebie, np. z powodu klęski żywiołowej. Bank współpracował w ocenie sytuacji jednoosobowych rodzin (głównie kobiety o dorywczej pracy) z Net Kobe NPO (organizacja wspierająca kobiety i dzieci) i Ikuno Gaukuen (powstała w 2016 r.). Obie organizacje udzielają także szerokiego wsparcia pozażywnościowego. Ta działalność ma pozwolić samotnym matkom na wyjście z izolacji, a udzielone wsparcie na znalezienie stałego źródła dochodu i wyjścia z nędzy. Przytoczone przykłady

22 Euroclear Bank Japan Branch designates 2HJ as Community Charity Partner, 2HJ, http://2hj.org/english/activity/report/jushou/2353.html [dostęp: 26.12.2018].

23 Siedziba w Ashiya w Prefekturze Hyogo, https://www.japanfs.org/en/ news/archives/news_id035694.html [dostęp: 18.04.2019]. 
są jedynie wyimkami wśród organizacji pomagających ubogim i zmarginalizowanym przez życie we współczesnej Japonii. Według Ministerstwa Rolnictwa, Leśnictwa i Rybołówstwa na dzień 31 stycznia 2017 r. w Japonii działało 77 organizacji - banków żywności ${ }^{24}$.

Podejmowane wysiłki, aby zbędna, ale zdatna do spożycia żywność trafiała do potrzebujących, a nie do śmieci lub recyklingu zaowocowały wzrostem pomysłów na „okazyjną” sprzedaż jedzenia ${ }^{25}$. Dlatego powstały aplikacje na telefon, dzięki którym można dowiedzieć się czy restauracja, sklep itp. nie oferują akurat przecenionej żywności. Inicjatorem takiej aplikacji był Sosuke Uemura, prezes Shifft Inc. 5 kwietnia uruchomił on usługę aplikacji na smartfony Reduce Go., która nie jest stworzona dla akcji charytatywnej. Ma ona zarejestrowanym użytkownikom przynieść korzyści ekonomiczne w postaci zysków. Ten kto przecenia żywność zyskuje, podobnie jak odbiorca tańszego towaru. Korzystają z niej restauratorzy, sklepy, bary, piekarnie. Wkrótce po tej firmie podobną aplikację łączącą konsumenta i branżę spożywczą uruchomiło CoCooking Inc. z Tokio, prowadzone przez Kazumę Kawagoe. Na stronie Tabete $^{26}$ konsumenci mogą kupować po znacznie obniżonej cenie posiłki i produkty spożywcze, które w przeciwnym razie zostałyby wyrzucone. Odbiera się je w umówionym miejscu. Co ciekawe, pomysłodawcy nie są zwolennikami darmowego

24 „Mottainai!” Japan Wastes Around 6.5 Million Tons of Food Per Year Society, Nippon. Com., https://www.nippon.com/en/features/h00278/mottainai!-japan-wastes-around-6-5-million-tons-of-food-per-year.html Sep 10, 2018 [dostęp: 14.05.2019].

25 S. Murakami, Tokyo-based startups look to link consumers with restaurants to curb food waste, https://www.japantimes.co.jp/news/2018/05 /04/|national/tokyo-based-startups-look-link-consumers-restaurants-curbfood-waste/\#.XKsrTdgwjcs [dostęp: 12.02.2019].

26 Japan's CoCooking Raises Seed Round To Help Restaurants Sell Excess Food, https://thespoon.tech/japans-cocooking-raises-seed-round-to-helprestaurants-sell-excess-food/ [ dostęp: 3.09.2018]. 
rozdawnictwa. Zwracają uwagę, że organizacje oparte wyłącznie na darowiznach często znajdują się bez środków i zasobów niezbędnych do podtrzymania swojej działalności. Podział zysków osiąganych dzięki korzystaniu z aplikacji wygląda następująco: sklep otrzymuje 65\%, CoCooking otrzymuje 30\%, a reszta zysków jest przekazywana organizacjom charytatywnym, które wspierają japońskie dzieci z rodzin będących w trudnej sytuacji ekonomicznej.

W skali państwa powstają restauracje, w których można zamówić małe porcje. Restauratorzy kierują się zasadą żywienia klienta tak, aby nie wyrzucać resztek. Coraz częściej w Japonii stosuje się w restauracjach zabieranie niezjedzonego posiłku do domu. Jak można wyczytać w mediach, zastosowanie atrakcyjnego pojemnika na wynos pomaga oswoić tę nową modę. Problemem, jak sugerowano, może być mentalność społeczeństwa. Ludzie muszą przywyknąć do tego, że mała porcja czy jedzenie we dwoje to nie wstyd. Nie świadczy to o niskim statusie klienta, tylko o trosce o dobrostan państwa i własny interes z tym związany. W świetle dostępnych informacji wydaje się, że Japończycy nie mają problemu z akceptacją takiej postawy. Częściej żywią niepokój restauratorzy, obawiając się przede wszystkim utraty klienta.

Przejaw troski państwa to także naciski i inspiracje w kierunku udoskonalania sposobów przechowywania żywności. Wspieranie nowoczesnych technologii i producentów je stosujących. Odzyskiwanie tyle żywności ile się da, aby przetworzyć je na produkt mogący być użyty w innej formie. Od 2007 r. systematycznie promuje się firmy, które zajmują się przekształcaniem odpadów w kompost lub paszę dla zwierząt. Promuje się fermy i ogrodnictwa, które decydują się na wykorzystywanie pasz i nawozów pochodzących z recyklingu. Polega to na stymulowaniu przedsiębiorstw handlowych do zakupu i dys- 
trybucji takich produktów ${ }^{27}$. Wspiera się małych lokalnych producentów żywności, aby zaopatrywali najbliższą okolicę we własne produkty i przetwory. Eliminuje to straty podczas transportu. Gwarantuje najlepsza świeżość produktu, co wydłuża czas do spożycia. Stymuluje u kupującego nawyk kupowania małych ilości jedzenia, bo nie musi on tracić czasu na dalekie wyprawy i szukanie po wielu sklepach. Stymuluje także rozwój lokalnego rynku pracy i usług. Jako przykład można podać kooperację sklepów z producentami. Sieć supermarketów Uny Co. Ltd przekazuje odpady spożywcze do firmy recyklingowej Sanko Ltd. Sanko zabiera odpady i produkuje nawóz, który jest następnie wykorzystywany przez rolników (uprawa roślin spożywczych: ryż, soja, warzywa, hodowla ryb, uprawy $\mathrm{w}$ sadownictwie ${ }^{28}$ ). Efekty pracy rolników, rybaków i sadowników są skupowane przez sieć Uny Co. Ltd i wprowadzane do sprzedaży w ich sieciach supermarketów i przez Internet. Tak funkcjonuje pętla recyklingu w praktyce.

Ciekawą propozycją jest także projekt „Tokyo super eco town", którego zarysy przedstawiły władze Tokio w $2001 \mathrm{r}^{29}$ W jego realizację zaangażował się premier Japonii. Ma on doprowadzić do rewitalizacji terenów Tokio. Władze miasta wyznaczyły tereny (określane skrótem TMG), na których ma odbywać się recykling odpadów. Zostały tam ulokowane firmy zajmujące się recyklingiem. Jeżeli odpady zawierają PCB zajmować się będzie ich recyklingiem wyspecjalizowane przedsiębiorstwo - Ja-

27 K. Diep, Food Waste Around the World: Japan; https://theculinologist.wordpress.com/2016/07/07/food-waste-around-the-world-japan/ [dostęp: 3.01.2019].

28 F. Marra, Fighting Food Loss and Food Waste in Japan, M.A. in Japanese Studies - Asian Studies 2011-2013, Leiden University, pdf [dostęp: 10.01.2019].

29 Tokyo Metropolitan Government, Tokyo Super Eco Town Project Outline, http://www.kankyo.metro.tokyo.jp/resource/recycle/super_eco_town/ super_eco_town.files/outline.pdf [dostęp: 10.03.2019]. 
pan Environmental Safety Corporation. Korporacja dysponuje w całym kraju pięcioma centrami utylizacji takich odpadów ${ }^{30}$. Praca z tego rodzaju odpadami regulowana jest przez ustawę o ochronie środowiska oraz o przetwarzaniu odpadów $\mathrm{PCB}^{31}$. W 2002 r. wybrano firmy wykonujące utylizację i recykling odpadów w utworzonej strefie. W 2006 r. rozpoczęto nabór drugiej tury wniosków od firm kooperentów chętnych partycypować w projekcie. Wraz z rozwojem strefy liczbę kooperentów będzie trzeba systematycznie uzupełniać.

Nas interesuje jednak recykling odpadów żywnościowych ${ }^{32}$. Powierzono to zadanie Alfo Co. LDT. Firma ${ }^{33}$ odbiera i suszy odpady żywnościowe, następnie wykorzystuje się je do produkcji składników wykorzystywanych w paszach dla zwierząt (for the pork and poultry industries - przemysł mięsny - tucz świń i drobiu). Wykorzystuje się w recyklingu zaawansowaną technologię "niskotemperaturowego osuszacza próżniowego". Paszę z odpadów można wyprodukować w ten sposób w ok. 90 minut. Dziennie firma mogła przetworzyć 140 ton odpadów żywnościowych. W założeniu w 2006 r. było to ok. 25 ton paszy dziennie. Przetworzeniu na paszę podlegają odpadki kuchenne roślinne i zwierzęce oraz resztki jedzenia odbierane z restauracji, hoteli, supermarketów, firm przetwórstwa, hurtowni itp. Recyklingowi w ramach tego projektu poddano nawet tak trudny odpad jak olej.

30 Zlokalizowane są w: Kitakyushu, Osace, Toyocie, Tokio i Muroran. Toyota, Tokyo, Muroran).

31 Są to np. transformatory wysokiego napięcia, kondensatory wysokiego napięcia, bezpieczniki itp.

32 4.7. Animal Feed from Food Waste i 4.8. Biogas Power Generation from Food Waste, Tokyo Metropolitan Government, Tokyo Super Eco Town Project Outline, http://www.kankyo.metro.tokyo.jp/resource/recycle/super eco_town/super_eco_town.files/outline.pdf, s. 9-10 [dostęp: 10.01.2019].

33 3-2 Jonanjima 3-chome, Ota-ku, Tokio, http://www.tokyoclear.co. Jp. Jonanjima Feed Conversion Center. 
Z tego, co nie może stanowić paszy inna firma wytwarza biogaz i metan (Bioenergia Co. $\mathrm{LDT}^{34}$ ). Przy produkcji używa się systemu fermentacji metanowej. W ten sposób wytwarza się dziennie z ok. 130 ton odpadów żywnościowych, ok. 24 tys. kWh mocy, co zapewnia w przeliczeniu na energię elektryczną, energię dla ok. 2400 gospodarstw domowych. Około 60\% jest sprzedawane zewnętrznej firmie z certyfikatem jako zielona energia. Japonia traktuje to jako wkład w globalne ocieplenie, poprzez wytwarzanie energii elektrycznej z odpadów spożywczych. Szacuje się, że zmniejsza to emisję dwutlenku węgla o 5 tys. ton rocznie.

Powstają ekofarmy, jako spółdzielnie. Przykładem takiej jest Kobe - projekt, w który zaangażowano mieszkańców, organizacje pozarządowe, przedsiębiorstwa i władze lokalne. Farmy kompostują odpady organiczne z magazynów Co-op Kobe i przetwarzają je w nawóz organiczny, wykorzystywany następnie do uprawy roślin w ogrodnictwach detalicznych ${ }^{35}$.

Same firmy produkujące żywność szukają sposobów określania podaży i popytu, aby nie generować zapasów żywności, które nie sprzedane mogą przynieść straty finansowe. Wykorzystuje się w ten sposób np. komunikatory, takie jak Twitter, dla określenia trendów. Niewielu z nas ma świadomość, że znajomość zmian pogody może stymulować produkcję żywności. Pogoda znacznie wpływa na potrzeby zakupowe ludzi. Stowarzyszenie Japan Weather Association oszacowało, że ryzyko związane z pogodą ma wpływ na ponad $30 \%$ gałęzi przemysłu spożywczego. Dzięki technice śledzenia i analizowania warunków pogodowych opracowuje się m.in. dane dotyczące sprzedaży i warun-

34 4-4, Jonanjima 3-chome, Ota-ku, Tokio, http://www.bio-energy.co. Jp. Jonanjima Food Recycling Facility.

35 Global Environment Centre Foundation. 2013. „Cleaner Production Technology Information”, 27.05.2013, http://www.gec.jp/CP_DATA/en_inditech.php?tid=1091 [dostęp: 5.01.2019]. 
kujących ją czynników pogodowych. W ten sposób firmy mogą kształtować nadwyżki w zapasach i zmniejszać produkcję w razie potrzeby. Symulację wykonano dla kilku produktów: zimnego sosu ramen, tofu, kawy i napojów gazowanych z gospodarstw Mizkan, Sagamiya Foods, Nestle Japan i Pokka Sapporo Food \& Beverage i detalistów, np. Lawson. Z tych badań wynika, że firmy są w stanie zmniejszyć marnotrawienie produkowanej przez siebie żywności, np. o 40\% w sosie makaronowym i 30\% $\mathrm{w}$ tofu ${ }^{36}$. Wszystko to opracowano dzięki możliwości zestawienia wzorców pogodowych z nawykami konsumentów. Firmy mają nadzieję, że dzięki dopracowaniu w przyszłości programu będę mieć opłacalny system dostaw żywności, który rozprowadzi odpowiednią ilość żywności wśród ludzi.

Rząd Japonii zaproponował szacowanie określonego typu żywności, produkowanej na okresy popularnych wydarzeń z kalendarza kulturalnego i świąt japońskich, np. grillowany węgorz (unagi ${ }^{37}$ ) na Doyo No Ushi No Hi, bułek sushi Eho - maki na Setsubun czy ciastek świątecznych. W styczniu 2019 r. rząd poprosił operatorów supermarketów i sieci sklepów o przygotowanie i sprzedaż rolek Eho-maki, bez robienia niepotrzebnych zapasów na dużą skalę.

Pod wpływem prowadzonych akcji operatorzy największych sieci sklepów spożywczych w Japonii zadeklarowali, że zaczną zezwalać swoim sklepom franczyzowym na sprzedaż po obniżonych cenach pudełkowych obiadów i produktów spożywczych zbliżających się do końca ich okresu przydatności. Świadczy to o wzrastającej powszechnie świadomości przedsiębiorców i udziałowców, że koszty utylizacji niesprzedanego towaru, to uszczerbek w ich zysku. Przy okazji mogą zrobić coś także dla innych i dla Ziemi.

\footnotetext{
36 K. Diep, Food Waste Around the World: Japan..., op.cit.

37 う ぎ, są to ryby z gatunku węgorzy (Anguillidae i Anguill).
} 
Działania podejmowane przez Japonię wpisują się w ogólnoświatowy trend wprowadzania oszczędności, ochrony środowiska i racjonalizowania konsumpcji we współczesnym świecie. Prowadzone są z poszanowaniem lokalnych tradycji i specyfiki japońskiego społeczeństwa.

\section{Bibliografia}

A ducument concerning "Reducing food loss and waste in Japan", which was used in APEC 2019 Expert Consultation, MAFF, http://www.maff.go.jp/e/policies/env/attach/pdf/ frecycle-5.pdf.

Addressing the nation's food waste problem, „The Japan Times", https://www.japantimes.co.jp/opinion/2019/05/26/ editorials/addressing-nations-food-waste-problem/\#. XX842X8wjcs.

Diep K., Food Waste Around the World: Japan, „The Japan Today", 7.07.2016, https://theculinologist.wordpress. com/2016/07/07/food-waste-around-the-world-japan/.

Do You Kyoto? Czy robisz coś dobrego dla środowiska?, https:// ekocykl.org/doyoukyoto/.

Eco-Japan, Nippon. Com, https://www.nippon.com/en/views/ b00301/.

Euroclear Bank Japan Branch designates 2HJ as Community Charity Partner, 2HJ, http://2hj.org/english/activity/report/ jushou/2353.html.

Food sharing in Tokyo, https://community.tokyocheapo.com/t/ food-sharing-in-tokyo/371.

Food Loss and Waste / Food Recycling System, MAFF, http:// www.maff.go.jp/e/policies/env/frecycle.html.

Forms to be used by Japanese food businesses to report to the Japanese government concerning the amount of food wasted, the amount of food waste used as recyclable food resources, 
and other conditions of the use of food waste as recyclable food resources, MAFF, http://www.maff.go.jp/e/policies/ env/frecycle.html.

Global Environment Centre Foundation. 2013, „Cleaner Production Technology Information", 27.05.2013. http://www. gec.jp/CP_DATA/en_inditech.php?tid=1091.

Guidelines for Measuring the Amount of Food Waste Generated and Food Waste Recycling Rate, MAFF, http://www.maff. go.jp/e/policies/env/attach/pdf/frecycle-2.pdf, marzec 2018. Horiuchi Junko, Japan firms getting serious about food waste, households lag behind, „Kyodo News”, https://english. kyodonews.net/news/2019/05/f35ef52484ee-focus-japan -firms-getting-serious-about-food-waste-households-lag -behind.html.

Japan throws out 620,000 tons of food a year, while 3 mil kids don't have enough to eat, "The Japan Today”, https://japantoday.com/category/features/kuchikomi/Japan-throws-out-620=000-tons-of-food-a-year-while-3-mil -kids-don\%27t-have-enough-to-eat.

Japan's CoCooking Raises Seed Round To Help Restaurants Sell Excess Food, https://thespoon.tech/japans-cocooking -raises-seed-round-to-help-restaurants-sell-excess-food/, 3.09.2018.

Johnston E., For Kyoto, a chance to lead Japan in fight against food loss, „The Japan Times”, 20.10.2018, https://www. japantimes.co.jp/news/2018/10/20/national/kyoto-chance -lead-japan-fight-food-loss/\#.XKsqTdgwjcs.

Marra F., Fighting Food Loss and Food Waste in Japan, „M.A. in Japanese Studies-Asian Studies 2011-2013”, Leiden University, pdf.

Marra F., Food Waste in Japan: How Eco-towns and Recycling Loops are Encouraging Self-Sufficiency, foodtank. The Think Tank for Food, https://foodtank.com/news/2013/11/ 
food-waste-in-japan-how-eco-towns-and-recycling-loops -are-encouraging-self.

Mottainai! What a Waste! Japan staves off the worst of "food waste culture", FAO, http://www.fao.org/save-food/news -and-multimedia/news/newsdetails/ru/c/1036297/.

„Mottainai!” Japan Wastes Around 6.5 Million Tons of Food Per Year Society, Nippon. Com., https://www.nippon.com/en/ features/h00278/mottainai!-japan-wastes-around-6-5-million-tons-of-food-per-year.html, 10.09.2018.

Murakami S., Tokyo-based startups look to link consumers with restaurants to curb food waste, https://www.japantimes.co.jp/ news/2018/05/04/national/tokyo-based-startups-look-linkconsumers-restaurants-curb-food-waste/\#.XKsrTdgwjcs.

Nagoya community effort to recycle food waste wins U.N.-related award, „The Japan Times”, 24.12.2018, https://www.japantimes.co.jp/news/2018/12/24/national/nagoya-community-effort-recycle-food-waste-wins-u-n-related-award/\# . XKsp3Ngwjcs.

Nagoya K., AI could solve Japan's food waste problem, Nikkei Asian Review, http://asia.nikkei.com/magazine/20160428Commodities-crucible/Tech-Science/AI-could-solve-Japan -s-food-waste-problem?page $=1$.

O’Shea K., Organic Food in Japan, Just Japan Stuff, https://justjapanstuff.com/2017/02/11/organic-food-in-japan/.

Projects Commissioned by the Ministry of Agriculture, Forestry and Fisheries (MAFF). Project of Trust Survey of Recycling in Food Industry, etc.(Survey on Methods to Reduce Food Loss and Waste for Sports Events)Report (Executive Summary), marzec 2019, http://www.maff.go.jp/e/policies/env/ attach/pdf/frecycle-4.pdf.

Reducing Food Loss and Waste. "MOTTAINAI” for Foods Once Again, MAFF, sierpień 2017, http://www.maff.go.jp/e/policies/env/attach/pdf/frecycle-3.pdf. 
Regular Reportingin accordance with the Food Waste Recycling Act, MAFF, http://www.maff.go.jp/e/policies/env/attach/ pdf/frecycle-1.pdf, maj 2018.

Sharing food in Japan?, http://jaminjapan.xyz/en/sharing-food-japan-2/.

Stasiak A., Japonia zapowiada walkę z marnowaniem żywności, http://www.polska-azja.pl/japonia-zapowiada-walke-z -marnowaniem-zywnosci/.

Tatebayashi K., Kamiyama Ch., Matsui T., Saito O., Machimura T., Accounting shadow benefits of non-market food through food-sharing networks on Hachijo Island, Japan. „Sustainability Science" 2018, 1-18, Springer Japan KK 2018.

The Ministry of Agriculture, Forestry, and Fisherie of Japan, http://www.maff.go.jp/e/.

Tokyo Metropolitan Government, Tokyo Super Eco Town Project Outline, http://www.kankyo.metro.tokyo.jp/resource/ recycle/super_eco_town/super_eco_town.files/outline.pdf. Vom Kimberly, Kostenloses Essen, Foodsharing-Supermarkt in Tokyo eröffnet, „Sumikai Magazin rund um Japan und Korea", https://sumikai.com/nachrichten-aus-japan/kostenloses-essen-foodsharing-supermarkt-in-tokyo-eroeffnet-191126/, 1.10.2017.

"War" on food waste can save money and boost profits, Israeli tech firm says, „The Japan Times”, 10.10.2018, https://www. japantimes.co.jp/news/2018/10/10/business/war-food-waste-can-save-money-boost-profits-israeli-tech-firm-says/\#. XKsqvdgwjcs.

おわりにーー日本食の現在,[Wnioski - obecny stan japońskiej żywności], http://www.maff.go.jp/j/keikaku/syokubunka/ culture/rekishi.html.

フードバンクとは|食べ物の問題 | Second Harvest, [Co to jest bank żywności ?], http://2hj.org/problem/foodbank/.

NPO Share Mind, https://sharemindip.jimdo.com/about-us/. 


\begin{abstract}
Abstrakt
Marnotrawienie żywności jest coraz poważniejszym problemem na całym świecie. Ograniczenie marnotrawienia żywności jest szczególnie poważnym wyzwaniem dla Japonii, ponieważ polega ona w dużej mierze na imporcie w celu zaspokojenia popytu na żywność. W ostatnich latach problem nadprodukcji i sprzedaży był często podkreślany jako problem w dyskusji na ten temat. Wdrożono prawodawstwo wzywające do większych wysiłków w celu ograniczenia marnotrawienia jadalnej żywności - na każdym etapie od produkcji do konsumpcji. Wymaga od rządu krajowego opracowania podstawowej polityki w celu rozwiązania problemu „utraty żywności” i nakłada na samorządy obowiązek opracowania szczegółowych planów działania. Jednak to restauracje i gospodarstwa domowe są odpowiedzialne za około $66 \%$ wyrzucanych produktów spożywczych.
\end{abstract}

Słowa kluczowe: Japonia, tradycje kulinarne, gospodarka, ochrona środowiska, marnotrawienie żywności

\begin{abstract}
Food waste is an increasingly serious problem worldwide. Cutting back on food waste is a particularly serious challenge for Japan since it relies heavily on imports to meet its food demand. In recent years, the problem of overproduction and sales has often been highlighted as an issue in discussing the issue. Legislation calling for greater efforts to curb the waste of edible food - at every stage from production to consumption - has been enacted. It requires the national government to come up with a basic policy to address the "food loss" problem and makes it mandatory for local governments to craft specific plans of action. But these are restaurants and households that are responsible for some $66 \%$ of discarded food.
\end{abstract}

Keywords: Japan, culinary traditions, economy, environmental protection, Food waste. 